\title{
Vitamin A supplementation during pregnancy for maternal and newborn outcomes (Review)
}

\author{
McCauley ME, van den Broek N, Dou L, Othman M
}

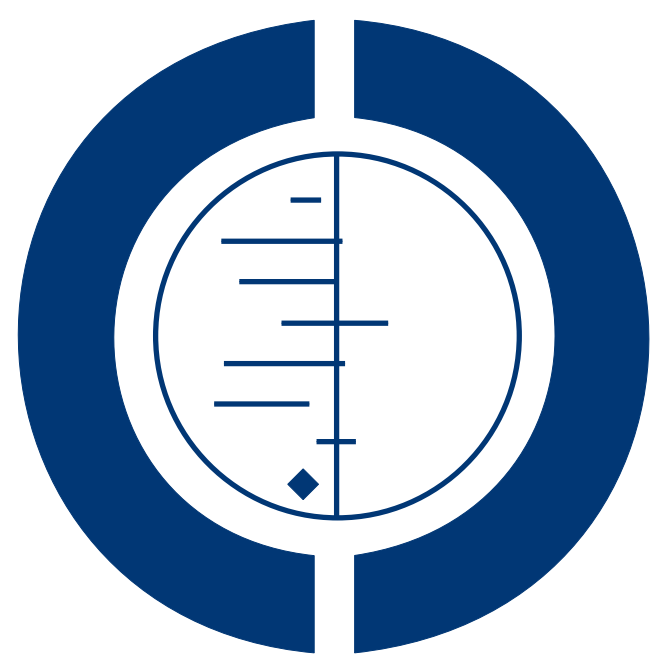

\section{THE COCHRANE COLLABORATION $^{\circledR}$}

This is a reprint of a Cochrane review, prepared and maintained by The Cochrane Collaboration and published in The Cochrane Library 2015, Issue 10

http://www.thecochranelibrary.com

\section{WILEY}

Vitamin A supplementation during pregnancy for maternal and newborn outcomes (Review)

Copyright $\odot 2015$ The Cochrane Collaboration. Published by John Wiley \& Sons, Ltd. 
TABLE OF CONTENTS

HEADER . . . . . . . . . . . . . . . . . . . . . . . . . . . . . . . . . . . . . . . . . . . . . . . . . . . .

ABSTRACT . . . . . . . . . . . . . . . . . . . . . . . . . . . . . . . . . . . . . . . . . . . . . . . . . . .

PLAIN LANGUAGE SUMMARY . . . . . . . . . . . . . . . . . . . . . . . . . . . . . . . . . . . . . . . . . . . . .

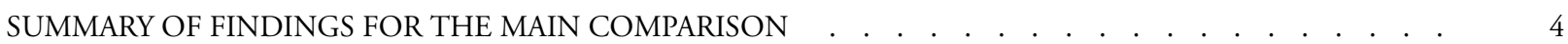

BACKGROUND . . . . . . . . . . . . . . . . . . . . . . . . . . . . . . . . . . . . . . 6

OBJECTIVES . . . . . . . . . . . . . . . . . . . . . . . . . . . . . . . . . . . . . . . . . . . . . .

METHODS . . . . . . . . . . . . . . . . . . . . . . . . . . . . . . . . . . . . . . . .

RESULTS . . . . . . . . . . . . . . . . . . . . . . . . . . . . . . . . . . . . . . . . . . .

Figure 1. . . . . . . . . . . . . . . . . . . . . . . . . . . . . . . . . . . . . . 16

Figure 2. . . . . . . . . . . . . . . . . . . . . . . . . . . . . . . . . . . . . . . . . 17

ADDITIONAL SUMMARY OF FINDINGS . . . . . . . . . . . . . . . . . . . . . . . . . . . . . . 20

DISCUSSION . . . . . . . . . . . . . . . . . . . . . . . . . . . . . . . . . . . . . . . . . . .

AUTHORS' CONCLUSIONS . . . . . . . . . . . . . . . . . . . . . . . . . . . . . . . . . . . . .

ACKNOWLEDGEMENTS . . . . . . . . . . . . . . . . . . . . . . . . . . . . . . . . . . . . . . . . . . .

REFERENCES . . . . . . . . . . . . . . . . . . . . . . . . . . . . . . . . . . . . . . . . .

CHARACTERISTICS OF STUDIES . . . . . . . . . . . . . . . . . . . . . . . . . . . . . . . . . . . . . . . .

DATA AND ANALYSES . . . . . . . . . . . . . . . . . . . . . . . . . . . . . . . . . . . . . . . . . . . . . . . 59

Analysis 1.1. Comparison 1 Vitamin A alone versus placebo or no treatment, Outcome 1 Maternal mortality. . . . 66

Analysis 1.2. Comparison 1 Vitamin A alone versus placebo or no treatment, Outcome 2 Perinatal mortality. . . . 67

Analysis 1.3. Comparison 1 Vitamin A alone versus placebo or no treatment, Outcome 3 Neonatal mortality. . . . 67

Analysis 1.4. Comparison 1 Vitamin A alone versus placebo or no treatment, Outcome 4 Stillbirth. . . . . . . . . 68

Analysis 1.5. Comparison 1 Vitamin A alone versus placebo or no treatment, Outcome 5 Maternal anaemia. $\quad$. $\quad . \quad 68$

Analysis 1.6. Comparison 1 Vitamin A alone versus placebo or no treatment, Outcome 6 Maternal clinical infection. 69

Analysis 1.7. Comparison 1 Vitamin A alone versus placebo or no treatment, Outcome 7 Maternal night blindness. . 70

Analysis 1.8. Comparison 1 Vitamin A alone versus placebo or no treatment, Outcome 8 Preterm birth. . . . . . 71

Analysis 1.9. Comparison 1 Vitamin A alone versus placebo or no treatment, Outcome 9 Neonatal anaemia. $\quad . \quad$. $\quad 72$

Analysis 1.12. Comparison 1 Vitamin A alone versus placebo or no treatment, Outcome 12 Low birthweight. . . . . 73

Analysis 2.6. Comparison 2 Vitamin A alone versus micronutrient supplement without vitamin A, Outcome 6 Maternal clinical infection.

Analysis 3.2. Comparison 3 Vitamin A with other micronutrients versus micronutrient supplements without vitamin A, Outcome 2 Perinatal mortality. . . . . . . . . . . . . . . . . . . . . . . . . . . . . .

Analysis 3.3. Comparison 3 Vitamin A with other micronutrients versus micronutrient supplements without vitamin A, Outcome 3 Neonatal mortality.

Analysis 3.4. Comparison 3 Vitamin A with other micronutrients versus micronutrient supplements without vitamin A, Outcome 4 Stillbirth.

Analysis 3.5. Comparison 3 Vitamin A with other micronutrients versus micronutrient supplements without vitamin A, Outcome 5 Maternal anaemia.

Analysis 3.6. Comparison 3 Vitamin A with other micronutrients versus micronutrient supplements without vitamin A, Outcome 6 Maternal clinical infection.

Analysis 3.8. Comparison 3 Vitamin A with other micronutrients versus micronutrient supplements without vitamin A, Outcome 8 Preterm birth.

Analysis 3.9. Comparison 3 Vitamin A with other micronutrients versus micronutrient supplements without vitamin A, Outcome 9 Neonatal anaemia. . . . . . . . . . . . . . . . . . . . . . . . . . . . . . . . . . . .

Analysis 3.11. Comparison 3 Vitamin A with other micronutrients versus micronutrient supplements without vitamin A, Outcome 11 Congenital malformations.

Analysis 3.12. Comparison 3 Vitamin A with other micronutrients versus micronutrient supplements without vitamin A, Outcome 12 Low birthweight.

Analysis 4.1. Comparison 4 Vitamin A alone versus placebo or no treatment (subgroups), Outcome 1 Perinatal mortality (infant mortality level).

Analysis 4.2. Comparison 4 Vitamin A alone versus placebo or no treatment (subgroups), Outcome 2 Maternal mortality (infant mortality level).

Vitamin A supplementation during pregnancy for maternal and newborn outcomes (Review)

Copyright @ 2015 The Cochrane Collaboration. Published by John Wiley \& Sons, Ltd. 
Analysis 4.3. Comparison 4 Vitamin A alone versus placebo or no treatment (subgroups), Outcome 3 Maternal mortality (maternal mortality level).

Analysis 4.4. Comparison 4 Vitamin A alone versus placebo or no treatment (subgroups), Outcome 4 Perinatal mortality (maternal mortality level).

Analysis 4.5. Comparison 4 Vitamin A alone versus placebo or no treatment (subgroups), Outcome 5 Maternal mortality (prevalence of vitamin A deficiency).

Analysis 4.6. Comparison 4 Vitamin A alone versus placebo or no treatment (subgroups), Outcome 6 Perinatal mortality (prevalence of vitamin A deficiency).

Analysis 4.7. Comparison 4 Vitamin A alone versus placebo or no treatment (subgroups), Outcome 7 Maternal mortality (prevalence of HIV in the general population).

Analysis 4.8. Comparison 4 Vitamin A alone versus placebo or no treatment (subgroups), Outcome 8 Perinatal mortality (prevalence of HIV in the general population).

Analysis 4.9. Comparison 4 Vitamin A alone versus placebo or no treatment (subgroups), Outcome 9 Maternal mortality (dose).

Analysis 4.10. Comparison 4 Vitamin A alone versus placebo or no treatment (subgroups), Outcome 10 Perinatal mortality (dose).

Analysis 4.11. Comparison 4 Vitamin A alone versus placebo or no treatment (subgroups), Outcome 11 Maternal mortality (regimen).

Analysis 4.12. Comparison 4 Vitamin A alone versus placebo or no treatment (subgroups), Outcome 12 Perinatal mortality (regimen).

Analysis 4.13. Comparison 4 Vitamin A alone versus placebo or no treatment (subgroups), Outcome 13 Maternal mortality (duration of intervention).

Analysis 4.15. Comparison 4 Vitamin A alone versus placebo or no treatment (subgroups), Outcome 15 Maternal mortality (trimester of pregnancy).

Analysis 4.16. Comparison 4 Vitamin A alone versus placebo or no treatment (subgroups), Outcome 16 Perinatal mortality (trimester of pregnancy).

Analysis 4.17. Comparison 4 Vitamin A alone versus placebo or no treatment (subgroups), Outcome 17 Maternal mortality (randomisation).

Analysis 4.18. Comparison 4 Vitamin A alone versus placebo or no treatment (subgroups), Outcome 18 Perinatal mortality (randomisation).

Analysis 6.2. Comparison 6 Vitamin A with other micronutrients versus micronutrient supplements without vitamin A (subgroups), Outcome 2 Perinatal mortality (infant mortality level).

Analysis 6.4. Comparison 6 Vitamin A with other micronutrients versus micronutrient supplements without vitamin A (subgroups), Outcome 4 Perinatal mortality (maternal mortality level).

Analysis 6.5. Comparison 6 Vitamin A with other micronutrients versus micronutrient supplements without vitamin A (subgroups), Outcome 5 Maternal mortality (prevalence of vitamin A deficiency).

Analysis 6.6. Comparison 6 Vitamin A with other micronutrients versus micronutrient supplements without vitamin A (subgroups), Outcome 6 Perinatal mortality (prevalence of vitamin A deficiency).

Analysis 6.8. Comparison 6 Vitamin A with other micronutrients versus micronutrient supplements without vitamin A (subgroups), Outcome 8 Perinatal mortality (prevalence of HIV in the general population). . . . . . . . .

Analysis 6.10. Comparison 6 Vitamin A with other micronutrients versus micronutrient supplements without vitamin A (subgroups), Outcome 10 Perinatal mortality (dose).

Analysis 6.12. Comparison 6 Vitamin A with other micronutrients versus micronutrient supplements without vitamin A (subgroups), Outcome 12 Perinatal mortality (regimen). . . . . . . . . . . . . . . . . . . . . . .

Analysis 6.16. Comparison 6 Vitamin A with other micronutrients versus micronutrient supplements without vitamin A (subgroups), Outcome 16 Perinatal mortality (trimester of pregnancy).

Analysis 6.18. Comparison 6 Vitamin A with other micronutrients versus micronutrient supplements without vitamin A (subgroups), Outcome 18 Perinatal mortality (randomisation). . . . . . . . . . . . . . . . . . 106

ADDITIONAL TABLES . . . . . . . . . . . . . . . . . . . . . . . . . . . . . . . . . . 106

WHAT'S NEW . . . . . . . . . . . . . . . . . . . . . . . . . . . . . . . . . . . . . . . . 107

HISTORY . . . . . . . . . . . . . . . . . . . . . . . . . . . . . . . . . . . . . . . . . . . .

CONTRIBUTIONS OF AUTHORS . . . . . . . . . . . . . . . . . . . . . . . . . . . . . . . . . . . . . . . . . . . .

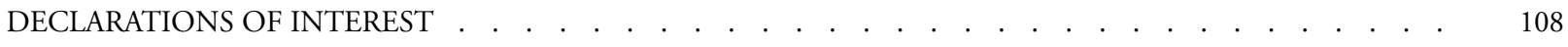

Vitamin A supplementation during pregnancy for maternal and newborn outcomes (Review)

Copyright $\odot 2015$ The Cochrane Collaboration. Published by John Wiley \& Sons, Ltd. 
SOURCES OF SUPPORT . . . . . . . . . . . . . . . . . . . . . . . . . . . . . . . . . . . 108

DIFFERENCES BETWEEN PROTOCOL AND REVIEW . . . . . . . . . . . . . . . . . . . . . . . . . 108

INDEX TERMS . . . . . . . . . . . . . . . . . . . . . . . . . . . . . . . . . . . . 108 


\title{
[Intervention Review]
}

\section{Vitamin A supplementation during pregnancy for maternal and newborn outcomes}

\author{
Mary E McCauley ${ }^{1}$, Nynke van den Broek ${ }^{1}$, Lixia Dou ${ }^{2}$, Mohammad Othman ${ }^{3}$ \\ ${ }^{1}$ Centre for Maternal and Newborn Health, Department of International Public Health, Liverpool School of Tropical Medicine, \\ Liverpool, UK. ${ }^{2}$ Cochrane Pregnancy and Childbirth Group, Department of Women's and Children's Health, The University of \\ Liverpool, Liverpool, UK. ${ }^{3}$ Department of Obstetrics and Gynaecology, Faculty of Medicine, Albaha University, Albaha, Saudi Arabia \\ Contact address: Mary E McCauley, Centre for Maternal and Newborn Health, Department of International Public Health, \\ Liverpool School of Tropical Medicine, Pembroke Place, Liverpool, Merseyside, L3 5QA, UK. mary.mccauley@lstmed.ac.uk. \\ marymccauley@doctors.net.uk.
}

Editorial group: Cochrane Pregnancy and Childbirth Group.

Publication status and date: New search for studies and content updated (no change to conclusions), published in Issue 10, 2015.

Review content assessed as up-to-date: 30 March 2015.

Citation: McCauley ME, van den Broek N, Dou L, Othman M. Vitamin A supplementation during pregnancy for maternal and newborn outcomes. Cochrane Database of Systematic Reviews 2015, Issue 10. Art. No.: CD008666. DOI: 10.1002/14651858.CD008666.pub3.

Copyright (C) 2015 The Cochrane Collaboration. Published by John Wiley \& Sons, Ltd.

\begin{abstract}
A B S T R A C T

\section{Background}

The World Health Organization recommends routine vitamin A supplementation during pregnancy or lactation in areas with endemic vitamin A deficiency (where night blindness occurs), based on the expectation that supplementation will improve maternal and newborn outcomes including mortality, morbidity and prevention of anaemia or infection.
\end{abstract}

\section{Objectives}

To review the effects of supplementation of vitamin A, or one of its derivatives, during pregnancy, alone or in combination with other vitamins and micronutrients, on maternal and newborn clinical outcomes.

\section{Search methods}

We searched the Cochrane Pregnancy and Childbirth Group's Trials Register (30 March 2015) and reference lists of retrieved studies.

\section{Selection criteria}

All randomised or quasi-randomised trials, including cluster-randomised trials, evaluating the effect of vitamin A supplementation in pregnant women.

\section{Data collection and analysis}

Two review authors independently assessed trials for inclusion and risk of bias, extracted data and checked them for accuracy.

\section{Main results}

We reviewed 106 reports of 35 trials, published between 1931 and 2015 . We included 19 trials including over 310,000 women, excluded 15 trials and one is ongoing. Overall, seven trials were judged to be of low risk of bias, three were high risk of bias and for nine it was unclear.

1) Vitamin $A$ alone versus placebo or no treatment

Vitamin A supplementation during pregnancy for maternal and newborn outcomes (Review)

Copyright $\odot 2015$ The Cochrane Collaboration. Published by John Wiley \& Sons, Ltd. 
Overall, when trial results are pooled, vitamin A supplementation does not affect the risk of maternal mortality (risk ratio (RR) 0.88 , 95\% confidence interval (CI) 0.65 to 1.20; four trials Ghana, Nepal, Bangladesh, UK, high quality evidence), perinatal mortality (RR 1.01, 95\% CI 0.95 to 1.07; one study, high quality evidence), neonatal mortality, stillbirth, neonatal anaemia, preterm birth (RR 0.98 , 95\% CI 0.94 to 1.01, five studies, high quality evidence), or the risk of having a low birthweight baby.

Vitamin A supplementation reduces the risk of maternal night blindness (RR 0.79, 95\% CI 0.64 to 0.98 ; two trials). There is evidence that vitamin A supplements may reduce maternal clinical infection (RR 0.45, 95\% CI 0.20 to 0.99, five trials; South Africa, Nepal, Indonesia, Tanzania, UK, low quality evidence) and maternal anaemia (RR 0.64, 95\% CI 0.43 to 0.94; three studies, moderate quality evidence).

\section{2) Vitamin $A$ alone versus micronutrient supplements without vitamin $A$}

Vitamin A alone compared to micronutrient supplements without vitamin A does not decrease maternal clinical infection (RR 0.99, $95 \%$ CI 0.83 to 1.18 , two trials, 591 women). No other primary or secondary outcomes were reported

\section{3) Vitamin A with other micronutrients versus micronutrient supplements without vitamin A}

Vitamin A supplementation (with other micronutrients) does not decrease perinatal mortality (RR 0.51, 95\% CI 0.10 to 2.69 ; one study, low quality evidence), maternal anaemia (RR 0.86, 95\% CI 0.68 to 1.09; three studies, low quality evidence), maternal clinical infection (RR $0.95,95 \%$ CI 0.80 to 1.13 ; $\mathrm{I}^{2}=45 \%$, two studies, low quality evidence) or preterm birth (RR 0.39 , $95 \%$ CI 0.08 to 1.93; one study, low quality evidence).

In HIV-positive women vitamin A supplementation given with other micronutrients was associated with fewer low birthweight babies $(<2.5 \mathrm{~kg})$ in the supplemented group in one study (RR 0.67, 95\% CI 0.47 to 0.96; one study, 594 women).

\section{Authors' conclusions}

The pooled results of three large trials in Nepal, Ghana and Bangladesh (with over 153,500 women) do not currently suggest a role for antenatal vitamin A supplementation to reduce maternal or perinatal mortality. However, the populations studied were probably different with regard to baseline vitamin A status and there were problems with follow-up of women. There is good evidence that antenatal vitamin A supplementation reduces maternal night blindness, maternal anaemia for women who live in areas where vitamin A deficiency is common or who are HIV-positive. In addition the available evidence suggests a reduction in maternal infection, but these data are not of a high quality.

\section{PLAIN LANGUAGE SUMMARY}

\section{Vitamin A supplementation during pregnancy for maternal and newborn health outcomes}

\section{What is the issue?}

Vitamin A is a fat-soluble vitamin found in liver, kidney, eggs, and dairy produce. Low dietary fat intake or intestinal infections may interfere with the absorption of vitamin A. Natural retinoids are required for a wide range of biological processes including vision, immune function, bone metabolism and blood production. In pregnancy, extra vitamin A may be required. Currently, the World Health Organization (WHO) and other international agencies recommend routine vitamin A supplementation during pregnancy or at any time during lactation in areas with endemic vitamin A deficiency (where night blindness occurs).

\section{Why is this important?}

It has been suggested that a low intake of vitamin A may be associated with complications in pregnancy such as death of the mother or baby, increased infections for the mother or baby, low iron level for the mother or baby or having a baby with any of the following complications: early delivery, low birthweight or a congential abnormality.

\section{What evidence did we find?}

This review included 19 studies involving over 310,000 women. Seven trials were conducted in Africa, six in Indonesia, two in Bangladesh, and one each in Nepal, China, India, UK and USA. Most of the trials were conducted in populations considered to be vitamin A deficient (except USA and UK). The overall risk of bias was low to unclear in most of the trials, and the body of evidence was moderate to high quality. The findings indicate that routine supplementation with vitamin A (either alone or in combination with other supplements) during pregnancy did not reduce mother or newborn baby deaths. There is good evidence that antenatal vitamin 
A supplementation does reduce maternal anaemia in women who live in areas where vitamin A deficiency is common or who are HIVpositive. The trials published so far did not report any side effects or adverse events. The available evidence suggests a reduction in maternal infection but these data are not of a high quality and further trials would be needed to confirm or refute this.

\section{What does this mean?}

Taking vitamin A supplements during pregnancy does not help to prevent maternal deaths (related to pregnancy) or perinatal or newborn baby deaths. Taking vitamin A supplements during pregnancy does not help to prevent other problems that can occur such as stillbirth, preterm birth, low birthweight of babies or newborn babies with anaemia. However, the risk of maternal anaemia, maternal infection and maternal night blindness is reduced. 


\section{SUMMARY OF FINDINGSFOR THE MAIN COMPARISON [Explanation]}

\section{Vitamin A alone versus placebo or no treatment}

Patient or population: Pregnant women

Settings: Areas with endemic vitamin A deficiency (inadequate intake)/areas with adequate intake as defined by the WHO global database on vitamin A deficiency

Intervention: Vitamin A alone versus placebo or no treatment

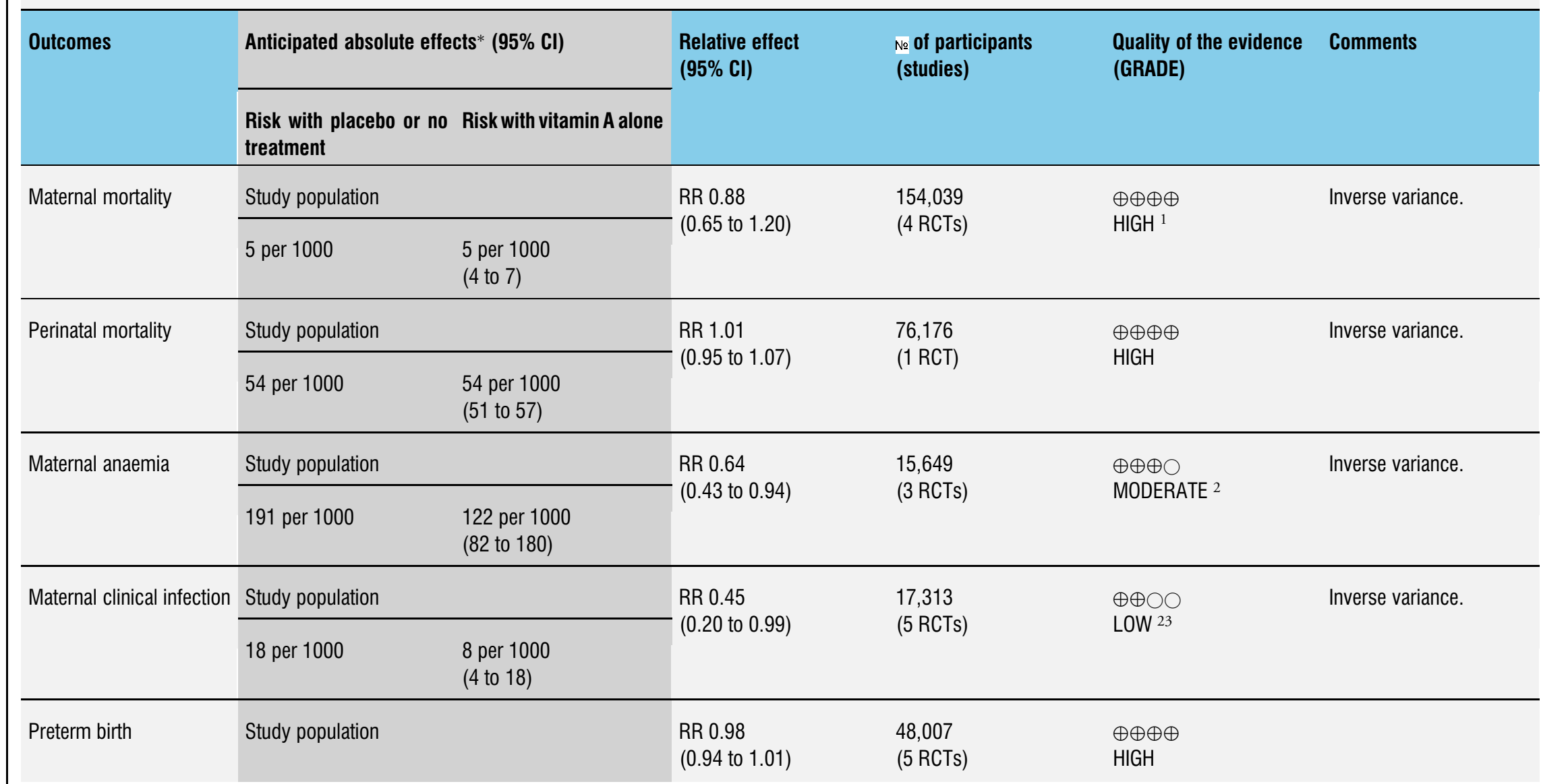




\begin{tabular}{ll}
\hline 249 per 1000 & $\begin{array}{l}244 \text { per } 1000 \\
(234 \text { to } 251)\end{array}$ \\
\hline Moderate & \\
\hline 190 per 1000 & $\begin{array}{l}186 \text { per } 1000 \\
(178 \text { to } 192)\end{array}$
\end{tabular}

${ }^{\star}$ The risk in the intervention group (and its $95 \%$ confidence interval) is based on the assumed risk in the comparison group and the relative effect of the intervention (and its $95 \% \mathrm{Cl}$ ).

Cl: Confidence interval; RR: Risk ratio

\section{GRADE Working Group grades of evidence}

High quality: We are very confident that the true effect lies close to that of the estimate of the effect

Moderate quality: We are moderately confident in the effect estimate: The true effect is likely to be close to the estimate of the effect, but there is a possibility that it is substantially different

Low quality: Our confidence in the effect estimate is limited: The true effect may be substantially different from the estimate of the effect

Very low quality: We have very little confidence in the effect estimate: The true effect is likely to be substantially different from the estimate of effect

${ }^{1}$ The authors considered that the pooled effect estimate was not biased by the design of the studies or their analysis of data. Following

correspondence received from the trialists for Kirkwood 2010, the loss to follow-up for this study was 8\%: the data from this study

are not at risk of attrition bias.

2 Statistical Heterogeneity $\left(1^{2}>60 \%\right)$

${ }^{3}$ Most studies contributing data had design limitations. 


\section{B A C K G R O U N D}

\section{Description of the condition}

\section{Vitamin A general}

Vitamin A is a fat-soluble vitamin that is derived from two sources: preformed retinoids and provitamin carotenoids. Retinoids, such as retinal and retinoic acid, are found in animal sources like liver, kidney, eggs, and dairy produce. Carotenoids like beta-carotene are found in plants such as dark or yellow vegetables and carrots. Carotenoids can be converted to vitamin $\mathrm{A}$ in the liver where vitamin $\mathrm{A}$ is stored. Absorption from plant sources is thought to be low and animal sources (i.e. including dairy products) may be needed to achieve adequate levels (Borel 2005; Tang 2005).

The digestion and absorption of vitamin A is closely associated with lipid absorption. Factors such as low dietary fat intake or intestinal infections may interfere with the absorption of vitamin A (Mahalanabis 1979; Sivakumar 1972).

Natural retinoids are present in all living organisms, either as preformed vitamin $\mathrm{A}$ or as carotenoids, and are required for a vast number of biological processes including vision, gene transcription, immune function, bone metabolism, haematopoiesis, skin health and antioxidant activity (Combs 2008; McGuire 2007). Sufficient stores (in the liver) may be able to maintain a person's requirement for months (FAO and WHO 2002).

In humans, vitamin $\mathrm{A}$ has three active forms (retinal, retinol and retinoic acid), and a storage form (retinyl ester). The absorption of vitamin A depends on the amount of lipids ingested in the diet, with lipids increasing uptake of beta-carotene and vitamin A (Lidén 2006). Beta-carotene can be cleaved into retinoids in the liver and the intestines by enzymes known as carotenoid oxygenases, via two pathways - central or eccentric cleavage. Central cleavage uses beta-carotene-15,15'-monooxygenase (EC 1.14.99.36), whereby beta-carotene is cleaved at its central 15,15'double bond to yield two retinal molecules, which are then converted to two molecules of retinol (vitamin A). Eccentric (or asymmetric) cleavage splits beta-carotene at double bonds other than the central one, yielding beta-apocarotenals of different chain lengths and carotenoic acids, which can then be converted to one molecule of retinol. Under normal physiological conditions, central cleavage is the predominant pathway (Lidén 2006; Moffa 1970; Von Lintig 2000).

Circulating vitamin A is transported in plasma in a 1:1 complex with retinol-binding protein (RBP). RBP is bound to thyroxine binding pre-albumin (TBPA) and this complex functions as a vitamin A transport system. Binding is specific for vitamin A and RBP is the only carrier of retinol in plasma.

The retina and other vitamin A dependent tissues have specific binding sites for RBP and vitamin A. RBP is reduced in proteinuria which may pose a serious threat for transport of retinol to tissues. In conditions like kwashiorkor (protein malnutrition), levels of RBP correct with improved protein nutrition even without vitamin A supplements. RBP is also reduced in zinc deficiency states.

Diseases and conditions that impair the conversion of carotene to vitamin A or reduce the levels of RBP can contribute to the development of vitamin A deficiency as RBP is the main transport protein for vitamin A.

\section{Vitamin A in pregnancy and the newborn}

In pregnancy, some extra vitamin A is required for growth and tissue maintenance in the fetus, for providing fetal reserves, and for maternal metabolism. Pregnant women have a basal requirement of $370 \mathrm{mcg} / \mathrm{d}$ (microgram/day), maximum dose of $3000 \mathrm{mcg} / \mathrm{d}$ and recommended daily allowance (RDA) of $770 \mathrm{mcg} / \mathrm{d}$ (FNB 2001; Stipanuk 2006; WHO 1995). In the non-pregnant woman (or pre-pregnancy), the daily basal requirement is estimated to be $300 \mathrm{mcg} / \mathrm{d}$ with a RDA of $700 \mathrm{mcg} / \mathrm{d}$ (Stipanuk 2006; WHO 1995). Generally, it is considered that liver stores are sufficient to cover these extra needs in non-vitamin A deficient populations. There are potentially adverse effects associated with vitamin A supplementation during pregnancy. In the first 60 days post-conception, retinol is thought to be teratogenic (Rothman 1995; WHO 1998). A relationship has been suggested between the incidence of birth defects and high vitamin A intakes during pregnancy, with an apparent threshold of near 10,000 international units (IU) per day (Mills 1997; Rothman 1995). Increased maternal levels of preformed vitamin A (retinoic acid) have been shown to be associated with miscarriage and with malformations involving the central nervous and cardiac systems (Miller 1998; WHO 1998). A World Health Organization (WHO) expert group consultation concluded that daily doses of up to 10,000 IU (equivalent to 3000 mcg retinol) or 25,000 IU weekly after day 60 are probably safe, especially in areas where vitamin A deficiency is thought to be common (WHO 1998).

The UK National Institute for Health and Clinical Excellence (NICE) guidelines advise that, owing to potential teratogenic effects, women in developed (non vitamin A deficiency) countries should avoid taking vitamin A supplements and liver; in other words, avoiding the intake of vitamin A above $700 \mathrm{mcg}$ per day (NCCWCH 2008).

During pregnancy, vitamin A is transferred to the fetus via the placenta by active mechanisms that maintain the transfer over a wide range of maternal dietary intake. In contrast, during lactation, vitamin A concentration in breast milk is more sensitive to variations in maternal intake (Ross 1994). The estimated requirement for vitamin A in newborn infants up to six months of age is $180 \mathrm{mcg} / \mathrm{d}$, with a safe intake level of $350 \mathrm{mcg} / \mathrm{d}$.

Newborn infants normally have a low level of vitamin A in the liver and they increase these stores in the first few months if the breast milk has adequate levels. Preterm infants have reduced hepatic (liver) stores and lower levels of retinol binding protein (the vitamin A carrier protein) in the plasma compared to babies born 
at term. Insufficient intake and reduced absorption by the immature gut may exacerbate deficiencies in preterm infants (Darlow 2007).

\section{Measurement of vitamin A status}

In the literature on vitamin $\mathrm{A}$, authors have used a variety of different indicators and units of measurement. This can be confusing. In general, the following conversions can be used:

1. serum retinol $1 \mu \mathrm{mol} / \mathrm{L}=28.6 \mu \mathrm{g} / \mathrm{dL}$ or $10 \mu \mathrm{g} / \mathrm{dL}=100$ $\mu \mathrm{g} / \mathrm{L}=0.35 \mu \mathrm{mol} / \mathrm{L}$;

2. for supplement doses $1 \mu \mathrm{g}$ retinol equivalent $=0.00349$ $\mu \mathrm{mol}$ retinol $=3.33 \mathrm{IU}$ vitamin $\mathrm{A}$ or, expressed differently, $1 \mathrm{IU}$ vitamin $\mathrm{A}=0.3 \mu \mathrm{g}$ retinol and $0.00105 \mu \mathrm{mol}$ retinol.

For this review we will endeavour to report whenever known the supplemented dose of vitamin A given in or converted to IU.

There are problems associated with the biochemical assessment of vitamin A deficiency. Serum retinol, because of homeostatic control exerted by the liver, is not a good general indicator of vitamin A status.

Serum retinol levels reflect liver vitamin A stores only when they are severely depleted (less than $0.07 \mu \mathrm{mol} / \mathrm{g}$ liver) or extremely high (more than $1.05 \mu \mathrm{mol} / \mathrm{g}$ liver). Between these extremes, serum retinol is homeostatically controlled and thus not always correlated with vitamin A intake or clinical signs of deficiency. Consequently, serum retinol is not useful in assessing the vitamin A status of individuals. Rather, the distribution of serum retinol values in populations, and the prevalence of individuals with serum retinol values below a given cut off, can provide important information on the vitamin A status of a population and can indicate the severity of vitamin A deficiency as a public health problem (Sommer 1995; WHO 1996). Serum retinol concentrations of 1.05, 0.70 and $0.35 \mu \mathrm{mol} / \mathrm{L}$ have been used in the published literature to indicate inadequate, moderately inadequate and very inadequate liver stores respectively (Underwood 1990).

\section{Clinical manifestations of vitamin A deficiency}

Symptoms of vitamin A deficiency include a variety of eye symptoms, such as night blindness, xerophthalmia (dry eyes, failure to produce tears), keratomalacia (drying and clouding of the cornea with ulceration), Bitot spots (keratin debris in the conjunctiva) and photophobia. Follicular hyperkeratosis (excessive development of keratin in hair follicles), which is also seen with general malnutrition, can be a manifestation of vitamin A deficiency. Ocular changes can be documented quantitatively using a dark adaptation test (e.g. the papillary threshold test - PTT) or using electroretinography. Often change in night blindness is assessed via a simple before (the intervention) and after (the intervention or treatment) questionnaire. In babies born prematurely, symptoms of vitamin A deficiency include bronchopulmonary dysplasia (a form of chronic lung disease).
Night blindness is thought to be one of the first signs of vitamin A deficiency, followed by a diminished ability to fight infections especially respiratory and gastroenteric infections (Sommer 1982; Stephens 1996).

\section{Description of the intervention}

\section{Vitamin A supplementation}

In non-pregnant populations, vitamin A supplementation together with iron has led to improved haemoglobin $(\mathrm{Hb})$ levels in a number of studies (Bloem 1990; Mejia 1988). Fortification of food stuffs with vitamin A in Guatemala (sugar) and Indonesia (monosodium glutamate) was reported to improve ferritin levels (Mejia 1982) and $\mathrm{Hb}$ concentration (Muhilal 1988). Intervention studies in Indonesian girls showed that a multivitamin regimen including vitamin A together with iron supplementation was more effective than iron alone or a multivitamin without vitamin A for improving ferritin levels (Angeles-Agdeppa 1997).

Trials of vitamin A supplementation to reduce the risk of motherto-child transmission of HIV infection in HIV-positive pregnant women and the effect of vitamin A supplementation in the postnatal period are reviewed in separate Cochrane reviews (Oliveira 2010; Wiysonge 2011).

An early study suggested that vitamin A supplementation at time of delivery (oral not intramuscular) may result in an increase of vitamin A in colostrum (Ajans 1965).

A number of studies have assessed the role of vitamin A supplementation on infectious mortality and morbidity in children in developing countries. These have been systematically reviewed (Glasziou 1993). Vitamin A supplementation was associated with a $30 \%$ reduction of death with a larger reduction $(66 \%)$ in children hospitalised with measles. Similar results were found in another review (Fawzi 1993).

\section{How the intervention might work}

\section{Vitamin A deficiency}

For many countries there are still no accurate data on vitamin A status of pregnant women. However, in areas where night blindness is common, vitamin A deficiency is often assumed to be widespread. Vitamin A deficiency is thought to be a significant problem in many developing countries in Africa, South and South-East Asia and areas of Latin America and the Western Pacific (WHO 1995). Reports of population deficiency are often based on the assessment of night blindness and other eye symptoms among pre-school children in various countries. The most obvious deficiency signs are dryness of the conjunctiva and the cornea (xerophthalmia), which can lead to permanent eye damage (McGuire 2007). 
It is also known that a diet devoid of vitamin A results in decreased Hb levels (Hodges 1978). Vitamin A deficiency has been found to co-exist with iron deficiency in a number of developing countries (Karyadi 1996). Several international studies have documented a positive association between serum retinol and $\mathrm{Hb}$ concentration in children (Mejia 1977; Wolde-Gabriel 1993), and pregnant women (Suharno 1992). Anaemia in pregnancy has been associated with vitamin A deficiency (Van den Broek 1998; Van den Broek 2000).

Vitamin A is involved in the growth and differentiation of epithelial tissues and also has a role in immunoprotection (Thurnham 1989; Tomkins 1989). Infections most closely associated with vitamin A deficiency are those in which structure or function of the epithelium may be impaired such as measles, diarrhoea and respiratory disease. Febrile infections are associated with reduced serum levels of retinol binding protein and retinol. This is thought to be an acute phase reaction (Cox 2006; Long 2007). On the other hand, infection and inflammation can depress serum retinol values, as can other micronutrient deficiencies (Thurnham 1989; Tomkins 1989).

Other changes associated with vitamin A deficiency include impaired immunity, and squamous metaplasia of the epithelium lining the upper respiratory passages and urinary bladder leading to a keratinised epithelium. In relation to dentistry, a deficiency in vitamin A leads to enamel hypoplasia (Underwood 1994; WHO 1995).

Finally, there is some evidence that dietary carotenoids have protective function against some human cancers (Rousseau 1992).

\section{Why it is important to do this review}

\section{Vitamin A supplementation in pregnancy}

Currently, the WHO recommends routine vitamin A supplementation during pregnancy or at any time during lactation in areas with endemic vitamin A deficiency (where night blindness occurs) (WHO 1998). The principal forms used as nutritional supplements are vitamin A palmitate (retinyl palmitate) and vitamin A acetate (retinyl acetate), but carotenoids (most commonly betacarotene) and retinoids (retinol, retinal, retinoic acid) can also be used as nutritional supplements (DRI 2001).

Vitamin A supplementation during pregnancy and (extended into) the postnatal period may be expected to affect outcomes such as maternal and newborn mortality, maternal and newborn anaemia or infection or other morbidity and there is also a need to document if supplementation with vitamin $\mathrm{A}$ has been associated with any harmful effects. A number of new trials have been published since the first review on vitamin A supplementation for pregnancy outcomes in 2002 (Van den Broek 2002) and it is therefore important to review all current evidence regarding vitamin A sup- plementation to inform and review the existing recommendations for practice.

\section{O B J E C T I VES}

To review the effectiveness of the supplementation of vitamin A or one of its derivatives during pregnancy, alone or in combination with other vitamins and minerals, on maternal and newborn clinical and laboratory outcomes.

\section{METHODS}

\section{Criteria for considering studies for this review}

\section{Types of studies}

All randomised or quasi-randomised trials, including cluster-randomised trials, evaluating the effect of vitamin A supplementation in pregnant women.

We excluded trials where vitamin A is given only in the postnatal period but included trials where vitamin A was commenced prepregnancy or during pregnancy and continued into the postnatal period.

The outcome 'HIV transmission' was not considered in this review as it is covered in another Cochrane review (Wiysonge 2011), but we included data from randomised controlled trials aimed at preventing vertical transmission if they meet our criteria for inclusion and report obstetric and infant outcomes relevant to our review. In addition, this current review is different from Haider 2008 which reviews the effects of multi-micronutrient supplements which could include vitamin A but does not assess the effect of vitamin A alone.

\section{Types of participants}

Pregnant women receiving vitamin A supplementation either in areas with endemic vitamin A deficiency (inadequate intake) or in areas with adequate intake as defined by the WHO global database on vitamin A deficiency.

\section{Types of interventions}

Vitamin A (or one of its derivatives) supplementation, alone or in combination with other supplements compared with a control group. The control group could be placebo, no treatment or another intervention (for example, iron).

Researchers report vitamin A measurements in different units. Accordingly, we used the following tables for conversions: Table 1; Table 2 . 
Comparisons included: vitamin A (or derivative):

1. alone versus placebo or no treatment;

2. alone versus micronutrient supplements (may include iron or/and folic acid) without vitamin A;

3 . in combination with other micronutrients versus micronutrient supplements without vitamin A.

\section{Types of outcome measures}

The outcomes of this review are maternal and perinatal clinical outcomes.

This review focuses on effects on maternal and newborn mortality and morbidity such as anaemia and infection (but not on HIV which is reviewed elsewhere).

We sought information on the following outcomes for this review.

\section{Primary outcomes}

1. Maternal mortality (defined as the death of a woman while pregnant or within 42 days of termination of pregnancy, irrespective of the duration and site of the pregnancy, from any cause related to, or aggravated by, the pregnancy or its management but not from accidental or incidental causes (ICD-10 2007)).

2. Perinatal mortality (defined as number of stillbirths and deaths in the first week of life per 1000 live births (HAP 2008; PNM 2005)).

\section{Secondary outcomes}

1. Neonatal mortality (defined as the number of deaths during the first 28 completed days of life per 1000 live births in a given year or period (PNM 2005)).

2. Stillbirths (as defined by the trial author).

3. Maternal anaemia (haemoglobin $(\mathrm{Hb})$ less than $11.0 \mathrm{~g} / \mathrm{dL}$ ).

4. Maternal clinical infection (as defined by the investigator).

5. Maternal night blindness (reported or with demonstrable ocular lesion or abnormal adaptation test).

6. Preterm birth (less than $37^{+0}$ weeks gestational age).

7. Neonatal anaemia (as defined by investigator).

8. Neonatal clinical infection (as defined by investigator).

9. Congenital malformations (any reported).

10. Low birthweight (less than $2.5 \mathrm{~kg}$ ).

Where outcomes were not given according to the definitions specified above, we have noted this in the 'Characteristics of included studies' tables and included outcomes in the analyses wherever possible.

\section{Search methods for identification of studies}

The following methods section of this review is based on a standard template used by the Cochrane Pregnancy and Childbirth Group.

\section{Electronic searches}

We searched the Cochrane Pregnancy and Childbirth Group's Trials Register by contacting the Trials Search Co-ordinator (30 March 2015).

The Cochrane Pregnancy and Childbirth Group's Trials Register is maintained by the Trials Search Co-ordinator and contains trials identified from:

1. monthly searches of the Cochrane Central Register of Controlled Trials (CENTRAL);

2. weekly searches of MEDLINE (Ovid);

3. weekly searches of Embase (Ovid);

4. monthly searches of CINAHL (EBSCO);

5. handsearches of 30 journals and the proceedings of major conferences;

6. weekly current awareness alerts for a further 44 journals plus monthly BioMed Central email alerts.

Details of the search strategies for CENTRAL, MEDLINE, Embase and CINAHL, the list of handsearched journals and conference proceedings, and the list of journals reviewed via the current awareness service can be found in the 'Specialized Register' section within the editorial information about the Cochrane Pregnancy and Childbirth Group.

Trials identified through the searching activities described above are each assigned to a review topic (or topics). The Trials Search Co-ordinator searches the register for each review using the topic list rather than keywords.

\section{Searching other resources}

We searched the reference lists of retrieved studies.

We did not apply any language or date restrictions.

\section{Data collection and analysis}

For methods used in the previous version of this review, see van den Broek 2010.

For this update, the following methods were used for assessing the 23 reports that were identified as a result of the updated search.

The following methods section of this review is based on a standard template used by the Cochrane Pregnancy and Childbirth Group.

\section{Selection of studies}

Two review authors independently assessed for inclusion all the potential studies identified as a result of the search strategy. We resolved any disagreement through discussion or, if required, we consulted the third review author.

\section{Data extraction and management}

We designed a form to extract data. For eligible studies, two review authors extracted the data using the agreed form. We resolved 
discrepancies through discussion or, if required, we consulted the third review author. Data were entered into Review Manager software (RevMan 2014) and checked for accuracy.

When information regarding any of the above was unclear, we planned to contact authors of the original reports to provide further details.

\section{Assessment of risk of bias in included studies}

Two review authors independently assessed risk of bias for each study using the criteria outlined in the Cochrane Handbook for Systematic Reviews of Interventions (Higgins 2011). Any disagreement was resolved by discussion or by involving a third assessor.

\section{(I) Random sequence generation (checking for possible selection bias)}

We described for each included study the method used to generate the allocation sequence in sufficient detail to allow an assessment of whether it should produce comparable groups.

We assessed the method as:

- low risk of bias (any truly random process, e.g. random number table; computer random number generator);

- high risk of bias (any non-random process, e.g. odd or even date of birth; hospital or clinic record number);

- unclear risk of bias.

\section{(2) Allocation concealment (checking for possible selection} bias)

We described for each included study the method used to conceal allocation to interventions prior to assignment and assessed whether intervention allocation could have been foreseen in advance of, or during recruitment, or changed after assignment. We assessed the methods as:

- low risk of bias (e.g. telephone or central randomisation; consecutively numbered sealed opaque envelopes);

- high risk of bias (open random allocation; unsealed or nonopaque envelopes, alternation; date of birth);

- unclear risk of bias.

\section{(3.I) Blinding of participants and personnel (checking for possible performance bias)}

We described for each included study the methods used, if any, to blind study participants and personnel from knowledge of which intervention a participant received. We considered that studies were at low risk of bias if they were blinded, or if we judged that the lack of blinding unlikely to affect results. We assessed blinding separately for different outcomes or classes of outcomes.

We assessed the methods as:

- low, high or unclear risk of bias for participants;

- low, high or unclear risk of bias for personnel.
(3.2) Blinding of outcome assessment (checking for possible detection bias)

We described for each included study the methods used, if any, to blind outcome assessors from knowledge of which intervention a participant received. We assessed blinding separately for different outcomes or classes of outcomes.

We assessed methods used to blind outcome assessment as:

- low, high or unclear risk of bias.

(4) Incomplete outcome data (checking for possible attrition bias due to the amount, nature and handling of incomplete outcome data)

We described for each included study, and for each outcome or class of outcomes, the completeness of data including attrition and exclusions from the analysis. We stated whether attrition and exclusions were reported and the numbers included in the analysis at each stage (compared with the total randomised participants), reasons for attrition or exclusion where reported, and whether missing data were balanced across groups or were related to outcomes. Where sufficient information was reported, or could be supplied by the trial authors, we planned to re-include missing data in the analyses which we undertook.

We assessed methods as:

- low risk of bias (e.g. no missing outcome data; missing outcome data balanced across groups);

- high risk of bias (e.g. numbers or reasons for missing data imbalanced across groups; 'as treated' analysis done with substantial departure of intervention received from that assigned at randomisation);

- unclear risk of bias.

\section{(5) Selective reporting (checking for reporting bias)}

We described for each included study how we investigated the possibility of selective outcome reporting bias and what we found. We assessed the methods as:

- low risk of bias (where it is clear that all of the study's prespecified outcomes and all expected outcomes of interest to the review have been reported);

- high risk of bias (where not all the study's pre-specified outcomes have been reported; one or more reported primary outcomes were not pre-specified; outcomes of interest are reported incompletely and so cannot be used; study fails to include results of a key outcome that would have been expected to have been reported);

- unclear risk of bias.

(6) Other bias (checking for bias due to problems not covered by (I) to (5) above)

We described for each included study any important concerns we had about other possible sources of bias. 


\section{(7) Overall risk of bias}

We made explicit judgements about whether studies were at high risk of bias, according to the criteria given in the Handbook ( Higgins 2011). With reference to (1) to (6) above, we planned to assess the likely magnitude and direction of the bias and whether we considered it is likely to impact on the findings. We explored the impact of the level of bias through undertaking sensitivity analyses - see Sensitivity analysis.

\section{Assessment of the quality of the evidence using GRADE}

For this update we assessed the quality of the evidence using the GRADE approach as outlined in the GRADE handbook in order to determine the quality of the body of evidence relating to the following outcomes

1. Maternal mortality

2. Perinatal mortality

3. Preterm birth

4. Maternal anaemia

5. Maternal infection

for the following main comparisons: vitamin A (or derivative):

1. alone versus placebo or no treatment;

2. in combination with other micronutrients versus micronutrient supplements without vitamin A.

We used GRADEpro Guideline Development Tool to import data from Review Manager 5.3 (RevMan 2014) in order to create'Summary of findings' tables. A summary of the intervention effect and a measure of quality for each of the above outcomes was produced using the GRADE approach. The GRADE approach uses five considerations (study limitations, consistency of effect, imprecision, indirectness and publication bias) to assess the quality of the body of evidence for each outcome. The evidence can be downgraded from 'high quality' by one level for serious (or by two levels for very serious) limitations, depending on assessments for risk of bias, indirectness of evidence, serious inconsistency, imprecision of effect estimates or potential publication bias.

\section{Measures of treatment effect}

\section{Dichotomous data}

For dichotomous data, we presented results as summary risk ratio with $95 \%$ confidence intervals.

\section{Continuous data}

No continuous data was analysed in this update. If appropriate, in future updates, we will use the mean difference if outcomes are measured in the same way between trials. We will use the standardised mean difference to combine trials that measure the same outcome, but use different methods.

\section{Unit of analysis issues}

\section{Cluster-randomised trials}

We included cluster-randomised trials in the updated review. One study (West 2011) had reported the results using generalised estimating equation linear regression model and generalised estimating equations binomial regression. These methods had accounted for the clustering in the data. Hence, effect estimates and standard errors were meta-analysed using the generic inverse-variance method in RevMan.

For other studies and outcomes we adjusted their standard error using the methods described in the Handbook [Section 16.3.6] using an estimate of the intra cluster correlation co-efficient (ICC) derived from the trial. We synthesised the relevant information and considered wether it was reasonable to combine the results from both if there was little heterogeneity between the study designs and the interaction between the effect of intervention and the choice of randomisation unit was considered to be unlikely.

We also acknowledged heterogeneity in the randomisation unit and performed a sensitivity analysis to investigate the effects of the randomisation unit.

\section{Other unit of analysis issues}

Multiple-arms trials

Where a trial had multiple intervention arms we avoided 'doubling' of participants by combining groups to create a single pair-wise comparison if possible. Where this was not possible we split the 'shared' groups into two or more groups with smaller sample size and included two or more (reasonably independent) comparisons.

\section{Dealing with missing data}

For included studies, we noted levels of attrition. In future updates, if more eligible studies are included, we will explore the impact of including studies with high levels of missing data in the overall assessment of treatment effect by using sensitivity analysis.

For all outcomes, analyses were carried out, as far as possible, on an intention-to-treat basis, i.e. we attempted to include all participants randomised to each group in the analyses. The denominator for each outcome in each trial was the number randomised minus any participants whose outcomes were known to be missing.

\section{Assessment of heterogeneity}

We assessed statistical heterogeneity in each meta-analysis using the $\mathrm{Tau}^{2}, \mathrm{I}^{2}$ and $\mathrm{Chi}^{2}$ statistics. We regarded heterogeneity as substantial if an $\mathrm{I}^{2}$ was greater than $30 \%$ and either the $\mathrm{Tau}^{2}$ was greater than zero, or there was a low $\mathrm{P}$ value (less than 0.10 ) in the $\mathrm{Chi}^{2}$ test for heterogeneity. If we identified substantial heterogeneity (above 30\%), we planned to explore it by pre-specified subgroup analysis. 


\section{Assessment of reporting biases}

In future updates, if there are 10 or more studies in the metaanalysis we will investigate reporting biases (such as publication bias) using funnel plots. We will assess funnel plot asymmetry visually. If asymmetry is suggested by a visual assessment, we will perform exploratory analyses to investigate it.

\section{Data synthesis}

We carried out statistical analysis using the Review Manager software (RevMan 2014). We used fixed-effect meta-analysis for combining data where it was reasonable to assume that studies were estimating the same underlying treatment effect: i.e. where trials were examining the same intervention, and the trials' populations and methods were judged sufficiently similar.

If there was clinical heterogeneity sufficient to expect that the underlying treatment effects differed between trials, or if substantial statistical heterogeneity was detected, we used random-effects meta-analysis to produce an overall summary, if an average treatment effect across trials was considered clinically meaningful. The random-effects summary was treated as the average of the range of possible treatment effects and we discussed the clinical implications of treatment effects differing between trials. If the average treatment effect was not clinically meaningful, we did not combine trials. If we used random-effects analyses, the results were presented as the average treatment effect with $95 \%$ confidence intervals, and the estimates of $\mathrm{Tau}^{2}$ and $\mathrm{I}^{2}$.

\section{Subgroup analysis and investigation of heterogeneity}

If we identified substantial heterogeneity, we investigated it using subgroup analyses and sensitivity analyses. We considered whether an overall summary was meaningful, and if it was, we used randomeffects analysis to produce it.

Where possible, we carried out the following subgroup analyses.

1. Countries with high versus low infant mortality rates (high infant mortality rate greater than or equal to $30 / 1000$ live births (IMCI- TAG 2008)).

2. Countries with high versus low maternal mortality rates (high maternal mortality rate greater than 100 per 100,000 live births (WHR 2005)).

3. High versus low prevalence of vitamin A deficiency (as defined by WHO for the country or by the investigator).

4. Countries with a low versus high prevalence of HIV in the general population (high-prevalence countries defined as countries with national prevalence that exceeded $3 \%$ of the general population (AIDS Report 2008)).

5. Dose: daily 10,000 IU versus other doses.

6. Regimen: daily versus weekly.

7. Duration of intervention: by number of weeks.

8. Trimester of pregnancy in which supplementation was started (prepregnancy supplementation versus first trimester versus second trimester versus third trimester).
We used only primary outcomes in subgroup analysis.

We assessed subgroup differences by interaction tests available within RevMan (RevMan 2014). We reported the results of subgroup analyses quoting the $\mathrm{Chi}^{2}$ statistic and $\mathrm{P}$ value, and the interaction test $\mathrm{I}^{2}$ value.

\section{Sensitivity analysis}

We planned to carry out out sensitivity analyses to explore the effect of trial quality assessed by concealment of allocation, high attrition rates, or both, with poor quality studies being excluded from the analyses in order to assess whether this makes any difference to the overall result. These sensitivity analyses were not conducted in this update.

\section{R E S U L T S}

\section{Description of studies}

\section{Results of the search}

We reviewed 106 reports of 35 trials, published between 1931 and 2015. We included 19 trials including over 310,000 women, excluded 15 trials and one is ongoing.

\section{Included studies}

For detailed characteristics of the included studies, see Characteristics of included studies.

\section{Study designs}

Of the 19 included trials, three were cluster-randomised ( Kirkwood 2010; West 1999; West 2011), while the rest were based on randomisation of individual women. Only two trials were quasi-randomised (Green 1931; Suprapto 2002).

\section{Settings}

Seven trials were conducted in Africa: three in Malawi (Kumwenda 2002; Semba 2001; van den Broek 2006), one in South Africa (Coutsoudis 1999), two in Ghana (Cox 2005; Kirkwood 2010), and one in Tanzania (Fawzi 1998). Six of the included trials were conducted in Indonesia (Dijkhuizen 2004; Hakimi 1999; Muslimatun 2001; Suharno 1993; Suprapto 2002; Tanumihardjo 2002). Two trials were conducted in Bangladesh (Ahmad 2009; West 2011). One trial was conducted in Nepal (West 1999), one in China (Sun 2010) and one in India (Radhika 2003). 


\section{Population}

All trials were conducted in populations considered to be moderately vitamin A deficient before the relevant trial was commenced except one trial (West 1999) that was conducted in Nepal in which the population was considered to be severely deficient in vitamin A (FAO and WHO 2002; FNB 2001; WHO 1996). Two trials in the USA and UK were conducted in populations that were not a considered vitamin A deficient (Ajans 1965; Green 1931).

\section{Interventions/Controls}

Ten trials used Vitamin A (or one of its derivatives) supplementation alone compared with a control group (Ajans 1965; Coutsoudis 1999; Cox 2005; Green 1931; Kirkwood 2010; Kumwenda 2002; Radhika 2003; van den Broek 2006; West 1999; West 2011).

Five trials used Vitamin A in combination with other supplements compared to a control group (Dijkhuizen 2004; Muslimatun 2001; Semba 2001; Sun 2010; Suprapto 2002).

Four trials investigated both the use of Vitamin A (or one of its derivatives) supplementation alone and Vitamin A in combination with other supplements compared with a control group (Fawzi 1998; Hakimi 1999; Suharno 1993; Tanumihardjo 2002).

The control group included either a placebo, no treatment or another intervention (for example, iron).

Researchers reported vitamin A measurements in different units.

\section{Included studies addressing primary outcomes}

\section{Maternal Mortality}

Four trials reported maternal mortality as a primary outcome. Women of reproductive age were given weekly vitamin A supplements.

Green 1931 is a quasi-randomised trial conducted in the UK. Two hundred and seventy-five women received the vitamin A preparation and 275 women did not, serving as controls . Vitamin A preparation was given as $1 \mathrm{oz}$ of the vitamin preparation radiostoleum, an amount equivalent in vitamins $A$ and $D$ roughly to 30 oz of a good cod-liver oil, and should have been taken commencing one month prior to the calculated day of labour. The first 76 cases prior to June 1929 were given the preparation for only 14 days before delivery (daily). It was, however, continued for the first seven days of the puerperium. Maternal mortality was one of the outcomes assessed.

In the Nepal trial by West 1999, more than 36,800 deliveries were analysed as part of a cluster-randomised field trial conducted in South-East Nepal among a total of 30 village development communities, which are small subdistricts, each of which comprises nine wards. A total of 270 wards were randomised to three groups of 90 each, including 44,646 women of reproductive age receiving a weekly single oral supplement of vitamin A (23 310 IU vitamin
A or $7000 \mathrm{mcg}$ retinol equivalents) or beta carotene ( $42 \mathrm{mcg}$, or $7000 \mathrm{mcg}$ retinol equivalent) or placebo. Pregnant women were eligible to be included in the analysis if they had received supplements for at least five months before conception. The primary outcome of the trial was pregnancy-related and direct mortality occurring up to 12 weeks postpartum and included injury-related deaths.

The trial from Ghana, Kirkwood 2010, is the largest trial with the inclusion of more than 207,000 pregnant women. This was a cluster-randomised trial. All women aged 15 to 45 years living in seven predominantly rural districts in Brong Ahafo Region in Ghana who were capable of giving informed consent and who planned to live in the trial area for at least three months were eligible for enrolment. Implementation was phased by district. The vitamin A capsule consisted of 25000 IU $(7500 \mu \mathrm{g})$ retinol equivalents in soybean oil in a dark red opaque soft gel. The placebo capsule consisted of soybean oil only. The primary outcomes of the trial were pregnancy-related mortality and to compare this with the effect on overall all-cause female mortality. Secondary outcomes were severe maternal morbidity and perinatal and infant mortality. A secondary analysis (Hurt 2013) was conducted of the Kirkwood 2010 trial to determine the effect of weekly vitamin A supplementation on cause-specific mortality in women.

West 2011 conducted a double-blind cluster-randomised placebocontrolled trial in 596 sectors in the rural northwestern district of Gaibandha and Rangpur in Bangladesh between 2001 and 2007. Married women $(\mathrm{n}=125,257)$ underwent five-week surveillance for pregnancy, ascertained by a history of amenorrhoea and confirmed by urine test. Blood samples were obtained from participants in 32 sectors (5\%) for biochemical studies. A total of 59,666 women were eligible for inclusion in this study and were divided into three intervention groups: $7000 \mathrm{ug}$ of retinol equivalent as retinyl palmitate, $42 \mathrm{mg}$ of all-trans beta- carotene, or placebo. One of the primary outcomes was all-cause mortality of women related to pregnancy. Other outcomes included stillbirth and infant mortality to 12 weeks ( 84 days) following the pregnancy outcome and are described under neonatal outcomes.

\section{Perinatal mortality}

None of the included trials investigated perinatal mortality as a primary outcome.

\section{Included studies addressing secondary outcomes}

\section{Maternal anaemia}

A total of nine trials specifically assessed the effect of vitamin A on haemoglobin $(\mathrm{Hb})$ levels. Vitamin A was given during the antenatal period in combination with other micronutrients, generally iron and folic acid. 
There are five studies from Indonesia which assess effect of vitamin A on $\mathrm{Hb}$.

Suharno 1993 included 305 women from 20 rural villages in West Java, 16 to 24 weeks pregnant, with $\mathrm{Hb}$ concentrations between 8.0 and $10.9 \mathrm{~g} / \mathrm{dl}$. Women were assigned to one of four groups to receive daily supplements: one group received vitamin A (2.4 $\mathrm{mg}$ retinol as retinyl palmitate which equates to about $8000 \mathrm{IU}$ vitamin A) and placebo iron tablets; the second group received iron (60 mg elemental iron as ferrous sulphate) and placebo vitamin A; the third group received both the vitamin $A$ and iron supplements (as described in groups one and two); and the fourth group received placebos only.

In Tanumihardjo 2002, pregnant women in the second or early third trimester were recruited from the suburban areas of Bogor in West Java, Indonesia. Ages ranged from 18 to 37 years and parity from 0 to four children. Women were randomly assigned to the following four supplementation groups: placebo, $8.4 \mathrm{~mol}$ (8000 IU) vitamin A as retinyl palmitate with an iron placebo, $1.07 \mathrm{mmol}(60 \mathrm{mg})$ ferrous sulphate with a vitamin A placebo and vitamin A plus iron. The daily supplementation was monitored using a control card and check list by the volunteers who were responsible for administration of the doses.

Suprapto 2002 was a quasi-randomised trial. It took place in the rural area of Banyudono subdistrict, Boyolali regency, Central Java province, Indonesia. All pregnant women who visited the Banyudono health centres' antenatal clinics from July to November 2000 were asked to participate in the study. All pregnant women were numbered and listed. They were then allocated alternately into groups according to their numbers. Group IF ( $n=29)$ received iron-folate tablets $+5 \mathrm{mg}$ glucose (placebo); group IFR $(\mathrm{n}=22)$ received iron-folate tablets $+5 \mathrm{mg}$ riboflavin; group IFA $(\mathrm{n}=29)$ received iron-folate tablets $+2.75 \mathrm{mg}$ retinyl palmitate (equal to 5000 IU vitamin $A)$; and group IFRA $(n=23)$ received iron-folate tablets $+5 \mathrm{mg}$ riboflavin $+2.75 \mathrm{mg}$ retinyl palmitate. These were administered seven days a week for 60 days.

Muslimatun 2001 was carried out in the rural subdistrict of Leuwiliang, West Java, Indonesia. Pregnant women were supplemented once weekly from enrolment until delivery with two tablets each containing $60 \mathrm{mg}$ iron as ferrous sulphate and $250 \mathrm{mg}$ folic acid or with two tablets each containing 2400 retinol equivalents (RE) vitamin $\mathrm{A}$ in addition to the same amount of ferrous sulphate and folic acid.

In Dijkhuizen 2004, all women were recruited before 20 weeks' gestational age from 13 adjacent villages in a rural area in Bogor District, West Java, Indonesia. Each woman was supplemented daily during pregnancy until delivery. All women received iron and folic acid (30 mg iron as ferrous fumarate/ $\mathrm{d}$ and $0.4 \mathrm{mg}$ pteroylglutamic acid/d). In addition, one group of women received -carotene ( $4.5 \mathrm{mg}$ as water-soluble granulate/ $\mathrm{d}$; -carotene group), one group received zinc (30 $\mathrm{mg}$ zinc as sulphate/d; zinc group), one group received -carotene plus zinc ( $4.5 \mathrm{mg}$-carotene and $30 \mathrm{mg}$ zinc/d; -carotene zinc group), and one group received only iron and folic acid (control group).

There are two trials from Malawi where the primary outcome was effect of vitamin $\mathrm{A}$ on $\mathrm{Hb}$.

The Semba 2001 trial was conducted in women attending a teaching hospital antenatal clinic. Pregnant women were given daily supplements of either vitamin A (3000 mcg retinol equivalent, which equals $10,000 \mathrm{IU}$ vitamin $\mathrm{A}$ ), or placebo. All women received daily iron $(30 \mathrm{mg})$ and folate $(400 \mathrm{mcg})$. In addition, all women received two doses of Fansidar during pregnancy as presumptive treatment for malaria. Outcomes were measured at 38 weeks and included $\mathrm{Hb}$ concentration and erythropoietin. Iron status was measured using serum ferritin and markers of inflammation included C-reactive protein (CRP) and alpha-acid glycoprotein. Vitamin A status was measured using serum retinol. Compliance with supplements was assessed via monthly tablet counts. The van den Broek 2006 trial included a representative group of rural women attending antenatal clinic in southern Malawi. Women received daily supplements of either vitamin A 10,000 IU or vitamin A $5000 \mathrm{IU}$, or a placebo. In addition, all women received daily iron supplements $(60 \mathrm{mg}$ elemental iron as ferrous sulphate with $0.25 \mathrm{mg}$ folic acid). Thirty-two per cent of women recruited were HIV-positive. Mean duration of supplementation was 14 weeks. The three main outcome measures were $\mathrm{Hb}$ level, prevalence of anaemia $((\mathrm{Hb})<11.0 \mathrm{~g} / \mathrm{dL})$ and severe anaemia $((\mathrm{Hb})<8.0 \mathrm{~g} / \mathrm{dL})$ after supplementation. Secondary outcomes included vitamin A status, iron status and infection status.

One study from India and one study from China assessed the effect of antenatal supplementation on Hb levels.

Radhika 2003 is a randomised clinical trial of red palm oil supplementation and was conducted in pregnant women attending the outpatient department of Niloufer Hospital, Hyderabad, India, between January 2001 and March 2002. The women in the experimental group received red palm oil providing 2173 to 2307 $\mu \mathrm{g}$ of $\beta$-carotene per day with a dosage schedule of one sachet per day $(8 \mathrm{~mL})$. The women in the control group received one sachet of groundnut oil $(8 \mathrm{~mL})$. A detailed clinical anthropometric and obstetric examination was conducted in all the women at baseline and every two weeks up to 36 weeks and thereafter every week until delivery. All the women received iron folate tablets $(60 \mathrm{mg}$ of iron and $500 \mu \mathrm{g}$ of folic acid) for 100 days and routine prenatal care.

Sun 2010 is a double-blind randomised trial with a two-month duration, conducted in the Shen County in a central rural area of China. In this trial, 186 anaemic pregnant women with a $\mathrm{Hb}$ concentration $>80$ and $<110 \mathrm{~g} / \mathrm{L}$ were allocated to four groups. Group one $(\mathrm{n}=47)$ was supplemented daily with $60 \mathrm{mg}$ iron as ferrous sulphate; Group two $(\mathrm{n}=46)$ with $60 \mathrm{mg}$ and $0.4 \mathrm{mg}$ folic acid; Group three $(\mathrm{n}=46)$ with $60 \mathrm{mg}$ iron, $2.0 \mathrm{mg}$ retinol and $0.4 \mathrm{mg}$ folic acid; and Group four $(\mathrm{n}=47)$ was the placebo control group.

Three studies trials were conducted in HIV-positive pregnant women with the main intent of looking at the effect of vitamin A 
supplementation on mother to child transmission of HIV. These trials also report on other outcomes relevant to this review and are included. In the trial by van den Broek 2006 in rural Malawi, $32 \%$ of all recruited women were HIV-positive but this trial was designed to assess the effect of vitamin $\mathrm{A}$ on $\mathrm{Hb}$ levels and HIV transmission was not measured.

In Kumwenda 2002, the study population consisted of HIV-positive pregnant women of 18 to 28 weeks' gestation who were seen at the antenatal clinic of the Queen Elizabeth Central Hospital (Blantyre, Malawi) from November 1995 through December 1996. All women received orally administered daily doses of iron $(30 \mathrm{mg}$ of elemental iron) and folate $(400 \mathrm{mg}$ ) from the time of study enrolment until delivery. One-half of the women were randomised to receive daily doses of orally administered vitamin A (3 mg retinol equivalent (10,000 IU); the vitamin A group), from the time of study enrolment until delivery.

One trial was conducted in the republic of South Africa: Coutsoudis 1999 is a double-blind randomised trial conducted in King Edward VIII Hospital and McCords Hospital, in Durban, South Africa. HIV-positive women of 28 to 32 weeks' gestation were randomised to receive either placebo or a daily dose of 5000 IU retinyl palmitate and $30 \mathrm{mg}$ beta-carotene during the third trimester of pregnancy and 200,000 IU retinyl palmitate at delivery.

One study from Tanzania (Fawzi 1998), recruited pregnant women between 12 and 27 weeks' gestation who were HIV infected and resident in Dar es Salaam. Women were assigned in a two-by-two factorial design. One thousand and seventy-five women received a daily oral dose of: vitamin A $(30 \mathrm{mg}$ betacarotene plus 5000 IU preformed vitamin A, $\mathrm{n}=269$ ); multivitamins excluding vitamin A $(20 \mathrm{mg} \mathrm{B} 1,20 \mathrm{mg}$ B2, $25 \mathrm{mg}$ B6, $100 \mathrm{mg}$ niacin, $50 \mu \mathrm{g} \mathrm{B} 12,500 \mathrm{mg} \mathrm{C}, 30 \mathrm{mg} \mathrm{E}$, and $0.8 \mathrm{mg}$ folic acid, $\mathrm{n}=269)$; multivitamins including vitamin $A(\mathrm{n}=270)$, all formulated in two tablets; or two tablets of placebo $(n=267)$. Eighty-five per cent of women took the single large dose of the supplement or placebo at delivery; the other $15 \%$ were not given this dose because they delivered at home or at another clinic.

\section{Maternal Infection}

For three trials the main outcome measure was maternal infection. Ajans 1965 conducted a randomised controlled trail in the USA in 44 parturient women who were allotted at random to one of three groups after admission to the delivery suite of the American University Hospital. Group one was the control group that included 18 women who were not given any form of vitamin A therapy prepartum. Group two comprised 15 women who were all given a single intramuscular injection of $600,000 \mathrm{lU}$ of vitamin A palmitate in oil at parturition. Group three was made up of 11 women who were given $600,000 \mathrm{lU}$ of water-dispersible vitamin A palmitate orally shortly before delivery. Four samples of $2 \mathrm{~mL}$ to $3 \mathrm{~mL}$ of colostrum were also collected from each woman: one antepartum sample and three postpartum samples, one on each consecutive day of hospitalisation. The main outcome was levels of maternal infection in breast milk.

Green 1931 described previously, also assessed maternal infection as one of the main outcomes defined as puerperal fever $>38^{\circ} \mathrm{C}$. Hakimi 1999 describe the Zibuvita trial, a double-blind randomised controlled trial conducted in Central Java, Indonesia. One group received vitamin A 2400 retinol equivalent, the second group received zinc $20 \mathrm{mg} /$ day, the third group received both vitamin $\mathrm{A}$ and zinc, while the fourth group received placebo. The main objective was to assess puerperal pyrexia (body temperature $>37.5 \mathrm{C}$ ) and puerperal sepsis (body temperature $>38.0 \mathrm{C}$ ) on at least one day in the postpartum period. Of note, this study information is from a draft of a publication which was not published in any peer review journal. However, two follow-up studies using this original trial data have been published (Prawirohartono 2011; Prawirohartono 2013).

Six follow-up studies of five included trials (Cox 2005; Dijkhuizen 2004; Fawzi 1998; Sun 2010; West 2011) reported on maternal infection as a secondary outcome.

Dijkhuizen 2001 measured maternal puerperal fever as an secondary outcome in a trial described previously, Dijkhuizen 2004. Cox 2005 recruited primigravid pregnant women from antenatal clinics at Nkoranza District Hospital and three rural health clinics in Brong Ahafo region, Central Ghana. Women were randomised to either capsules, which were given weekly and contained 10,000 IU of vitamin A as retinyl palmitate in groundnut oil, plus tocopherol as a preservative from enrolment until six weeks' postpartum, or groundnut oil and tocopherol only in the placebo capsules from enrolment until six weeks' postpartum.

A short two-month duration trial in China (Sun 2010) described previously, assessed the effect of iron combined with retinol supplements in an anaemic pregnant population. The proxy measurements of interleukin 2 (IL-2) level and lymphocyte proliferation were assessed in an attempt to measure the impact on the maternal immune system and as an indirect measure of the maternal ability to combat infection.

Arsenault 2010 assessed a subgroup of the 1078 trial participants in the study of HIV-positive women in Tanzania (Fawzi 1998) for subclinical mastitis, defined as a ratio of the sodium to potassium $(\mathrm{Na}: \mathrm{K})$ breast milk concentration $>0.6$. A total of 1642 breast milk samples were obtained by manual expression from 674 women from delivery and every three months up to two years postpartum. Olofin 2014 also assessed the incidence of malaria in this same trial population (Fawzi 1998). Malaria was defined in two ways: presumptive diagnosis based on a physicians's or nurses's clinical judgement or periodic examination of blood smears for malaria parasites.

Christian 2011 conducted a trial as a substudy of the West 2011 trial and assessed the risk of maternal bacterial vaginosis in the study population. Thirty-three of the total 596 clusters were randomly assigned to the three intervention groups (West 2011) and women were examined for bacterial vaginosis by using self admin- 
istered swabs and the Nugent scoring method in early pregnancy, at 32 weeks' gestation and three months postpartum.

\section{Neonatal outcomes}

Four follow-up studies of four included trials reported neonatal outcomes.

Dijkhuizen 2001 assessed neonatal outcomes in a trial described previously, Dijkhuizen 2004. Outcomes described included preterm delivery, stillbirth, neonatal mortality and low birthweight.

Edmond 2012 conducted a follow-up study of the trial in Ghana (Kirkwood 2010) and assessed the effects of vitamin A supplementation on neonatal mortality (< one month) expressed per 1000 live births amongst other neonatal outcomes.

Christian 2013 conducted a follow-up study of the West 2011 trial to assess the effects of maternal weekly vitamin A and betacarotene supplementation on birthweight, and length of gestation, including preterm birth.

Prawirohartono 2013 is a follow-up study of the Hakimi 1999 trial. Out of 2173 supplement pregnant women, 1956 neonates were assessed to determine whether vitamin A and/or zinc supplement given during pregnancy improved birthweight or neonatal morbidity. Neonatal morbidity included neonatal clinical infection by using measurements of fever, hypothermia, diarrhoea, and vomiting in neonates up to 20 days of life.

\section{Excluded studies}

For detailed characteristics of the excluded trials, see Characteristics of excluded studies.

Of the 15 excluded studies, we excluded two because they used lycopene as the intervention (Banerjee 2009; Sharma 2003). Lycopene lacks beta ion ring (that is present in the beta-carotene), so lycopene cannot form vitamin A and its biological effects are due to mechanisms other than forming vitamin A. One study was excluded as the intervention was unfortified soybean oil and did not include vitamin A or any of its derivatives (Alam 2010). We excluded three studies because they were not randomised trials (Chawla 1995; Howells 1986; Laitinen 2009). We excluded four studies because both arms of the trial contained the same product and so lacked any comparison (Christian 2003; Haskell 2005; Lietz 2001; Roberfroid 2010). We excluded three studies because the intervention only started after delivery (Darboe 2007; Humphrey 2006; Roy 1997). We excluded one study because the only outcome was HIV transmission and although secondary outcomes are relevant to this review, no data are available (Chikobvu 2001). We excluded one study because participants were not pregnant women (Van Vliet 2001).

\section{Risk of bias in included studies}

See Figure 1 and Figure 2.

Figure I. 'Risk of bias' graph: review authors' judgements about each risk of bias item presented as percentages across all included studies.

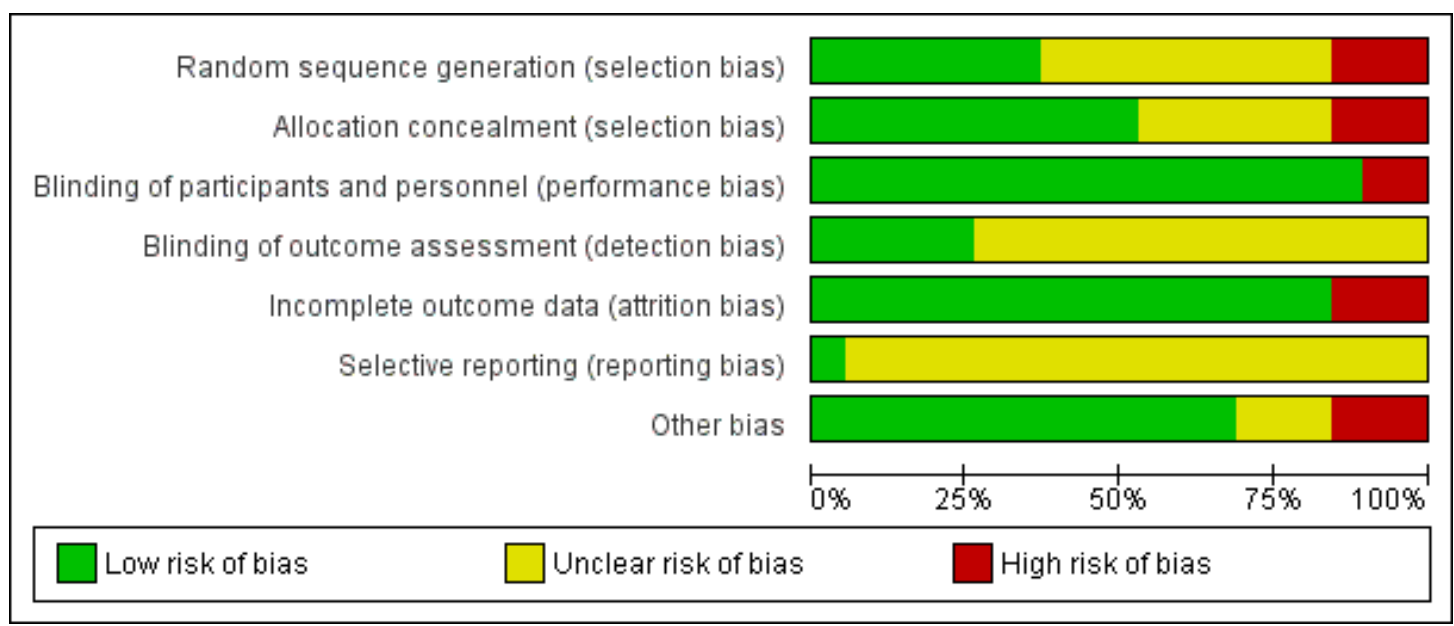

Vitamin A supplementation during pregnancy for maternal and newborn outcomes (Review) 
Figure 2. 'Risk of bias' summary: review authors' judgements about each risk of bias item for each included study.

\begin{tabular}{|c|c|c|c|c|c|c|c|}
\hline & 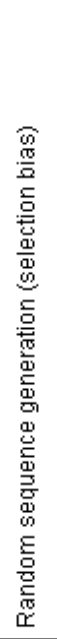 & 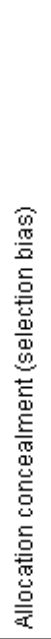 & 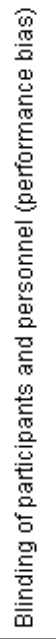 & 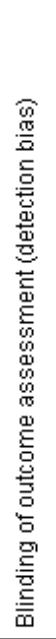 & 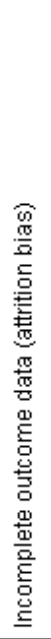 & 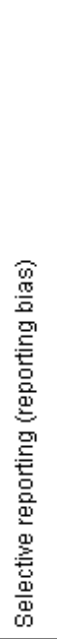 & 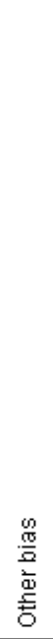 \\
\hline Ajans 1965 & $?$ & $?$ & - & $?$ & $\odot$ & $?$ & - \\
\hline Coutsoudis 1999 & $?$ & $?$ & + & $?$ & $\odot$ & $?$ & + \\
\hline $\operatorname{Cox} 2005$ & ? & $?$ & + & ? & $\odot$ & $?$ & $?$ \\
\hline Dijkhuizen 2004 & $?$ & $\odot$ & $\odot$ & $\odot$ & $\odot$ & $?$ & $\odot$ \\
\hline Fawzi 1998 & $?$ & $\odot$ & $\odot$ & + & + & ? & + \\
\hline Green 1931 & $\Theta$ & $\odot$ & $\Theta$ & $?$ & + & $?$ & + \\
\hline Hakimi 1999 & $\odot$ & $\odot$ & + & $\odot$ & $\Theta$ & $?$ & C \\
\hline Kirkwood 2010 & $\odot$ & $\odot$ & $\odot$ & $?$ & + & ? & + \\
\hline Kumwenda 2002 & + & + & + & $?$ & + & $?$ & + \\
\hline Muslimatun 2001 & $?$ & $?$ & + & $?$ & - & $?$ & + \\
\hline Radhika 2003 & $?$ & $?$ & $\odot$ & $?$ & $\odot$ & $?$ & $\odot$ \\
\hline Semba 2001 & + & $\odot$ & + & ? & $\Theta$ & $?$ & + \\
\hline Suharno 1993 & $?$ & $\odot$ & + & $?$ & + & $?$ & + \\
\hline Sun 2010 & 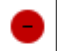 & 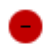 & $\odot$ & $?$ & $\odot$ & $?$ & $?$ \\
\hline Suprapto 2002 & 0 & $\odot$ & $\odot$ & $?$ & $\odot$ & $?$ & 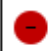 \\
\hline Tanumihardjo 2002 & $?$ & $?$ & $\odot$ & $?$ & $\odot$ & $?$ & $?$ \\
\hline van den Broek 2006 & + & + & + & + & + & $?$ & + \\
\hline West 1999 & 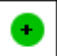 & $\odot$ & + & $?$ & + & $?$ & + \\
\hline West 2011 & + & $\odot$ & + & + & + & + & + \\
\hline
\end{tabular}




\section{Allocation}

Three of the included studies did not report adequate methods for either random sequence generation or allocation concealment (Green 1931; Sun 2010; Suprapto 2002) Six of the included studies were not clear regarding both the allocation concealment and the random sequence generation (Ajans 1965; Coutsoudis 1999; Cox 2005; Muslimatun 2001; Radhika 2003; Tanumihardjo 2002). Three studies were not clear simply with regards to the random sequence generation, but did report adequate allocation concealment (Dijkhuizen 2004; Fawzi 1998; Suharno 1993). The remaining seven trials reported adequate allocation concealment and generation (Hakimi 1999; Kirkwood 2010; Kumwenda 2002; Semba 2001; van den Broek 2006; West 1999; West 2011).

\section{Blinding}

Only two studies reported no blinding of participants and personnel and were unclear regarding the blinding of the outcome (Ajans 1965; Green 1931).

Eleven studies described blinding of participants and personnel, but blinding for outcome assessment was unclear (Coutsoudis 1999; Cox 2005; Kirkwood 2010; Kumwenda 2002; Muslimatun 2001; Radhika 2003; Semba 2001; Suharno 1993; Suprapto 2002; Tanumihardjo 2002; West 1999).

One study Sun 2010 was not clear regarding the blinding of the outcome only but did report adequate blinding of participants and personnel.

The remaining five studies reported adequate double blinding and outcome assessment (Dijkhuizen 2004; Fawzi 1998; Hakimi 1999; van den Broek 2006; West 2011).

\section{Incomplete outcome data}

Three studies were high risk of attrition bias (Hakimi 1999; Muslimatun 2001; Semba 2001), with the remaining 16 included trials adequately addressed the issue of incomplete outcome data and were low risk. the authors of the Kirkwood 2010 trial provided supplementary data to confirm that although $43 \%$ of women migrated out of the trial area and $1 \%$ withdrew consent, the loss to follow-up for pregnancy-related mortality was calculated to be $8 \%$.

\section{Selective reporting}

The protocols of the other included studies were not generally available and accordingly we cannot comment on selective reporting bias except for West 2011 which was free from any selective reporting bias.

\section{Other potential sources of bias}

Three studies were unclear regarding potential sources of bias (Cox 2005; Sun 2010; Tanumihardjo 2002), either because, presence of differences in educational level and gestational age at enrolment (Cox 2005) or the study report is not detailed enough (Tanumihardjo 2002). Three trials had a potential source of bias which were reported (Ajans 1965; Hakimi 1999; Suprapto 2002) The rest of the included trials were free from any potential source of bias.

\section{Effects of interventions}

See: Summary of findings for the main comparison Vitamin A alone versus placebo or no treatment; Summary of findings 2 Combination vitamin A and micronutrients for maternal and newborn mortality and morbidity

\section{Vitamin A alone versus placebo or no treatment}

\section{Primary outcomes}

Vitamin A supplementation does not significantly affect the risk of maternal mortality (risk ratio (RR) $0.88,95 \%$ confidence interval (CI) 0.65 to 1.20 , four studies; $\mathrm{Tau}^{2}=0.04, \mathrm{I}^{2}=50 \%, 101,574$ women; Analysis 1.1) or perinatal mortality (RR 1.01, 95\% CI 0.95 to 1.07 ; one study, 76,176 women; Analysis 1.2).

\section{Secondary outcomes}

Vitamin A supplementation does not significantly affect the risk of neonatal mortality (RR $0.97,95 \%$ CI 0.90 to 1.05 ; three studies , $\mathrm{I}^{2}=23 \%, 89,556$ women; Analysis 1.3), or stillbirth (RR 1.04, 95\% CI 0.98 to 1.10 , two studies, 122,850 women; Analysis 1.4 ). Vitamin A supplementation reduces the risk of maternal anaemia (RR 0.64, 95\% CI 0.43 to 0.94; three studies, $\mathrm{Tau}^{2}=0.08, \mathrm{I}^{2}=$ $68 \%, 3,818$ women; Analysis 1.5), maternal clinical infection (RR $0.45,95 \%$ CI 0.20 to 0.99; five studies, $\mathrm{Tau}^{2}=0.59, \mathrm{I}^{2}=88 \%$, 1,918 women; Analysis 1.6 ), and maternal night blindness (RR $0.79,95 \%$ CI 0.64 to 0.98 ; two studies, 10,608 women; Analysis 1.7).

Vitamin A supplementation does not significantly affect the risk of neonatal anaemia (RR 0.99, 95\% CI 0.92 to 1.08 , one study, 409 women; Analysis 1.9), preterm birth (RR 0.98, 95\% CI 0.94 to 1.01 , five studies, $\mathrm{I}^{2}=29 \%, 40,137$ women; Analysis 1.8 ), or the risk of having a low birthweight baby (RR 1.02, 95\% CI 0.89 to 1.16 , four studies, $\mathrm{Tau}^{2}=0.00, \mathrm{I}^{2}=10 \%, 14,599$ women; Analysis 1.12).

Neonatal clinical infection or congential malformations were not reported in the studies. 
2. Vitamin A alone versus micronutrient supplements without vitamin A

\section{Primary outcomes}

No trial investigated maternal or perinatal mortality as primary outcomes for vitamin A alone versus micronutrient supplements without vitamin A.

\section{Secondary outcomes}

Vitamin A alone compared to micronutrient supplements without vitamin A does not decrease maternal clinical infection (RR 0.99, $95 \%$ CI 0.83 to 1.18 , two studies, $\mathrm{I}^{2}=0 \%, 591$ women) Analysis 2.6. No other secondary outcomes were reported.

\section{Vitamin A with other micronutrients versus micronutrient supplements without vitamin A}

\section{Primary outcomes}

Vitamin A supplementation (with other micronutrients) does not decrease perinatal mortality (RR $0.51,95 \%$ CI 0.10 to 2.69; one study, 179 women) Analysis 3.2. Maternal mortality was not reported.

\section{Secondary outcomes}

Vitamin A supplementation (with other micronutrients) does not decrease maternal anaemia (RR 0.86, 95\% CI 0.68 to 1.09 ; three studies, 706 women) Analysis 3.5, or maternal clinical infection (RR $0.95,95 \%$ CI 0.80 to 1.13 ; $\mathrm{I}^{2}=45 \%$, two studies, 597 women) Analysis 3.6.

Vitamin A supplementation (with other micronutrients) does not decrease neonatal mortality (RR $0.65,95 \%$ CI 0.32 to 1.31 ; one study, 594 women) Analysis 3.3, stillbirth (RR 1.41, 95\% CI 0.57 to 3.47; two studies, 866 women) Analysis 3.4, preterm birth (RR 0.39, 95\% CI 0.08 to 1.93; one study, 136 women) Analysis 3.8, neonatal anaemia (RR $0.75,95 \%$ CI 0.38 to 1.51 ; $\mathrm{Tau}^{2}=0.24$, $\mathrm{I}^{2}=97 \%$; two studies, 1052 women) Analysis 3.9, congential malformations (RR 0.34, 95\% CI 0.04 to 3.18; one study, 179 women) Analysis 3.11, or low birthweight (RR 0.67, 95\% CI 0.47 to 0.96 ; one study, 594 women) Analysis 3.12.

\section{Subgroup analysis}

Only the specified primary outcomes maternal and perinatal mortality were included in the subgroup analysis. Subgroup analysis was by country statistics for vitamin A deficiency (high or low), maternal mortality (high or low), infant morality (high or low), and HIV status (high or low).
All trials investigating the effects on maternal and perinatal mortality were cluster-randomised trials.

\section{Subgroup analysis for vitamin A alone versus placebo or no treatment}

\section{Countries with high versus low infant mortality rates (high infant mortality rate greater than or equal to $30 / 1000$ live births (IMCI- TAG 2008)).}

Perinatal mortality in countries with high infant mortality rates remained unchanged (RR 1.01, 95\% CI 0.95 to 1.07 , one study, 76,176 women) Analysis 4.1. Perinatal mortality was not assessed in countries with low infant mortality rates.

Perinatal mortality in countries with high maternal mortality rates or high prevalence of vitamin A deficiency remained unchanged (RR 0.95 , 95\% CI 0.87 to 1.03 , one study, 73,743 women) Analysis 4.4. No trials reported on perinatal mortality from countries with low maternal mortality rates or countries with low prevalence of vitamin A deficiency.

Countries with high versus low maternal mortality rates (high maternal mortality rate greater than 100 per 100,000 live births (WHR 2005)).

In countries with high maternal mortality, the RR for maternal mortality was 0.91 , (95\% CI 0.76 to 1.08 , four studies, $\mathrm{I}^{2}=55 \%$, 161,240 women) Analysis 4.3 in the overall analysis. There was no interaction between countries with low maternal mortality and countries with high maternal mortality (Test for subgroup differences $\mathrm{P}=0.54, \mathrm{I}^{2}=0 \%$ ). Maternal mortality rate did not change in countries with low infant mortality (RR $0.33,95 \%$ CI 0.01 to 9.44, one study, 550 women) Analysis 4.2.

High versus low prevalence of vitamin A deficiency (as defined by WHO for the country or by the investigator).

Maternal mortality demonstrated no changes in countries with low (RR 0.33 , 95\% CI 0.01 to 8.15; one study, 550 women), or high (RR $0.88,95 \%$ CI 0.63 to 1.23 ; three studies, 160,690 women; $\mathrm{I}^{2}=68 \%$ ) prevalence of vitamin A deficiency Analysis 4.5 .

Perinatal mortality showed no changes in countries with high prevalence of vitamin A deficiency (RR 1.01, 95\% CI 0.95 to 1.07; one study, 76,176 women) Analysis 4.6 .

Countries with a low versus high prevalence of HIV in the general population (high-prevalence countries defined as countries with national prevalence that exceeded $3 \%$ of the general population. 
In countries with low HIV prevalence the RR for maternal mortality was (RR $0.87,95 \%$ CI 0.64 to 1.20 , four studies, $\mathrm{I}^{2}=55 \%$, 161,240 women) Analysis 4.7. The trials in countries with high HIV prevalence did not set out to assess the effect of vitamin A on maternal mortality.

In countries with low HIV prevalence, RR for perinatal mortality was 1.01 (95\% CI 0.95 to 1.07 , one study, 76,176 women) Analysis 4.8. For countries with high HIV prevalence, no trials investigated the effect of vitamin A supplementation to the mother on perinatal mortality.

\section{Dose and regimen of vitamin A}

In relation to the dose, no trials investigated the effect of daily 10,000 IU vitamin A supplementation on maternal mortality, but for other doses the RR for vitamin A supplementation for maternal mortality was (RR $0.88,95 \%$ CI 0.63 to 1.23 , three studies, $\mathrm{I}^{2}=$ $68 \%, 160,690$ women), and for perinatal mortality 1.01 (95\% CI 0.95 to 1.07 , one study, 76,176 women), Analysis 4.9; Analysis 4.10 .

For daily vitamin A supplementation, the RR for maternal mortality was 0.33 (95\% CI 0.01 to 8.15$)$ and weekly supplementation was 0.88 (95\% CI 0.63 to 1.23 , four studies, $I^{2}=55 \%, 161,240$ women), Analysis 4.11. For weekly vitamin A supplement, the RR for perinatal mortality was 1.01 (95\% CI 0.95 to 1.07 , one study, 76,176 women), Analysis 4.12.

\section{Duration of intervention}

There was no difference in the duration of the intervention of vitamin A supplementation on maternal mortality; for one month or less, the RR was 0.33 , 95\% CI 0.01 to 8.15 , one study, 550 women) and more than one month RR was (RR 1.18, 95\% CI 0.83 to 1.68 , one study, 59,666 women), Analysis 4.13. No trial assessed the effect of the duration of intervention with vitamin $\mathrm{A}$ supplementation on perinatal mortality.

\section{Trimester of pregnancy}

There was no trial to assess vitamin A supplementation started in the second trimester on the maternal mortality. However, the RR of vitamin A on maternal mortality started in pre-pregnancy was RR 0.77, (95\% CI 0.50 to 1.17 , two studies, $\mathrm{I}^{2}=71 \%, 101,024$ women), first trimester was RR 1.18, (95\% CI 0.83 to 1.68 , one study, $\mathrm{I}^{2}=0 \%, 59,666$ women), and third trimester was RR 0.33 , (95\% CI 0.01 to 8.15, one study, 550 women), Analysis 4.15. Although, there was no subgroup interaction in Analysis $4.15(\mathrm{P}=$ $\left.0.25, \mathrm{I}^{2}=28.3 \%\right)$.

One trial assessed the vitamin A supplementation started in prepregnancy on perinatal mortality (RR $1.01,95 \%$ CI 0.95 to 1.07 , one study, 76,176 women), Analysis 4.16.

\section{Sensitivity analysis}

\section{Randomisation}

No individual-randomised trial assessed the effect of vitamin A supplementation on maternal and perinatal mortality. For clusterrandomisation trials the RR of vitamin A on was 0.88 , $(95 \% \mathrm{CI}$ 0.63 to 1.23 , three studies, $\mathrm{I}^{2}=68 \%, 160,690$ women) and 1.01 , (95\% CI 0.95 to 1.07 , one study, 76,176 women) respectively, Analysis 4.17; Analysis 4.18.

\section{Subgroup analysis for vitamin A (with other micronutrients) versus micronutrient supplements without vitamin A}

For all subgroup analysis, the RR of vitamin A supplementation (with other micronutrients) on perinatal mortality was 0.51 , (95\% CI 0.10 to 2.69, one study, 179 women) Analysis 6.2. There were no data on maternal mortality for these subgroups. 
ADDITIONALS SMMARY OF F INDINGS [Explanation]

Combination vitamin A and micronutrients for maternal and newborn mortality and morbidity

Patient or population: Pregnant women

Settings: Areas with endemic vitamin A deficiency (inadequate intake)/areas with adequate intake as defined by the WHO global database on vitamin A deficiency

Intervention: Combination vitamin $A$ and micronutrients

Comparison: Other micronutrients

\begin{tabular}{|c|c|c|c|c|c|c|}
\hline \multirow[t]{2}{*}{ Outcomes } & \multicolumn{2}{|c|}{ Anticipated absolute effects* (95\% CI) } & \multirow{2}{*}{$\begin{array}{l}\text { Relative effect } \\
(95 \% \mathrm{CI})\end{array}$} & \multirow{2}{*}{$\begin{array}{l}\text { № of participants } \\
\text { (studies) }\end{array}$} & \multirow{2}{*}{$\begin{array}{l}\text { Quality of the evidence } \\
\text { (GRADE) }\end{array}$} & \multirow[t]{2}{*}{ Comments } \\
\hline & $\begin{array}{l}\text { Risk with mic } \\
\text { supplements } \\
\text { tamin A }\end{array}$ & $\begin{array}{l}\text { Risk with vitamin A with } \\
\text { other micronutrients }\end{array}$ & & & & \\
\hline \multirow[t]{2}{*}{ Maternal mortality } & Study populati & & \multirow[t]{2}{*}{ not estimable } & \multirow[t]{2}{*}{ (0 studies) } & \multirow[t]{2}{*}{ See comment } & \multirow{2}{*}{$\begin{array}{l}\text { No study reported results } \\
\text { for this outcome. }\end{array}$} \\
\hline & not pooled & not pooled & & & & \\
\hline \multirow[t]{4}{*}{ Perinatal mortality } & Study populati & & \multirow{4}{*}{$\begin{array}{l}\text { RR } 0.51 \\
(0.10 \text { to } 2.69)\end{array}$} & \multirow{4}{*}{$\begin{array}{l}179 \\
(1 \mathrm{RCT})\end{array}$} & \multirow{4}{*}{$\begin{array}{l}\oplus \oplus \bigcirc \bigcirc \\
\mathrm{LOW}^{1}\end{array}$} & \\
\hline & 44 per 1000 & $\begin{array}{l}23 \text { per } 1000 \\
(4 \text { to } 120)\end{array}$ & & & & \\
\hline & \multicolumn{2}{|l|}{ Moderate } & & & & \\
\hline & 44 per 1000 & $\begin{array}{l}23 \text { per } 1000 \\
(4 \text { to } 119)\end{array}$ & & & & \\
\hline \multirow[t]{3}{*}{ Maternal anaemia } & \multicolumn{2}{|c|}{ Study population } & \multirow{3}{*}{$\begin{array}{l}\text { RR } 0.86 \\
(0.68 \text { to } 1.09)\end{array}$} & \multirow{3}{*}{$\begin{array}{l}706 \\
\text { (3 RCTs) }\end{array}$} & \multirow{3}{*}{$\begin{array}{l}\oplus \oplus \bigcirc \bigcirc \\
\mathrm{LOW}^{2}\end{array}$} & \\
\hline & 269 per 1000 & $\begin{array}{l}231 \text { per } 1000 \\
\text { (183 to 293) }\end{array}$ & & & & \\
\hline & Moderate & & & & & \\
\hline
\end{tabular}




\begin{tabular}{|c|c|c|c|c|c|}
\hline \multirow{5}{*}{ 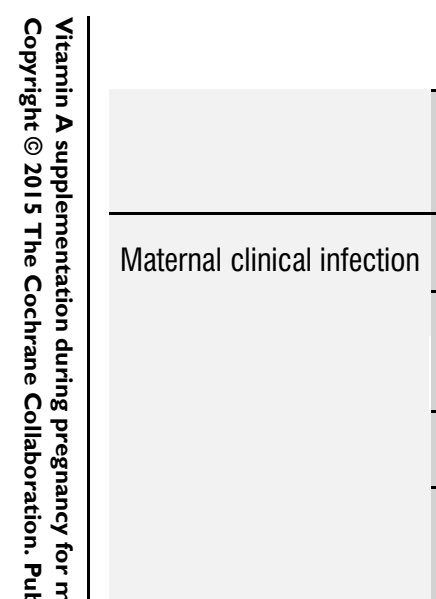 } & 346 per 1000 & $\begin{array}{l}298 \text { per } 1000 \\
\text { (235 to } 377)\end{array}$ & & & \\
\hline & \multicolumn{2}{|c|}{ Study population } & \multirow{4}{*}{$\begin{array}{l}\text { RR } 0.95 \\
-(0.80 \text { to } 1.13)\end{array}$} & \multirow{4}{*}{$\begin{array}{l}597 \\
\text { (2 RCTs) }\end{array}$} & \multirow{4}{*}{$\begin{array}{l}\oplus \oplus \bigcirc \bigcirc \\
\text { LOW }^{2}\end{array}$} \\
\hline & 382 per 1000 & $\begin{array}{l}363 \text { per } 1000 \\
\text { (306 to 432) }\end{array}$ & & & \\
\hline & \multicolumn{2}{|l|}{ Moderate } & & & \\
\hline & 339 per 1000 & $\begin{array}{l}322 \text { per } 1000 \\
\text { (271 to } 383)\end{array}$ & & & \\
\hline \multirow[t]{4}{*}{ Preterm birth } & \multicolumn{2}{|c|}{ Study population } & \multirow{4}{*}{$\begin{array}{l}\text { RR } 0.39 \\
(0.08 \text { to } 1.93)\end{array}$} & \multirow{4}{*}{$\begin{array}{l}136 \\
(1 \mathrm{RCT})\end{array}$} & \multirow{4}{*}{$\begin{array}{l}\oplus \oplus \bigcirc \bigcirc \\
\text { LOW }^{2}\end{array}$} \\
\hline & 75 per 1000 & $\begin{array}{l}29 \text { per } 1000 \\
\text { (6 to 144) }\end{array}$ & & & \\
\hline & \multicolumn{2}{|l|}{ Moderate } & & & \\
\hline & 75 per 1000 & $\begin{array}{l}29 \text { per } 1000 \\
(6 \text { to } 144)\end{array}$ & & & \\
\hline
\end{tabular}

${ }^{\star}$ The risk in the intervention group (and its $95 \%$ confidence interval) is based on the assumed risk in the comparison group and the relative effect of the intervention (and its $95 \% \mathrm{Cl}$ ).

CI: Confidence interval; RR: Risk ratio

\section{GRADE Working Group grades of evidence}

High quality: We are very confident that the true effect lies close to that of the estimate of the effect

Moderate quality: We are moderately confident in the effect estimate: The true effect is likely to be close to the estimate of the effect, but there is a possibility that it is substantially different

Low quality: Our confidence in the effect estimate is limited: The true effect may be substantially different from the estimate of the effect

Very low quality: We have very little confidence in the effect estimate: The true effect is likely to be substantially different from the estimate of effect

${ }^{1}$ Wide confidence interval crossing the line of no effect, few events \& small sample size

${ }^{2}$ Wide confidence interval crossing the line of no effect \& small sample size. 


\section{DISCUSSION}

\section{Summary of main results}

This review investigates the effectiveness of vitamin A supplementation during pregnancy, alone or in combination with other micronutrients, on maternal and newborn clinical outcomes.

Nineteen trials are included in this review out of a total of 35 trials. In countries where night blindness is reported, maternal night blindness is significantly improved with vitamin A supplementation.

Overall, the analysis shows that there is no evidence that vitamin A supplementation to women of reproductive age or during pregnancy decreases maternal mortality. The three largest studies from Nepal, Ghana and Bangladesh specifically assessed the effect on maternal mortality with over 153,500 women included. Vitamin A deficiency is considered to be endemic in Nepal and night blindness is commonly reported. The main trial from Nepal by West 1999 reported a substantial reduction in pregnancy-related mortality (including injuries) with most of the mortality contributing to the difference between supplementation and placebo groups occurring in death from injury, chronic illness and uncertain cause of death, which was difficult to explain. Two subsequent large studies, both conducted in countries with moderate vitamin A deficiency (Ghana and Bangladesh), did not show an effect of vitamin A supplementation on maternal mortality.

In vitamin A deficient populations and HIV-positive women, vitamin A supplementation reduces maternal anaemia and there is evidence that vitamin A supplements alone may reduce maternal clinical infection.

Several trials specifically assessed the effect of vitamin A supplementation during the antenatal period on maternal anaemia. Vitamin A was given together with other micronutrients, principally iron and folic acid. The Malawi study reported no effect of vitamin $\mathrm{A}$ in addition to iron supplementation on haemoglobin $(\mathrm{Hb})$ levels. Assessment of vitamin A status revealed the women were generally vitamin A replete. The other three studies were from countries where vitamin A deficiency is considered to be endemic (Indonesia and Nepal), and from Tanzania, where the population studied were all HIV-positive women. For the three studies included in the meta-analysis, for a total of almost 2500 pregnant women, maternal anaemia $(\mathrm{Hb}<11.0 \mathrm{~g} / \mathrm{dL})$ was found to be reduced.

Five studies measured maternal infection after supplementation with vitamin $A$ in just under 1800 women. It was noted that the criteria for the outcome 'infection' varied between the studies. We note that one study included in the analysis is from a draft of a publication which was not published in any peer review journal. In one trial, the proxy measurements of interleukin 2 (IL-2) level and lymphocyte proliferation were used to as an indirect measure of the maternal ability to combat infection. The most significant study included in the meta-analysis was conducted in the 1930s
(Green 1931) and there are questions related to the accuracy of the design of this study. Also, it has not been possible to calculate the exact dosage of vitamin A given (in the form of radiostoleum). In addition, it must be noted that one of the three studies was in HIV-positive women, who may have a different overall risk of infection compared to non-HIV-positive women.

Of the included trials, 15 were designed to measure the effect of vitamin A supplementation during pregnancy on maternal mortality or maternal anaemia or maternal infection. Other maternal and neonatal clinical outcomes were also determined in the studies but not as primary outcomes. Three trials were designed to assess the effect of vitamin A on mother to child transmission of HIV. We have included these because the secondary outcomes are relevant to this review.

No studies of supplementation in the antenatal period were specifically designed to assess neonatal outcomes, but where these were reported we have included them in the analyses. For studies reporting these outcomes, vitamin A supplementation alone does not affect the risk of perinatal mortality or stillbirth or neonatal mortality separately. Similarly, analysis of available data shows no effect on preterm birth or low birthweight. There were no reported side effects or adverse events in any of the trials. One study did report on congential abnormalities but the effect was not significant. For one study supplementing vitamin A together with other micronutrients (versus other micronutrients in control group) in HIV-positive women, the risk of low birthweight was found to reduced.

The trials are from a variety of countries, including high-, middle- and low-income countries, with large differences between the countries with regard to baseline maternal and perinatal mortality as well as baseline vitamin A status and prevalence of anaemia of the populations studied. In some studies vitamin A status of the trial population was assessed specifically at baseline (by serum retinol levels or using the more accurate modified relative dose response test), whereas in other studies this was not done.

It was difficult to compare the results of supplementation with vitamin A (or derivatives) on maternal and newborn health outcomes, especially where these outcomes were differently defined in the different studies. For example, maternal clinical infection was variously defined as temperature above 37 or 38 degrees Celsius at different times during pregnancy and the postnatal period (e.g. 12 weeks antenatal or one week or three months postnatal); or infectious morbidity was defined by recorded diagnosis (gastroenteritis, sepsis, respiratory infection, etc). In one trial, the proxy measurements of interleukin 2 (IL-2) level and lymphocyte proliferation were used as an indirect measure of the maternal ability to combat infection. The data from this trial were continuous, and could not be combined with other studies with dichotomous outcome data and hence this study did not contribute any data to the review results.

Maternal anaemia was more consistently defined $(\mathrm{Hb}<11.0 \mathrm{~g} / \mathrm{dL}$, $\mathrm{Hb}<10.0 \mathrm{~g} / \mathrm{dL}$ ). However, one study from Malawi and one from 
China reported change in $\mathrm{Hb}$ rather than percentage of women not anaemic and thus we have not included it in the meta-analysis. The dose of vitamin A given, in combination with additional micronutrients and the duration of supplementation differed in the trials and varied between 5000 IU and 10,000 IU for daily doses, around 200,000 IU vitamin A for weekly supplementation and 200,000 IU vitamin A at time of delivery.

There were no differences in outcomes for any of the subgroup analyses performed.

\section{Overall completeness and applicability of evidence}

The three cluster-randomised trials with a large number of participants were included in the meta-analysis and increased the accuracy and reliability of the evidence produced. Added to that, the different populations studied by different included randomised clinical trials amplified the applicability of the evidence produced. Most of the specified outcomes were reported by some of the included trials but the different trials were not designed to measure the same primary outcomes and many of the specified secondary outcomes were either not reported and/or defined differently in the different country settings. The underlying baseline statistics for maternal mortality, perinatal mortality and vitamin A status of pregnant women were not available for the specific population studies, and country estimates were therefore used in most cases.

\section{Quality of the evidence}

In the majority of studies, adequate methods of allocation concealment were described; only three trials described inadequate methods (Green 1931; Sun 2010; Suprapto 2002). Green 1931 and Suprapto 2002 used an alternation method for the allocation generation and concealment; marking each first woman as a participant and the next woman due to deliver as the control. Suharno 1993 did not report how the allocation was generated or concealed. In Sun 2010 women were randomised in order of enrolment. In the case of blinding, all trials included were double blinded except Ajans 1965 and Green 1931, both of which did not use any intervention in the control group. Three clinical trials included lost more than $20 \%$ of the participants (Hakimi 1999; Muslimatun 2001; Semba 2001); these clinical trials were conducted in rural areas with participants moving in and out of the study area. None of the included trials were stopped early. Accordingly, none of the included trials suffered any limitation at the design or implementation level. Furthermore, all the included trials directly compared the effects of vitamin A supplementation on the mother and baby.

Heterogenity between trials in the meta-analysis was minimal $(0 \%$ to $40 \%$ ). Added to that, the precision of the results can be consid- ered good, with narrow confidence intervals in most cases except for the subgroup analyses.

The overall risk of bias is low to unclear for most of the studies. For comparison vitamin A alone versus placebo or no treatment, the quality of the evidence as assessed using GRADE was high for maternal mortality, perinatal mortality, and preterm birth, moderate for maternal anaemia and low for maternal clinical infection (Summary of findings for the main comparison). Reasons for downgrading the evidence include statistical heterogeneity and design limitations. For combination vitamin A and micronutrients, due to wide confidence interval crossing the line of no effect, few events and small sample size, all the outcomes were rated as low quality of the evidence (Summary of findings 2).

\section{Potential biases in the review process}

We acknowledge that there was the potential for bias at all stages in the reviewing process. We attempted to minimise bias in a number of ways; for example, two review authors independently carried out data extraction and assessed risk of bias. However, we acknowledge that such assessments involve subjective judgments, and another review team may not have agreed with all of our decisions.

\section{Agreements and disagreements with other studies or reviews}

The trials included in this review were carefully planned and executed.

The absence of an effect on stillbirth rate, neonatal mortality, or perinatal mortality accords with the findings of the two large cluster trials (Cox 2005; Kirkwood 2010).

It has been suggested that vitamin A supplementation, especially in the postpartum period, will reduce the incidence of sepsis. In the trials reviewed, maternal clinical infection was assessed in a number of ways and there is evidence to suggest that vitamin A could have a significant effect on maternal infection.

Maternal anaemia evidence is of high quality with data to support that supplementation with vitamin A reduces anaemia in vitamin A deficient and HIV-positive women.

There are no reports of side effects or adverse events in the trials published so far.

\section{A U THORS' CONCLUSIONS}

\section{Implications for practice}

Overall, the findings of this review do not currently support a role for antenatal vitamin A supplementation to reduce maternal or perinatal mortality. There is, however, evidence that antenatal 
vitamin A supplementation (in addition to iron and folic acid) reduces maternal anaemia in populations that are vitamin A deficient, and in HIV-positive pregnant women. Although the available evidence suggests a reduction in maternal infection when vitamin A is given antenatally or around the time of delivery, the data are not of a high quality and further evidence is needed to explore the effect of antenatal vitamin A supplementation on maternal infection in the antenatal and postnatal periods. The effect of vitamin A is likely to depend on whether the population who receive supplements are vitamin A deficient or not.

\section{Implications for research}

Results of 19 trials to assess effect of vitamin A supplementation during pregnancy are presented in this review. The three main outcomes examined are maternal mortality, maternal anaemia and maternal infection.

It must be said that for any of these individual outcomes there were between two and four trials that could be included in a metaanalysis and even within this group of trials there was significant difference in population with regard to vitamin A status, baseline anaemia and infection prevalence and maternal mortality ratio.

It seems unlikely that vitamin A supplementation per se contributes directly to reducing maternal mortality. The evidence that this might be possible originally came from the trial in Nepal where vitamin A deficiency is common but reduction in deaths was not in the category of direct maternal deaths. In Ghana and Bangladesh this is less likely as women are moderately vitamin A deficient and supplementation did not reduce mortality. In the study from Ghana there was a substantial number of women lost to followup. In all three trials, (Ghana and Nepal and Bangladesh) results are in the same direction (a reduction in maternal mortality). The trials from Ghana and Bangladesh showed non-significant results. In Ghana, $43 \%$ of women migrated outside the study area and $1 \%$ withdrew consent. These women contributed to the final analysis either by completing a pregnancy before they migrated or contributed data to the analysis of all-cause female mortality by contributing person time to the denominator of this analysis. Loss to follow-up for pregnancy-related mortality was subsequently calculated to be $8 \%$ (supplementary information provided by authors). For Nepal, the reduction in deaths is difficult to explain with biological plausibility, but it was a significant reduction. The baseline vitamin A status in each of these trials was not assessed. Vitamin A deficiency in Nepal is considered to be severe, whereas for Ghana and Bangladesh this is considered to be moderate. For populations with no or less deficiency in vitamin A, supplementation is likely to be less effective.
It would seem that if any new trials are designed, it will be crucially important to assess baseline vitamin A status as well as accurate cause of maternal (and neonatal) death and to ensure follow-up of women is possible. In resource-poor settings where maternal mortality is highest and research most needed, this will also be most difficult to ensure.

Further high-quality evidence on whether vitamin A can reduce infection including maternal sepsis is needed.

To improve haemoglobin $(\mathrm{Hb})$, vitamin A supplementation in addition to iron and folic acid is beneficial in women who are vitamin A deficient or HIV-positive. The optimal dose of vitamin A, length of supplementation and the maximum expected increase in $\mathrm{Hb}$ have not been established. Also effect change will depend on baseline degree of anaemia and vitamin A deficiency, and this requires further study.

It was noted that there are differences between the trials with regard to the dose of vitamin A given, the combination with additional micronutrients and the duration of supplementation. In addition, baseline assessments of vitamin A status are often not available even outside the study population, methods of assessment vary and comparisons are therefore very difficult to make. For future studies it is recommended that these are designed to take account of these limitations. It would also be helpful if neonatal outcomes are measured according to international criteria so that studies can be compared.

\section{ACKNOWLEDGEMENTS}

Lisa Hurt, on behalf of the ObaapaVitA trial team, for providing additional data about the Kirkwood 2010 trial.

We thank Erika Ota for her help with the 2015 update. Erika Ota's work was financially supported by the UNDP/UNFPA/UNICEF/ WHO/World Bank Special Programme of Research, Development and Research Training in Human Reproduction (HRP), Department of Reproductive Health and Research (RHR), World Health Organization. The named authors alone are responsible for the views expressed in this publication.

This project was supported by the National Institute for Health Research, via Cochrane Infrastructure funding to Cochrane Pregnancy and Childbirth. The views and opinions expressed therein are those of the authors and do not necessarily reflect those of the Systematic Reviews Programme, NIHR, NHS or the Department of Health. 


\section{R E F E R E N C E S}

\section{References to studies included in this review}

Ajans 1965 \{published data only\}

Ajans ZA, Sarrif A, Husbands M. Influence of vitamin A on human colostrum and early milk. American Journal of Clinical Nutrition 1965;17:139-42.

Coutsoudis 1999 \{published data only\} Coutsoudis A, Moodley D, Pillay K, Harrigan R, Stone C, Moodley J, et al. Effects of vitamin A supplementation on viral load in HIV-1 infected pregnant women. Journal of Acquired Immune Deficiency Syndromes and Human Retrovirology 1997;15(1):86-7.

* Coutsoudis A, Pillay K, Spooner E, Kuhn L, Coovadia HM. Randomized trial testing the effect of vitamin A supplementation on pregnancy outcomes and early motherto-child HIV-1 transmission in Durban, South Africa. AIDS 1999;13(12):1517-24.

Filteau SM, Rollins NC, Coutsoudis A, Sullivan KR, Willumsen JF, Tomkins AM. The effect of antenatal vitamin $\mathrm{A}$ and beta-carotene supplementation on gut integrity of infants of HIV-infected South African women. Journal of Pediatric Gastroenterology and Nutrition 2001;32(4): 464-70.

Kennedy CM, Coutsoudis A, Kuhn L, Pillay K, Mburu A, Stein Z, et al. Randomized controlled trial assessing the effect of vitamin A supplementation on maternal morbidity during pregnancy and postpartum among HIV-infected women. Journal of Acquired Immune Deficiency Syndromes 2000;24(1):37-44.

Kennedy-Oji C, Coutsoudis A, Kuhn L, Pillay K, Mburu A, Stein Z, et al. Effects of vitamin A supplementation during pregnancy and early lactation on body weight of South African HIV-infected women. Journal of Health, Population \& Nutrition 2001;19(3):167-76.

Kuhn L, Coutsoudis A, Trabattoni D, Archary D, Rossi T, Segat L, et al. Synergy between mannose-binding lectin gene polymorphisms and supplementation with vitamin A influences susceptibility to HIV infection in infants born to HIV-positive mothers. American Journal of Clinical Nutrition 2006;84(3):610-5.

Cox 2005 \{published data only\}

Cox SE, Arthur P, Kirkwood BR, Yeboah-Antwi K, Riley EM. Vitamin A supplementation increases ratios of proinflammatory to anti-inflammatory cytokine responses in pregnancy and lactation. Clinical \& Experimental Immunology 2006;144(3):392-400.

* Cox SE, Staalsoe T, Arthur P, Bulmer JN, Tagbor H, Hviid $\mathrm{L}$, et al. Maternal vitamin A supplementation and immunity to malaria in pregnancy in Ghanaian primigravids. Tropical Medicine \& International Health 2005;10(12):1286-97.

Dijkhuizen 2004 \{published data only\}

Dijkhuizen MA. Vitamin A, Iron and Zinc Deficiency in Indonesia. Micronutrient Interactions and Effects of Supplementation [thesis]. Wageningen University, 2001. * Dijkhuizen MA, Wieringa FT, West CE, Muhilal.
Zinc plus beta-carotene supplementation of pregnant women is superior to beta-carotene supplementation alone in improving vitamin A status in both mothers and infants. American Journal of Clinical Nutrition 2004;80(5): 1299-307.

Wieringa FT, Dijkhuizen MA, Muhilal, Van der Meer JW. Maternal micronutrient supplementation with zinc and beta-carotene affects morbidity and immune function of infants during the first 6 months of life. European Journal of Clinical Nutrition 2010;64(10):1072-9.

Fawzi 1998 \{published data only\}

Arsenault JE, Aboud S, Manji KP, Fawzi WW, Villamor E. Vitamin supplementation increases risk of subclinical mastitis in HIV-infected women. Journal of Nutrition 2010; 140(10):1788-92.

Baylin A, Villamor E, Rifai N, Msamanga G, Fawzi WW. Effect of vitamin supplementation to HIV-infected pregnant women on the micronutrient status of their infants. European Journal of Clinical Nutrition 2005;59(8): 960-8.

Fawzi W, Msamanga G, Antelman G, Xu C, Hertzmark E, Spiegelman D, et al. Effect of prenatal vitamin supplementation on lower-genital levels of HIV type 1 and interleukin type 1 beta at 36 weeks of gestation. Clinical Infectious Diseases 2004;38(5):716-22.

Fawzi WW, Msamanga G, Hunter D, Urassa E, Renjifo B, Mwakagile D, et al. Randomized trial of vitamin supplements in relation to vertical transmission of HIV-1 in Tanzania. Journal of Acquired Immune Deficiency Syndromes 2000;23(3):246-54.

Fawzi WW, Msamanga GI, Hunter D, Renjifo B, Antelman G, Bang H, et al. Randomized trial of vitamin supplements in relation to transmission of HIV-1 through breastfeeding and early child mortality. AIDS (London, England) 2002;16 (14):1935-44.

Fawzi WW, Msamanga GI, Kupka R, Spiegelman D, Villamor E, Mugusi F, et al. Multivitamin supplementation improves hematologic status in HIV-infected women and their children in Tanzania. American Journal of Clinical Nutrition 2007;85(5):1335-43.

Fawzi WW, Msamanga GI, Spiegelman D, Urassa EJ, Hunter DJ. Rationale and design of the Tanzania Vitamin and HIV Infection Trial. Controlled Clinical Trials 1999;20 (1):75-90.

* Fawzi WW, Msamanga GI, Spiegelman D, Urassa EJ, McGrath N, Mwakagile D, et al. Randomised trial of effects of vitamin supplements on pregnancy outcomes and $\mathrm{T}$ cell counts in HIV-1-infected women in Tanzania. Lancet 1998;351(9114):1477-82.

Fawzi WW, Msamanga GI, Spiegelman D, Wei R, Kapiga $S$, Villamor E, et al. A randomized trial of multivitamin supplements and HIV disease progression and mortality. New England Journal of Medicine 2004;351(1):23-32. Fawzi WW, Msamanga GI, Wei R, Spiegelman D, Antelman G, Villamor E, et al. Effect of providing vitamin 
supplements to human immunodeficiency virus-infected, lactating mothers on the child's morbidity and cd $4+$ cell counts. Clinical Infectious Diseases 2003;36(8):1053-62. Kawai K, Kupka R, Mugusi F, Aboud S, Okuma J, Villamor $\mathrm{E}$, et al. A randomized trial to determine the optimal dosage of multivitamin supplements to reduce adverse pregnancy outcomes among HIV-infected women in Tanzania. American Journal of Clinical Nutrition 2010;91(2):391-7. Kawai K, Msamanga G, Manji K, Villamor E, Bosch RJ, Hertzmark E, et al. Sex differences in the effects of maternal vitamin supplements on mortality and morbidity among children born to HIV-infected women in Tanzania. British Journal of Nutrition 2010;103(12):1784-91.

Kupka R, Msamanga GI, Spiegelman D, Morris S, Mugusi F, Hunter DJ, et al. Selenium status is associated with accelerated HIV disease progression among HIV-1-infected pregnant women in Tanzania. Journal of Nutrition 2004; 134(10):2556-60.

McGrath N, Bellinger D, Robins J, Msamanga GI, Tronick E, Fawzi WW. Effect of maternal multivitamin supplementation on the mental and psychomotor development of children who are born to HIV-1-infected mothers in Tanzania. Pediatrics 2006;117(2):216-25. Merchant AT, Msamanga G, Villamor E, Saathoff E, O'Brien M, Hertzmark E, et al. Multivitamin supplementation of HIV-positive women during pregnancy reduces hypertension. Journal of Nutrition 2005;135(7): 1776-81.

Olofin IO, Spiegelman D, Aboud S, Duggan C, Danaei G, Fawzi WW. Supplementation with multivitamins and vitamin $A$ and incidence of malaria among HIV-infected Tanzanian women. Journal of Acquired Immune Deficiency Syndromes 2014;67(Suppl 4):S173-8.

Smith Fawzi MC, Kaaya SF, Mbwambo J, Msamanga GI, Antelman G, Wei R, et al. Multivitamin supplementation in HIV-positive pregnant women: impact on depression and quality of life in a resource-poor setting. HIV Medicine 2007;8(4):203-12.

Villamor E, Koulinska IN, Aboud S, Murrin C, Bosch RJ, Manji KP, et al. Effect of vitamin supplements on HIV shedding in breast milk. American Journal of Clinical Nutrition 2010;92(4):881-6.

Villamor E, Msamanga G, Saathoff E, Fataki M, Manji K, Fawzi WW. Effects of maternal vitamin supplements on malaria in children born to HIV-infected women. American Journal of Tropical Medicine and Hygiene 2007;76 (6):1066-71.

Villamor E, Msamanga G, Saathoff E, Manji K, Fawzi WW. Effect of vitamin supplements on the incidence of malaria among children born to HIV-infected Women. FASEB Journal 2006;20(4 Pt 1):A125.

Villamor E, Saathoff E, Bosch RJ, Hertzmark E, Baylin A, Manji K, et al. Vitamin supplementation of HIV-infected women improves postnatal child growth. American Journal of Clinical Nutrition 2005;81(4):880-8.

Villamor E, Saathoff E, Manji K, Msamanga G, Hunter DJ, Fawzi WW. Vitamin supplements, socioeconomic status, and morbidity events as predictors of wasting in HIV-infected women from Tanzania. American Journal of Clinical Nutrition 2005;82(4):857-65.

Webb AL, Aboud S, Furtado J, Murrin C, Campos H, Fawzi WW, et al. Effect of vitamin supplementation on breast milk concentrations of retinol, carotenoids and tocopherols in HIV-infected Tanzanian women. European Journal of Clinical Nutrition 2009;63(3):332-9.

Green 1931 \{published data only\}

Green HN, Pindar D, Davis G, Mellanby E. Diet as a prophylactic agent against puerperal sepsis. British Medical Journal 1931;2:595-8.

\section{Hakimi 1999 \{unpublished data only\}}

* Hakimi M, Dibley M. ZIBUVITA trial: impact of vitamin $A$ and zinc supplementation in pregnancy on maternal post partum infections. Personal communication 1999. Prawirohartono EP, Nystrom L, Ivarsson A, Stenlund $\mathrm{H}$, Lind $\mathrm{T}$. The impact of prenatal vitamin $\mathrm{A}$ and zinc supplementation on growth of children up to 2 years of age in rural Java, Indonesia. Public Health Nutrition 2011;14 (12):2197-206.

Prawirohartono EP, Nystrom L, Nurdiati DS, Hakimi $\mathrm{M}$, Lind T. The impact of prenatal vitamin A and zinc supplementation on birth size and neonatal survival - a double-blind, randomized controlled trial in a rural area of Indonesia. International Journal for Vitamin and Nutrition Research 2013;83(1):14-25.

\section{Kirkwood 2010 \{published data only\}}

Costello A, Osrin D. Vitamin A supplementation and maternal mortality. Lancet 2010;375:1675-7.

Edmond K, Hurt L, Fenty J, Amenga-Etego S, Zandoh C, Hurt C, et al. Effect of vitamin A supplementation in women of reproductive age on cause-specific early and late infant mortality in rural Ghana: ObaapaVitA double-blind, cluster-randomised, placebo-controlled trial. BMJ Open 2012;2(1):e000658.

Hurt L, Ten Asbroek A, Amenga-Etego S, Zandoh C, Danso $\mathrm{S}$, Edmond $\mathrm{K}$, et al. Effect of vitamin A supplementation on cause-specific mortality in women of reproductive age in Ghana: a secondary analysis from the ObaapaVitA trial. Bulletin of the World Health Organization 2013;91(1): 19-27.

Kirkwood B. Trial of the impact of vitamin A on maternal mortality (ObaapaVitA). http://clinicaltrials.gov/ct2/show/ NCT00211341 (accessed August 2010).

Kirkwood B. "ObaapaVitA" Vitamin A Supplementation and Maternal Mortality Trial: Randomized doubleblind placebo controlled trial to evaluate the impact of vitamin A supplementation maternal mortality in Ghana. http://www.lshtm.ac.uk/nphir/research/obaapavita/ Obaapa 'Trial' Protocol.pdf (accessed August 2010). Kirkwood BR, Hurt L, Amenga-Etego S, Tawiah C, Zandoh C, Danso S, et al. Effect of vitamin A supplementation in women of reproductive age on maternal survival in Ghana (ObaapaVitA): a cluster-randomised, placebo-controlled trial. Personal communication.

* Kirkwood BR, Hurt L, Amenga-Etego S, Tawiah 
C, Zandoh C, Danso S, et al. Effect of vitamin A supplementation in women of reproductive age on maternal survival in Ghana (obaapavita): a cluster-randomised, placebo-controlled trial. Lancet 2010;375(9726):1640-9.

Kumwenda 2002 \{published data only\}

Kumwenda N, Miotti PG, Taha TE, Broadhead R, Biggar RJ, Jackson JB, et al. Antenatal vitamin A supplementation increases birth weight and decreases anemia among infants born to human immunodeficiency virus-infected women in Malawi. Clinical Infectious Diseases 2002;35(5):618-24.

Muslimatun 2001 \{published data only\}

* Muslimatun S, Schmidt MK, Schultink W, West CE, Hautvast JGAJ, Gross R, et al. Weekly supplementation with iron and vitamin A during pregnancy increases hemoglobin concentration but decreases serum ferritin concentration in Indonesian pregnant women. Journal of Nutrition 2001;131(1):85-90.

Muslimatun S, Schmidt MK, West CE, Schultink W, Gross R, Hautvast JG. Determinants of weight and length of Indonesian neonates. European Journal of Clinical Nutrition 2002;56(10):947-51.

Muslimatun S, Schmidt MK, West CE, Schultink W, Hautvast JG, Karyadi D. Weekly vitamin A and iron supplementation during pregnancy increases vitamin a concentration of breast milk but not iron status in Indonesian lactating women. Journal of Nutrition 2001;131 (10):2664-9.

Schmidt MK, Muslimatun S, Schultink W, West CE, Hautvast JG. Randomised double-blind trial of the effect of vitamin A supplementation of Indonesian pregnant women on morbidity and growth of their infants during the first year of life. European Journal of Clinical Nutrition 2002;56 (4):338-46.

Schmidt MK, Muslimatun S, West CE, Schultink W, Hautvast JG. Mental and psychomotor development in Indonesian infants of mothers supplemented with vitamin A in addition to iron during pregnancy. British Journal of Nutrition 2004;91(2):279-85.

Schmidt MK, Muslimatun S, West CE, Schultink W, Hautvast JG. Vitamin A and iron supplementation of Indonesian pregnant women benefits vitamin a status of their infants. British Journal of Nutrition 2001;86(5): $607-15$.

Radhika 2003 \{published data only\}

Radhika MS, Bhaskaram P, Balakrishna N, Ramalakshmi BA. Red palm oil supplementation: a feasible diet-based approach to improve the vitamin A status of pregnant women and their infants. Food \& Nutrition Bulletin 2003; 24(2):208-17.

Semba 2001 \{published data only\}

* Semba RD, Kumwenda N, Taha TE, Mtimavalye L, Broadhead R, Garrett E, et al. Impact of vitamin A supplementation on anaemia and plasma erythropoietin concentrations in pregnant women: a controlled clinical trial. European Journal of Haematology 2001;66(6):389-95. Semba RD, Kumwenda N, Taha TE, Mtimavalye L, Broadhead R, Miotti PG, et al. Plasma and breast milk vitamin A as indicators of vitamin A status in pregnant women. International Journal for Vitamin and Nutrition Research 2000;70(6):271-7.

Suharno 1993 \{published data only\}

Suharno D, West CE, Muhilal, Karyadi D, Hautvast JG. Supplementation with vitamin A and iron for nutritional anaemia in pregnant women in West Java, Indonesia. Lancet 1993;342(8883):1325-8.

Sun 2010 \{published data only\} Sun YY, Ma AG, Yang F, Zhang FZ, Luo YB, Jiang DC, et al. A combination of iron and retinol supplementation benefits iron status, IL-2 level and lymphocyte proliferation in anemic pregnant women. Asia Pacific Journal of Clinical Nutrition 2010;19(4):513-9.

\section{Suprapto 2002 \{published data only\}}

Suprapto B, Widardo, Suhanantyo. Effect of low-dosage vitamin $A$ and riboflavin on iron-folate supplementation in anaemic pregnant women. Asia Pacific Journal of Clinical Nutrition 2002;11(4):263-7.

Tanumihardjo 2002 \{published data only\}

Tanumihardjo SA. Vitamin A and iron status are improved by vitamin $A$ and iron supplementation in pregnant Indonesian women. Journal of Nutrition 2002;132: 1909-12.

\section{van den Broek 2006 \{published data only\}} van den Broek NR. Double-blind randomised trial of antenatal vitamin A supplementation in pregnant anaemic women in rural Malawi. Personal communication 1999. * van den Broek NR, White SA, Flowers C, Cook JD, Letsky EA, Tanumihardjo SA, et al. Randomised trial of vitamin A supplementation in pregnant women in rural Malawi found to be anaemic on screening by HemoCue. BJOG: an international journal of obstetrics and gynaecology 2006;113(5):569-76.

West 1999 \{published data only\}

Checkley W, West KP Jr, Wise RA, Baldwin MR, Wu L, LeClerq SC, et al. Maternal vitamin A supplementation and lung function in offspring. New England Journal of Medicine 2010;362(19):1784-94.

Christian P, Khatry SK, Yamini S, Stallings R, LeClerq SC, Shrestha SR, et al. Zinc supplementation might potentiate the effect of vitamin $\mathrm{A}$ in restoring night vision in pregnant Nepalese women. American Journal of Clinical Nutrition 2001;73(6):1045-51.

Christian P, West KP Jr, Katz J, Kimbrough-Pradhan E, LeClerq SC, Khatry SK, et al. Cigarette smoking during pregnancy in rural Nepal. Risk factors and effects of betacarotene and vitamin A supplementation. European Journal of Clinical Nutrition 2004;58(2):204-11.

Christian P, West KP Jr, Khatry SK, Katz J, LeClerq S, Pradhan EK, et al. Vitamin A or beta-carotene supplementation reduces but does not eliminate maternal night blindness in Nepal. Journal of Nutrition 1998;128: 1458-63.

Christian P, West KP Jr, Khatry SK, Kimbrough-Pradhan E, LeClerq SC, Katz J, et al. Night blindness during pregnancy 
and subsequent mortality among women in Nepal: effects of vitamin A and beta-carotene supplementation. American Journal of Epidemiology 2000;152:542-7.

Christian P, West KP Jr, Khatry SK, LeClerq SC, Kimbrough-Pradhan E, Katz J, et al. Maternal night blindness increases risk of mortality in the first 6 months of life among infants in Nepal. Journal of Nutrition 2001;131 (5):1510-2.

Christian P, West KP, Khatry SK, Katz J, LeClerq SC, Kimbrough-Pradhan E, et al. Vitamin a or beta-carotene supplementation reduces symptoms of illness in pregnant and lactating Nepali women. Journal of Nutrition 2000; 130:2675-82.

Congdon NG, Dreyfuss ML, Christian P, Navitsky RC, Sanchez AM, Wu LS, et al. Responsiveness of darkadaptation threshold to vitamin $\mathrm{A}$ and beta-carotene supplementation in pregnant and lactating women in Nepal. American Journal of Clinical Nutrition 2000;72:1004-9. Katz J, West KP Jr, Khatry SK, Christian P, LeClerq SC, Pradhan EK, et al. Risk factors for early infant mortality in Sarlahi district, Nepal. Bulletin of the World Health Organization 2003;81(10):717-25.

Katz J, West KP Jr, Khatry SK, LeClerq SC, Christian P, Pradhan EK, et al. Twinning rates and survival of twins in rural Nepal. International Journal of Epidemiology 2001;30: 802-7.

Katz J, West KP Jr, Khatry SK, Pradhan EK, LeClerq SC, Christian P, et al. Maternal low-dose vitamin A or Bcarotene supplementation has no effect on fetal loss and early infant mortality: a randomized cluster trial in Nepal. American Journal of Clinical Nutrition 2000;71:1570-6.

Olsen SF. Effect of vitamin a and beta carotene supplementation on women's health. BMJ 1999;318 (7183):551-2.

Palmer AC, Schulze KJ, West KP. Preconceptional through post-partum vitamin A (VA) supplementation increases natural antibody concentrations of offspring aged 9-13 years in rural Nepal. FASEB Journal 2011;25:333.7.

Stewart CP, Christian P, Katz J, Schulze KJ, Wu LSF, LeClerq SC, et al. Maternal supplementation with vitamin $\mathrm{A}$ or B-carotene and cardiovascular risk factors among preadolescent children in rural Nepal. Journal of Developmental Origins of Health and Disease 2010;1(4):262-70.

Stewart CP, Christian P, Schulze KJ, Arguello M, Leclerq SC, Khatry SK, et al. Low maternal vitamin B-12 status is associated with offspring insulin resistance regardless of antenatal micronutrient supplementation in rural Nepal. Journal of Nutrition 2011;141(10):1912-7.

* West KP Jr, Katz J, Khatry SK, LeClerq SC, Pradhan EK, Shrestha SR, et al. Double blind, cluster randomised trial of low dose supplementation with vitamin A or beta carotene on mortality related to pregnancy in Nepal: the nnips-2 study group. BMJ 1999;318(7183):570-5.

Yamini S, West KP Jr, Wu L, Dreyfuss ML, Yang DX, Khatry SK. Circulating levels of retinol, tocopherol and carotenoid in Nepali pregnant and postpartum women following long-term beta-carotene and vitamin A supplementation.
European Journal of Clinical Nutrition 2001;55:252-9.

West 2011 \{published data only\}

Christian P, Klemm R, Shamim AA, Ali H, Rashid M, Shaikh S, et al. Effects of vitamin A and beta-carotene supplementation on birth size and length of gestation in rural Bangladesh: a cluster-randomized trial. American Journal of Clinical Nutrition 2013;97(1):188-94. Christian P, Labrique AB, Ali H, Richman MJ, Wu L, Rashid M, et al. Maternal vitamin A and betacarotene supplementation and risk of bacterial vaginosis: a randomized controlled trial in rural Bangladesh. American Journal of Clinical Nutrition 2011;94(6):1643-9.

Labrique AB, Christian P, Klemm RDW, Rashid M, Shamim AA, Massie A, et al. A cluster-randomized, placebo-controlled, maternal vitamin A or beta-carotene supplementation trial in Bangladesh: design and methods. Trials 2011;12:102.

Shaikh S, Schulze KJ, Ali H, Labrique AB, Shamim AA, Rashid M, et al. Bioelectrical impedance among rural Bangladeshi Women during pregnancy and in the postpartum period. Journal of Health, Population \& Nutrition 2011;29(3):236-44.

* West KPJ, Christian P, Labrique AB, Rashid M, Shamim AA, Klemm RD, et al. Effects of vitamin A or beta carotene supplementation on pregnancy-related mortality and infant mortality in rural Bangladesh: a cluster randomized trial. JAMA 2011;305(19):1986-95.

\section{References to studies excluded from this review}

\section{Alam 2010 \{published data only\}}

Alam DS, van Raaij JM, Hautvast JG, Yunus M, Wahed MA, Fuchs GJ. Effect of dietary fat supplementation during late pregnancy and first six months of lactation on maternal and infant vitamin A status in rural Bangladesh. Journal of Health, Population \& Nutrition 2010;28(4):333-42.

\section{Banerjee 2009 \{published data only\}}

Banerjee S, Jeyaseelan S, Guleria R. Trial of lycopene to prevent pre-eclampsia in healthy primigravidas: results show some adverse effects. Journal of Obstetrics and Gynaecology Research 2009;35(3):477-82.

\section{Chawla 1995 \{published data only\}}

Chawla PK, Puri R. Impact of nutritional supplements on hematological profile of pregnant women. Indian Pediatrics 1995;32:876-80.

\section{Chikobvu 2001 \{published data only\}}

Chikobvu P, Jouvert G, Schall R, Steinberg WJ, Viljoen JI, Kotze M, et al. The effect of vitamin A on reducing mother-to-child transmission of HIV in Bloemfontein. 21st Conference on Priorities in Perinatal Care in South Africa; 2002 March 5-8; Eastern Cape, South Africa. 2002.

* Chikobvu P, van der Ryst E, Joubert G, Steinberg WJ, Voljoen JI, Kriel J, et al. Preliminary results of a double blind randomised controlled trial testing the effect of vitamin A in mother to child transmission of HIV-1. 20th Conference on Priorities in Perinatal Care in Southern Africa; 2001 March 6-9; KwaZulu-Natal, South Africa. 2001. 
Christian 2003 \{published data only\}

Christian P, Darmstadt GL, Wu L, Khatry SK, LeClerq

SC, Katz J, et al. The effect of maternal micronutrient supplementation on early neonatal morbidity in rural Nepal: a randomised, controlled, community trial. Archives of Disease in Childhood 2008;93(8):660-4.

Christian P, Jiang T, Khatry SK, LeClerq SC, Shrestha SR, West Jr KP. Antenatal supplementation with micronutrients and biochemical indicators of status and subclinical infection in rural Nepal. American Journal of Clinical Nutrition 2006;83:788-94.

* Christian P, Khatry SK, Katz J, Pradhan EK, LeClerq SC, Shrestha SR, et al. Effects of alternative maternal micronutrient supplements on low birth weight in rural Nepal: double blind randomised community trial. BMJ 2003;326(7389):571.

Christian P, Khatry SK, LeClerq SC, Dali SM. Effects of prenatal micronutrient supplementation on complications of labor and delivery and puerperal morbidity in rural Nepal. International Journal of Gynecology \& Obstetrics 2009;106(1):3-7.

Christian P, Shrestha J, LeClerq SC, Khatry SK, Jiang T, Wagner T, et al. Supplementation with micronutrients in addition to iron and folic acid does not further improve the hematologic status of pregnant women in rural Nepal. Journal of Nutrition 2003;133(11):3492-8.

Christian P, Stewart CP, LeClerq SC, Wu L, Katz J, West KP $\mathrm{Jr}$, et al. Antenatal and postnatal iron supplementation and childhood mortality in rural Nepal: a prospective followup in a randomized, controlled community trial. American Journal of Epidemiology 2009;170(9):1127-36.

Katz J, Christian P, Dominici F, Zeger SL. Treatment effects of maternal micronutrient supplementation vary by percentiles of the birth weight distribution in rural Nepal. Journal of Nutrition 2006;136(5):1389-94.

Stewart CP, Christian P, Schulze KJ, Leclerq SC, West KP Jr, Khatry SK. Antenatal micronutrient supplementation reduces metabolic syndrome in 6- to 8-year-old children in rural Nepal. Journal of Nutrition 2009;139(8):1575-81.

Darboe 2007 \{published data only\}

Darboe MK, Thurnham DI, Morgan G, Adegbola RA, Secka O, Solon JA, et al. Effectiveness of an early supplementation scheme of high-dose vitamin A versus standard WHO protocol in Gambian mothers and infants: a randomised controlled trial. Lancet 2007;369(9579): 2088-96.

Haskell 2005 \{published data only\}

Graham JM, Haskell MJ, Pandey P, Shrestha RK, Brown $\mathrm{KH}$, Allen LH. Supplementation with iron and riboflavin enhances dark adaptation response to vitamin A-fortified rice in iron-deficient, pregnant, nightblind Nepali women. American Journal of Clinical Nutrition 2007;85(5):1375-84. * Haskell MJ, Pandey P, Graham JM, Peerson JM, Shrestha RK, Brown KH. Recovery from impaired dark adaptation in nightblind pregnant Nepali women who receive small daily doses of vitamin A as amaranth leaves, carrots, goat liver, vitamin A-fortified rice, or retinyl palmitate. American Journal of Clinical Nutrition 2005;81:461-71.

Howells 1986 \{published data only\}

Howells DW, Haste F, Rosenberg D, Brown IR, Brooke OG. Investigation of vitamin a nutrition in pregnant British Asians and their infants. Human Nutrition. Clinical Nutrition 1986;40(1):43-50.

Humphrey 2006 \{published data only\} Humphrey JH, Iliff PJ, Marinda ET, Mutasa K, Moulton $\mathrm{LH}$, Chidawanyika $\mathrm{H}$, et al. Effects of a single large dose of vitamin A, given during the postpartum period to HIVpositive women and their infants, on child HIV infection, HIV-free survival, and mortality. Journal of Infectious Diseases 2006;193(6):860-71.

\section{Laitinen 2009 \{published data only\}}

Laitinen K, Isolauri E, Kaipiainen L, Gylling H, Miettinen TA. Plant stanol ester spreads as components of a balanced diet for pregnant and breast-feeding women: evaluation of clinical safety. British Journal of Nutrition 2009;101(12): 1797-804.

Lietz 2001 \{published data only\}

* Lietz G, Henry CJK, Mulokozi G, Mugyabuso JKL, Ballart A, Ndossi GD, et al. Comparison of the effects of supplemental red palm oil and sunflower oil on maternal vitamin A status. American Journal of Clinical Nutrition 2001;74(4):501-9.

Lietz G, Mulokozi G, Henry JC, Tomkins AM. Xanthophyll and hydrocarbon carotenoid patterns differ in plasma and breast milk of women supplemented with red palm oil during pregnancy and lactation. Journal of Nutrition 2006; 136(7):1821-7.

Roberfroid 2010 \{published data only\} Roberfroid D, Huybregts L, Lanou H, Henry MC, Meda N, Kolsteren P. Effect of maternal multiple micronutrient supplements on cord blood hormones: a randomized controlled trial. American Journal of Clinical Nutrition 2010;91:1649-58.

Roy 1997 \{published data only\}

Roy SK, Islam A, Molla A, Akramuzzaman SM, Jahan F, Fuchs G. Impact of a single megadose of vitamin a at delivery on breastmilk of mothers and morbidity of their infants. European Journal of Clinical Nutrition 1997;51(5): 302-7.

\section{Sharma 2003 \{published data only\}} Sharma JB, Kumar A, Malhotra M, Arora R, Prasad S, Batra $S$. Effect of lycopene on pre-eclampsia and intra-uterine growth retardation in primigravidas. International Journal of Gynecology and Obstetrics 2003;81:257-62.

Van Vliet 2001 \{published data only\}

Van Vliet T, Boelsma E, De Vries AJ, Van den Berg H. Retinoic acid metabolites in plasma are higher after intake of liver paste compared with a vitamin a supplement in women. Journal of Nutrition 2001;131(12):3197-203.

\section{References to ongoing studies}




\section{Ahmad 2009 \{published data only\}}

Ahmad SM. Vitamin A and maternal-infant flu vaccine response. ClinicalTrials.gov (http://clinicaltrials.gov/) [accessed 1 November 2014] 2009.

\section{Additional references}

\section{AIDS Report 2008}

World Health Organization. 2008 Report on the global AIDS epidemic. Status of global HIV epidemic (http://whqlibdoc.who.int/unaids/2008/ 9789291737116 eng Chapter2A.pdf). Geneva: World Health Organization, 2008:29-51.

\section{Angeles-Agdeppa 1997}

Angeles-Agdeppa I, Schultink W, Sastroamidjojo S, Gross R, Karyadi D. Weekly micronutrient supplements to build iron stores in female Indonesian adolescents. American Journal of Clinical Nutrition 1997;66:177-83.

\section{Arsenault 2010}

Arsenault JE, Aboud S, Manji KP, Fawzi WW, Villamor E. Vitamin supplementation increases risk of subclinical mastitis in HIV-infected women. Journal of Nutrition 2010; 140(10): 1788-92.

\section{Bloem 1990}

Bloem MW, Wedel M, Van Agtmaal EJ, Speek AJ, Soawakontha S, Schreurs WHP. Vitamin A intervention: short term effects of a single oral massive dose on iron metabolism. American Journal of Clinical Nutrition 1990; 51:76-9.

\section{Borel 2005}

Borel P, Drai J, Faure H. Recent knowledge about intestinal absorption and cleavage of carotenoids. Annales de Biologie Clinique 2005;63(2):165-77.

\section{Christian 2011}

Christian P, Labrique AB, Ali H, Richman MJ, Wu L, Rashid M, et al. Maternal vitamin A and betacarotene supplementation and risk of bacterial vaginosis: a randomized controlled trial in rural Bangladesh. American Journal of Clinical Nutrition 2011;94(6):1643-9.

\section{Christian 2013}

Christian P, Klemm R, Shamim AA, Ali H, Rashid M, Shaikh $S$, et al. Effects of vitamin A and beta-carotene supplementation on birth size and length of gestation in rural Bangladesh: a cluster-randomized trial. American Journal of Clinical Nutrition 2013;97(1):188-94.

\section{Combs 2008}

Combs GF. The Vitamins: Fundamental Aspects in Nutrition and Health. 3rd Edition. Burlington: Elsevier Academic Press, 2008.

\section{Cox 2006}

Cox SE, Arthur P, Kirkwood BR. Vitamin A supplementation increases ratios of pro-inflammatory to anti-inflammatory cytokine responses in pregnancy and lactation. Clinical \& Experimental Immunology 2006;144 (3):392-400.
Darlow 2007

Darlow BA, Graham PJ. Vitamin A supplementation to prevent mortality and short- and long-term morbidity in very low birthweight infants. Cochrane Database of Systematic Reviews 2011, Issue 10. [DOI: 10.1002/ 14651858.CD000501.pub3]

Dijkhuizen 2001

Dijkhuizen MA. Vitamin A, Iron and Zinc Deficiency in Indonesia. Micronutrient Interactions and Effects of Supplementation [thesis]. Wageningen University, 2001.

\section{DRI 2001}

Institute of Medicine. Dietary Reference Intakes for Vitamin A, Vitamin K, Arsenic, Boron, Chromium, Copper, Iodine, Iron, Manganese, Molybdenum, Nickel, Silicon, Vanadium, and Zinc. Washington, DC: National Academy Press, 2001.

\section{Edmond 2012}

Edmond K, Hurt L, Fenty J, Amenga-Etego S, Zandoh C, Hurt C, et al. Effect of vitamin A supplementation in women of reproductive age on cause-specific early and late infant mortality in rural Ghana: ObaapaVitA double-blind, cluster-randomised, placebo-controlled trial. BMJ Open 2012;2(1):e000658.

\section{FAO and WHO 2002}

FAO, WHO 2002. Vitamin A. Human Vitamin and Mineral Requirements: Report of a Joint FAO/WHO Expert Consultation Bangkok, Thailand. Rome: WHO, 2002: 87-107.

Fawzi 1993

Fawzi WW, Chalmers TC, Herrera MG, Mosteller F. Vitamin A supplementation and child mortality. A metaanalysis. JAMA 1993;269(7):898-903.

\section{FNB 2001}

Food, Nutrition Board. Dietary Reference Intakes. Washington DC: National Academy Press, 2001.

\section{Glasziou 1993}

Glasziou PP, Mackerras DE. Vitamin A supplementation in infectious diseases: a meta-analysis. BMJ 1993;306: 366-70.

\section{Haider 2008}

Haider BA, Bhutta ZA. Multiple-micronutrient supplementation for women during pregnancy. Cochrane Database of Systematic Reviews 2012, Issue 11. [DOI: 10.1002/14651858.CD004905.pub3]

\section{HAP 2008}

Health in Asia and the Pacific. Mortality. http://www.wpro.who.int/NR/rdonlyres/ 3156FAEA-AE96-4C3D-ADF9-302C5831A618/0/ 10 . Chapter5Mortality.pdf (accessed 2008).

\section{Higgins 2011}

Higgins JPT, Green S, editors. Cochrane Handbook for Systematic Reviews of Interventions Version 5.1.0 [updated March 2011]. The Cochrane Collaboration, 2011. Available from www.cochrane-handbook.org. 


\section{Hodges 1978}

Hodges RE, Sauberlich HE, Canham JE, Wallace DL, Rucker RB, Meija LA, et al. Hematopoietic studies in vitamin A deficiency. American Journal of Clinical Nutrition 1978;31:876-85.

\section{Hurt 2013}

Hurt L, Ten Asbroek A, Amenga-Etego S, Zandoh C, Danso $S$, Edmond K, et al. Effect of vitamin A supplementation on cause-specific mortality in women of reproductive age in Ghana: a secondary analysis from the ObaapaVitA trial. Bulletin of the World Health Organization 2013;91(1): $19-27$.

\section{ICD-10 2007}

World Health Organization. International classification of diseases and related heath problems. 10th revision. Version for 2007. http://apps.who.int/classifications/apps/icd/ icd10online/ (accessed June 2010).

\section{IMCI- TAG 2008}

World Health Organization. Technical Advisory Group on IMCI (IMCI-TAG). Integrated Management in the Context of the Maternal-Newborn-Child Health Continuum. Report of the Fifth Meeting; Texas Children's Hospital; 2006 May 16-17; Houston, Texas, USA. Washington: Pan American Health Organization, 2008.

\section{Karyadi 1996}

Karyadi D, Bloem MW. The role of vitamin A deficiency in iron deficiency anaemia and implications for interventions. Biomedical and Environmental Sciences 1996;9:316-24.

\section{Lidén 2006}

Lidén M, Eriksson U. Understanding retinol metabolism: structure and function of retinol dehydrogenases. Journal of Biological Chemistry 2006;281(19):13001-4.

Long 2007

Long KZ, Rosado JL, DuPont HL. Supplementation with vitamin A reduces watery diarrhoea and respiratory infections in Mexican children. British Journal of Nutrition 2007;97(2):337-43.

\section{Mahalanabis 1979}

Mahalanabis D, Simpson TN, Chakraborty ML, Ganguli C, Bhattacharjee AK, Mukherjee KL. Malabsorption of water miscible vitamin $\mathrm{A}$ in children with giardiasis and ascariasis. American Journal of Clinical Nutrition 1979;32: 313-8.

\section{McGuire 2007}

McGuire M, Beerman KA. Nutritional Sciences: From Fundamentals to Food. 1st Edition. Belmont, CA: Thomson/Wadsworth, 2007.

Mejia 1977

Mejia LA, Hodges RE, Arroyave G. Vitamin A deficiency and anaemia in Central American children. American Journal of Clinical Nutrition 1977;30:1175-84.

\section{Mejia 1982}

Mejia LA, Arroyave G. The effect of vitamin A fortification of sugar on iron metabolism in preschool children in
Guatemala. American Journal of Clinical Nutrition 1982;36 (1):87-93. [PUBMED: 7091038]

\section{Mejia 1988}

Mejia LA, Chew F. Hematological effect of supplementing anemic children with vitamin $\mathrm{A}$ alone and in combination with iron. American Journal of Clinical Nutrition 1988;48: 595-600.

\section{Miller 1998}

Miller RK, Hendrckx AG, Mills JL, Hummler H, Wiegand UW. Periconceptional vitamin A use: how much is teratogenic?. Reproductive Toxicology 1998;12(1):75-88.

Mills 1997

Mills JL, Simpson JL, Cunningham GC, Conley MA, Rhoads GG. Vitamin A and birth defects. American Journal of Obstetrics and Gynecology 1997;177:31-6.

\section{Moffa 1970}

Moffa DJ, Lotspeich FJ, Krause RF. Preparation and properties of retinal-oxidizing enzyme from rat intestinal mucosa. Journal of Biological Chemistry 1970;245:439-47.

\section{Muhilal 1988}

Muhilal, Permeisih D, Idjradinata YR. Vitamin A fortified monosodium glutamate and health, growth and survival of children: a controlled field trial. American Journal of Clinical Nutrition 1988;48:1271-6.

\section{NCCWCH 2008}

National Collaborating Centre for Women's and Children's Health. Antenatal Care: Routine Care for the Healthy Pregnant Woman. London: RCOG Press, 2008.

\section{Oliveira 2010}

Oliveira-Menegozzo JM, Bergamaschi DP, Middleton P, East CE. Vitamin A supplementation for postpartum women. Cochrane Database of Systematic Reviews 2010, Issue 10. [DOI: 10.1002/14651858.CD005944.pub2]

Olofin 2014

Olofin IO, Spiegelman D, Aboud S, Duggan C, Danaei G, Fawzi WW. Supplementation with multivitamins and vitamin A and incidence of malaria among HIV-infected Tanzanian women. Journal of Acquired Immune Deficiency Syndromes 2014;67(Suppl 4):S173-8.

PNM 2005

World Health Organization. Perinatal and Neonatal Mortality. Geneva: World Health Organization, 2005.

Prawirohartono 2011

Prawirohartono EP, Nystrom L, Ivarsson A, Stenlund $\mathrm{H}$, Lind $\mathrm{T}$. The impact of prenatal vitamin $\mathrm{A}$ and zinc supplementation on growth of children up to 2 years of age in rural Java, Indonesia. Public Health Nutrition 2011;14 (12):2197-206.

\section{Prawirohartono 2013}

Prawirohartono EP, Nystrom L, Nurdiati DS, Hakimi $\mathrm{M}$, Lind T. The impact of prenatal vitamin A and zinc supplementation on birth size and neonatal survival - a double-blind, randomized controlled trial in a rural area of Indonesia. International Journal for Vitamin and Nutrition Research 2013;83(1):14-25. 
RevMan 2014

The Nordic Cochrane Centre, The Cochrane Collaboration. Review Manager (RevMan). 5.3. Copenhagen: The Nordic Cochrane Centre, The Cochrane Collaboration, 2014.

Ross 1994

Ross AC, Gardner EM. The function of vitamin A in cellular growth and differentiation, and its roles during pregnancy and lactation. Advances in Experimental Medicine and Biology 1994;352:187-200.

Rothman 1995

Rothman KJ, Moore LL, Singer MR, Nguyen UDT, Mannino S, Milunsky A. Teratogenecity of high Vitamin A intake. New England Journal of Medicine 1995;333: 1367-73.

Rousseau 1992

Rousseau EJ, Davison AJ, Dunn B. Protection by beta-carotene and related compounds against oxygenmediated cytotoxicity and genotoxicity: implications for carcinogenesis and anticarcinogenesis. Free Radical Biology and Medicine 1992;13:407-33.

\section{Semba 2000}

Semba RD, Kumwenda N, Taha TE, Mtimavalye L, Broadhead R, Miotti PG, et al. Plasma and breast milk vitamin $A$ as indicators of vitamin A status in pregnant women. International Journal for Vitamin and Nutrition Research 2000;70(6):271-7.

Sivakumar 1972

Sivakumar B, Reddy V. Absorption of labelled vitamin A in children during infection. British Journal of Nutrition 1972; 27:297-304.

Sommer 1982

Sommer A. Nutritional Blindness. Xerophthalmia and Keratomalacia. 1st Edition. New York: Oxford University Press, 1982

Sommer 1995

Sommer A. Vitamin A Deficiency and its Consequences: a Field Guide to Detection and Control. 3rd Edition. Geneva: World Health Organization, 1995.

\section{Stephens 1996}

Stephens D, Jackson PL, Gutierrez Y. Subclinical vitamin A deficiency: a potentially unrecognized problem in the United States. Pediatric Nursing 1996;22(5):377-89.

Stipanuk 2006

Stipanuk MH. Biochemical, Physiological and Molecular Aspects of Human Nutrition. 2nd Edition. Philadelphia: Saunders, 2006.

\section{Suharno 1992}

Suharno D, West CE, Muhilal, Logman MHGM, De Waart FG, Karyadi D, et al. Cross-sectional study on the iron and Vitamin A status of pregnant women in West Java, Indonesia. American Journal of Clinical Nutrition 1992;56: 988-93.

Tang 2005

Tang G, Qin J, Dolnikowski GG, Russell RM, Grusak MA. Spinach or carrots can supply significant amounts of vitamin $\mathrm{A}$ as assessed by feeding with intrinsically deuterated vegetables. American Journal of Clinical Nutrition 2005;82 (4):821-8.

\section{Thurnham 1989}

Thurnham DI. Vitamin A deficiency and its role in infection. Transactions of the Royal Society of Tropical Hygiene and Medicine 1989;83:721-3.

Tomkins 1989

Tomkins A, Hussey G. Vitamin A, immunity and infection. Nutrition Research Reviews 1989;2:17-28.

\section{Underwood 1990}

Underwood BA. Methods for assessment of vitamin A status. Journal of Nutrition 1990;120:1459-63.

Underwood 1994

Underwood BA. Maternal vitamin A status and its importance in infancy and early childhood. American Journal of Clinical Nutrition 1994;59:517S-522S.

Van den Broek 1998

Van den Broek N. Anaemia in pregnancy in developing countries. British Journal of Obstetrics and Gynaecology 1998;105:385-90.

\section{Van den Broek 2000}

Van den Broek NR, Letsky EA. Etiology of anemia in south Malawi. American Journal of Clinical Nutrition 2000;72(1): 247S-256S.

Von Lintig 2000

Von Lintig J, Vogt K. Filling the gap in vitamin A research: molecular identification of an enzyme cleaving betacarotene to retinal. Journal of Biological Chemistry 2000;275 (16):11915-20.

\section{WHO 1995}

World Health Organization. Global Prevalence of Vitamin A Deficiency. Micronutrient Deficiency Information System (WHO/NUT/95). Geneva: WHO, 1995.

\section{WHO 1996}

World Health Organization. Indicators for assessing vitamin A deficiency and their application in monitoring and evaluating intervention programmes. 1st Edition. Geneva: World Health Organization, 1996:66.

\section{WHO 1998}

World Health Organization. Safe vitamin A dosage during pregnancy and lactation. Recommendations and report of a consultation. Geneva: WHO (WHO/NUT/98), 1998. Geneva: WHO, 1998.

\section{WHR 2005}

World Health Organization. The World Health Report 2005 - make every mother and child count. http:// www.who.int/whr/2005/en/ (accessed June 2010) 2005.

Wiysonge 2011

Wiysonge CS, Shey M, Kongnyuy EJ, Sterne JAC, Brocklehurst P. Vitamin A supplementation for reducing the risk of mother-to-child transmission of HIV infection. Cochrane Database of Systematic Reviews 2011, Issue 1. [DOI: 10.1002/14651858.CD003648.pub3] 
Wolde-Gabriel 1993

Wolde-Gabriel Z, West CE, Speek AJ. Interrelationship between Vitamin A, iodine and iron status in school children in the Shoa Region - Central Ethiopia. British Journal of Nutrition 1993; Vol. 70:593-607.

\section{References to other published versions of this review}

Van den Broek 2002

Van den Broek N, Kulier R, Gülmezoglu AM, Villar J.
Vitamin A supplementation during pregnancy. Cochrane Database of Systematic Reviews 2002, Issue 4. [DOI:

10.1002/14651858.CD001996]

van den Broek 2010

van den Broek N, Dou L, Othman M, Neilson JP, Gates $S$, Gülmezoglu AM. Vitamin A supplementation during pregnancy for maternal and newborn outcomes. Cochrane Database of Systematic Reviews 2010, Issue 11. [DOI:

10.1002/14651858.CD008666.pub2]

* Indicates the major publication for the study 


\section{CHARACTERISTICS OF STUDIES}

\section{Characteristics of included studies [ordered by study ID]}

\section{Ajans 1965}

\begin{tabular}{|c|c|}
\hline Methods & RCT. \\
\hline Participants & $\begin{array}{l}\text { Inclusion criteria: } 44 \text { parturient women in good health from the lower and middle } \\
\text { socioeconomic groups (in a population in which vitamin A deficiency occurs) }\end{array}$ \\
\hline Interventions & $\begin{array}{l}\text { Intervention group 1: } 15 \text { women. } \\
\text { Single intramuscular injection of } 600,000 \mathrm{lU} \text { of vitamin A palmitate in oil at parturi- } \\
\text { tion. } 4 \text { samples of } 2 \text { to } 3 \mathrm{~mL} \text { of colostrum were collected. } 1 \text { antepartum sample and } 3 \\
\text { postpartum samples, } 1 \text { on each consecutive day of hospitalisation } \\
\text { Intervention group } 2: 11 \text { women. } \\
\text { Given } 600,000 \mathrm{lU} \text { of water-dispersible vitamin A palmitate orally shortly before deliv- } \\
\text { ery. } 4 \text { samples of } 2 \text { to } 3 \mathrm{~mL} \text { of colostrum were collected. } 1 \text { antepartum sample and } 3 \\
\text { postpartum samples, } 1 \text { on each consecutive day of hospitalisation. Followed by public } \\
\text { health nurses at their homes where bi-weekly samples of milk were collected during the } \\
\text { first week after discharge and then weekly samples for a total period ranging between } 38 \\
\text { and } 59 \text { days postpartum } \\
\text { Control group: } 18 \text { women not given any form of vitamin A therapy prepartum. } 4 \text { samples } \\
\text { of } 2 \text { to } 3 \mathrm{~mL} \text { of colostrum were collected. } 1 \text { antepartum sample and } 3 \text { postpartum } \\
\text { samples, } 1 \text { on each consecutive day of hospitalisation }\end{array}$ \\
\hline
\end{tabular}

outcomes: levels of vitamin A and carotenoids in the colostrum prenatal and postnatal

$\begin{array}{ll}\text { Notes } & \text { Vitamin A levels measured before starting supplementation in group } 1 \text { and } 2 \\ \text { Study was done in a population in which vitamin A deficiency occurs } \\ \text { Study setting: American university hospital. }\end{array}$

\section{Risk of bias}

\begin{tabular}{l|l|l}
\hline Bias & Authors judgement & Support for judgement \\
\hline $\begin{array}{l}\text { Random sequence generation (selection } \\
\text { bias) }\end{array}$ & Unclear risk & No description except allotted at random. \\
\hline $\begin{array}{l}\text { Allocation concealment (selection bias) } \\
\begin{array}{l}\text { Blinding of participants and personnel } \\
\text { (performance bias) } \\
\text { All outcomes }\end{array}\end{array}$ & High risk & No description except allotted at random. \\
\hline
\end{tabular}

Blinding of outcome assessment (detection Unclear risk $\quad$ No information was provided.
bias)

All outcomes 


\section{Ajans 1965 (Continued)}

\begin{tabular}{l|l|l}
\hline $\begin{array}{l}\text { Incomplete outcome data (attrition bias) } \\
\text { All outcomes }\end{array}$ & Low risk & No exclusion or loss of follow-up reported. \\
\hline Selective reporting (reporting bias) & Unclear risk & The protocol of the study is not available at the moment. \\
\hline Other bias & High risk & $\begin{array}{l}\text { The } 3 \text { groups were not studied during the same period. The } \\
\text { authors reported "subjects in groups } 1 \text { and } 2 \text { were studied in the } \\
\text { summer and those of group 3 in the following winter" }\end{array}$ \\
\hline
\end{tabular}

\section{Coutsoudis 1999}

\begin{tabular}{|c|c|}
\hline Methods & Double-blind RCT. \\
\hline Participants & $\begin{array}{l}\text { Inclusion criteria: } \\
\text { - pregnant women } 28-32 \text { weeks' gestation; } \\
\text { - HIV-positive. } \\
\text { (HIV-seropositive women identified through antenatal screening programmes. All the } \\
\text { women enrolled were black Africans.) }\end{array}$ \\
\hline Interventions & $\begin{array}{l}\text { Intervention group: } 368 \text { women received daily dose of } 5000 \mathrm{IU} \text { retinyl palmitate and } \\
30 \mathrm{mg} \text { beta-carotene during the third trimester of pregnancy (together corresponding to } \\
43,400 \text { IU vitamin A daily for } 12 \text { weeks) and } 200,000 \mathrm{IU} \text { retinyl palmitate at delivery } \\
\text { Control group: } 360 \text { women received placebo on the same schedule }\end{array}$ \\
\hline Outcomes & $\begin{array}{l}\text { Primary outcome: effects of vitamin A on HIV viral load and HIV transmission } \\
\text { Other outcomes: neonatal mortality (the number of deaths during the first } 28 \text { completed } \\
\text { days of life per } 1000 \text { live births in a given year or period) and anaemia, maternal anaemia, } \\
\text { clinical infection (fever }>1 \text { week at } 1 \text { week postnatally), preterm birth (delivery less } \\
\text { than } 37 \text { completed weeks' gestational age estimated using LMP), low birthweight and } \\
\text { morbidity }\end{array}$ \\
\hline Notes & $\begin{array}{l}\text { Vitamin A levels were measured before starting supplementation } \\
\text { Country: South Africa. } \\
\text { Study setting: King Edward VIII Hospital and McCords Hospital, in Durban, South } \\
\text { Africa }\end{array}$ \\
\hline
\end{tabular}

\section{Risk of bias}

\begin{tabular}{l|l|l}
\hline Bias & Authors' judgement & Support for judgement \\
\hline $\begin{array}{l}\text { Random sequence generation (selection } \\
\text { bias) }\end{array}$ & Unclear risk & No information provided. \\
\hline $\begin{array}{l}\text { Allocation concealment (selection bias) } \\
\begin{array}{l}\text { Blinding of participants and personnel } \\
\text { (performance bias) } \\
\text { All outcomes }\end{array}\end{array}$ & Low risk & No information provided. \\
\hline
\end{tabular}




\section{Coutsoudis 1999 (Continued)}

\begin{tabular}{ll|l}
\hline $\begin{array}{l}\text { Blinding of outcome assessment (detection } \\
\text { bias) } \\
\text { All outcomes }\end{array}$ & Unclear risk & No information given. \\
\hline $\begin{array}{l}\text { Incomplete outcome data (attrition bias) } \\
\text { All outcomes }\end{array}$ & Low risk & $\begin{array}{l}57(7.8 \%) \text { women did not deliver in the hospitals and cannot } \\
\text { be traced }\end{array}$ \\
\hline $\begin{array}{l}\text { Selective reporting (reporting bias) } \\
\text { Other bias }\end{array}$ & Unclear risk & The protocol of the study is not available at the moment. \\
\hline
\end{tabular}

\section{Cox 2005}

\begin{tabular}{|c|c|}
\hline Methods & A randomised double-blind controlled trial. \\
\hline Participants & $\begin{array}{l}\text { Inclusion criteria: } \\
\text { - primigravid pregnant women; } \\
\text { - resident within the study area; } \\
\text { - in good health; } \\
\text { - less than } 24 \text { weeks pregnant. } \\
\text { Exclusion criteria: HIV infection or tuberculosis. }\end{array}$ \\
\hline Interventions & $\begin{array}{l}\text { Intervention group: } 48 \text { women received weekly capsules of } 10,000 \mathrm{IU} \text { of vitamin A as } \\
\text { retinyl palmitate in groundnut oil, plus tocopherol as a preservative from enrolment } \\
\text { until } 6 \text { weeks postpartum. Suplimintation was for a minimum of } 18 \text { weeks } \\
\text { Control group: } 50 \text { women received groundnut oil and tocopherol only in the placebo } \\
\text { capsules from enrolment until } 6 \text { weeks postpartum }\end{array}$ \\
\hline Outcomes & $\begin{array}{l}\text { Primary outcome: maternal infections (presence of placental malaria and peripheral } \\
\text { parasitaemia) } \\
\text { Other outcomes: } \mathrm{Hb} \text { and birthweight. }\end{array}$ \\
\hline Notes & $\begin{array}{l}\text { Vitamin A levels were measured before starting supplementation } \\
\text { Country: Ghana. } \\
\text { Study setting: Nkoranza District Hospital and } 3 \text { rural health clinics in Brong Ahafo } \\
\text { region, Central Ghana }\end{array}$ \\
\hline
\end{tabular}

\section{Risk of bias}

\begin{tabular}{l|ll}
\hline Bias & Authors' judgement & Support for judgement \\
\hline $\begin{array}{l}\text { Random sequence generation (selection } \\
\text { bias) }\end{array}$ & Unclear risk & "balanced block randomisation." \\
\hline Allocation concealment (selection bias) & Unclear risk & No information provided.
\end{tabular}




\section{Cox 2005 (Continued)}

Blinding of participants and personnel Low risk

Participants and personnel "double-blind".

(performance bias)

All outcomes

Blinding of outcome assessment (detection Unclear risk

bias)

All outcomes

Incomplete outcome data (attrition bias) Low risk

All outcomes

Selective reporting (reporting bias)

Unclear risk

Other bias

Unclear risk
No information given.

$12(12 \%)$ women were excluded from the analysis: 1 false pregnancy, 1 early miscarriage, 10 missed late pregnancy visit

The protocol of the study is not available at the moment.

The most marked difference was in educational level and gestational age at enrolment. Levels of anti-VSACSA IgG to the FCR3CSA parasite line differed between the treatment groups at baseline. There were considerably fewer data available for the placebo than the vitamin A group at the late pregnancy follow-up

Dijkhuizen 2004

\begin{tabular}{ll}
\hline Methods & Double-blind RCT, factorial design. \\
\hline Participants & $\begin{array}{l}\text { Inclusion criteria: all women were recruited before } 20 \text { weeks' gestational age } \\
\text { Exclusion criteria: twin pregnancy and congenital abnormalities that interfered with } \\
\text { growth, development, or metabolism }\end{array}$ \\
\hline Interventions & $\begin{array}{l}\text { Intervention group } 1: 37 \text { women received iron and folic acid supplements together with } \\
\text { B -carotene (4.5 mg as water-soluble granulate/d (representing } 5750 \text { IU of vitamin A)) } \\
\text {. Each woman was supplemented daily during pregnancy until delivery for a minimum } \\
\text { of } 16 \text { weeks } \\
\text { Intervention group 2: } 37 \text { women received iron and folic acid supplements together with } \\
\text { zinc } 30 \text { mg zinc as sulphate/d). Each woman was supplemented daily during pregnancy } \\
\text { until delivery } \\
\text { Intervention group 3: } 37 \text { women received iron and folic acid supplements together with } \\
\text { zinc and carotene. Each woman was supplemented daily during pregnancy until delivery } \\
\text { Control group: } 37 \text { women received iron and folic acid. }\end{array}$ \\
\hline Outcomes & $\begin{array}{l}\text { Primary outcome: maternal and fetal Hb and zinc levels. } \\
\text { Other outcomes: maternal and fetal ferritin, retinol and carotene levels } \\
\text { Other outcomes from this same trial were recorded by Dijkhuizen 2001- see notes below. }\end{array}$ \\
\hline
\end{tabular}


Dijkhuizen 2004 (Continued)

\begin{tabular}{ll}
\hline Notes & Vitamin A levels were not measured before starting supplementation \\
& Country: Indonesia. \\
& Study setting: 13 adjacent villages in a rural area in Bogor District, West Java, Indonesia \\
& Dijkhuizen 2001 assessed maternal and neonatal complications in this same trial de- \\
scribed above. Outcomes described included maternal puerperal fever, preterm delivery, \\
stillbirth, neonatal mortality and birthweight
\end{tabular}

Risk of bias

\begin{tabular}{|c|c|c|}
\hline Bias & Authors' judgement & Support for judgement \\
\hline $\begin{array}{l}\text { Random sequence generation (selection } \\
\text { bias) }\end{array}$ & Unclear risk & $\begin{array}{l}\text { No information provided except factorial ran- } \\
\text { domisation. }\end{array}$ \\
\hline Allocation concealment (selection bias) & Low risk & $\begin{array}{l}\text { "Capsules were indistinguishable and given a let- } \\
\text { ter code." }\end{array}$ \\
\hline $\begin{array}{l}\text { Blinding of participants and personnel } \\
\text { (performance bias) } \\
\text { All outcomes }\end{array}$ & Low risk & Participants and personnel double-blind". \\
\hline $\begin{array}{l}\text { Blinding of outcome assessment (detection } \\
\text { bias) } \\
\text { All outcomes }\end{array}$ & Low risk & No information given. \\
\hline $\begin{array}{l}\text { Incomplete outcome data (attrition bias) } \\
\text { All outcomes }\end{array}$ & Low risk & $\begin{array}{l}35(20 \%) \text { women were not followed up or in- } \\
\text { cluded in the analyses }\end{array}$ \\
\hline Selective reporting (reporting bias) & Unclear risk & $\begin{array}{l}\text { The protocol of the study is not available at the } \\
\text { moment. }\end{array}$ \\
\hline Other bias & Low risk & No other bias awarded. \\
\hline
\end{tabular}

Fawzi 1998

Methods

Participants

Interventions 2-by-2 factorial design.

Inclusion criteria:

- pregnant women 12-27 weeks' gestation;

- HIV-positive women;

- resident in Dar es Salaam at the time of baseline interview;

- intend to stay in the city until delivery and 1 year breastfeeding thereafter.

Intervention group 1: 270 women received a daily (for at least 10 weeks) oral dose of multivitamins including vitamin A (30 mg b-carotene (representing 38,000 IU vitamin A) and $5000 \mathrm{IU}$ of preformed vitamin A, $20 \mathrm{mg}$ of B1, $20 \mathrm{mg}$ of B2, $25 \mathrm{mg}$ of B6, 100 $\mathrm{mg}$ of niacin, $50 \mathrm{mg}$ of B12, $500 \mathrm{mg}$ of C, $30 \mathrm{mg}$ of vitamin $\mathrm{E}$, and $0.8 \mathrm{mg}$ of folic acid) ; an additional oral dose of vitamin A (200,000 IU) at delivery 
Intervention group 2: 269 women received a daily oral dose of vitamin A alone (30 mg b-carotene and 5000 IU of preformed vitamin A), plus an additional oral dose of vitamin A $(200,000$ IU) at delivery

Intervention group 3: 269 women received a daily oral dose of multivitamins excluding vitamin A, plus an additional oral placebo at delivery

Intervention group 4: 267 women received a daily oral dose of placebo. An additional oral placebo at delivery

Primary outcome: CD levels in both mother and fetus and HIV transmission

Other outcomes: birthweight, preterm birth (delivery less than 37 completed weeks estimated using $\mathrm{LMP})$ and $\mathrm{Hb}$ in both mother and fetus $(\mathrm{Hb}<10.0 \mathrm{~g} / \mathrm{dL})$

Notes
Vitamin A levels were measured before starting supplementation
Country: Tanzania.
Duration: $1995-1997$.
Study setting: 4 ANCs with several smaller peripheral clinics
Other secondary outcomes of interest in this review (maternal infection) from this trial
are described by Arsenault 2010 and Olofin 2014.

Risk of bias

\begin{tabular}{|c|c|c|}
\hline Bias & Authors' judgement & Support for judgement \\
\hline $\begin{array}{l}\text { Random sequence generation (selection } \\
\text { bias) }\end{array}$ & Unclear risk & "Randomisation was done in blocks of 20." \\
\hline Allocation concealment (selection bias) & Low risk & $\begin{array}{l}\text { "At enrolment, we assigned each eligible women the next num- } \\
\text { bered bottle of regimen." }\end{array}$ \\
\hline $\begin{array}{l}\text { Blinding of participants and personnel } \\
\text { (performance bias) } \\
\text { All outcomes }\end{array}$ & Low risk & Participants and personnel "double blind". \\
\hline $\begin{array}{l}\text { Blinding of outcome assessment (detection } \\
\text { bias) } \\
\text { All outcomes }\end{array}$ & Low risk & No information. \\
\hline $\begin{array}{l}\text { Incomplete outcome data (attrition bias) } \\
\text { All outcomes }\end{array}$ & Low risk & $\begin{array}{l}117 \text { ( } 10.8 \%) \text { women were excluded from the analysis: } \\
\text { - } 3 \text { not pregnant; } \\
\text { - } 7 \text { died before delivery and excluded; } \\
\text { - } 54 \text { lost to follow-up; } \\
\text { - } 53 \text { no date of delivery or gestational age. }\end{array}$ \\
\hline Selective reporting (reporting bias) & Unclear risk & The protocol of the study is not available at the moment. \\
\hline Other bias & Low risk & No other bias awarded. \\
\hline
\end{tabular}


Green 1931

Methods

Participants

Interventions

Outcomes

Maternal infection (puerperal fever $>38^{\circ} \mathrm{C}$ ) and maternal and baby mortality and morbidity.

Notes
Quasi-RCT, multi-centred.

Inclusion criteria: pregnant women.

Exclusion criteria: cases not delivered in hospital.

Intervention group: 275 women received $1 \mathrm{oz}$ of the vitamin preparation radiostoleum, an amount equivalent in vitamins $\mathrm{A}$ and $\mathrm{D}$ roughly to $30 \mathrm{oz}$ of a good cod-liver oil (equivalent to 444,000 IU vitamin A), should have been taken daily commencing 1 month previous to the calculated day of labour

The first 76 cases prior to June 1929 were given the preparation for only 14 days before delivery (daily). It was, however, continued for the first 7 days of the puerperium. It was then decided that a more logical procedure would probably be to begin the administration earlier and thus build up a larger reserve at the time of labour

Control group: 275 women received an untreated version.

\begin{tabular}{|c|c|c|}
\hline (2) & \multicolumn{2}{|c|}{$\begin{array}{l}\text { Country: UK. } \\
\text { Study setting: the Jessop Hospital and the Nether Edge municipal hospital }\end{array}$} \\
\hline \multicolumn{3}{|l|}{ Risk of bias } \\
\hline Bias & Authors' judgement & Support for judgement \\
\hline $\begin{array}{l}\text { Random sequence generation (selection } \\
\text { bias) }\end{array}$ & High risk & $\begin{array}{l}\text { "the first patient was given the preparation and the next } \\
\text { due for delivery about the same time was indexed as a } \\
\text { control." }\end{array}$ \\
\hline Allocation concealment (selection bias) & High risk & $\begin{array}{l}\text { "the first patient was given the preparation and the next } \\
\text { due for delivery about the same time was indexed as a } \\
\text { control." }\end{array}$ \\
\hline $\begin{array}{l}\text { Blinding of participants and personnel } \\
\text { (performance bias) } \\
\text { All outcomes }\end{array}$ & High risk & The control group received no intervention. \\
\hline $\begin{array}{l}\text { Blinding of outcome assessment (detection } \\
\text { bias) } \\
\text { All outcomes }\end{array}$ & Unclear risk & No information provided. \\
\hline $\begin{array}{l}\text { Incomplete outcome data (attrition bias) } \\
\text { All outcomes }\end{array}$ & Low risk & $\begin{array}{l}50(8.3 \%) \text { women delivered somewhere else and were ex- } \\
\text { cluded. }\end{array}$ \\
\hline Selective reporting (reporting bias) & Unclear risk & The protocol of the study is not available at the moment. \\
\hline Other bias & Low risk & No other bias awarded. \\
\hline
\end{tabular}




\begin{tabular}{ll} 
Methods & Randomised, placebo-controlled double masked community-based trial \\
\hline Participants & $\begin{array}{l}\text { Inclusion: women with positive pregnancy test in the first } 120 \text { days of pregnancy } \\
\text { Exclusion: }\end{array}$ \\
\hline $\begin{array}{l}- \text { women who were not married or did not have a life partner; } \\
- \text { women whose gestational age }>\text { first trimester; }\end{array}$ \\
\hline peri-menopausal women.
\end{tabular}

Risk of bias

\begin{tabular}{|c|c|c|}
\hline Bias & Authors' judgement & Support for judgement \\
\hline $\begin{array}{l}\text { Random sequence generation (selection } \\
\text { bias) }\end{array}$ & Low risk & $\begin{array}{l}\text { " } 1: 1: 1: 1 \text { ratio in blocks of } 12 \text { based on a } \\
\text { list of treatment numbers derived from a } \\
\text { pseudo-random number generator in SAS. } \\
\text { " }\end{array}$ \\
\hline Allocation concealment (selection bias) & Low risk & $\begin{array}{l}\text { "treatment allocation sequence was pre- } \\
\text { pared and held at .. a site remote from the } \\
\text { trial." }\end{array}$ \\
\hline $\begin{array}{l}\text { Blinding of participants and personnel } \\
\text { (performance bias) } \\
\text { All outcomes }\end{array}$ & Low risk & $\begin{array}{l}\text { "supplements were packaged in ...identical } \\
\text { opaque pink capsules." } \\
\text { "all investigators, field and laboratory staff } \\
\text { and participants were blinded to the treat- } \\
\text { ment code." }\end{array}$ \\
\hline $\begin{array}{l}\text { Blinding of outcome assessment (detection } \\
\text { bias) } \\
\text { All outcomes }\end{array}$ & Low risk & $\begin{array}{l}\text { "a survey of sample of field workers and } \\
\text { their supervisors revealed they were unable } \\
\text { to identify which treatments the study par- } \\
\text { ticipants were receiving." }\end{array}$ \\
\hline
\end{tabular}

Incomplete outcome data (attrition bias) High risk

$>20 \%$ loss to follow-up. 
Hakimi 1999 (Continued)

\begin{tabular}{|c|c|c|}
\hline Selective reporting (reporting bias) & Unclear risk & The protocol of this study is not available. \\
\hline Other bias & High risk & $\begin{array}{l}\text { Of note this information is from a draft of } \\
\text { a publication which was not published in } \\
\text { any peer review journal. However, } 2 \text { fol- } \\
\text { low-up studies using this original trial have } \\
\text { been published, Prawirohartono } 2011 \text { and } \\
\text { Prawirohartono } 2013 \text {. }\end{array}$ \\
\hline
\end{tabular}

Kirkwood 2010

\begin{tabular}{|c|c|c|}
\hline Methods & \multicolumn{2}{|c|}{ Cluster-randomised trial. } \\
\hline Participants & \multicolumn{2}{|c|}{$\begin{array}{l}\text { Inclusion criteria: women aged } 15 \text { to } 45 \text { years giving informed consent and who planned } \\
\text { to live in the trial area for at least } 3 \text { months were eligible for enrolment }\end{array}$} \\
\hline Interventions & \multicolumn{2}{|c|}{$\begin{array}{l}\text { Intervention group: } 104,484 \text { women in } 544 \text { clusters received weekly vitamin A capsule } \\
\text { consisted of } 25,000 \mathrm{IU} \text { ( } 7500 \mathrm{ug} \text { ) retinol equivalents (equivalent to } 25,000 \mathrm{IU} \text { vitamin } \\
\text { A) in soybean oil in a dark red opaque soft gel for } 12 \text { weeks } \\
\text { Control group: } 103,297 \text { women in } 542 \text { clusters received placebo capsule consisted of } \\
\text { soybean oil only }\end{array}$} \\
\hline Outcomes & \multicolumn{2}{|c|}{$\begin{array}{l}\text { Primary outcome: maternal mortality and all-cause female mortality } \\
\text { Other outcomes: maternal morbidity, perinatal and neonatal mortality (the number of } \\
\text { deaths during the first } 28 \text { completed days of life per } 1000 \text { live births in a given year or } \\
\text { period) }\end{array}$} \\
\hline Notes & \multicolumn{2}{|c|}{$\begin{array}{l}\text { Setting: } 7 \text { districts in Brong Ahafo region in Ghana. } \\
\text { Sample size: more that } 207,000 \text { pregnant women. }\end{array}$} \\
\hline \multicolumn{3}{|l|}{ Risk of bias } \\
\hline Bias & Authors' judgement & Support for judgement \\
\hline $\begin{array}{l}\text { Random sequence generation (selection } \\
\text { bias) }\end{array}$ & Low risk & "A computer-generated randomisation list." \\
\hline Allocation concealment (selection bias) & Low risk & "The capsules were packaged in labelled jars." \\
\hline $\begin{array}{l}\text { Blinding of participants and personnel } \\
\text { (performance bias) } \\
\text { All outcomes }\end{array}$ & Low risk & Participants and personnel "Double blind". \\
\hline $\begin{array}{l}\text { Blinding of outcome assessment (detection } \\
\text { bias) } \\
\text { All outcomes }\end{array}$ & Unclear risk & No information given. \\
\hline
\end{tabular}


Kirkwood 2010 (Continued)

\begin{tabular}{|l|l|l}
$\begin{array}{l}\text { Incomplete outcome data (attrition bias) } \\
\text { All outcomes }\end{array}$ & Low risk & $\begin{array}{l}44 \% \text { of enrolled women initially reported as loss to follow- } \\
\text { up: } 1 \% \text { withdrew consent, } 43 \% \text { moved. However, supple- } \\
\text { mentary information provided by authors in February 2011 } \\
\text { at the time of more detailed analysis reported overall loss to } \\
\text { follow-up for analysis for pregnancy-related mortality anal- } \\
\text { ysis as } 8 \% \text { : } 4657 \text { pregnancies excluded because outcome not } \\
\text { known (with } 2340 \text { in vitamin A arm and } 2317 \text { in placebo } \\
\text { arm). } 4192 \text { pregnancies excluded because status of woman } \\
\text { at } 42 \text { days not known (2174 vitamin A; 2018 placebo). Be- } \\
\text { fore these exclusions, the total number of pregnancies cap- } \\
\text { tured was } 111,801 \text {; after exclusions, the total number of } \\
\text { pregnancies with a known outcome was } 102,952\end{array}$ \\
\hline Selective reporting (reporting bias) & Unclear risk & The study protocol is not available. \\
\hline Other bias & Low risk & No other bias awarded. \\
\hline
\end{tabular}

Kumwenda 2002

\begin{tabular}{l|l}
\hline Methods & RCT. \\
\hline Participants & $\begin{array}{l}\text { Inclusion criteria: } \\
\bullet\end{array}$ \\
& $\begin{array}{l}\text { - HIV-pregnant women of 18-28 weeks' gestation; } \\
\end{array}$ \\
\hline
\end{tabular}

Interventions

Intervention group: 340 women received daily doses of orally administered vitamin A (3 mg retinol equivalent $(10,000 \mathrm{IU}$ of vitamin $\mathrm{A})+$ iron and folate for minimum of 12 weeks. Oral vitamin A (30 mg retinol equivalent) at 6 weeks' postpartum

Control group: 357 women received daily doses of iron (30 $\mathrm{mg}$ of elemental iron) and folate ( $400 \mathrm{mg}$ ) from the time of study enrolment until delivery. Oral vitamin A (30 mg retinol equivalent) at 6 weeks postpartum

Outcomes

Primary outcome: maternal vitamin A levels in blood and breast milk and HIV transmission in mother and baby

Other outcomes: $\mathrm{Hb}$ and birthweight.

$\begin{array}{ll}\text { Notes } & \text { Vitamin A levels were measured before starting supplementation } \\ & \text { Country: Malawi. } \\ & \text { Study setting: Queen Elizabeth Central Hospital (Blantyre, Malawi) }\end{array}$

Risk of bias

Bias

Authors' judgement Support for judgement

Random sequence generation (selection Low risk bias) 
Kumwenda 2002 (Continued)

\begin{tabular}{l|l|l}
\hline $\begin{array}{l}\text { Allocation concealment (selection bias) } \\
\text { Blinding of participants and personnel } \\
\text { (performance bias) } \\
\text { All outcomes }\end{array}$ & Low risk & $\begin{array}{l}\text { "pre packing study supplements in sequentially numbered series } \\
\text { assigned to study identification numbers." }\end{array}$ \\
\hline $\begin{array}{l}\text { Blinding of outcome assessment (detection } \\
\text { bias) } \\
\text { All outcomes }\end{array}$ & Unclear risk & No information given. \\
\hline $\begin{array}{l}\text { Incomplete outcome data (attrition bias) } \\
\text { All outcomes }\end{array}$ & Low risk & $\begin{array}{l}63 \text { (9\%) women were excluded from the analysis: } 57 \text { moved out, } \\
6 \text { could not be located }\end{array}$ \\
\hline $\begin{array}{l}\text { Selective reporting (reporting bias) } \\
\text { Other bias }\end{array}$ & Unclear risk & The protocol of the study is not available at the moment. \\
\hline
\end{tabular}

Muslimatun 2001

\begin{tabular}{|c|c|c|}
\hline Methods & \multicolumn{2}{|c|}{ A randomised double-blind community-based trial. } \\
\hline Participants & \multicolumn{2}{|c|}{ Inclusion criteria: 16 to 20 weeks pregnant, aged $17-35$ years and parity $<6$} \\
\hline Interventions & \multicolumn{2}{|c|}{$\begin{array}{l}\text { Intervention group: } 122 \text { women received each week from enrolment until delivery } 2 \\
\text { tablets each of which contained } 3000 \mathrm{RE} \text { vitamin A in addition to the ferrous sulphate and } \\
\text { folic acid. So intervention was } 6000 \mathrm{RE} \text { vitamin A ( } 20,000 \mathrm{IU}) \text { weekly for a minimum } \\
\text { of } 16 \text { weeks } \\
\text { Control group: } 121 \text { women received each week from enrolment until delivery } 2 \text { tablets } \\
\text { each containing } 60 \mathrm{mg} \text { elemental iron as ferrous sulphate and } 250 \mathrm{mg} \text { folic acid }\end{array}$} \\
\hline Outcomes & \multicolumn{2}{|c|}{$\begin{array}{l}\text { Primary outcome: infant growth in } 1 \text { year of life. } \\
\text { Other outcomes: maternal } \mathrm{Hb} \text { and fetal morbidity. }\end{array}$} \\
\hline Notes & \multicolumn{2}{|c|}{$\begin{array}{l}\text { Vitamin A levels were measured before starting supplementation } \\
\text { Country: Indonesia. } \\
\text { Study setting: } 9 \text { villages in the rural subdistrict of Leuwiliang, West Java, Indonesia }\end{array}$} \\
\hline \multicolumn{3}{|l|}{ Risk of bias } \\
\hline Bias & Authors' judgement & Support for judgement \\
\hline $\begin{array}{l}\text { Random sequence generation (selection } \\
\text { bias) }\end{array}$ & Unclear risk & “Assigned randomly." \\
\hline Allocation concealment (selection bias) & Unclear risk & No information provided. \\
\hline
\end{tabular}


All outcomes

Incomplete outcome data (attrition bias) High risk All outcomes
No information given.

\begin{tabular}{|c|c|c|}
\hline & & $\begin{array}{l}\text { gave birth to a stillborn child, } 1 \text { had twins } \\
\text { (only } 1 \text { survived), } 7 \text { had infants who died } \\
\text { before reaching } 3 \text { months of age and } 11 \\
\text { moved from the research area. Among the } \\
\text { remaining } 201 \text { eligible participants, } 182 \\
\text { participants attended the postpartum ex- } \\
\text { amination. Overall, the loss to follow-up of } \\
\text { the intervention group was } 32.8 \% \text { and the } \\
\text { control group was } 27.3 \%\end{array}$ \\
\hline Selective reporting (reporting bias) & Unclear risk & $\begin{array}{l}\text { The protocol of the study is not available } \\
\text { at the moment. }\end{array}$ \\
\hline Other bias & Low risk & Not aware of any other bias. \\
\hline
\end{tabular}

Radhika 2003

Methods

Participants "double-blinded, randomized, controlled study."

Inclusion criteria:

- 16 and 24 weeks' gestation;

- willing to have a follow-up every 2 weeks and who resided in the city area were chosen for the study.

Exclusion criteria: women with recurrent pregnancy loss or earlier preterm delivery and those with diabetes, hypertension, or any other metabolic disorder

Intervention group: 85 women received red palm oil providing 2173 to $2307 \mu$ g of $\beta$ carotene per day with a dosage schedule of 1 sachet per day $(8 \mathrm{~mL})$, which provided $91 \%$ to $96 \%$ of the daily requirement of vitamin A in pregnancy, (i.e. $2400 \mu \mathrm{g}$ of $\beta$-carotene which is equivalent to $3000 \mathrm{IU}$ of vitamin A) daily for a period of 8 weeks

Control group: 85 women received 1 sachet of groundnut oil $(8 \mathrm{~mL})$ for a period of 8 weeks

Outcomes

Primary outcome: maternal and neonatal vitamin A status.

Other outcomes: $\mathrm{Hb}$ levels in mother and baby, preterm birth (delivery less than 37 completed weeks as confirmed by ultrasound examination), birthweight and gestational age 
Radhika 2003 (Continued)

\begin{tabular}{|c|c|c|}
\hline Notes & \multicolumn{2}{|c|}{$\begin{array}{l}\text { Vitamin A levels were measured before starting supplementation } \\
\text { Country: India. } \\
\text { Study setting: the outpatient department of Niloufer Hospital, Hyderabad, India }\end{array}$} \\
\hline \multicolumn{3}{|l|}{ Risk of bias } \\
\hline Bias & Authors' judgement & Support for judgement \\
\hline $\begin{array}{l}\text { Random sequence generation (selection } \\
\text { bias) }\end{array}$ & Unclear risk & No information provided. \\
\hline Allocation concealment (selection bias) & Unclear risk & No information provided. \\
\hline $\begin{array}{l}\text { Blinding of participants and personnel } \\
\text { (performance bias) } \\
\text { All outcomes }\end{array}$ & Low risk & Participants and personnel "Double blind". \\
\hline $\begin{array}{l}\text { Blinding of outcome assessment (detection } \\
\text { bias) } \\
\text { All outcomes }\end{array}$ & Unclear risk & No information given. \\
\hline $\begin{array}{l}\text { Incomplete outcome data (attrition bias) } \\
\text { All outcomes }\end{array}$ & Low risk & $\begin{array}{l}41(24.1 \%) \text { women were excluded from the } \\
\text { analysis: } 23 \text { were not available for supple- } \\
\text { mentation, while } 18 \text { dropped out after ini- } \\
\text { tiating supplementation } \\
\text { Overall, the loss to follow-up of the inter- } \\
\text { vention group was } 9.5 \% \text { and the control } \\
\text { group was } 15.1 \%\end{array}$ \\
\hline Selective reporting (reporting bias) & Unclear risk & $\begin{array}{l}\text { The protocol of the study is not available } \\
\text { at the moment. }\end{array}$ \\
\hline Other bias & Low risk & No other bias awarded. \\
\hline
\end{tabular}

Semba 2001

\begin{tabular}{|c|c|}
\hline Methods & A randomised, double-blind, controlled clinical trial. \\
\hline Participants & $\begin{array}{l}\text { Inclusion criteria: } \\
\text { - pregnant women; } \\
\text { - } 18-28 \text { weeks' gestation; } \\
\text { - HIV-negative women. }\end{array}$ \\
\hline
\end{tabular}

Interventions

Intervention group: 109 women received daily supplement containing iron $(30 \mathrm{mg}$ elemental iron), folate ( $400 \mathrm{mg})$, and vitamin A (3000 $\mu \mathrm{g}$ retinol equivalent, which is $10,000 \mathrm{IU}$ of vitamin A) until delivery for a minimum of 8 weeks

Control group: 94 women received daily supplement containing iron $(30 \mathrm{mg})$ and folate (400 mg) until delivery 
Semba 2001 (Continued)

\begin{tabular}{ll} 
Outcomes & $\begin{array}{l}\text { Primary outcome: Hb concentrations and plasma erythropoietin concentrations } \\
\text { Other outcomes: levels of ferritin, ? 1-acid glycoprotein, CRP and plasma vitamin A }\end{array}$ \\
\hline \multirow{2}{*}{ Notes } & Vitamin A levels were measured before starting supplementation \\
& Country: Malawi. \\
& Study setting: the Queen Elizabeth Central Hospital in Blantyre, Malawi \\
& Semba 2001 is linked to the Semba 2000 trial; the difference being that Semba 2000 \\
& investigated slightly different outcomes in HIV-positive women and Semba 2001 assessed \\
& HIV negative women.
\end{tabular}

Risk of bias

\begin{tabular}{llll}
\hline Bias & Authors' judgement & Support for judgement \\
\hline $\begin{array}{l}\text { Random sequence generation (selection } \\
\text { bias) }\end{array}$ & Low risk & "a computer random-number generator." \\
\hline $\begin{array}{l}\text { Allocation concealment (selection bias) } \\
\text { Blinding of participants and personnel } \\
\text { (performance bias) } \\
\text { All outcomes }\end{array}$ & Low risk & "sequentially numbered opaque bottle." \\
\hline $\begin{array}{l}\text { Blinding of outcome assessment (detection } \\
\text { bias) } \\
\text { All outcomes }\end{array}$ & Unclear risk & Participants and personnel "Double blind". \\
\hline $\begin{array}{l}\text { Incomplete outcome data (attrition bias) } \\
\text { All outcomes }\end{array}$ & High risk & No information given. \\
\hline $\begin{array}{l}\text { Selective reporting (reporting bias) } \\
\text { Other bias }\end{array}$ & Unclear risk & $\begin{array}{l}\text { 66 (32.5\%) women were excluded from the } \\
\text { analysis: } 42 \text { missed the study visit, } 9 \text { did not } \\
\text { have their Hb analysed, 15 moved out }\end{array}$ \\
\hline
\end{tabular}

Suharno 1993

\begin{tabular}{l|l}
\hline Methods & Double-blinded RCT. \\
\hline Participants & Inclusion criteria: \\
& $\bullet$ middle and low socioeconomic; \\
& - $16-24$ weeks pregnant; \\
& $\bullet 17-35$ years old; \\
& $\bullet$ parity $0-4 ;$ \\
& $\bullet$ Hb $80-109 \mathrm{~g} / \mathrm{L}$.
\end{tabular}


Suharno 1993 (Continued)

\begin{tabular}{|c|c|c|}
\hline Interventions & \multicolumn{2}{|c|}{$\begin{array}{l}\text { Intervention group 1: } 63 \text { women received vitamin A ( } 2.4 \mathrm{mg} \text { retinol as retinyl palmitate) } \\
\text { (equivalent to } 8000 \mathrm{IU} \text { of vitamin } \mathrm{A} \text { ) and placebo iron tablets daily for } 8 \text { weeks } \\
\text { Intervention group 2: } 63 \text { women received iron tablets ( } 60 \mathrm{mg} \text { ferrous sulphate) and } \\
\text { placebo vitamin A daily for } 8 \text { weeks } \\
\text { Intervention group 3: } 63 \text { women received vitamin A and iron daily for } 8 \text { weeks } \\
\text { Control group: } 62 \text { women received both placebo daily for } 8 \text { weeks }\end{array}$} \\
\hline Outcomes & \multicolumn{2}{|c|}{ Maternal anaemia indices. } \\
\hline Notes & \multicolumn{2}{|c|}{$\begin{array}{l}\text { Vitamin A levels were measured before starting supplementation } \\
\text { Country: Indonesia. } \\
\text { Study setting: rural villages in } 3 \text { subdistricts of Bogo, West Java }\end{array}$} \\
\hline \multicolumn{3}{|l|}{ Risk of bias } \\
\hline Bias & Authors' judgement & Support for judgement \\
\hline $\begin{array}{l}\text { Random sequence generation (selection } \\
\text { bias) }\end{array}$ & Unclear risk & “randomly." \\
\hline Allocation concealment (selection bias) & Low risk & 'An independent researcher randomly labelled' the preparations \\
\hline $\begin{array}{l}\text { Blinding of participants and personnel } \\
\text { (performance bias) } \\
\text { All outcomes }\end{array}$ & Low risk & Participants and personnel "Double blind". \\
\hline $\begin{array}{l}\text { Blinding of outcome assessment (detection } \\
\text { bias) } \\
\text { All outcomes }\end{array}$ & Unclear risk & No information given. \\
\hline $\begin{array}{l}\text { Incomplete outcome data (attrition bias) } \\
\text { All outcomes }\end{array}$ & Low risk & $\begin{array}{l}54(17 \%) \text { women were excluded from the analysis: } 11 \text { moved, } \\
23 \text { taken supplement less than } 8 \text { weeks, } 10 \text { refused blood sam- } \\
\text { ple, } 10 \text { not available for } 2^{\text {nd }} \text { blood sample. }\end{array}$ \\
\hline Selective reporting (reporting bias) & Unclear risk & The protocol of the study is not available at the moment. \\
\hline Other bias & Low risk & No other bias awarded. \\
\hline
\end{tabular}

Sun 2010

Methods

Double-blind RCT.

Participants

Inclusion criteria:

- anaemic $(\mathrm{Hb}>80$ but $<110 \mathrm{~g} / \mathrm{L})$;

- pregnant women, 12-24 weeks' gestation, age between 20-30 years;

- no dietary supplements during previous 2 months;

- no abnormal pregnancy response. 
Sun 2010 (Continued)

\begin{tabular}{|c|c|c|}
\hline Interventions & \multicolumn{2}{|c|}{$\begin{array}{l}4 \text { groups: } \\
\text { - group } 1(\mathrm{n}=47) \text { was supplemented daily with } 60 \mathrm{mg} \text { iron as ferrous sulphate; } \\
\text { - group } 2(\mathrm{n}=46) \text { with } 60 \mathrm{mg} \text { and } 0.4 \mathrm{mg} \text { folic acid; } \\
\text { - group } 3(\mathrm{n}=46) \text { with } 60 \mathrm{mg} \text { iron, } 2.0 \mathrm{mg} \text { retinol and } 0.4 \mathrm{mg} \text { folic acid; } \\
\text { - group } 4(\mathrm{n}=47) \text { was the placebo control group. }\end{array}$} \\
\hline Outcomes & \multicolumn{2}{|c|}{$\begin{array}{l}\text { Primary outcomes: } \\
\text { - iron status; } \\
\text { - Cytokine Interleukin -2 (IL -2) levels; } \\
\text { - Lymphocyte proliferation. }\end{array}$} \\
\hline Notes & \multicolumn{2}{|c|}{$\begin{array}{l}\text { Short intervention time of } 2 \text { months duration. } \\
\text { Patient were recruited between March } 2004 \text { - September } 2005 \text {. } \\
\text { Setting: Shen county in a central rural area of China. } \\
\text { Total number of patients - } 186 .\end{array}$} \\
\hline \multicolumn{3}{|l|}{ Risk of bias } \\
\hline Bias & Authors' judgement & Support for judgement \\
\hline $\begin{array}{l}\text { Random sequence generation (selection } \\
\text { bias) }\end{array}$ & High risk & "Patients were randomised in order of enrolment." \\
\hline Allocation concealment (selection bias) & High risk & "Patients were randomised in order of enrolment." \\
\hline $\begin{array}{l}\text { Blinding of participants and personnel } \\
\text { (performance bias) } \\
\text { All outcomes }\end{array}$ & Low risk & Adequate blinding of participants and personnel reported. \\
\hline $\begin{array}{l}\text { Blinding of outcome assessment (detection } \\
\text { bias) } \\
\text { All outcomes }\end{array}$ & Unclear risk & No details given. \\
\hline $\begin{array}{l}\text { Incomplete outcome data (attrition bias) } \\
\text { All outcomes }\end{array}$ & Low risk & $\begin{array}{l}\text { Loss of participants }<5 \%-6 \text { women did not complete the } \\
\text { trial due to moving to other villages (3), and stopped taking } \\
\text { supplements during the trial (3) }\end{array}$ \\
\hline Selective reporting (reporting bias) & Unclear risk & No details given. \\
\hline Other bias & Unclear risk & No details given. \\
\hline
\end{tabular}




\begin{tabular}{|c|c|}
\hline Methods & Quasi-RCT. A double-blind, placebo, controlled trial. \\
\hline Participants & $\begin{array}{l}\text { Inclusion criteria: } \\
\text { - aged less than } 35 \text { years; } \\
\text { - between } 13 \text { and } 28 \text { weeks' gestation; } \\
\text { - single pregnancy; } \\
\text { - in good health; } \\
\text { - anaemia }(\mathrm{Hb}<11.0 \mathrm{~g} / \mathrm{dL}) \text {. } \\
\text { Exclusion criteria: } \\
\text { - pregnant women with pre-eclampsia, congestive heart disease, tuberculosis and } \\
\text { acute infections; } \\
\text { - women in the first trimester of pregnancy. }\end{array}$ \\
\hline Interventions & $\begin{array}{l}\text { Intervention group 1: } 22 \text { women; group IFR received iron-folate tablets }+5 \mathrm{mg} \text { riboflavin } \\
7 \text { days a week for } 60 \text { days } \\
\text { Intervention group 2: } 29 \text { women; group IFA received iron-folate tablets }+2.75 \mathrm{mg} \text { retinyl } \\
\text { palmitate (equal to } 5000 \mathrm{IU} \text { vitamin A) } 7 \text { days a week for } 60 \text { days } \\
\text { Intervention group 3: } 23 \text { women; group IFRA received iron-folate tablets }+5 \mathrm{mg} \text { ri- } \\
\text { boflavin }+2.75 \mathrm{mg} \text { retinyl palmitate } 7 \text { days a week for } 60 \text { days } \\
\text { Control group: } 29 \text { women; group IF received iron-folate tablets }+5 \mathrm{mg} \text { glucose } 7 \text { days } \\
\text { a week for } 60 \text { days }\end{array}$ \\
\hline Outcomes & Maternal levels of vitamin A and riboflavin. \\
\hline Notes & $\begin{array}{l}\text { Vitamin A levels were measured before starting supplementation } \\
\text { Country: Indonesia. } \\
\text { Study setting: health centre ANC. }\end{array}$ \\
\hline
\end{tabular}

\section{Risk of bias}

\begin{tabular}{|c|c|c|}
\hline Bias & Authors' judgement & Support for judgement \\
\hline $\begin{array}{l}\text { Random sequence generation (selection } \\
\text { bias) }\end{array}$ & High risk & “allocated alternately." \\
\hline Allocation concealment (selection bias) & High risk & “allocated alternately." \\
\hline $\begin{array}{l}\text { Blinding of participants and personnel } \\
\text { (performance bias) } \\
\text { All outcomes }\end{array}$ & Low risk & "participants and personnel double-blind. \\
\hline $\begin{array}{l}\text { Blinding of outcome assessment (detection } \\
\text { bias) } \\
\text { All outcomes }\end{array}$ & Unclear risk & Information not given. \\
\hline $\begin{array}{l}\text { Incomplete outcome data (attrition bias) } \\
\text { All outcomes }\end{array}$ & Low risk & $\begin{array}{l}19(18.4 \%) \text { were excluded from the analy- } \\
\text { ses: } 9 \text { premature labour, } 1 \text { stillbirth, } 1 \text { mi- } \\
\text { gration, } 1 \text { refusal to give blood, } 2 \text { nausea } \\
\text { and vomiting and } 5 \text { incorrect dates given }\end{array}$ \\
\hline
\end{tabular}


Suprapto 2002 (Continued)

for last menstruation but with normal deliveries

\begin{tabular}{|c|c|c|}
\hline Selective reporting (reporting bias) & Unclear risk & $\begin{array}{l}\text { The protocol of the study is not available } \\
\text { at the moment. }\end{array}$ \\
\hline Other bias & High risk & $\begin{array}{l}\text { Women in group IFRA were shorter and } \\
\text { lighter than those in other groups }\end{array}$ \\
\hline
\end{tabular}

Tanumihardjo 2002

\begin{tabular}{|c|c|}
\hline Methods & RCT. \\
\hline Participants & $\begin{array}{l}\text { Inclusion criteria: } \\
\text { - pregnant women in the second or early third trimester; } \\
\text { - } 18 \text { to } 37 \text { years old; } \\
\text { - parity from } 0 \text { to } 4 \text { children. }\end{array}$ \\
\hline Interventions & $\begin{array}{l}\text { Intervention group 1: } 5 \text { women received } 1.07 \mathrm{mmol}(60 \mathrm{mg}) \text { ferrous sulphate with a } \\
\text { vitamin A placebo daily for } 8 \text { weeks } \\
\text { Intervention group 2: } 8 \text { women received vitamin A plus iron. } \\
\text { Intervention group 3: } 7 \text { women received } 8.4 \mu \mathrm{mol}(8000 \mathrm{IU}) \text { vitamin A as retinyl palmi- } \\
\text { tate with an iron placebo } \\
\text { Control group: } 7 \text { women received placebo. }\end{array}$ \\
\hline Outcomes & Maternal $\mathrm{Hb}$ and retinol levels. \\
\hline Notes & $\begin{array}{l}\text { Vitamin A levels were measured before starting supplementation } \\
\text { Country: Indonesia. } \\
\text { Study setting: local health posts the suburban areas of Bogor in West Java }\end{array}$ \\
\hline
\end{tabular}

\section{Risk of bias}

Bias

Authors' judgement Support for judgement

Random sequence generation (selection Unclear risk No information provided.

bias)

Allocation concealment (selection bias) Unclear risk No information provided.

Blinding of participants and personnel Low risk (performance bias)

"Subjects and village volunteers were unaware of group assignment."

All outcomes

Blinding of outcome assessment (detection Unclear risk bias)

No information provided.

All outcomes 
Tanumihardjo 2002 (Continued)

\begin{tabular}{l|l|l}
\hline $\begin{array}{l}\text { Incomplete outcome data (attrition bias) } \\
\text { All outcomes }\end{array}$ & Low risk & No loss of follow-up reported. \\
\hline Selective reporting (reporting bias) & Unclear risk & The protocol of the study is not available at the moment. \\
\hline Other bias & Unclear risk & Not enough information provided. \\
\hline
\end{tabular}

van den Broek 2006

\begin{tabular}{|c|c|}
\hline Methods & RCT. \\
\hline Participants & $\begin{array}{l}\text { Inclusion criteria: } \\
\text { - }(\mathrm{Hb})<11.0 \mathrm{~g} / \mathrm{dl} \text { by HemoCue screening method at first antenatal visit; } \\
\text { - singleton pregnancy with gestational age }>12 \text { weeks and }<24 \text { weeks measured by } \\
\text { ultrasound scan; } \\
\text { - no fetal abnormality detectable by ultrasound at time of booking; } \\
\text { - residing in the catchment area of the health centre; } \\
\text { - signed informed consent. } \\
\text { Exclusion criteria: twin pregnancy. }\end{array}$ \\
\hline
\end{tabular}

Interventions

Intervention group 1: 234 women; $5000 \mathrm{IU}$ vitamin A and iron tablets daily (60 mg elemental iron as ferrous sulphate with $0.25 \mathrm{mg}$ folic acid) and antimalarial prophylaxis as 2 doses of Fansidar (500 mg sulphadoxine with $25 \mathrm{mg}$ pyrimethamine. Tablets given daily from enrolment till delivery minimum of 8 weeks

Intervention group 2: 234 women; 10,000 IU vitamin A and iron tablets daily (60 mg elemental iron as ferrous sulphate with $0.25 \mathrm{mg}$ folic acid) and antimalarial prophylaxis as 2 doses of Fansidar ( $500 \mathrm{mg}$ sulphadoxine with $25 \mathrm{mg}$ pyrimethamine)

Control group: 232 women; placebo and iron tablets daily $(60 \mathrm{mg}$ elemental iron as ferrous sulphate with $0.25 \mathrm{mg}$ folic acid) and antimalarial prophylaxis as 2 doses of Fansidar (500 mg sulphadoxine with $25 \mathrm{mg}$ pyrimethamine

Outcomes

Primary outcome: Hb concentrations and anaemia.

Other outcomes: iron status, preterm birth (delivery less than 37 completed weeks as confirmed by ultrasound examination), markers of infections included CRP, malaria parasitaemia and HIV status

Notes

Vitamin A levels were measured before starting supplementation

Country: Malawi.

Study setting: rural southern Malawi attending ANC at Health Centres

Risk of bias

Bias

Authors' judgement Support for judgement

Random sequence generation (selection Low risk bias) 
van den Broek 2006 (Continued)

\begin{tabular}{|c|c|c|}
\hline Allocation concealment (selection bias) & Low risk & "consecutive numbers" "in sealed envelopes." \\
\hline $\begin{array}{l}\text { Blinding of participants and personnel } \\
\text { (performance bias) } \\
\text { All outcomes }\end{array}$ & Low risk & $\begin{array}{l}\text { "The supplements in vitamin A and placebo treatments allocated } \\
\text { were prepared in identical capsules." }\end{array}$ \\
\hline $\begin{array}{l}\text { Blinding of outcome assessment (detection } \\
\text { bias) } \\
\text { All outcomes }\end{array}$ & Low risk & $\begin{array}{l}\text { "The supplements in vitamin A and placebo treatments allocated } \\
\text { were prepared in identical capsules." }\end{array}$ \\
\hline $\begin{array}{l}\text { Incomplete outcome data (attrition bias) } \\
\text { All outcomes }\end{array}$ & Low risk & $\begin{array}{l}96(13.7 \%) \text { women were excluded from the analyses: } 18 \text { women } \\
\text { moved out from the area, } 68 \text { declined to continue, } 10 \text { missed } \\
\text { appointment }\end{array}$ \\
\hline Selective reporting (reporting bias) & Unclear risk & The protocol of the study is not available at the moment. \\
\hline Other bias & Low risk & Not aware of other bias. \\
\hline
\end{tabular}

\section{West 1999}

\begin{tabular}{|c|c|}
\hline Methods & Double-blind cluster RCT. \\
\hline Participants & $\begin{array}{l}\text { Inclusion criteria: } \\
\text { - women of childbearing age who were married and living with their husbands; } \\
\text { - newly married women. } \\
\text { Exclusion criteria: women who were already married who had moved into study wards }\end{array}$ \\
\hline Interventions & $\begin{array}{l}\text { Intervention group } 1: 15,305 \text { women in } 90 \text { wards received opaque, gelatinous capsules } \\
\text { containing peanut oil and } 23,300 \mathrm{IU} \text { of preformed vitamin A ( } 7000 \mu \mathrm{g} \text { retinol equiva- } \\
\text { lents) as retinyl palmitate weekly for a minimum of } 12 \text { weeks } \\
\text { Intervention group 2: } 14,536 \text { women in } 90 \text { wards received } 42 \mathrm{mg} \text { of all trans-b carotene } \\
\text { ( } 7000 \mu \mathrm{g} \text { retinol equivalents, assuming a conversion ratio to retinol of } 6 \text { to } 1 \text { after uptake) } \\
\text { weekly } \\
\text { Control group: } 14,805 \text { women in } 90 \text { wards received no vitamin A or b carotene (placebo) } \\
\text { weekly }\end{array}$ \\
\hline
\end{tabular}

Outcomes

Primary outcome: mortality of mother and baby (the number of deaths during the first 28 completed days of life per 1000 live births in a given year or period)

Other outcomes: maternal vitamin A and retinol levels, and maternal morbidity

Notes

Vitamin A levels were not measured before starting supplementation

Country: Nepal.

Study setting: 270 wards in 30 subdistricts.

\section{Risk of bias}


West 1999 (Continued)

\begin{tabular}{|c|c|c|}
\hline $\begin{array}{l}\text { Random sequence generation (selection } \\
\text { bias) }\end{array}$ & Low risk & $\begin{array}{l}\text { "All wards were assigned in Kathmandu by a random } \\
\text { draw of numbered chits, blocked on subdistrict, for eligi- } \\
\text { ble women to receive one of three identical coded supple- } \\
\text { ments." }\end{array}$ \\
\hline Allocation concealment (selection bias) & Low risk & "three identical coded supplements." \\
\hline $\begin{array}{l}\text { Blinding of participants and personnel } \\
\text { (performance bias) } \\
\text { All outcomes }\end{array}$ & Low risk & Participants and personnel "double-blind”. \\
\hline $\begin{array}{l}\text { Blinding of outcome assessment (detection } \\
\text { bias) } \\
\text { All outcomes }\end{array}$ & Unclear risk & Details not included. \\
\hline $\begin{array}{l}\text { Incomplete outcome data (attrition bias) } \\
\text { All outcomes }\end{array}$ & Low risk & $\begin{array}{l}1136(2.5 \%) \text { women were excluded because they emi- } \\
\text { grated before becoming pregnant or dying or because they } \\
\text { declined to be recruited. } 157 \text { women were lost to follow- } \\
\text { up during the postpartum period (their median follow-up } \\
\text { time postpartum was around } 2 \text { weeks in each group) }\end{array}$ \\
\hline Selective reporting (reporting bias) & Unclear risk & The protocol of the study is not available at the moment. \\
\hline Other bias & Low risk & No other bias awarded. \\
\hline
\end{tabular}

West 2011

Methods

Double-blind cluster-randomised placebo-controlled trial.

Participants

Inclusion criteria:

all married women of reproductive age (13-45 years of age) were under surveillance living in the study settings and all who became pregnant were included in this study

Exclusion criteria:

$>$ first trimester of pregnancy;

women who during surveillance:

- permanently moved outside study settings;

- became menopausal;

- were sterilised;

- who died;

- whose husbands died.

Sample size: 60,294.

Interventions

$7000 \mathrm{ug}$ of retinol equivalent as retinyl palmitate, $42 \mathrm{mg}$ of all-trans beta-carotene or placebo

Outcomes

Primary outcome: all-cause mortality of women related to pregnancy, stillbirth, and infant mortality up to 12 weeks ( 84 days) following pregnancy outcome 
West 2011 (Continued)

\begin{tabular}{ll}
\hline Notes & Vitamin A levels were not measured before starting supplementation \\
Country: Bangladesh. & Duration: $2001-2007$ termed the JiVitA-1 trial. \\
& Study setting: 596 sectors in the rural northwestern district of Gaibandha and Rangpur \\
between 2001 and 2007 & Christian 2013 is a follow-up study of this trials that describes secondary outcomes of \\
& interest (low birthweight and preterm birth) in this review \\
\hline
\end{tabular}

Risk of bias

\begin{tabular}{|c|c|c|}
\hline Bias & Authors' judgement & Support for judgement \\
\hline $\begin{array}{l}\text { Random sequence generation (selection } \\
\text { bias) }\end{array}$ & Low risk & $\begin{array}{l}\text { "cluster randomization" "sectors were ran- } \\
\text { domized in blocks of nine, to one of three } \\
\text { codes - } 1,2,3 . " \\
\text { "field supervisor [were engaged] to in the } \\
\text { process of randomization to increase the } \\
\text { transparency of sector allocation." }\end{array}$ \\
\hline Allocation concealment (selection bias) & Low risk & $\begin{array}{l}\text { "three sets of } 3 \text { identical coins on which } \\
\text { the numbers } 1,2 \text { or } 3 \text { were written were } \\
\text { placed into a container, mixed and removed } \\
\text { randomly, without replacement and the } 3 \\
\text { digit code of each sector was read aloud } \\
\text { sequentially." }\end{array}$ \\
\hline $\begin{array}{l}\text { Blinding of participants and personnel } \\
\text { (performance bias) } \\
\text { All outcomes }\end{array}$ & Low risk & $\begin{array}{l}\text { "study participants, interviewers, field } \\
\text { supervisors, and investigators remained } \\
\text { masked to treatment assignments until the } \\
\text { end of the trial." }\end{array}$ \\
\hline $\begin{array}{l}\text { Blinding of outcome assessment (detection } \\
\text { bias) } \\
\text { All outcomes }\end{array}$ & Low risk & $\begin{array}{l}\text { "study participants, interviewers, field } \\
\text { supervisors, and investigators remained } \\
\text { masked to treatment assignments until the } \\
\text { end of the trial." }\end{array}$ \\
\hline $\begin{array}{l}\text { Incomplete outcome data (attrition bias) } \\
\text { All outcomes }\end{array}$ & Low risk & $\begin{array}{l}\text { Loss of participants }<5 \% \text {, except for out- } \\
\text { come of low birthweight, which was only } \\
\text { measured for less than } 36 \%\end{array}$ \\
\hline Selective reporting (reporting bias) & Low risk & Nil reported in the protocol. \\
\hline Other bias & Low risk & No other bias awarded. \\
\hline
\end{tabular}

ANC: antenatal clinic

CRP: C-reactive protein

Hb: haemoglobin

IU: international unit

Vitamin A supplementation during pregnancy for maternal and newborn outcomes (Review)

Copyright @ 2015 The Cochrane Collaboration. Published by John Wiley \& Sons, Ltd. 
LMP: last menstrual period

RCT: randomised controlled trial

RE: retinol equivalents

Characteristics of excluded studies [ordered by study ID]

\begin{tabular}{|c|c|}
\hline Study & Reason for exclusion \\
\hline Alam 2010 & The intervention did not include vitamin A. \\
\hline Banerjee 2009 & $\begin{array}{l}\text { Intervention uses lycopene which is a compound that lacks beta-ion ring (in the } \beta \text {-carotene), so lycopene cannot } \\
\text { form vitamin } A \text { and its biological effects are due to mechanism other than forming vitamin A }\end{array}$ \\
\hline Chawla 1995 & Not a randomised trial. \\
\hline Chikobvu 2001 & $\begin{array}{l}\text { Double-blind randomised trial with outcomes on HIV transmission and HIV complications, only abstract avail- } \\
\text { able }\end{array}$ \\
\hline Christian 2003 & Cluster-randomised trial with all arms of intervention containing vitamin A and no comparison for vitamin A \\
\hline Darboe 2007 & Intervention started after delivery. \\
\hline Haskell 2005 & Both arms of intervention containing vitamin $\mathrm{A}$ and no comparison for vitamin $\mathrm{A}$ \\
\hline Howells 1986 & Not a randomised trial. \\
\hline Humphrey 2006 & Intervention started after delivery. \\
\hline Laitinen 2009 & Not a randomised trial and vitamin A present in both arms of intervention \\
\hline Lietz 2001 & Both arms of intervention containing vitamin $\mathrm{A}$ and no comparison for vitamin $\mathrm{A}$ \\
\hline Roberfroid 2010 & Both arms of intervention containing iron and folic acid and no comparison for vitamin A \\
\hline Roy 1997 & Intervention started after delivery. \\
\hline Sharma 2003 & $\begin{array}{l}\text { Intervention uses lycopene which is a compound that lacks beta-ion ring (in the } \beta \text {-carotene), so lycopene cannot } \\
\text { form vitamin } A \text { and its biological effects are due to mechanism other than forming vitamin A }\end{array}$ \\
\hline Van Vliet 2001 & Participants are non-pregnant women. \\
\hline
\end{tabular}


Characteristics of ongoing studies [ordered by study ID]

Ahmad 2009

\begin{tabular}{|c|c|}
\hline Trial name or title & Vitamin A and maternal-infant flu vaccine response \\
\hline Methods & Placebo-controlled double-masked and randomised trial. \\
\hline Participants & $\begin{array}{l}\text { Inclusion criteria: } \\
\text { - female } 22-35 \text { years; } \\
\text { - mothers at the beginning of second trimester }-12 \text { weeks' gestation; } \\
\text { - willing to stay in Dhaka during pregnancy and willing to admit in the clinic at delivery. } \\
\text { Exclusion criteria: } \\
\text { - history of systemic disease; } \\
\text { - previous complicated pregnancies or of a preterm delivery; } \\
\text { - abortion; } \\
\text { - congenital anomaly; } \\
\text { - hypersensitivity to influenza vaccine or receipt of the vaccine. }\end{array}$ \\
\hline Interventions & Weekly 10,000 IU vitamin A or placebo. \\
\hline Outcomes & $\begin{array}{l}\text { Main outcomes: IgG cord blood plasma; vitamin A cord blood; plasma influenza IgG; colostrum vitamin A; } \\
\text { colostrum influenza sIgA } \\
\text { Other outcomes: } \\
\text { - mothers (6 months postpartum) serum vitamin A; } \\
\text { - serum influ IgG; } \\
\text { - breast milk vitamin A; } \\
\text { - Influ sIgA; } \\
\text { - infants (6 months) anthropometry; } \\
\text { - serum vitamin A; } \\
\text { - serum influ IgG; } \\
\text { - nasal Influ sIgA. }\end{array}$ \\
\hline Starting date & February 2009. \\
\hline Contact information & International Centre for Diarrhoeal Disease Research, Bangladesh \\
\hline Notes & $\begin{array}{l}66 \text { women randomised. } \\
\text { Setting: Dhaka, Bangladesh. } \\
3 \text { urban maternity clinics. } \\
2010 \text { - no results reported. }\end{array}$ \\
\hline
\end{tabular}

IgG: immunoglobulin G 
DATA ANDANALYSES

Comparison 1. Vitamin A alone versus placebo or no treatment

\begin{tabular}{lcclc} 
Outcome or subgroup title & $\begin{array}{c}\text { No. of } \\
\text { studies }\end{array}$ & $\begin{array}{c}\text { No. of } \\
\text { participants }\end{array}$ & \multicolumn{1}{c}{ Statistical method } & Effect size \\
\hline 1 Maternal mortality & 4 & & Risk Ratio (Random, 95\% CI) & $0.88[0.65,1.20]$ \\
2 Perinatal mortality & 1 & & Risk Ratio (Fixed, 95\% CI) & $1.01[0.95,1.07]$ \\
3 Neonatal mortality & 3 & & Risk Ratio (Fixed, 95\% CI) & $0.97[0.90,1.05]$ \\
4 Stillbirth & 2 & 122850 & Risk Ratio (M-H, Fixed, 95\% CI) & $1.04[0.98,1.10]$ \\
5 Maternal anaemia & 3 & & Risk Ratio (Random, 95\% CI) & $0.64[0.43,0.94]$ \\
6 Maternal clinical infection & 5 & & Risk Ratio (Random, 95\% CI) & $0.45[0.20,0.99]$ \\
7 Maternal night blindness & 2 & & Risk Ratio (Random, 95\% CI) & $0.79[0.64,0.98]$ \\
8 Preterm birth & 5 & 40137 & Risk Ratio (M-H, Fixed, 95\% CI) & $0.98[0.94,1.01]$ \\
9 Neonatal anaemia & 1 & 406 & Risk Ratio (M-H, Fixed, 95\% CI) & $0.99[0.92,1.08]$ \\
10 Neonatal clinical infection & 0 & 0 & Risk Ratio (M-H, Fixed, 95\% CI) & $0.0[0.0,0.0]$ \\
11 Congenital malformations & 0 & 0 & Risk Ratio (M-H, Fixed, 95\% CI) & $0.0[0.0,0.0]$ \\
12 Low birthweight & 4 & 14599 & Risk Ratio (M-H, Random, 95\% CI) & $1.02[0.89,1.16]$ \\
\hline
\end{tabular}

Comparison 2. Vitamin A alone versus micronutrient supplement without vitamin A

\begin{tabular}{lcclc} 
Outcome or subgroup title & $\begin{array}{c}\text { No. of } \\
\text { studies }\end{array}$ & $\begin{array}{c}\text { No. of } \\
\text { participants }\end{array}$ & Statistical method & Effect size \\
\hline 1 Maternal mortality & 0 & 0 & Risk Ratio (M-H, Fixed, 95\% CI) & $0.0[0.0,0.0]$ \\
2 Perinatal mortality & 0 & 0 & Risk Ratio (M-H, Fixed, 95\% CI) & $0.0[0.0,0.0]$ \\
3 Neonatal mortality & 0 & 0 & Risk Ratio (M-H, Fixed, 95\% CI) & $0.0[0.0,0.0]$ \\
4 Stillbirth & 0 & 0 & Risk Ratio (M-H, Fixed, 95\% CI) & $0.0[0.0,0.0]$ \\
5 Maternal anaemia & 0 & 0 & Risk Ratio (M-H, Fixed, 95\% CI) & $0.0[0.0,0.0]$ \\
6 Maternal clinical infection & 2 & 591 & Risk Ratio (M-H, Fixed, 95\% CI) & $0.99[0.83,1.18]$ \\
7 Maternal night blindness & 0 & 0 & Risk Ratio (M-H, Fixed, 95\% CI) & $0.0[0.0,0.0]$ \\
8 Preterm birth & 0 & 0 & Risk Ratio (M-H, Fixed, 95\% CI) & $0.0[0.0,0.0]$ \\
9 Neonatal anaemia & 0 & 0 & Risk Ratio (M-H, Fixed, 95\% CI) & $0.0[0.0,0.0]$ \\
10 Neonatal clinical infection & 0 & 0 & Risk Ratio (M-H, Fixed, 95\% CI) & $0.0[0.0,0.0]$ \\
11 Congenital malformations & 0 & 0 & Risk Ratio (M-H, Fixed, 95\% CI) & $0.0[0.0,0.0]$ \\
12 Low birthweight & 0 & 0 & Risk Ratio (M-H, Fixed, 95\% CI) & $0.0[0.0,0.0]$ \\
\hline
\end{tabular}

Vitamin A supplementation during pregnancy for maternal and newborn outcomes (Review) 


\begin{tabular}{lccll} 
Outcome or subgroup title & $\begin{array}{c}\text { No. of } \\
\text { studies }\end{array}$ & $\begin{array}{c}\text { No. of } \\
\text { participants }\end{array}$ & \multicolumn{1}{c}{ Statistical method } & Effect size \\
\hline 1 Maternal mortality & 0 & 0 & Risk Ratio (M-H, Fixed, 95\% CI) & $0.0[0.0,0.0]$ \\
2 Perinatal mortality & 1 & 179 & Risk Ratio (M-H, Fixed, 95\% CI) & $0.51[0.10,2.69]$ \\
3 Neonatal mortality & 1 & 594 & Risk Ratio (M-H, Fixed, 95\% CI) & $0.65[0.32,1.31]$ \\
4 Stillbirth & 2 & 866 & Risk Ratio (M-H, Fixed, 95\% CI) & $1.41[0.57,3.47]$ \\
5 Maternal anaemia & 3 & 706 & Risk Ratio (M-H, Fixed, 95\% CI) & $0.86[0.68,1.09]$ \\
6 Maternal clinical infection & 2 & 597 & Risk Ratio (M-H, Fixed, 95\% CI) & $0.95[0.80,1.13]$ \\
7 Maternal night blindness & 0 & 0 & Risk Ratio (M-H, Fixed, 95\% CI) & $0.0[0.0,0.0]$ \\
8 Preterm birth & 1 & 136 & Risk Ratio (M-H, Fixed, 95\% CI) & $0.39[0.08,1.93]$ \\
9 Neonatal anaemia & 2 & 1052 & Risk Ratio (M-H, Random, 95\% CI) & $0.75[0.38,1.51]$ \\
10 Neonatal clinical infection & 0 & 0 & Risk Ratio (M-H, Fixed, 95\% CI) & $0.0[0.0,0.0]$ \\
11 Congenital malformations & 1 & 179 & Risk Ratio (M-H, Fixed, 95\% CI) & $0.34[0.04,3.18]$ \\
12 Low birthweight & 1 & 594 & Risk Ratio (M-H, Fixed, 95\% CI) & $0.67[0.47,0.96]$ \\
\hline
\end{tabular}

\section{Comparison 4. Vitamin A alone versus placebo or no treatment (subgroups)}

\begin{tabular}{|c|c|c|c|c|}
\hline Outcome or subgroup title & $\begin{array}{l}\text { No. of } \\
\text { studies }\end{array}$ & $\begin{array}{c}\text { No. of } \\
\text { participants }\end{array}$ & Statistical method & Effect size \\
\hline $\begin{array}{l}1 \text { Perinatal mortality (infant } \\
\text { mortality level) }\end{array}$ & 1 & 76176 & Risk Ratio (M-H, Fixed, 95\% CI) & $1.01[0.95,1.07]$ \\
\hline $\begin{array}{l}\text { 1.1 Countries with low infant } \\
\text { mortality }\end{array}$ & 0 & 0 & Risk Ratio (M-H, Fixed, 95\% CI) & $0.0[0.0,0.0]$ \\
\hline $\begin{array}{l}\text { 1.2 Countries with high infant } \\
\text { mortality }\end{array}$ & 1 & 76176 & Risk Ratio (M-H, Fixed, 95\% CI) & $1.01[0.95,1.07]$ \\
\hline $\begin{array}{l}2 \text { Maternal mortality (infant } \\
\text { mortality level) }\end{array}$ & 4 & & Risk Ratio (Random, 95\% CI) & $0.88[0.65,1.20]$ \\
\hline $\begin{array}{l}\text { 2.1 Countries with low infant } \\
\text { mortality }\end{array}$ & 1 & & Risk Ratio (Random, 95\% CI) & $0.33[0.01,9.44]$ \\
\hline $\begin{array}{l}2.2 \text { Countries with high infant } \\
\text { mortality }\end{array}$ & 3 & & Risk Ratio (Random, 95\% CI) & $0.89[0.64,1.23]$ \\
\hline $\begin{array}{l}3 \text { Maternal mortality (maternal } \\
\text { mortality level) }\end{array}$ & 4 & 161240 & Risk Ratio (M-H, Fixed, 95\% CI) & $0.91[0.76,1.08]$ \\
\hline $\begin{array}{l}\text { 3.1 Countries with low } \\
\text { maternal mortality }\end{array}$ & 1 & 550 & Risk Ratio (M-H, Fixed, 95\% CI) & $0.33[0.01,8.15]$ \\
\hline $\begin{array}{l}\text { 3.2 Countries with high } \\
\text { maternal mortality }\end{array}$ & 3 & 160690 & Risk Ratio (M-H, Fixed, 95\% CI) & $0.91[0.76,1.08]$ \\
\hline $\begin{array}{l}4 \text { Perinatal mortality (maternal } \\
\text { mortality level) }\end{array}$ & 1 & 73743 & Risk Ratio (M-H, Fixed, 95\% CI) & $0.95[0.88,1.03]$ \\
\hline $\begin{array}{l}\text { 4.1 Countries with low } \\
\text { maternal mortality }\end{array}$ & 0 & 0 & Risk Ratio (M-H, Fixed, 95\% CI) & $0.0[0.0,0.0]$ \\
\hline $\begin{array}{l}\text { 4.2 Countries with high } \\
\text { maternal mortality }\end{array}$ & 1 & 73743 & Risk Ratio (M-H, Fixed, 95\% CI) & $0.95[0.88,1.03]$ \\
\hline
\end{tabular}

Vitamin A supplementation during pregnancy for maternal and newborn outcomes (Review) 
5 Maternal mortality (prevalence 4

of vitamin A deficiency)

5.1 Low prevalence of vitamin A deficiency

5.2 High prevalence of vitamin A deficiency

6 Perinatal mortality (prevalence of vitamin A deficiency)

6.1 Low prevalence of vitamin A deficiency

6.2 High prevalence of vitamin A deficiency

7 Maternal mortality (prevalence of HIV in the general population)

7.1 Countries with low HIV prevalence

7.2 Countries with high HIV prevalence

8 Perinatal mortality (prevalence of HIV in the general population)

8.1 Countries with low HIV prevalence

8.2 Countries with high HIV prevalence

9 Maternal mortality (dose)

9.1 Daily 10,000 IU

9.2 Others

10 Perinatal mortality (dose)

10.1 Daily 10,000 IU

10.2 Others

11 Maternal mortality (regimen)

11.1 Daily

11.2 Weekly

11.3 Other regimen

12 Perinatal mortality (regimen)

12.1 Daily

12.2 Weekly

12.3 Other regimen

13 Maternal mortality (duration of intervention)

13.1 One month or less 13.2 More than one month

14 Perinatal mortality (duration of intervention)

15 Maternal mortality (trimester of pregnancy)

15.1 Pre-pregnancy

15.2 First trimester

15.3 Second trimester

15.4 Third trimester
161240

Risk Ratio (M-H, Random, 95\% CI)

550 Risk Ratio (M-H, Random, 95\% CI)

$0.33[0.01,8.15]$

$0.88[0.63,1.23]$

$1.01[0.95,1.07]$

$0.0[0.0,0.0]$

$1.01[0.95,1.07]$

$0.87[0.64,1.20]$

$0.87[0.64,1.20]$

$0.0[0.0,0.0]$

$1.01[0.95,1.07]$

$1.01[0.95,1.07]$

$0.0[0.0,0.0]$

$0.88[0.63,1.23]$

$0.0[0.0,0.0]$

$0.88[0.63,1.23]$

$1.01[0.95,1.07]$

$0.0[0.0,0.0]$

$1.01[0.95,1.07]$

$0.87[0.64,1.20]$

0.33 [0.01, 8.15]

$0.88[0.63,1.23]$

$0.0[0.0,0.0]$

$1.01[0.95,1.07]$

$0.0[0.0,0.0]$

$1.01[0.95,1.07]$

$0.0[0.0,0.0]$

$1.16[0.82,1.64]$

0.33 [0.01, 8.15]

$1.18[0.83,1.68]$

$0.0[0.0,0.0]$

$0.87[0.64,1.20]$

$0.77[0.50,1.17]$

$1.18[0.83,1.68]$

$0.0[0.0,0.0]$

0.33 [0.01, 8.15] 


\begin{tabular}{|c|c|c|c|c|}
\hline 15.5 Mixed & 0 & 0 & Risk Ratio (M-H, Random, 95\% CI) & $0.0[0.0,0.0]$ \\
\hline $\begin{array}{l}16 \text { Perinatal mortality (trimester } \\
\text { of pregnancy) }\end{array}$ & 1 & 76176 & Risk Ratio (M-H, Fixed, 95\% CI) & $1.01[0.95,1.07]$ \\
\hline 16.1 Pre-pregnancy & 1 & 76176 & Risk Ratio (M-H, Fixed, 95\% CI) & $1.01[0.95,1.07]$ \\
\hline 16.2 First trimester & 0 & 0 & Risk Ratio (M-H, Fixed, 95\% CI) & $0.0[0.0,0.0]$ \\
\hline 16.3 Second trimester & 0 & 0 & Risk Ratio (M-H, Fixed, 95\% CI) & $0.0[0.0,0.0]$ \\
\hline 16.4 Third trimester & 0 & 0 & Risk Ratio (M-H, Fixed, 95\% CI) & $0.0[0.0,0.0]$ \\
\hline 16.5 Mixed & 0 & 0 & Risk Ratio (M-H, Fixed, 95\% CI) & $0.0[0.0,0.0]$ \\
\hline $\begin{array}{l}17 \text { Maternal mortality } \\
\text { (randomisation) }\end{array}$ & 3 & 160690 & Risk Ratio (M-H, Random, 95\% CI) & $0.88[0.63,1.23]$ \\
\hline 17.1 Cluster-randomised & 3 & 160690 & Risk Ratio (M-H, Random, 95\% CI) & $0.88[0.63,1.23]$ \\
\hline 17.2 Individual-randomised & 0 & 0 & Risk Ratio (M-H, Random, 95\% CI) & $0.0[0.0,0.0]$ \\
\hline $\begin{array}{l}18 \text { Perinatal mortality } \\
\text { (randomisation) }\end{array}$ & 1 & 76176 & Risk Ratio (M-H, Fixed, 95\% CI) & $1.01[0.95,1.07]$ \\
\hline 18.1 Cluster-randomised & 1 & 76176 & Risk Ratio (M-H, Fixed, 95\% CI) & $1.01[0.95,1.07]$ \\
\hline 18.2 Individual-randomised & 0 & 0 & Risk Ratio (M-H, Fixed, 95\% CI) & $0.0[0.0,0.0]$ \\
\hline
\end{tabular}

Comparison 5. Vitamin A alone versus micronutrient supplement without vitamin A (subgroups)

\begin{tabular}{|c|c|c|c|c|}
\hline Outcome or subgroup title & $\begin{array}{l}\text { No. of } \\
\text { studies }\end{array}$ & $\begin{array}{c}\text { No. of } \\
\text { participants }\end{array}$ & Statistical method & Effect size \\
\hline $\begin{array}{l}1 \text { Maternal mortality (infant } \\
\text { mortality level) }\end{array}$ & 0 & 0 & Risk Ratio (M-H, Fixed, 95\% CI) & $0.0[0.0,0.0]$ \\
\hline $\begin{array}{l}\text { 1.1 Countries with low infant } \\
\text { mortality }\end{array}$ & 0 & 0 & Risk Ratio (M-H, Fixed, 95\% CI) & $0.0[0.0,0.0]$ \\
\hline $\begin{array}{l}\text { 1.2 Countries with high infant } \\
\text { mortality }\end{array}$ & 0 & 0 & Risk Ratio (M-H, Fixed, 95\% CI) & $0.0[0.0,0.0]$ \\
\hline $\begin{array}{l}2 \text { Perinatal mortality (infant } \\
\text { mortality level) }\end{array}$ & 0 & 0 & Risk Ratio (M-H, Fixed, 95\% CI) & $0.0[0.0,0.0]$ \\
\hline $\begin{array}{l}\text { 2.1 Countries with low infant } \\
\text { mortality }\end{array}$ & 0 & 0 & Risk Ratio (M-H, Fixed, 95\% CI) & $0.0[0.0,0.0]$ \\
\hline $\begin{array}{l}2.2 \text { Countries with high infant } \\
\text { mortality }\end{array}$ & 0 & 0 & Risk Ratio (M-H, Fixed, 95\% CI) & $0.0[0.0,0.0]$ \\
\hline $\begin{array}{l}3 \text { Maternal mortality (maternal } \\
\text { mortality level) }\end{array}$ & 0 & 0 & Risk Ratio (M-H, Fixed, 95\% CI) & $0.0[0.0,0.0]$ \\
\hline $\begin{array}{l}\text { 3.1 Countries with low } \\
\text { maternal mortality }\end{array}$ & 0 & 0 & Risk Ratio (M-H, Fixed, 95\% CI) & $0.0[0.0,0.0]$ \\
\hline $\begin{array}{l}\text { 3.2 Countries with high } \\
\text { maternal mortality }\end{array}$ & 0 & 0 & Risk Ratio (M-H, Fixed, 95\% CI) & $0.0[0.0,0.0]$ \\
\hline $\begin{array}{l}4 \text { Perinatal mortality (maternal } \\
\text { mortality level) }\end{array}$ & 0 & 0 & Risk Ratio (M-H, Fixed, 95\% CI) & $0.0[0.0,0.0]$ \\
\hline $\begin{array}{l}\text { 4.1 Countries with low } \\
\text { maternal mortality }\end{array}$ & 0 & 0 & Risk Ratio (M-H, Fixed, 95\% CI) & $0.0[0.0,0.0]$ \\
\hline $\begin{array}{l}\text { 4.2 Countries with high } \\
\text { maternal mortality }\end{array}$ & 0 & 0 & Risk Ratio (M-H, Fixed, 95\% CI) & $0.0[0.0,0.0]$ \\
\hline $\begin{array}{l}5 \text { Maternal mortality (prevalence } \\
\text { of vitamin A deficiency) }\end{array}$ & 0 & 0 & Risk Ratio (M-H, Fixed, 95\% CI) & $0.0[0.0,0.0]$ \\
\hline
\end{tabular}

Vitamin A supplementation during pregnancy for maternal and newborn outcomes (Review) 
5.1 Low prevalence of vitamin A deficiency

5.2 High prevalence of vitamin A deficiency

6 Perinatal mortality (prevalence of vitamin A deficiency)

6.1 Low prevalence of vitamin A deficiency

6.2 High prevalence of vitamin A deficiency

7 Maternal mortality (prevalence of HIV in the general population)

7.1 Countries with low HIV prevalence

7.2 Countries with high HIV prevalence

8 Perinatal mortality (prevalence of $\mathrm{HIV}$ in the general population) 8.1 Countries with low HIV prevalence

8.2 Countries with high HIV prevalence

9 Maternal mortality (dose)

9.1 Daily 10,000 IU

9.2 Others

10 Perinatal mortality (dose)

10.1 Daily 10,000 IU

10.2 Others

11 Maternal mortality (regimen)

11.1 Daily

11.2 Weekly

11.3 Other regimen

12 Perinatal mortality (regimen)

12.1 Daily

12.2 Weekly

12.3 Other regimen

13 Maternal mortality (duration of intervention)

14 Perinatal mortality (duration of intervention)

15 Maternal mortality (trimester 0 of pregnancy)

15.1 Pre-pregnancy

15.2 First trimester

15.3 Second trimester

15.4 Third trimester

15.5 Mixed

16 Perinatal mortality (trimester of pregnancy)

16.1 Pre-pregnancy
Risk Ratio (M-H, Fixed, 95\% CI)

Risk Ratio (M-H, Fixed, 95\% CI)

Risk Ratio (M-H, Fixed, 95\% CI)

Risk Ratio (M-H, Fixed, 95\% CI)

Risk Ratio (M-H, Fixed, 95\% CI)

Risk Ratio (M-H, Fixed, 95\% CI)

Risk Ratio (M-H, Fixed, 95\% CI)

Risk Ratio (M-H, Fixed, 95\% CI)

Risk Ratio (M-H, Fixed, 95\% CI)

Risk Ratio (M-H, Fixed, 95\% CI)

Risk Ratio (M-H, Fixed, 95\% CI)

Risk Ratio (M-H, Fixed, 95\% CI)

Risk Ratio (M-H, Fixed, 95\% CI)

Risk Ratio (M-H, Fixed, 95\% CI)

Risk Ratio (M-H, Fixed, 95\% CI)

Risk Ratio (M-H, Fixed, 95\% CI)

Risk Ratio (M-H, Fixed, 95\% CI)

Risk Ratio (M-H, Fixed, 95\% CI)

Risk Ratio (M-H, Fixed, 95\% CI)

Risk Ratio (M-H, Fixed, 95\% CI)

Risk Ratio (M-H, Fixed, 95\% CI)

Risk Ratio (M-H, Fixed, 95\% CI)

Risk Ratio (M-H, Fixed, 95\% CI)

Risk Ratio (M-H, Fixed, 95\% CI)

Risk Ratio (M-H, Fixed, 95\% CI)

Risk Ratio (M-H, Fixed, 95\% CI)

Risk Ratio (M-H, Fixed, 95\% CI)

Risk Ratio (M-H, Fixed, 95\% CI)

Risk Ratio (M-H, Fixed, 95\% CI)

Risk Ratio (M-H, Fixed, 95\% CI)

Risk Ratio (M-H, Fixed, 95\% CI)

Risk Ratio (M-H, Fixed, 95\% CI)

Risk Ratio (M-H, Fixed, 95\% CI)

Risk Ratio (M-H, Fixed, 95\% CI)
$0.0[0.0,0.0]$

$0.0[0.0,0.0]$

$0.0[0.0,0.0]$

$0.0[0.0,0.0]$

$0.0[0.0,0.0]$

$0.0[0.0,0.0]$

$0.0[0.0,0.0]$

$0.0[0.0,0.0]$

$0.0[0.0,0.0]$

$0.0[0.0,0.0]$

$0.0[0.0,0.0]$

$0.0[0.0,0.0]$

$0.0[0.0,0.0]$

$0.0[0.0,0.0]$

$0.0[0.0,0.0]$

$0.0[0.0,0.0]$

$0.0[0.0,0.0]$

$0.0[0.0,0.0]$

$0.0[0.0,0.0]$

$0.0[0.0,0.0]$

$0.0[0.0,0.0]$

$0.0[0.0,0.0]$

$0.0[0.0,0.0]$

$0.0[0.0,0.0]$

$0.0[0.0,0.0]$

$0.0[0.0,0.0]$

$0.0[0.0,0.0]$

$0.0[0.0,0.0]$

$0.0[0.0,0.0]$

$0.0[0.0,0.0]$

$0.0[0.0,0.0]$

$0.0[0.0,0.0]$

$0.0[0.0,0.0]$

$0.0[0.0,0.0]$

$0.0[0.0,0.0]$ 
16.2 First trimester

16.3 Second trimester

16.4 Third trimester

16.5 Mixed

17 Maternal mortality

(randomisation)

17.1 Cluster-randomised

17.2 Individual-randomised

18 Perinatal mortality

(randomisation)

18.1 Cluster-randomised

18.2 Individual-randomised
Risk Ratio (M-H, Fixed, 95\% CI)

$0.0[0.0,0.0]$

$0.0[0.0,0.0]$

$0.0[0.0,0.0]$

$0.0[0.0,0.0]$

$0.0[0.0,0.0]$

Risk Ratio (M-H, Fixed, 95\% Cl)

$0.0[0.0,0.0]$

$0.0[0.0,0.0]$

$0.0[0.0,0.0]$

Risk Ratio (M-H, Fixed, 95\% CI)

$0.0[0.0,0.0]$

$0.0[0.0,0.0]$

Comparison 6. Vitamin A with other micronutrients versus micronutrient supplements without vitamin A (subgroups)

\begin{tabular}{|c|c|c|c|c|}
\hline Outcome or subgroup title & $\begin{array}{l}\text { No. of } \\
\text { studies }\end{array}$ & $\begin{array}{c}\text { No. of } \\
\text { participants }\end{array}$ & Statistical method & Effect size \\
\hline $\begin{array}{l}1 \text { Maternal mortality (infant } \\
\text { mortality level) }\end{array}$ & 0 & 0 & Risk Ratio (M-H, Fixed, 95\% CI) & $0.0[0.0,0.0]$ \\
\hline $\begin{array}{l}\text { 1.1 Countries with low infant } \\
\text { mortality }\end{array}$ & 0 & 0 & Risk Ratio (M-H, Fixed, 95\% CI) & $0.0[0.0,0.0]$ \\
\hline $\begin{array}{l}\text { 1.2 Countries with high infant } \\
\text { mortality }\end{array}$ & 0 & 0 & Risk Ratio (M-H, Fixed, 95\% CI) & $0.0[0.0,0.0]$ \\
\hline $\begin{array}{l}2 \text { Perinatal mortality (infant } \\
\text { mortality level) }\end{array}$ & 1 & 179 & Risk Ratio (M-H, Fixed, 95\% CI) & $0.51[0.10,2.69]$ \\
\hline $\begin{array}{l}\text { 2.1 Countries with low infant } \\
\text { mortality }\end{array}$ & 0 & 0 & Risk Ratio (M-H, Fixed, 95\% CI) & $0.0[0.0,0.0]$ \\
\hline $\begin{array}{l}\text { 2.2 Countries with high infant } \\
\text { mortality }\end{array}$ & 1 & 179 & Risk Ratio (M-H, Fixed, 95\% CI) & $0.51[0.10,2.69]$ \\
\hline $\begin{array}{l}3 \text { Maternal mortality (maternal } \\
\text { mortality level) }\end{array}$ & 0 & 0 & Risk Ratio (M-H, Fixed, 95\% CI) & $0.0[0.0,0.0]$ \\
\hline $\begin{array}{l}\text { 3.1 Countries with low } \\
\text { maternal mortality }\end{array}$ & 0 & 0 & Risk Ratio (M-H, Fixed, 95\% CI) & $0.0[0.0,0.0]$ \\
\hline $\begin{array}{l}\text { 3.2 Countries with high } \\
\text { maternal mortality }\end{array}$ & 0 & 0 & Risk Ratio (M-H, Fixed, 95\% CI) & $0.0[0.0,0.0]$ \\
\hline $\begin{array}{l}4 \text { Perinatal mortality (maternal } \\
\text { mortality level) }\end{array}$ & 1 & 179 & Risk Ratio (M-H, Fixed, 95\% CI) & $0.51[0.10,2.69]$ \\
\hline $\begin{array}{l}\text { 4.1 Countries with low } \\
\text { maternal mortality }\end{array}$ & 0 & 0 & Risk Ratio (M-H, Fixed, 95\% CI) & $0.0[0.0,0.0]$ \\
\hline $\begin{array}{l}\text { 4.2 Countries with high } \\
\text { maternal mortality }\end{array}$ & 1 & 179 & Risk Ratio (M-H, Fixed, 95\% CI) & $0.51[0.10,2.69]$ \\
\hline $\begin{array}{l}5 \text { Maternal mortality (prevalence } \\
\text { of vitamin A deficiency) }\end{array}$ & 1 & 179 & Risk Ratio (M-H, Fixed, 95\% CI) & $0.51[0.10,2.69]$ \\
\hline $\begin{array}{l}5.1 \text { Low prevalence of vitamin } \\
\text { A deficiency }\end{array}$ & 0 & 0 & Risk Ratio (M-H, Fixed, 95\% CI) & $0.0[0.0,0.0]$ \\
\hline
\end{tabular}

Vitamin A supplementation during pregnancy for maternal and newborn outcomes (Review) 
5.2 High prevalence of vitamin A deficiency of vitamin A deficiency)

6.1 Low prevalence of vitamin A deficiency

6.2 High prevalence of vitamin A deficiency

7 Maternal mortality (prevalence of HIV in the general population)

7.1 Countries with low HIV prevalence

7.2 Countries with high HIV prevalence

8 Perinatal mortality (prevalence of $\mathrm{HIV}$ in the general population)

8.1 Countries with low HIV prevalence

8.2 Countries with high HIV prevalence

9 Maternal mortality (dose)

9.1 Daily 10,000 IU

9.2 Others

10 Perinatal mortality (dose) 10.1 Daily 10,000 IU 10.2 Others

11 Maternal mortality (regimen)

11.1 Daily

11.2 Weekly

11.3 Other regimen

12 Perinatal mortality (regimen)

12.1 Daily

12.2 Weekly

12.3 Other regimen

13 Maternal mortality (duration of intervention)

14 Perinatal mortality (duration of intervention)

15 Maternal mortality (trimester of pregnancy)

15.1 Pre-pregnancy

15.2 First trimester

15.3 Second trimester

15.4 Third trimester

15.5 Mixed

16 Perinatal mortality (trimester

of pregnancy)

16.1 Pre-pregnancy

16.2 First trimester

16.3 Second trimester

16.4 Third trimester
6 Perinatal mortality (prevalence

Risk Ratio (M-H, Fixed, 95\% CI)

\section{$0.51[0.10,2.69]$}

$0.51[0.10,2.69]$

$0.51[0.10,2.69]$

$0.0[0.0,0.0]$

$0.0[0.0,0.0]$

$0.0[0.0,0.0]$

$0.0[0.0,0.0]$

$0.51[0.10,2.69]$

$0.51[0.10,2.69]$

$0.0[0.0,0.0]$

$0.0[0.0,0.0]$

$0.0[0.0,0.0]$

$0.0[0.0,0.0]$

$0.51[0.10,2.69]$

$0.0[0.0,0.0]$

$0.51[0.10,2.69]$

$0.0[0.0,0.0]$

$0.0[0.0,0.0]$

$0.0[0.0,0.0]$

$0.0[0.0,0.0]$

$0.51[0.10,2.69]$

$0.51[0.10,2.69]$

$0.0[0.0,0.0]$

$0.0[0.0,0.0]$

$0.0[0.0,0.0]$

$0.0[0.0,0.0]$

$0.0[0.0,0.0]$

Risk Ratio (M-H, Fixed, 95\% CI)

Risk Ratio (M-H, Fixed, 95\% CI)

Risk Ratio (M-H, Fixed, 95\% CI)

Risk Ratio (M-H, Fixed, 95\% CI)

Risk Ratio (M-H, Fixed, 95\% CI)

Risk Ratio (M-H, Fixed, 95\% CI)

$0.0[0.0,0.0]$

$0.0[0.0,0.0]$

$0.0[0.0,0.0]$

$0.0[0.0,0.0]$

$0.0[0.0,0.0]$

$0.51[0.10,2.69]$

Risk Ratio (M-H, Fixed, 95\% CI)

$0.0[0.0,0.0]$

$0.0[0.0,0.0]$

$0.0[0.0,0.0]$

$0.0[0.0,0.0]$ 
16.5 Mixed

17 Maternal mortality

(randomisation)

17.1 Cluster-randomised

17.2 Individual-randomised

18 Perinatal mortality

(randomisation)

18.1 Cluster-randomised

18.2 Individual-randomised
1

0

0

0

1
179

0

0

0
Risk Ratio (M-H, Fixed, 95\% CI)

Risk Ratio (M-H, Fixed, 95\% CI)

Risk Ratio (M-H, Fixed, 95\% CI)

Risk Ratio (M-H, Fixed, 95\% CI)

Risk Ratio (M-H, Fixed, 95\% CI)

Risk Ratio (M-H, Fixed, 95\% CI)

Risk Ratio (M-H, Fixed, 95\% CI)
$0.51[0.10,2.69]$

$0.0[0.0,0.0]$

$0.0[0.0,0.0]$

$0.0[0.0,0.0]$

$0.51[0.10,2.69]$

$0.0[0.0,0.0]$ $0.51[0.10,2.69]$

\section{Analysis I.I. Comparison I Vitamin A alone versus placebo or no treatment, Outcome I Maternal mortality.}

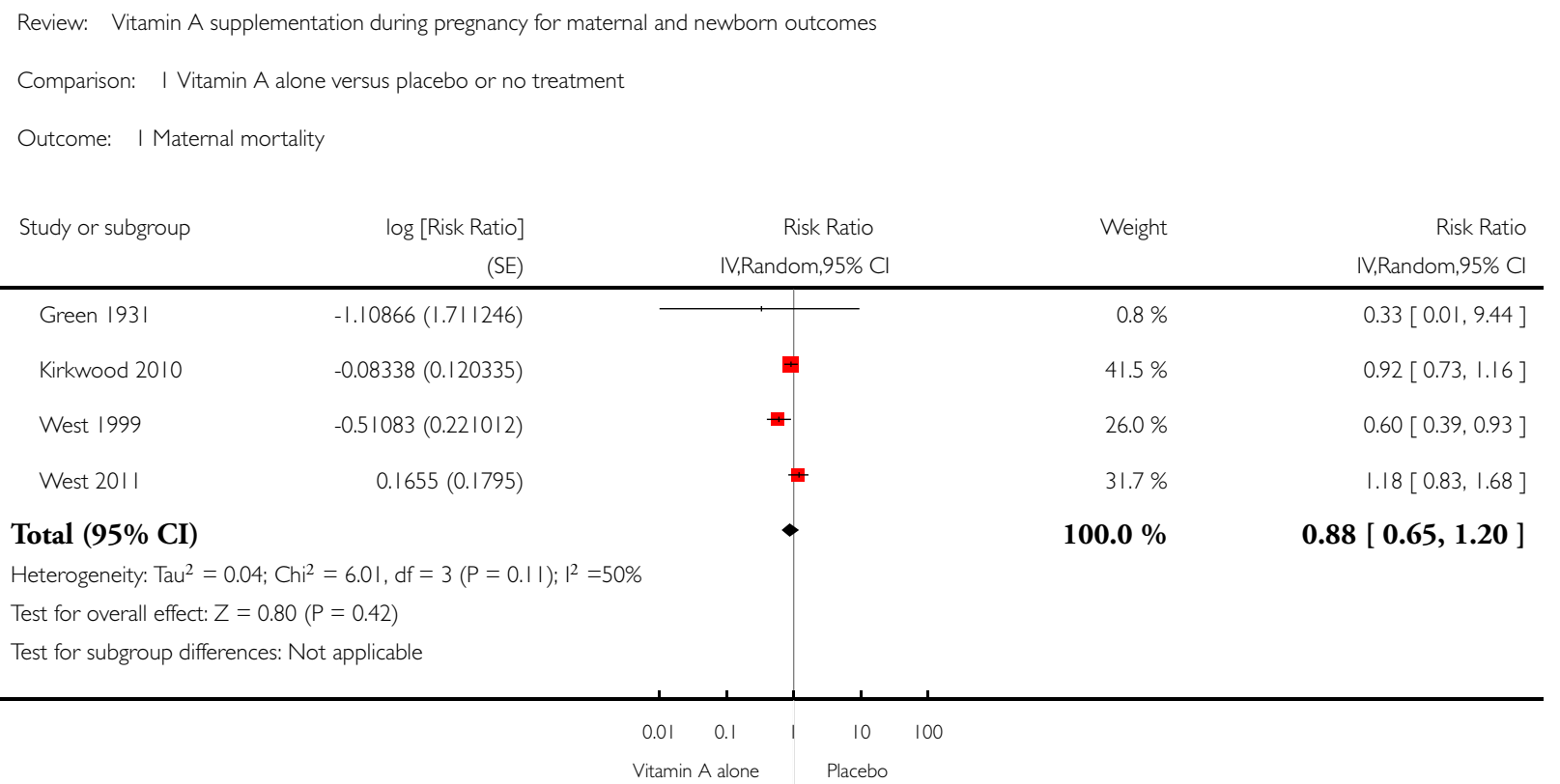


Analysis I.2. Comparison I Vitamin A alone versus placebo or no treatment, Outcome 2 Perinatal mortality.

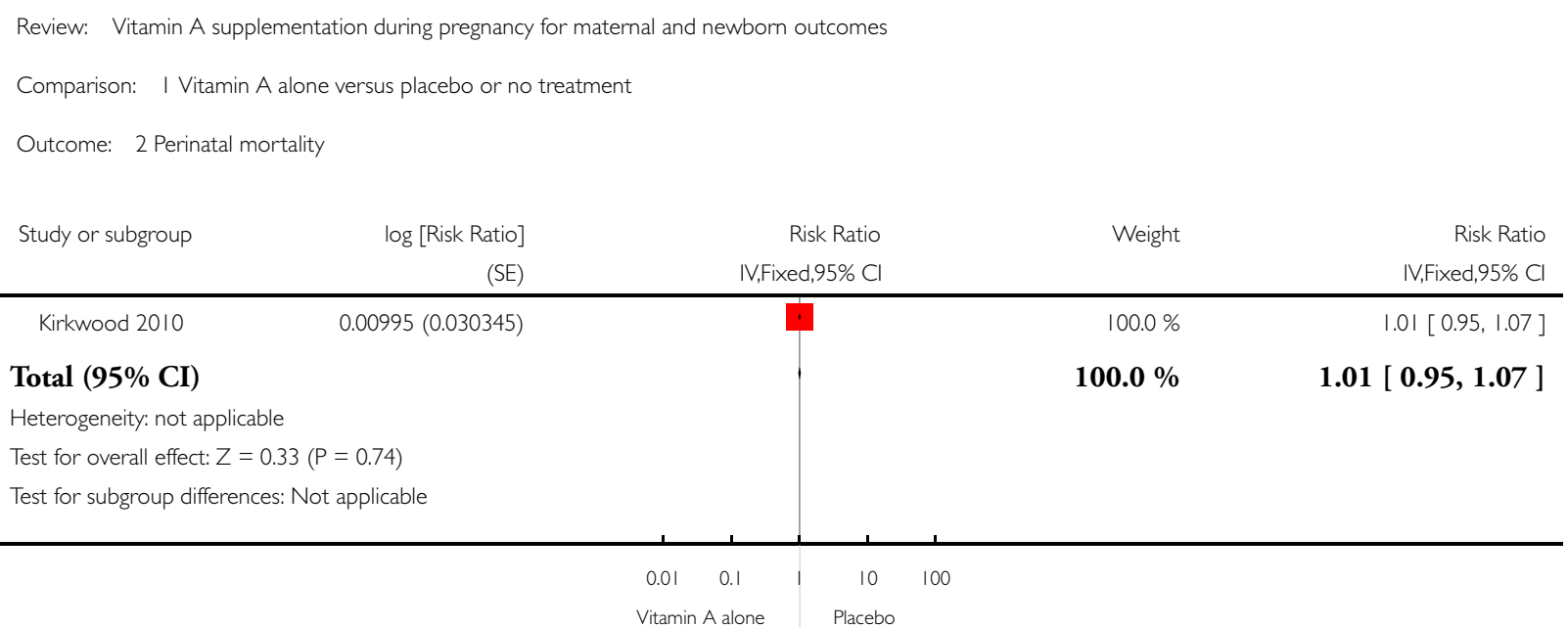

Analysis I.3. Comparison I Vitamin A alone versus placebo or no treatment, Outcome 3 Neonatal mortality.

Review: Vitamin A supplementation during pregnancy for maternal and newborn outcomes

Comparison: I Vitamin A alone versus placebo or no treatment

Outcome: 3 Neonatal mortality

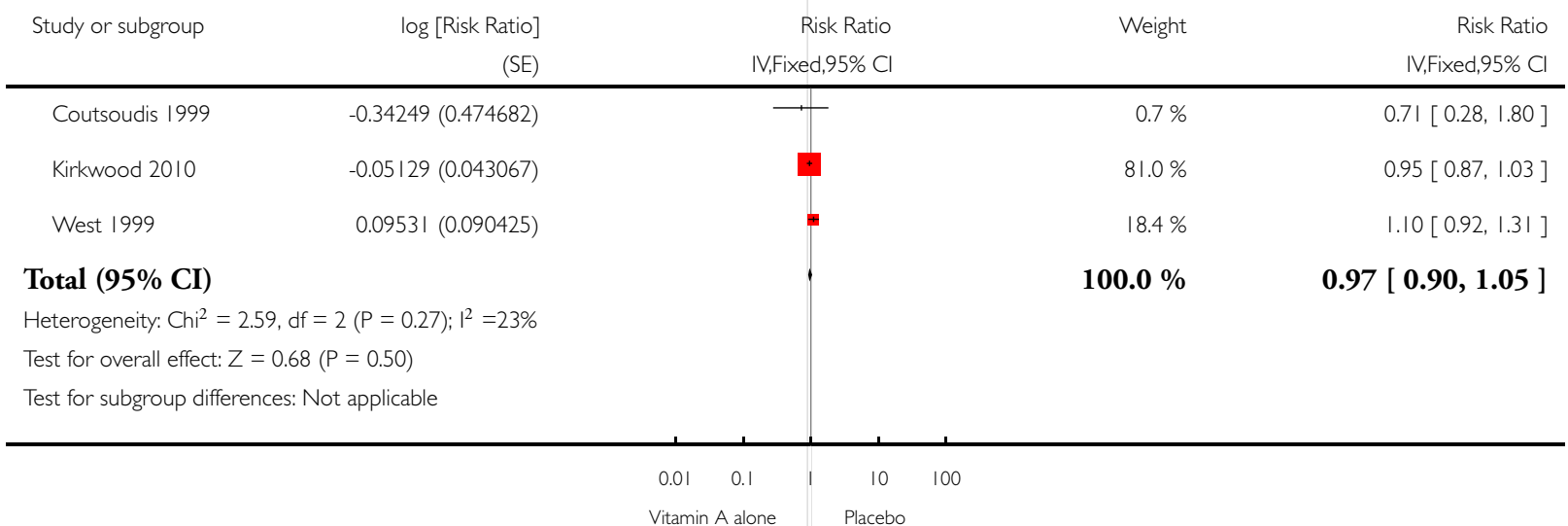




\section{Analysis I.4. Comparison I Vitamin A alone versus placebo or no treatment, Outcome 4 Stillbirth.}

Review: Vitamin A supplementation during pregnancy for maternal and newborn outcomes

Comparison: I Vitamin A alone versus placebo or no treatment

Outcome: 4 Stillbirth

\begin{tabular}{|c|c|c|c|c|c|}
\hline Study or subgroup & Vit A & $\begin{array}{r}\text { Placebo or } \\
\text { no } \\
\text { treatment }\end{array}$ & Risk Ratio & Weight & Risk Ratio \\
\hline & $\mathrm{n} / \mathrm{N}$ & $\mathrm{n} / \mathrm{N}$ & M-H,Fixed,95\% Cl & & M-H,Fixed,95\% Cl \\
\hline Kirkwood 2010 & $1249 / 39512$ & | | 75/39323 & & $55.7 \%$ & $1.06[0.98,1.14]$ \\
\hline West 2011 & |43|/29347 & $703 / 14668$ & 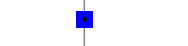 & $44.3 \%$ & $1.02[0.93,1.11]$ \\
\hline
\end{tabular}

Total $(95 \% \mathrm{CI})$

68859

53991

Total events: 2680 (Vit A), 1878 (Placebo or no treatment)

Heterogeneity: $\mathrm{Chi}^{2}=0.42, \mathrm{df}=\mathrm{I}(\mathrm{P}=0.52) ; \mathrm{I}^{2}=0.0 \%$

Test for overall effect: $Z=1.31(P=0.19)$

Test for subgroup differences: Not applicable

$\begin{array}{rrrrr}0.01 & 0.1 & 1 & 10 & 100 \\ \text { Vitamin } \mathrm{A} \text { alone } & \text { Placebo }\end{array}$

$100.0 \%$

$1.04[0.98,1.10]$

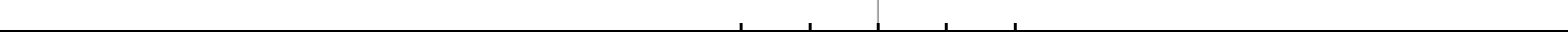

Vitamin A alone Placebo

Analysis I.5. Comparison I Vitamin A alone versus placebo or no treatment, Outcome 5 Maternal anaemia.

Review: Vitamin A supplementation during pregnancy for maternal and newborn outcomes

Comparison: I Vitamin A alone versus placebo or no treatment

Outcome: 5 Maternal anaemia

\begin{tabular}{|c|c|c|c|c|}
\hline Study or subgroup & log [Risk Ratio] & Risk Ratio & Weight & Risk Ratio \\
\hline & (SE) & IV,Random,95\% Cl & & IV,Random,95\% Cl \\
\hline Fawzi 1998 & $-0.17435(0.255778)$ & 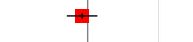 & $27.7 \%$ & $0.84[0.51,1.39]$ \\
\hline Suharno 1993 & $-0.96758(0.261069)$ & $\mp$ & $27.2 \%$ & $0.38[0.23,0.63]$ \\
\hline West 1999 & $-0.3|47|(0.090425)$ & + & $45.2 \%$ & $0.73[0.61,0.87]$ \\
\hline
\end{tabular}

Total (95\% CI)

$100.0 \%$

$0.64[0.43,0.94]$

Heterogeneity: $\operatorname{Tau}^{2}=0.08 ; \mathrm{Chi}^{2}=6.19, \mathrm{df}=2(\mathrm{P}=0.05) ; \mathrm{I}^{2}=68 \%$

Test for overall effect: $Z=2.24(P=0.025)$

Test for subgroup differences: Not applicable

$\begin{array}{lllll}0.01 & 0.1 & 1 & 10 & 100\end{array}$

Vitamin A alone Placebo

Vitamin A supplementation during pregnancy for maternal and newborn outcomes (Review)

Copyright @ 2015 The Cochrane Collaboration. Published by John Wiley \& Sons, Ltd. 


\section{Analysis I.6. Comparison I Vitamin A alone versus placebo or no treatment, Outcome 6 Maternal clinical}

infection.

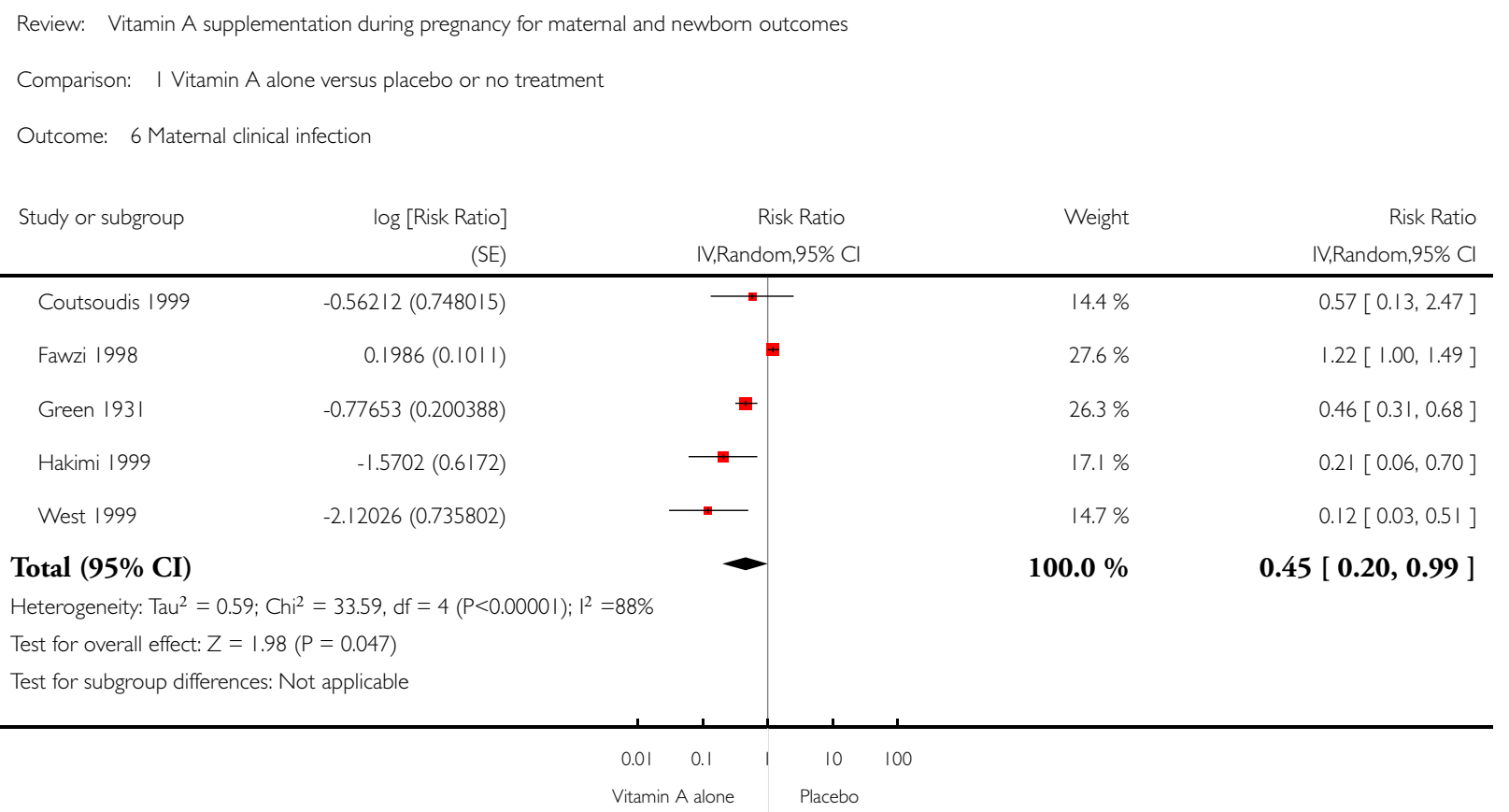


Analysis I.7. Comparison I Vitamin A alone versus placebo or no treatment, Outcome 7 Maternal night blindness.

Review: Vitamin A supplementation during pregnancy for maternal and newborn outcomes

Comparison: I Vitamin A alone versus placebo or no treatment

Outcome: 7 Maternal night blindness

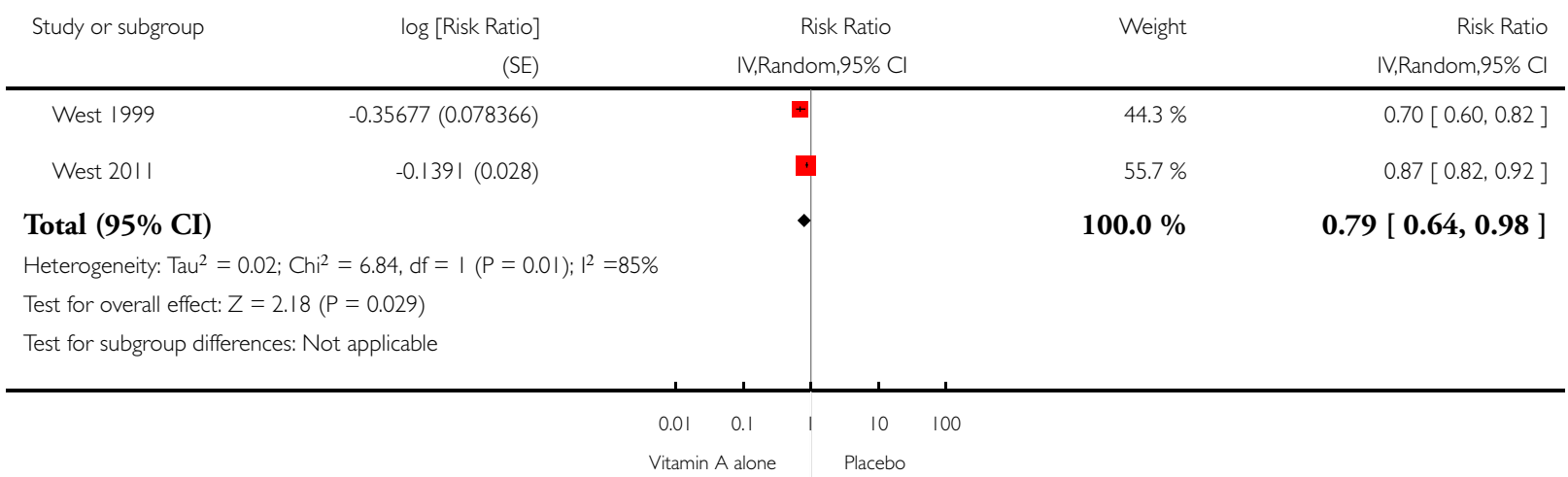


Analysis I.8. Comparison I Vitamin A alone versus placebo or no treatment, Outcome 8 Preterm birth.

Review: Vitamin A supplementation during pregnancy for maternal and newborn outcomes

Comparison: I Vitamin A alone versus placebo or no treatment

Outcome: 8 Preterm birth

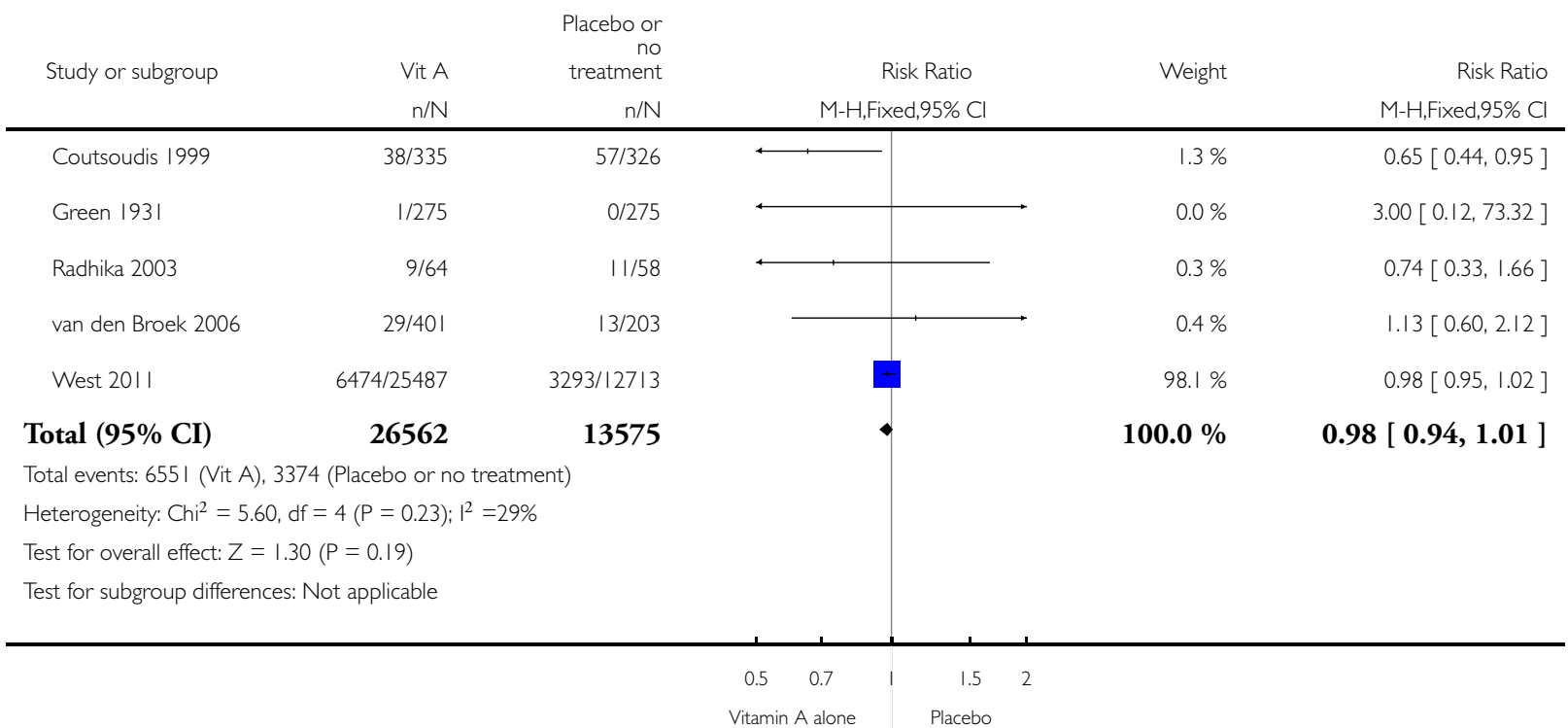


Analysis I.9. Comparison I Vitamin A alone versus placebo or no treatment, Outcome 9 Neonatal anaemia.

Review: Vitamin A supplementation during pregnancy for maternal and newborn outcomes

Comparison: I Vitamin A alone versus placebo or no treatment

Outcome: 9 Neonatal anaemia

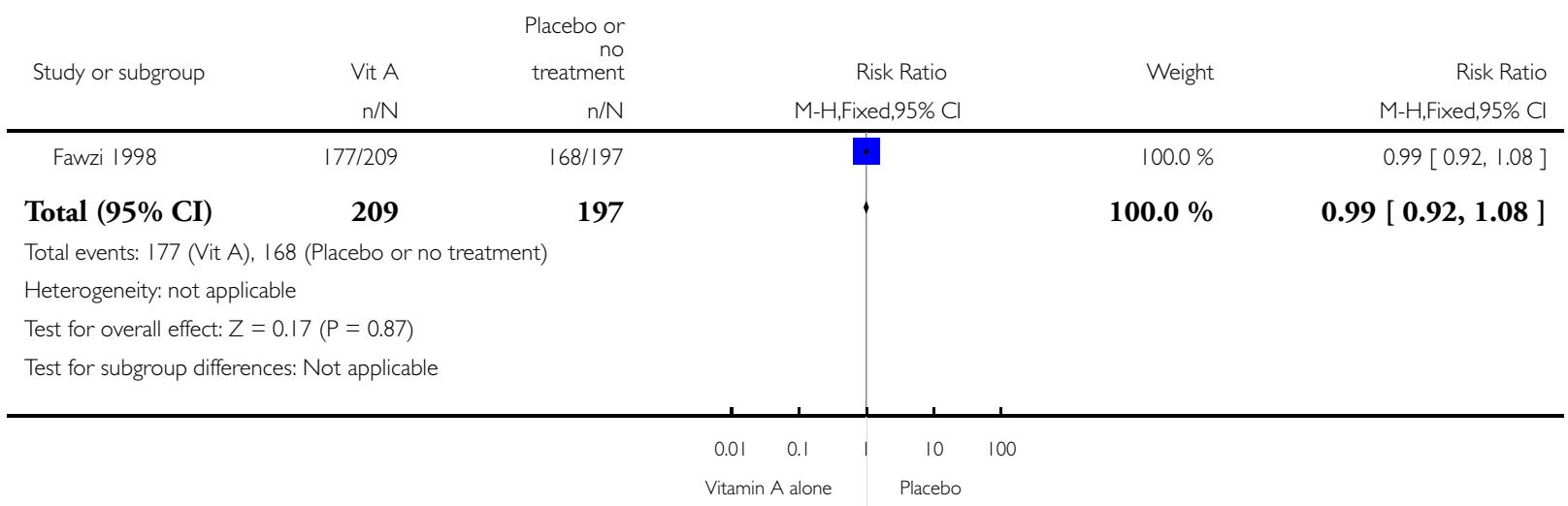


Analysis I.I2. Comparison I Vitamin A alone versus placebo or no treatment, Outcome I2 Low birthweight.

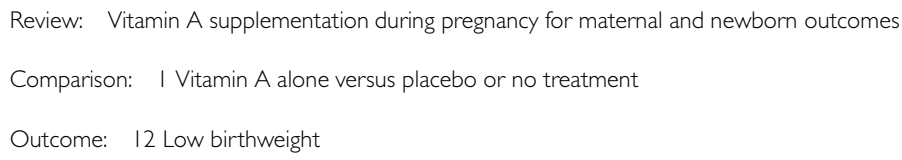

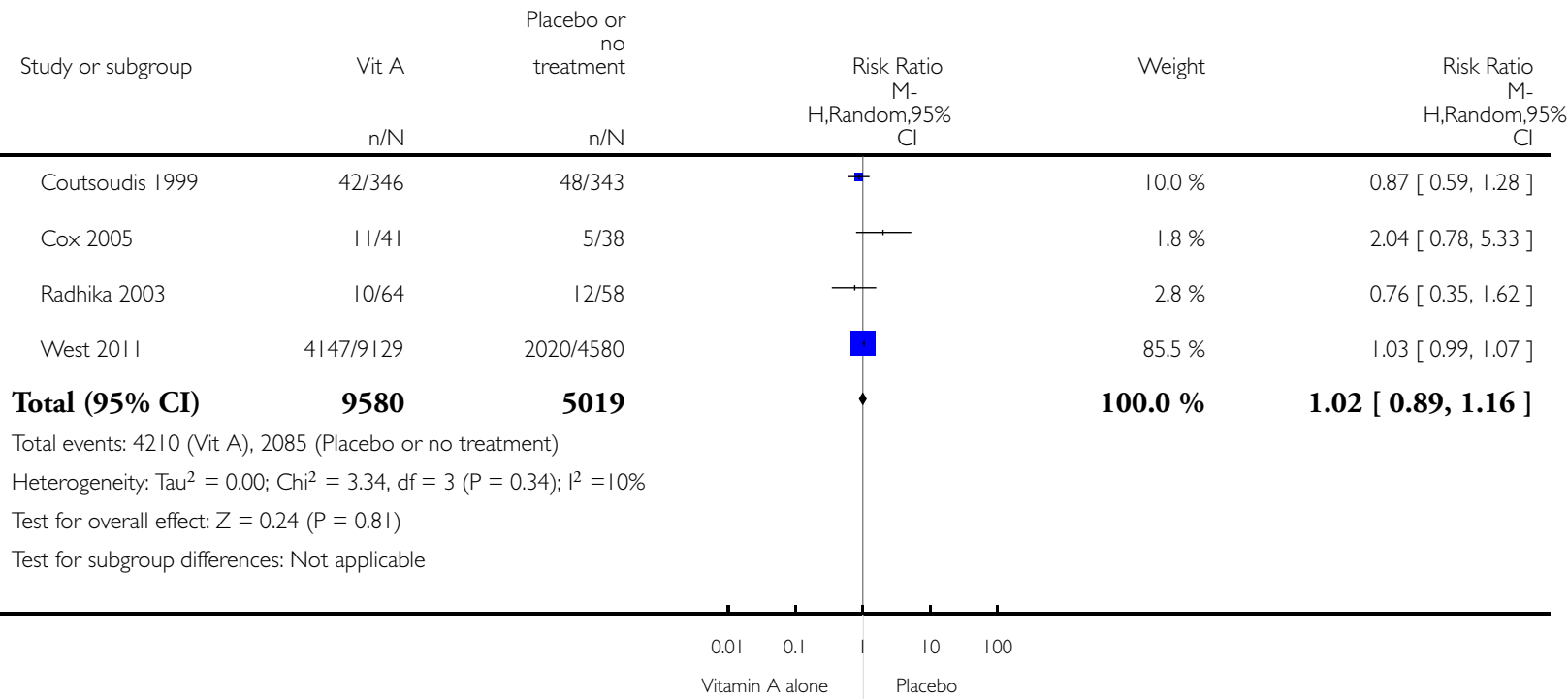




\section{Analysis 2.6. Comparison 2 Vitamin A alone versus micronutrient supplement without vitamin A, Outcome 6 Maternal clinical infection.}

Review: Vitamin A supplementation during pregnancy for maternal and newborn outcomes

Comparison: 2 Vitamin A alone versus micronutrient supplement without vitamin A

Outcome: 6 Maternal clinical infection

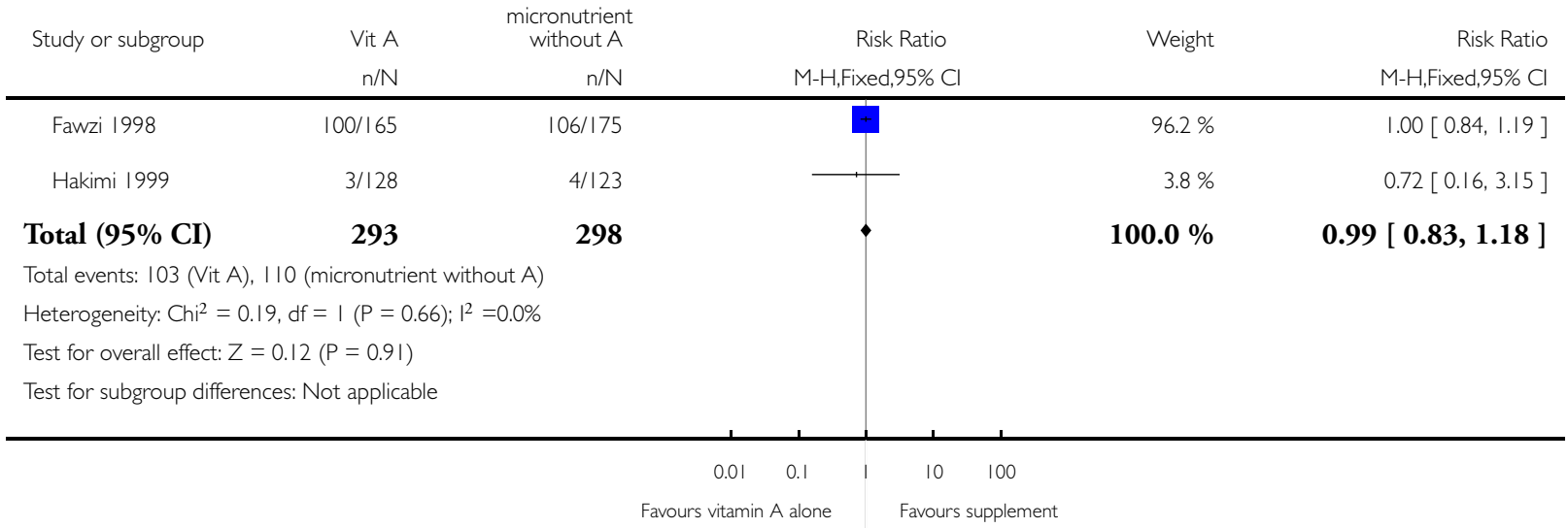

\section{Analysis 3.2. Comparison 3 Vitamin A with other micronutrients versus micronutrient supplements} without vitamin A, Outcome 2 Perinatal mortality.

Review: Vitamin A supplementation during pregnancy for maternal and newborn outcomes

Comparison: 3 Vitamin A with other micronutrients versus micronutrient supplements without vitamin $A$

Outcome: 2 Perinatal mortality

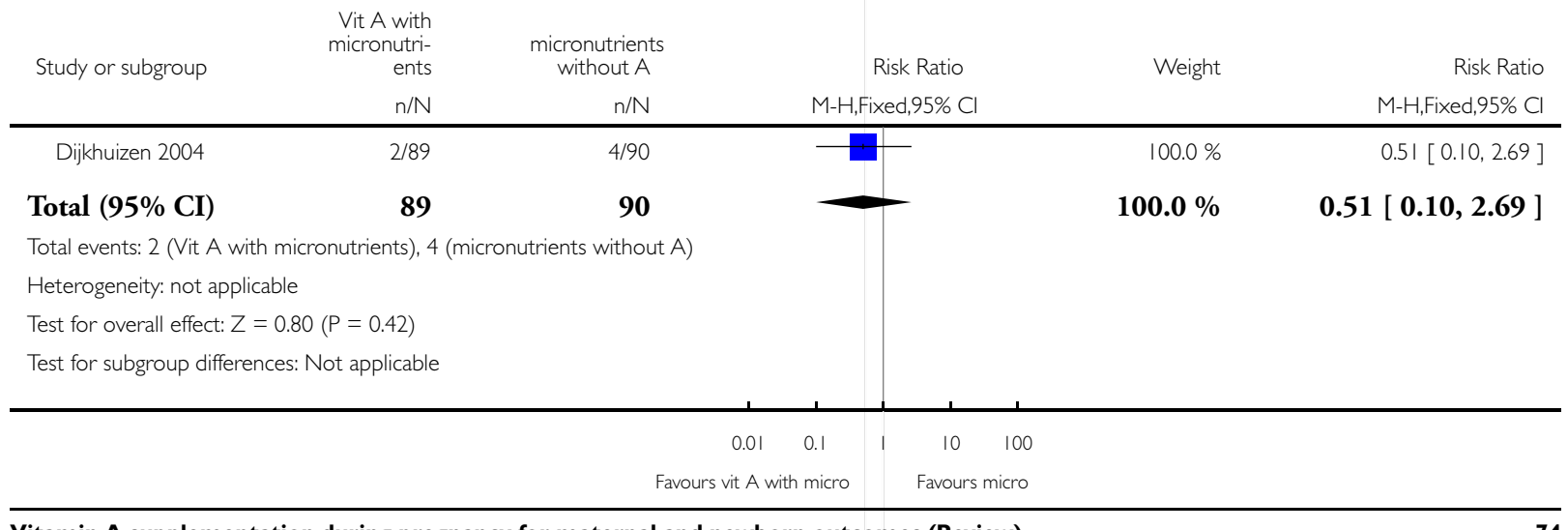

Vitamin A supplementation during pregnancy for maternal and newborn outcomes (Review)

Copyright @ 2015 The Cochrane Collaboration. Published by John Wiley \& Sons, Ltd. 


\section{Analysis 3.3. Comparison 3 Vitamin A with other micronutrients versus micronutrient supplements}

without vitamin A, Outcome 3 Neonatal mortality.

Review: Vitamin A supplementation during pregnancy for maternal and newborn outcomes

Comparison: 3 Vitamin A with other micronutrients versus micronutrient supplements without vitamin A

Outcome: 3 Neonatal mortality

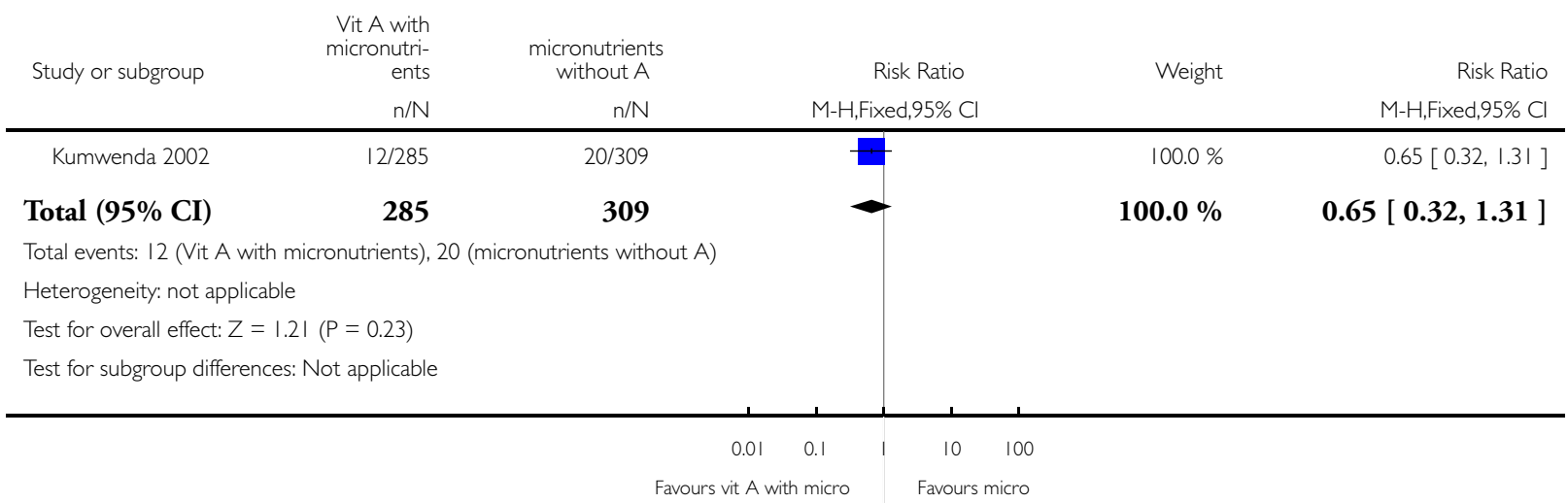




\section{Analysis 3.4. Comparison 3 Vitamin A with other micronutrients versus micronutrient supplements}

without vitamin A, Outcome 4 Stillbirth.

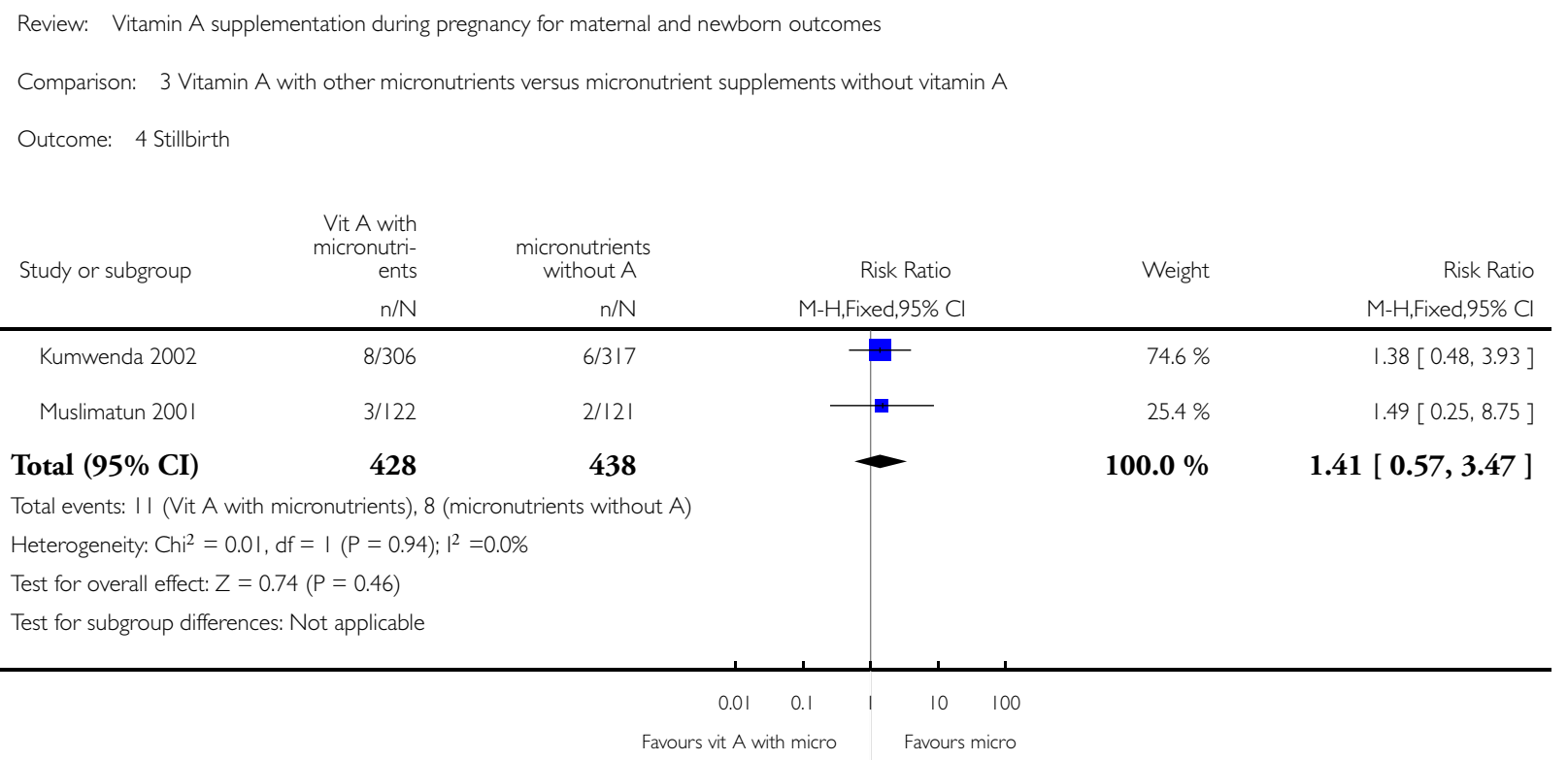


Analysis 3.5. Comparison 3 Vitamin A with other micronutrients versus micronutrient supplements without vitamin A, Outcome 5 Maternal anaemia.

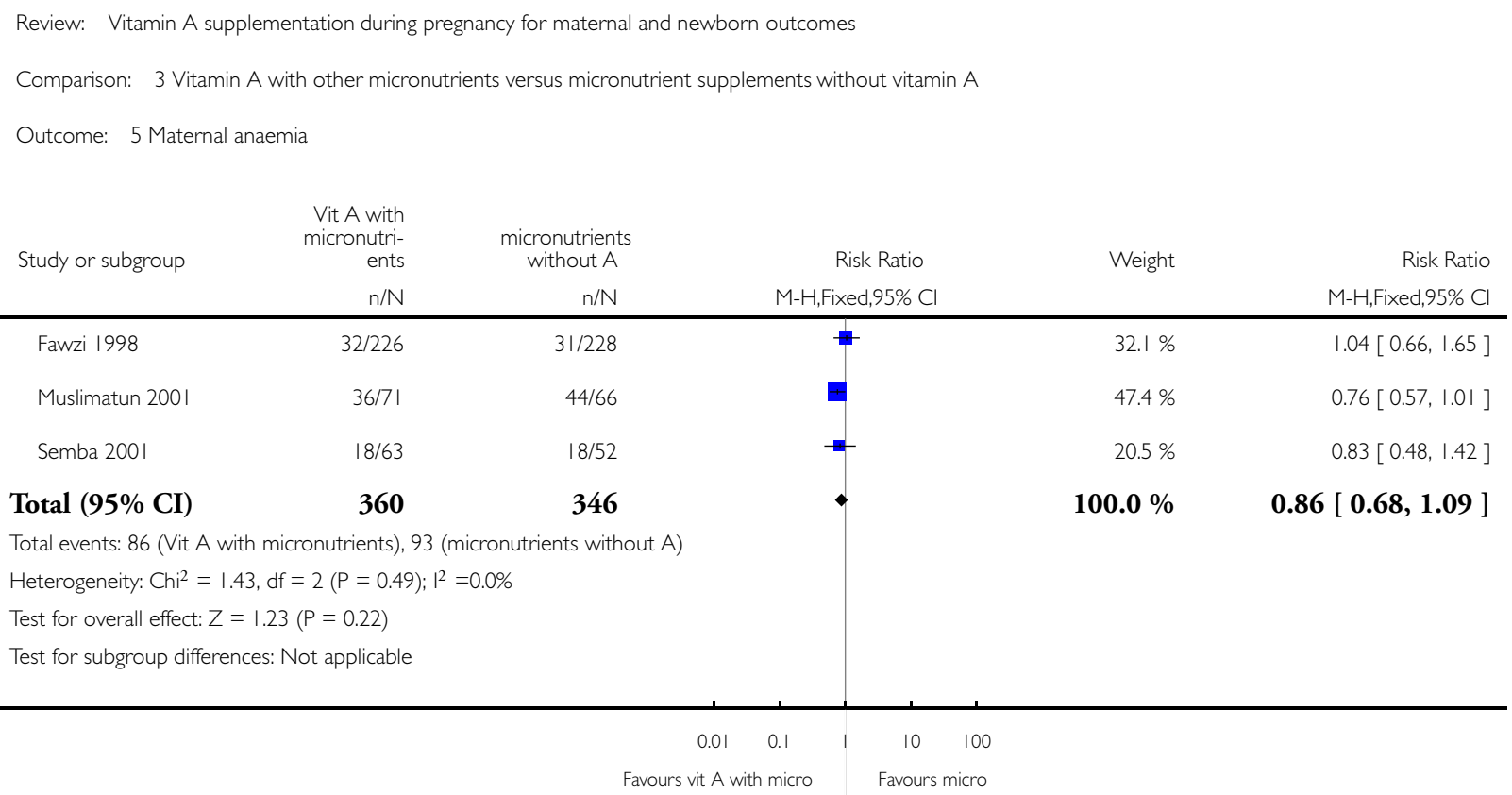


Analysis 3.6. Comparison 3 Vitamin A with other micronutrients versus micronutrient supplements without vitamin A, Outcome 6 Maternal clinical infection.

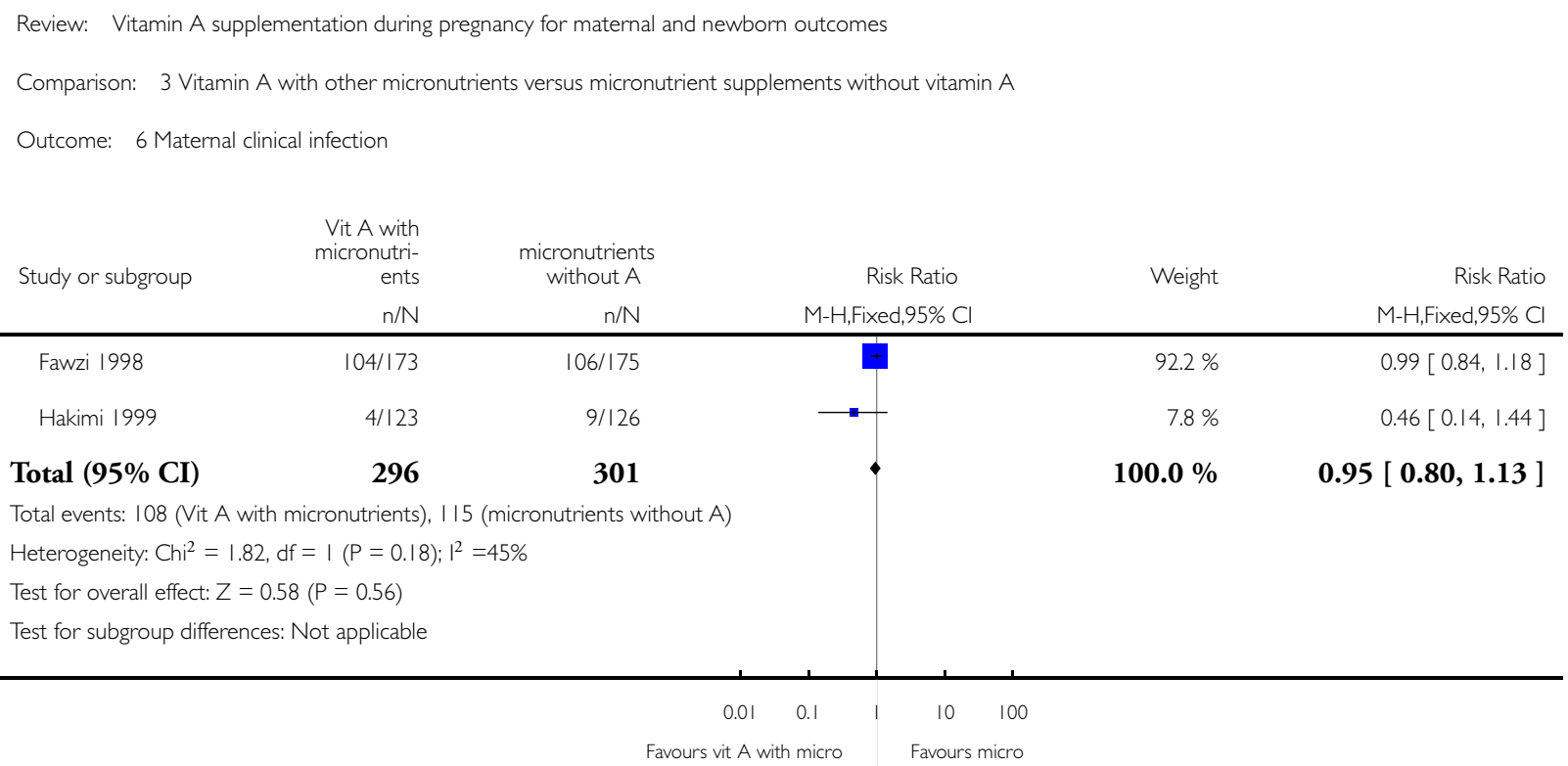

\section{Analysis 3.8. Comparison 3 Vitamin A with other micronutrients versus micronutrient supplements without vitamin A, Outcome 8 Preterm birth.}

Review: Vitamin A supplementation during pregnancy for maternal and newborn outcomes

Comparison: 3 Vitamin A with other micronutrients versus micronutrient supplements without vitamin A

Outcome: 8 Preterm birth

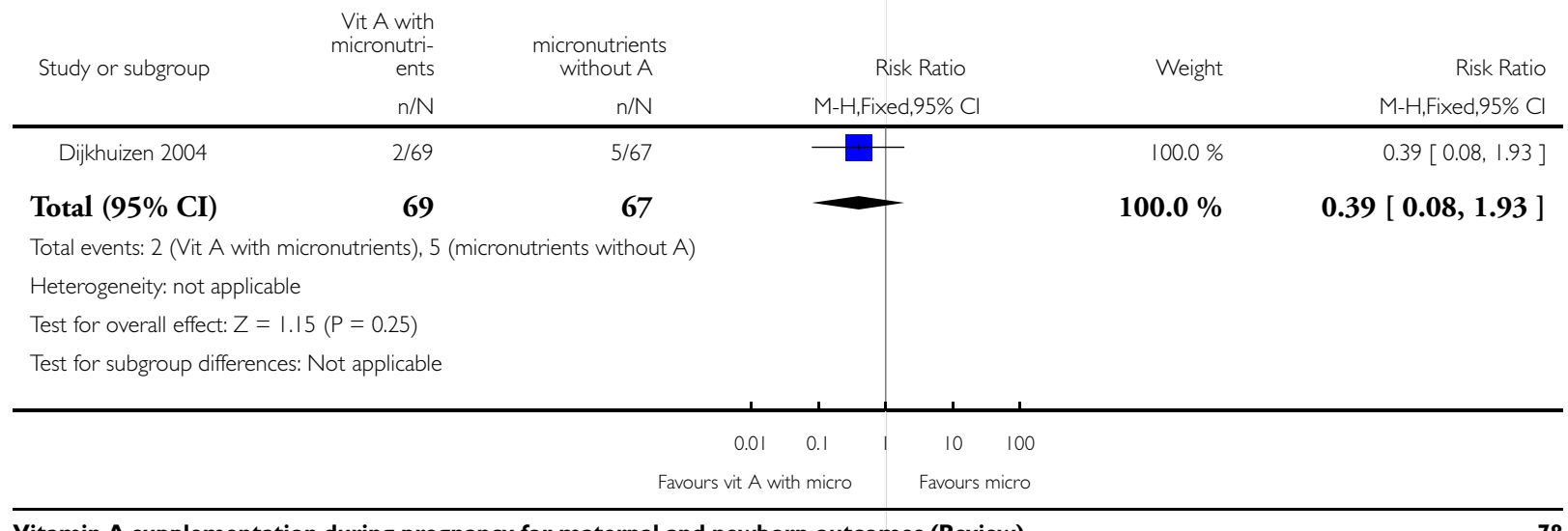

Vitamin A supplementation during pregnancy for maternal and newborn outcomes (Review)

Copyright (c) 2015 The Cochrane Collaboration. Published by John Wiley \& Sons, Ltd. 


\section{Analysis 3.9. Comparison 3 Vitamin A with other micronutrients versus micronutrient supplements}

without vitamin A, Outcome 9 Neonatal anaemia.

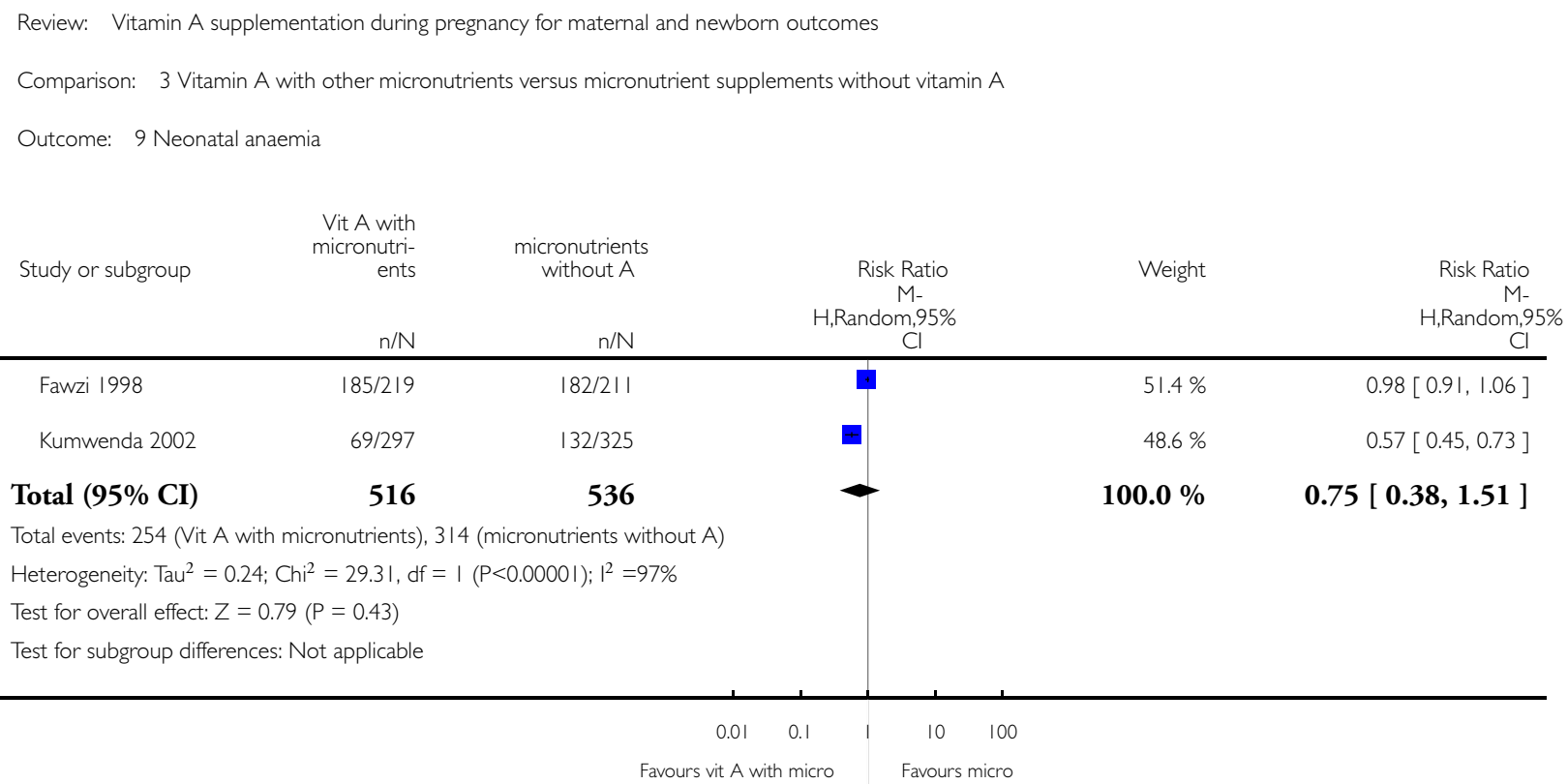


Analysis 3.I I. Comparison 3 Vitamin A with other micronutrients versus micronutrient supplements without vitamin A, Outcome I I Congenital malformations.

Review: Vitamin A supplementation during pregnancy for maternal and newborn outcomes

Comparison: 3 Vitamin A with other micronutrients versus micronutrient supplements without vitamin A

Outcome: II Congenital malformations

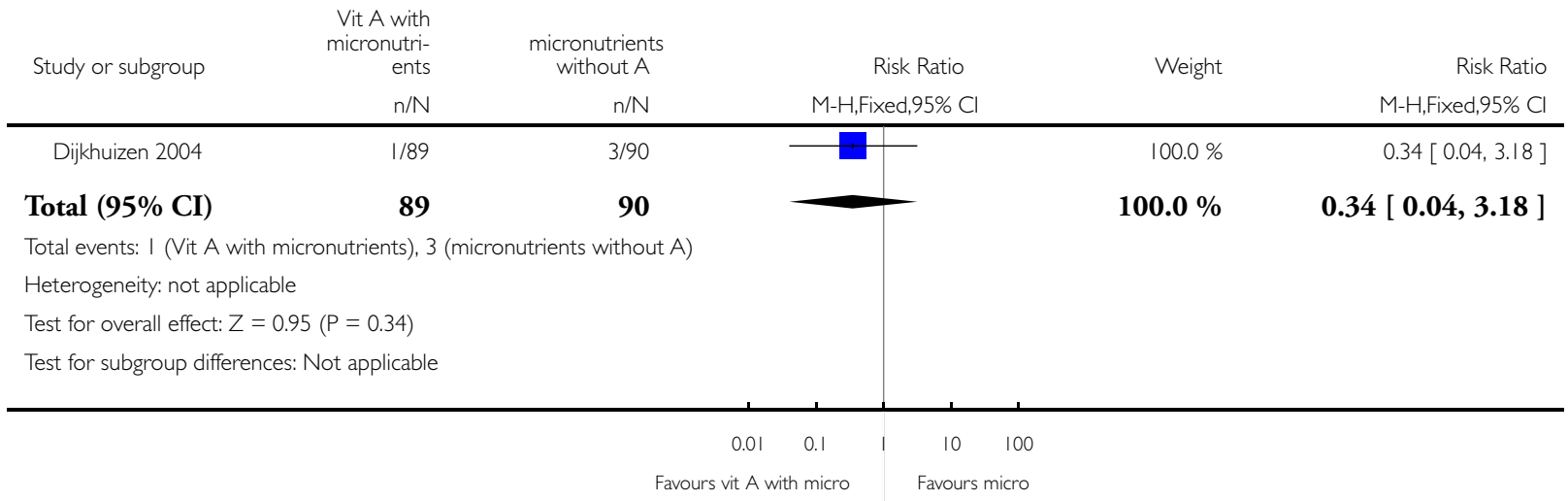

Analysis 3.12. Comparison 3 Vitamin A with other micronutrients versus micronutrient supplements without vitamin A, Outcome 12 Low birthweight.

Review: Vitamin A supplementation during pregnancy for maternal and newborn outcomes

Comparison: 3 Vitamin A with other micronutrients versus micronutrient supplements without vitamin $A$

Outcome: 12 Low birthweight

\begin{tabular}{|c|c|c|c|c|c|}
\hline \multirow[t]{2}{*}{ Study or subgroup } & $\begin{array}{r}\text { Vit A with } \\
\text { micronutri- } \\
\text { ents }\end{array}$ & $\begin{array}{l}\text { micronutrients } \\
\text { without A }\end{array}$ & Risk Ratio & \multirow[t]{2}{*}{ Weight } & \multirow{2}{*}{$\begin{array}{r}\text { Risk Ratio } \\
\text { M-H,Fixed,95\% Cl }\end{array}$} \\
\hline & $\mathrm{n} / \mathrm{N}$ & $\mathrm{n} / \mathrm{N}$ & M-H,Fixed,95\% Cl & & \\
\hline Kumwenda 2002 & $40 / 285$ & $65 / 309$ & & $100.0 \%$ & $0.67[0.47,0.96]$ \\
\hline Total (95\% CI) & 285 & 309 & $\bullet$ & $100.0 \%$ & $0.67[0.47,0.96]$ \\
\hline \multicolumn{6}{|c|}{ Total events: 40 (Vit A with micronutrients), 65 (micronutrients without A) } \\
\hline \multicolumn{6}{|c|}{ Heterogeneity: not applicable } \\
\hline \multicolumn{6}{|c|}{ Test for overall effect: $Z=2.21$ ( $P=0.027)$} \\
\hline Test for subgroup dif & Vot applicable & & & & \\
\hline
\end{tabular}

Favours vit A with micro Favours micro

Vitamin A supplementation during pregnancy for maternal and newborn outcomes (Review)

Copyright (c) 2015 The Cochrane Collaboration. Published by John Wiley \& Sons, Ltd. 


\section{Analysis 4.I. Comparison 4 Vitamin A alone versus placebo or no treatment (subgroups), Outcome I}

Perinatal mortality (infant mortality level).

Review: Vitamin A supplementation during pregnancy for maternal and newborn outcomes

Comparison: 4 Vitamin A alone versus placebo or no treatment (subgroups)

Outcome: I Perinatal mortality (infant mortality level)

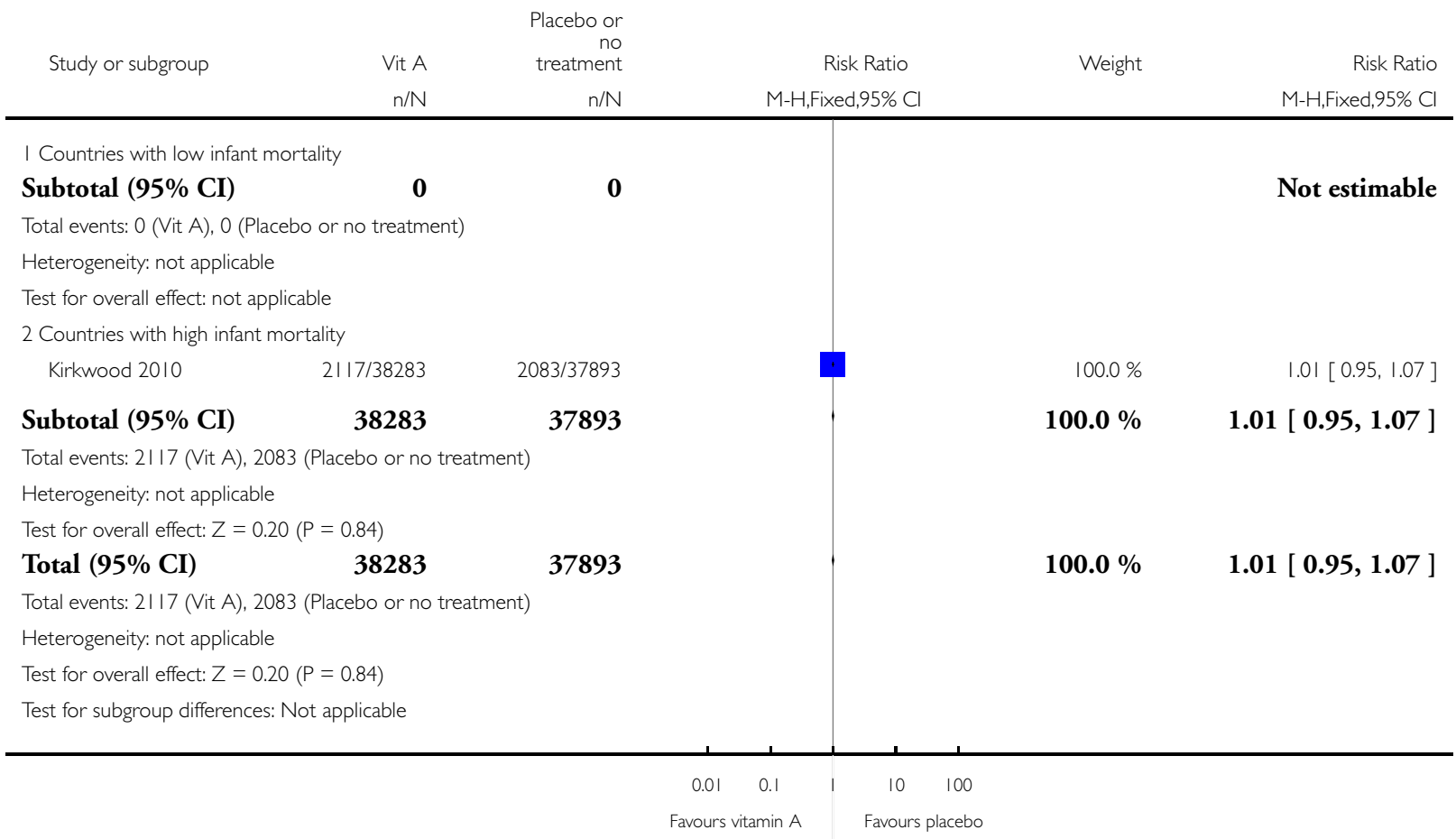


Analysis 4.3. Comparison 4 Vitamin A alone versus placebo or no treatment (subgroups), Outcome 3 Maternal mortality (maternal mortality level).

Review: Vitamin A supplementation during pregnancy for maternal and newborn outcomes

Comparison: 4 Vitamin A alone versus placebo or no treatment (subgroups)

Outcome: 3 Maternal mortality (maternal mortality level)

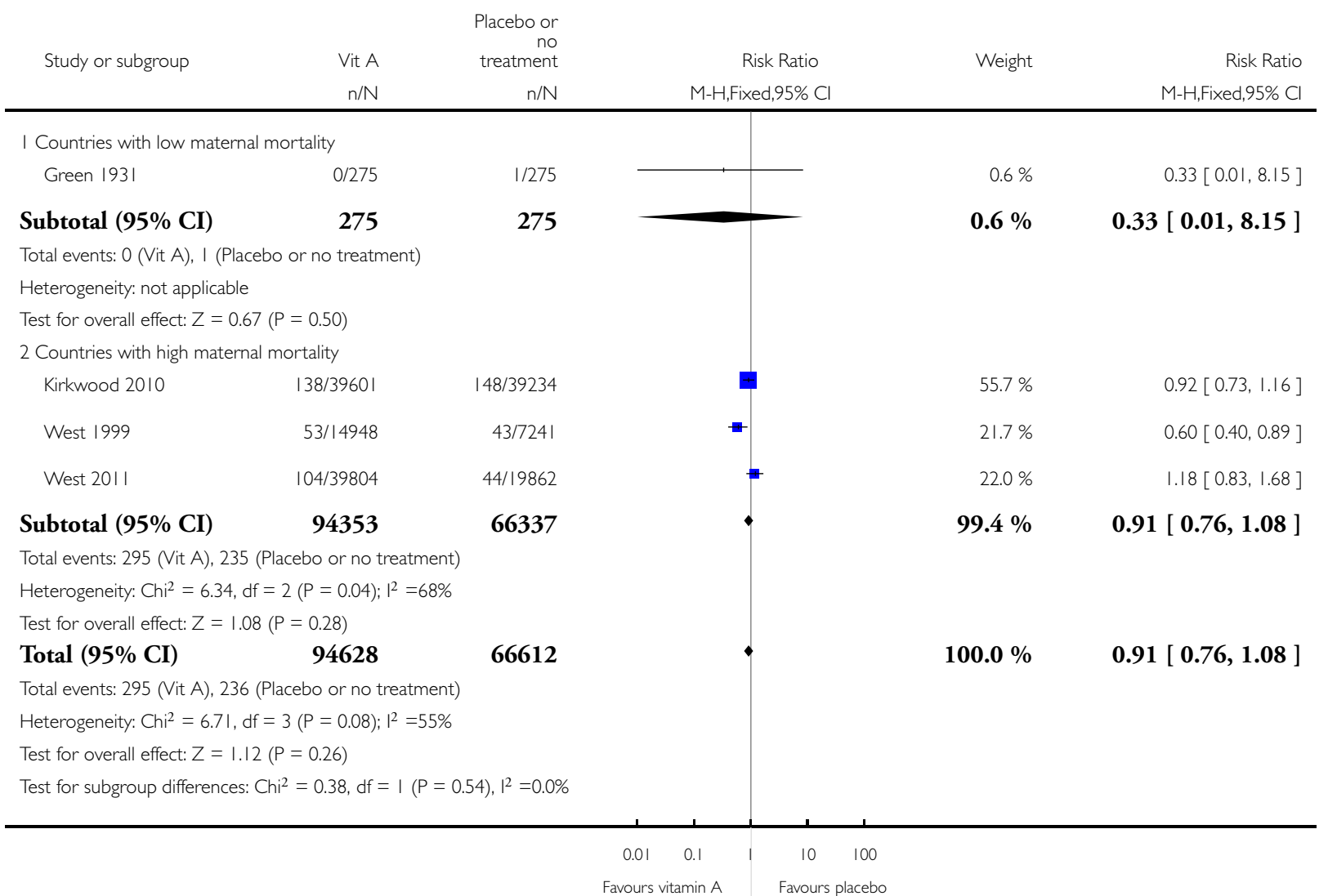


Analysis 4.4. Comparison 4 Vitamin A alone versus placebo or no treatment (subgroups), Outcome 4 Perinatal mortality (maternal mortality level).

Review: Vitamin A supplementation during pregnancy for maternal and newborn outcomes

Comparison: 4 Vitamin A alone versus placebo or no treatment (subgroups)

Outcome: 4 Perinatal mortality (maternal mortality level)

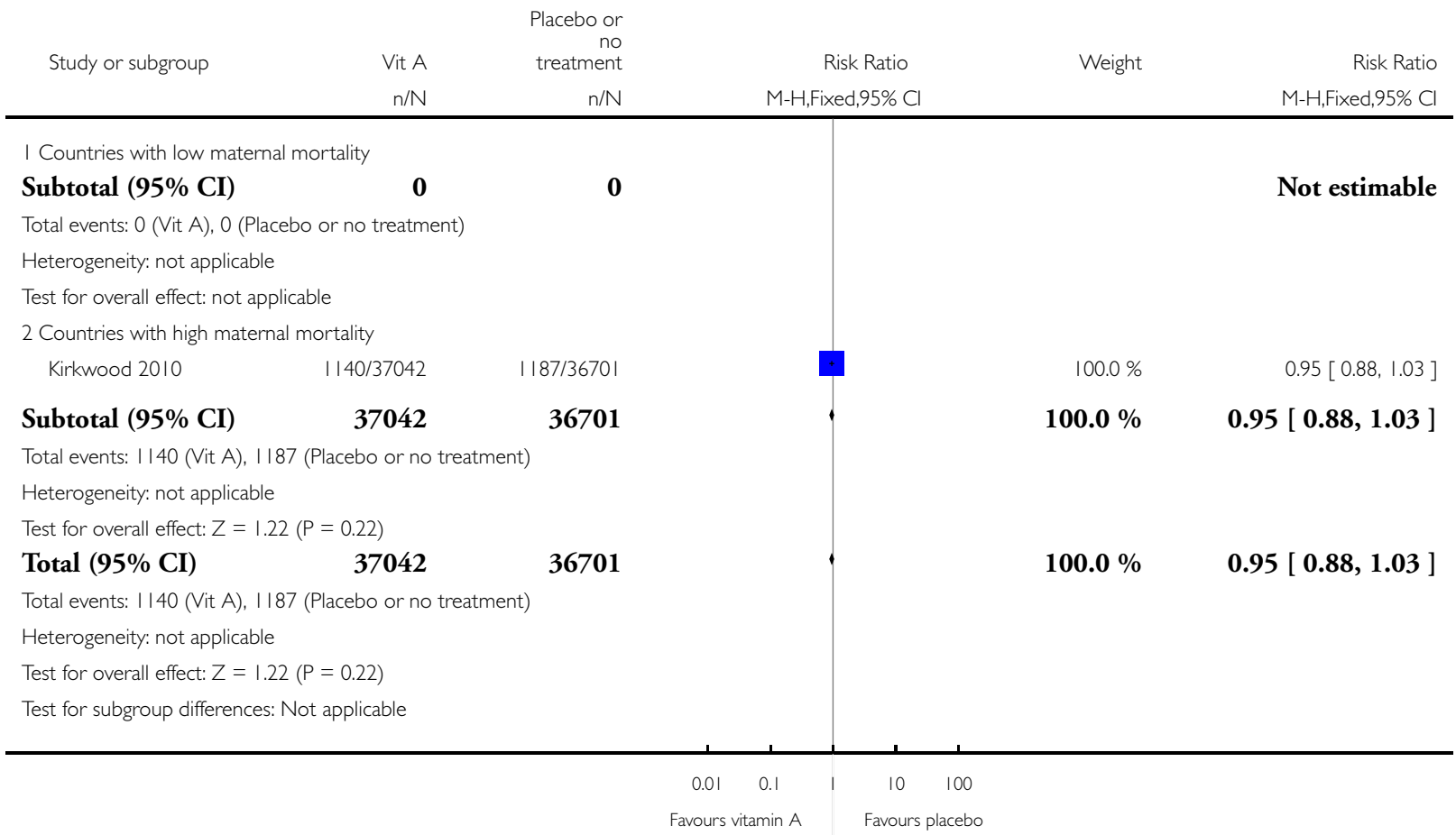


Analysis 4.5. Comparison 4 Vitamin A alone versus placebo or no treatment (subgroups), Outcome 5 Maternal mortality (prevalence of vitamin A deficiency).

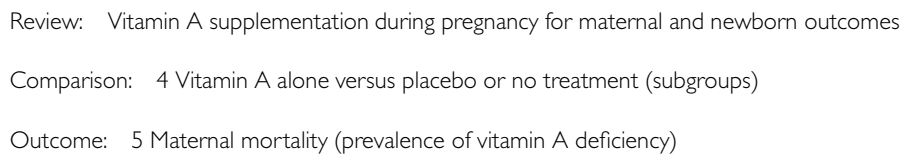

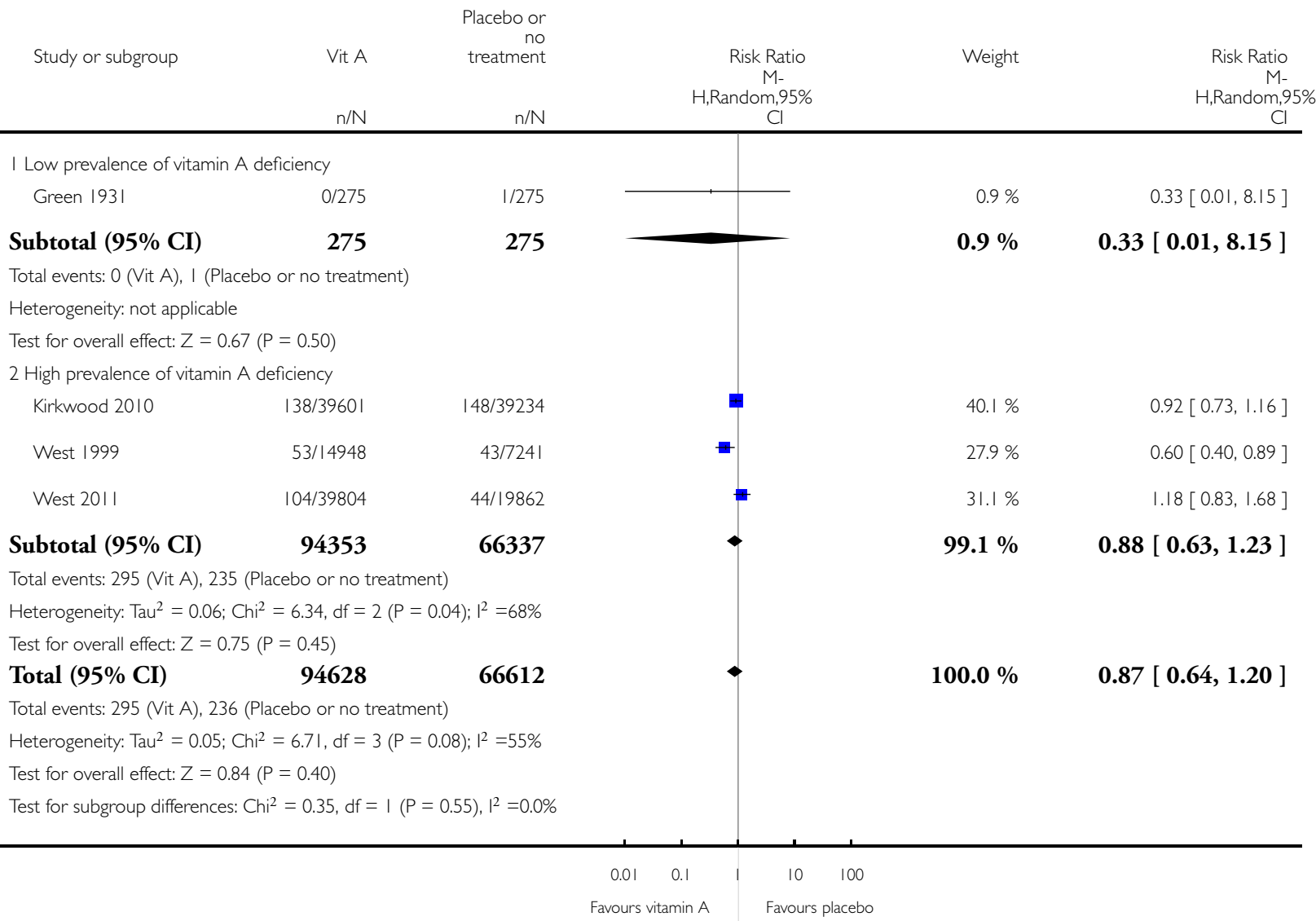


Analysis 4.6. Comparison 4 Vitamin A alone versus placebo or no treatment (subgroups), Outcome 6 Perinatal mortality (prevalence of vitamin A deficiency).

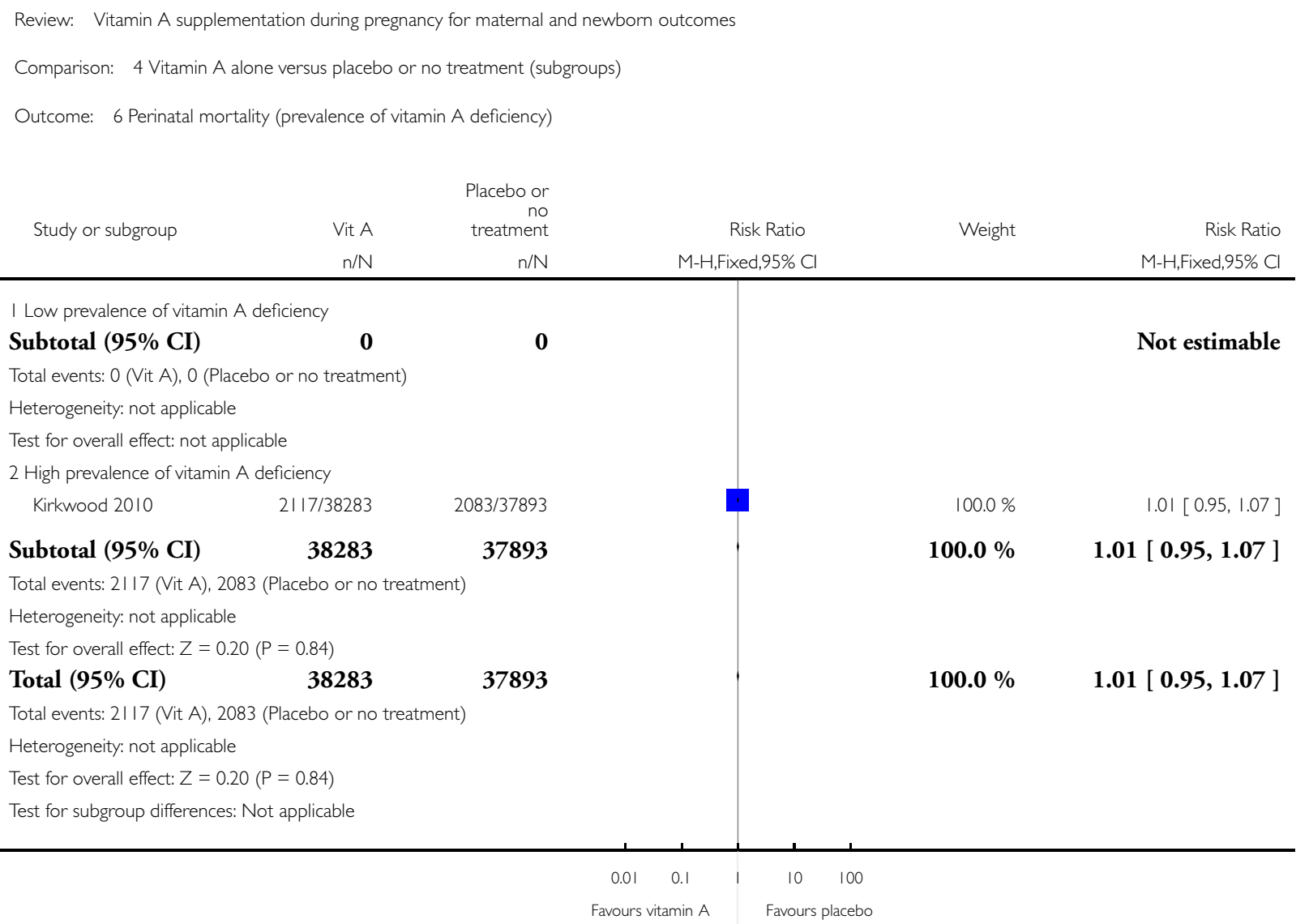




\section{Analysis 4.7. Comparison 4 Vitamin A alone versus placebo or no treatment (subgroups), Outcome 7 Maternal mortality (prevalence of HIV in the general population).}

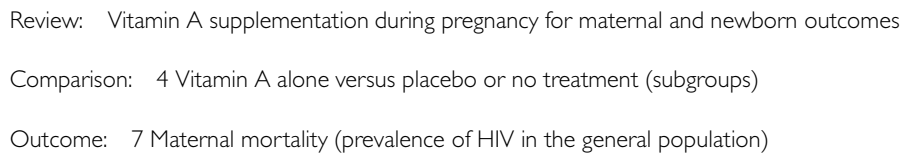

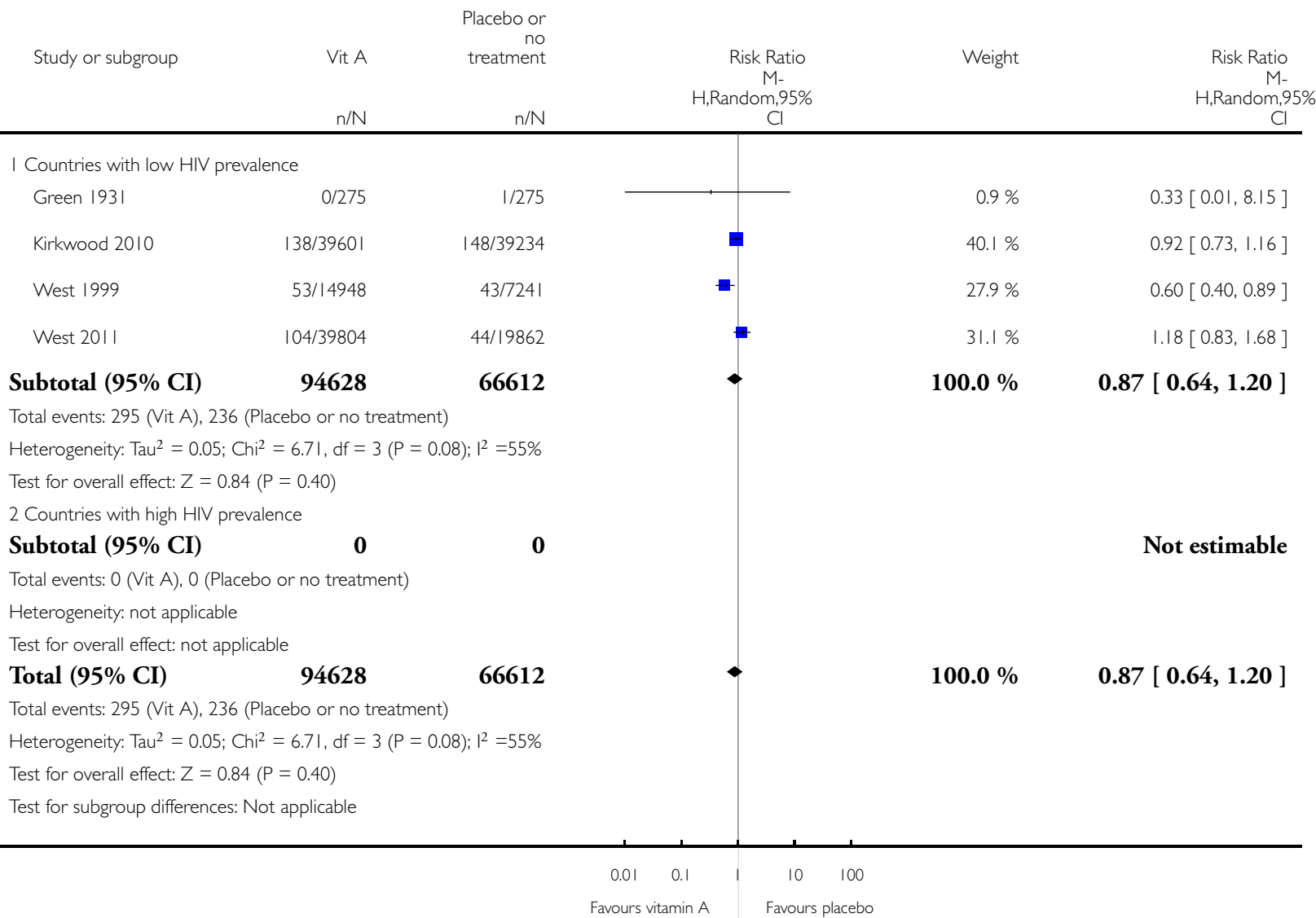


Analysis 4.8. Comparison 4 Vitamin A alone versus placebo or no treatment (subgroups), Outcome 8 Perinatal mortality (prevalence of HIV in the general population).

Review: Vitamin A supplementation during pregnancy for maternal and newborn outcomes

Comparison: 4 Vitamin A alone versus placebo or no treatment (subgroups)

Outcome: 8 Perinatal mortality (prevalence of HIV in the general population)

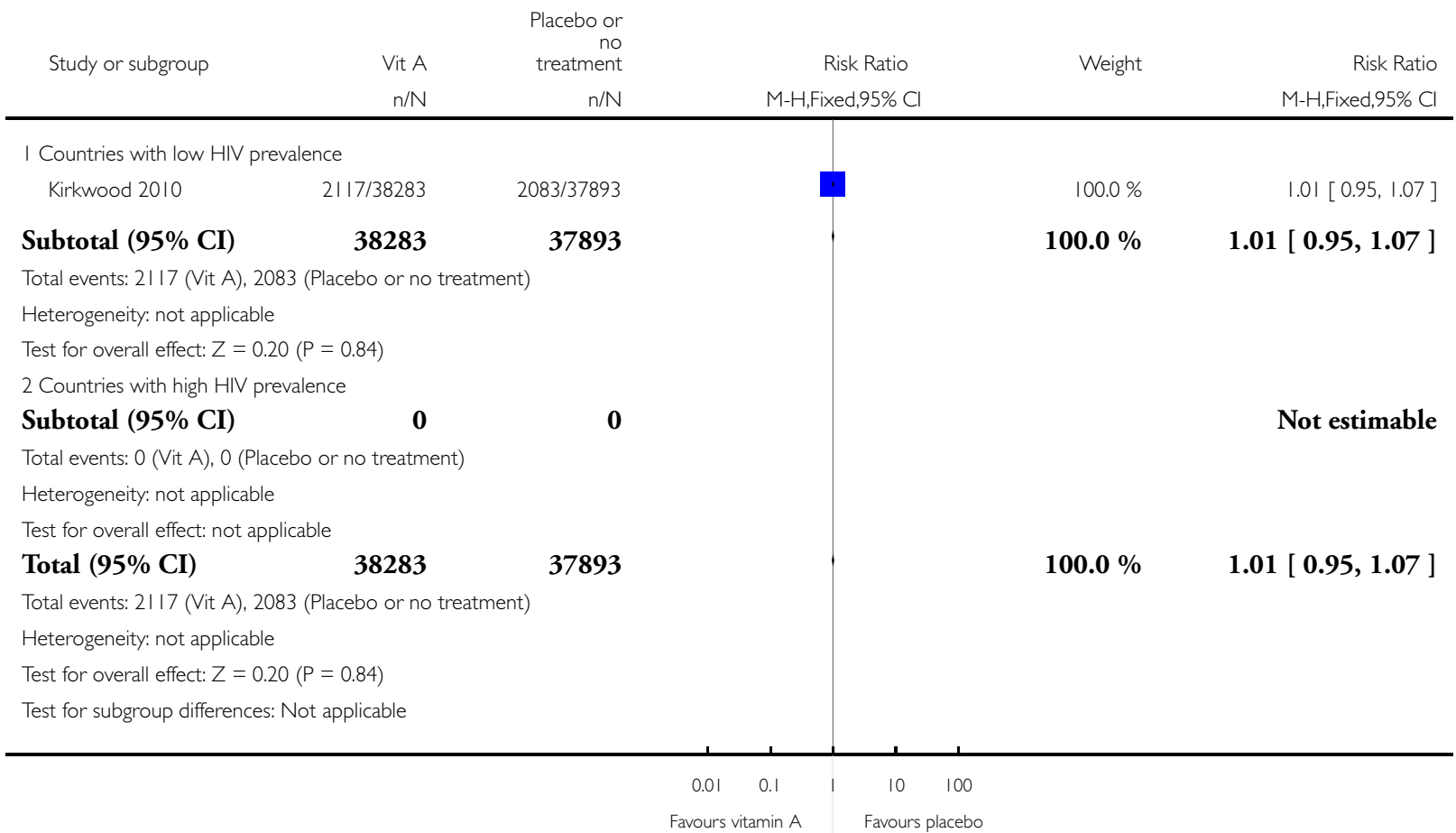


Analysis 4.9. Comparison 4 Vitamin A alone versus placebo or no treatment (subgroups), Outcome 9 Maternal mortality (dose).

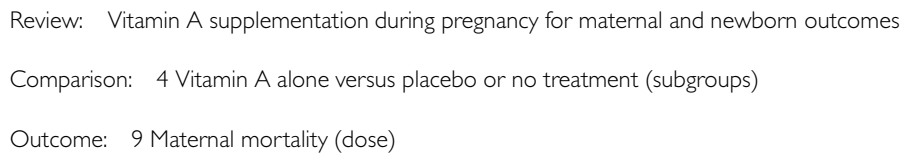

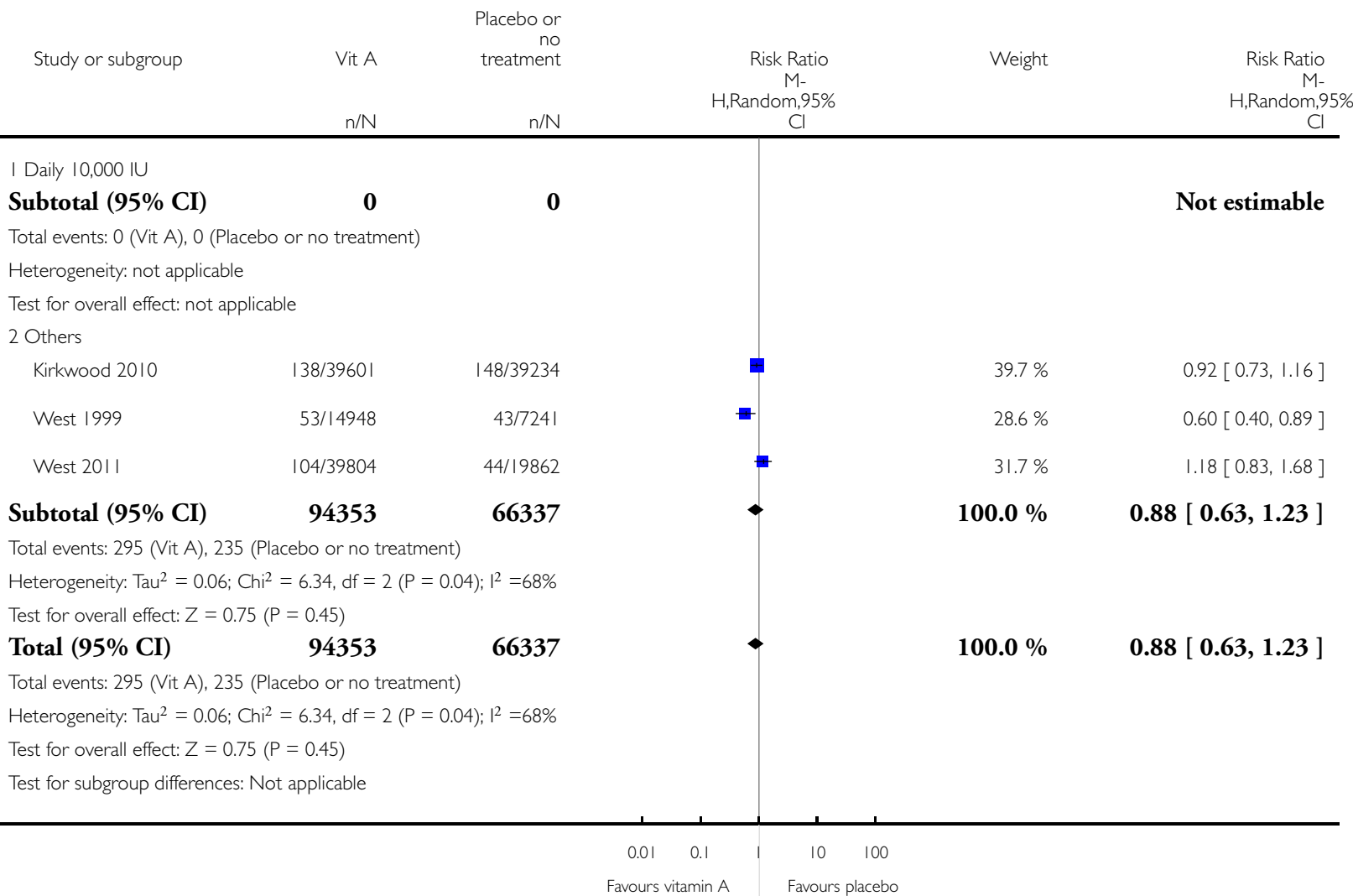


Analysis 4.10. Comparison 4 Vitamin A alone versus placebo or no treatment (subgroups), Outcome 10 Perinatal mortality (dose).

Review: Vitamin A supplementation during pregnancy for maternal and newborn outcomes

Comparison: 4 Vitamin A alone versus placebo or no treatment (subgroups)

Outcome: 10 Perinatal mortality (dose)

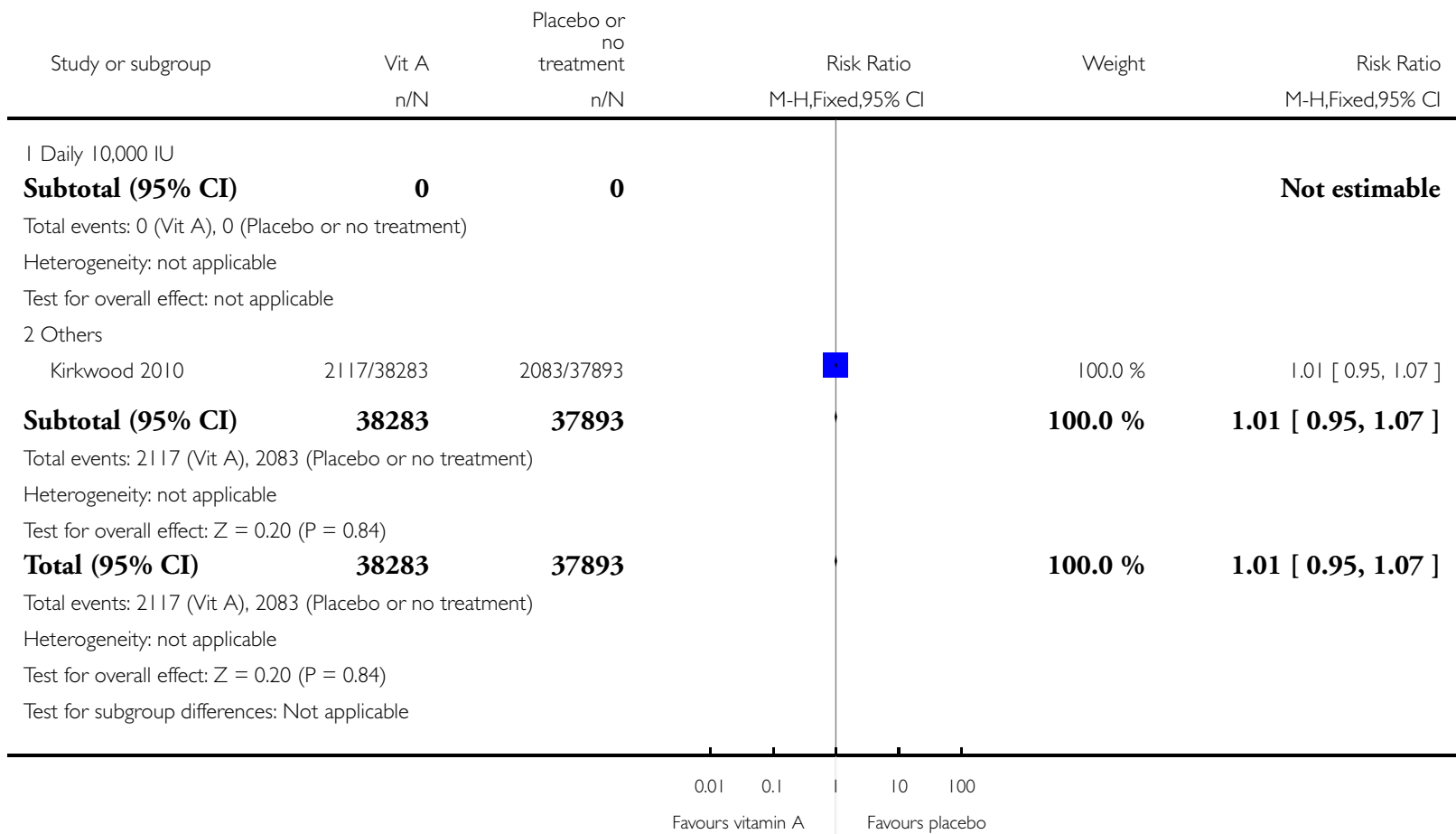


Analysis 4.I I. Comparison 4 Vitamin A alone versus placebo or no treatment (subgroups), Outcome I I Maternal mortality (regimen).

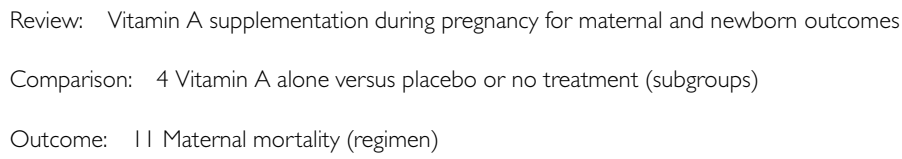

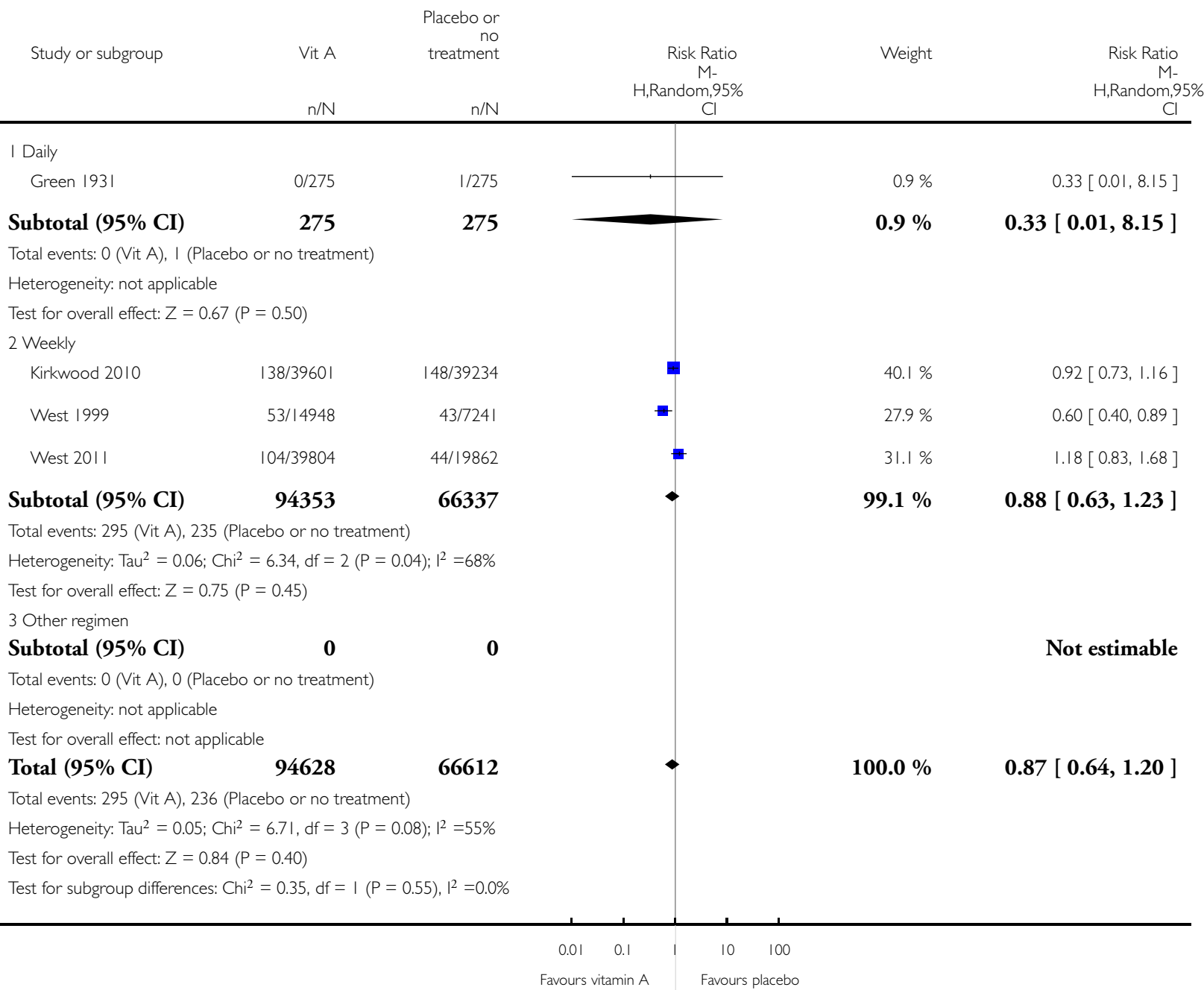


Analysis 4.12. Comparison 4 Vitamin A alone versus placebo or no treatment (subgroups), Outcome 12 Perinatal mortality (regimen).

Review: Vitamin A supplementation during pregnancy for maternal and newborn outcomes

Comparison: 4 Vitamin A alone versus placebo or no treatment (subgroups)

Outcome: 12 Perinatal mortality (regimen)

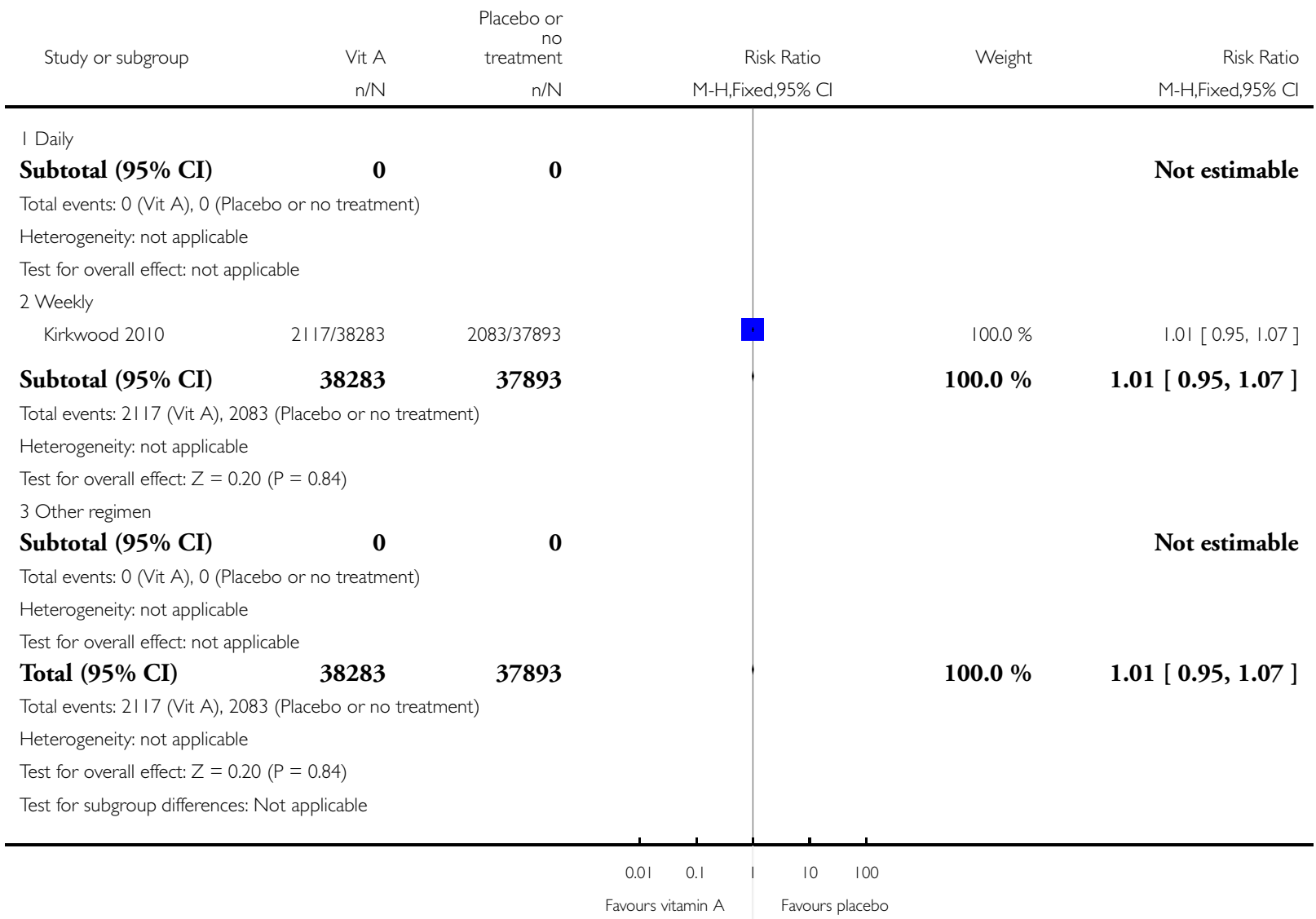


Analysis 4.13. Comparison 4 Vitamin A alone versus placebo or no treatment (subgroups), Outcome 13 Maternal mortality (duration of intervention).

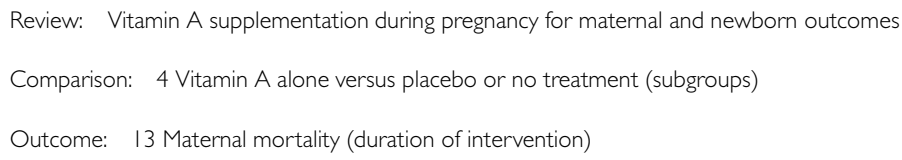

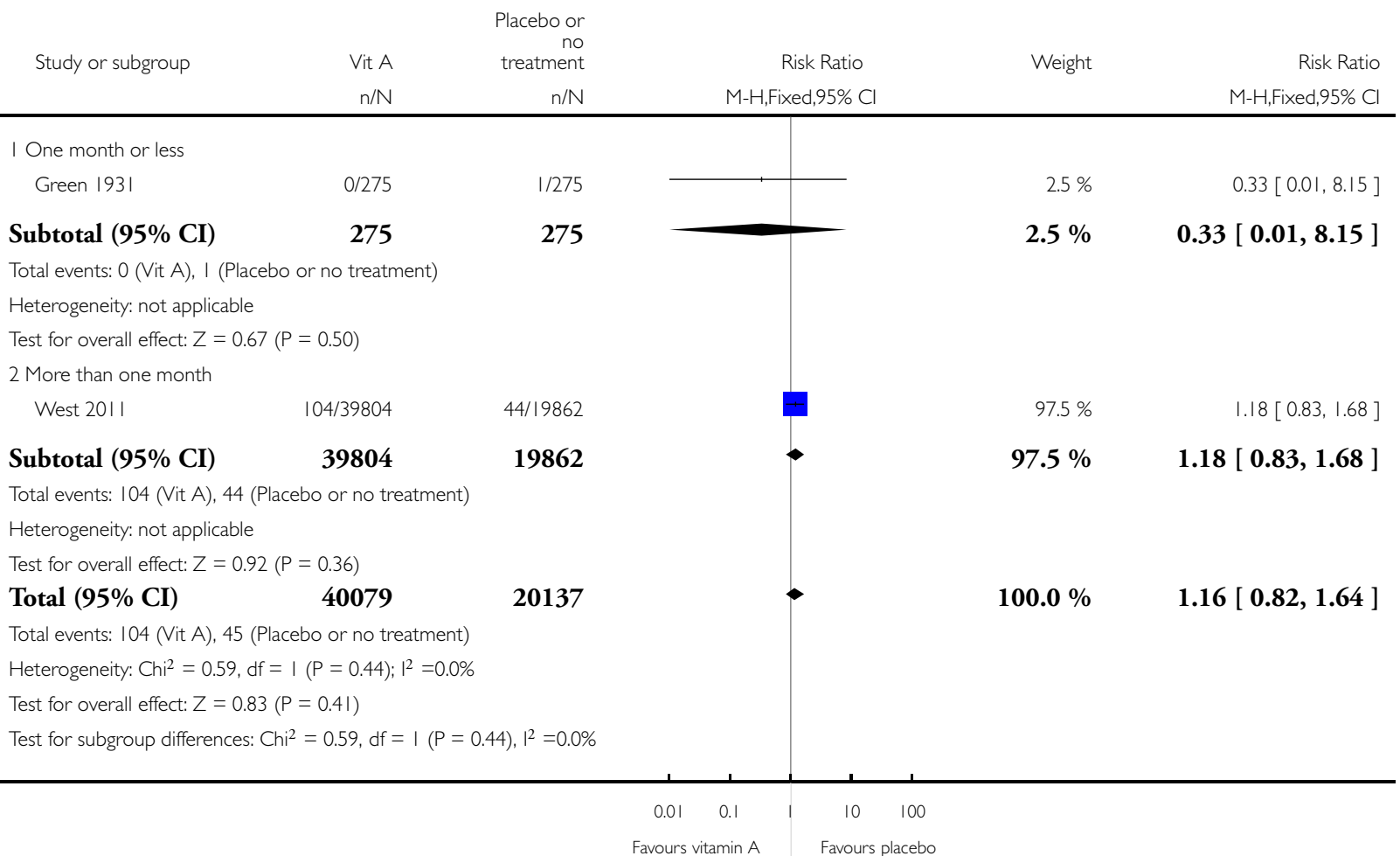


Analysis 4.15. Comparison 4 Vitamin A alone versus placebo or no treatment (subgroups), Outcome I5 Maternal mortality (trimester of pregnancy).

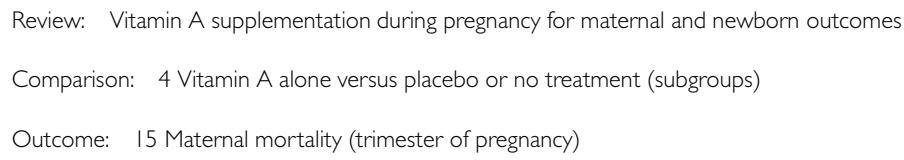

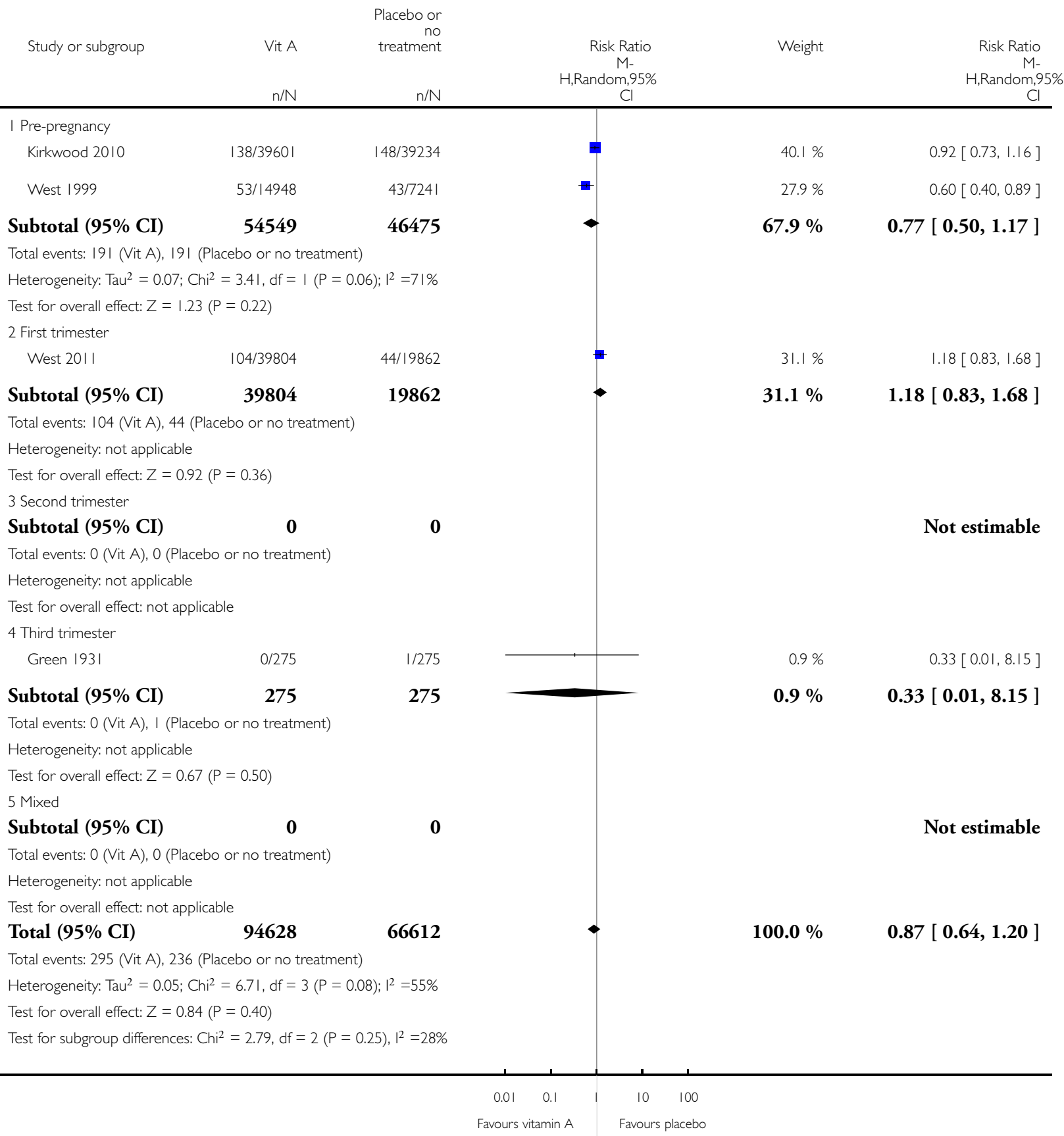




\section{Analysis 4.16. Comparison 4 Vitamin A alone versus placebo or no treatment (subgroups), Outcome 16 Perinatal mortality (trimester of pregnancy).}

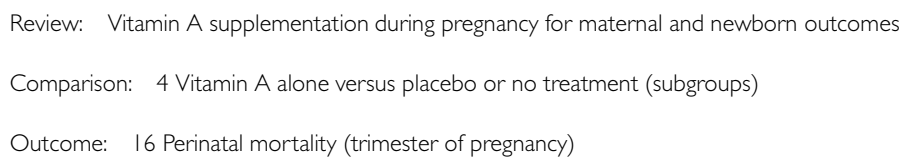




\section{Analysis 4.17. Comparison 4 Vitamin A alone versus placebo or no treatment (subgroups), Outcome I7}

Maternal mortality (randomisation).

Review: Vitamin A supplementation during pregnancy for maternal and newborn outcomes

Comparison: 4 Vitamin A alone versus placebo or no treatment (subgroups)

Outcome: 17 Maternal mortality (randomisation)

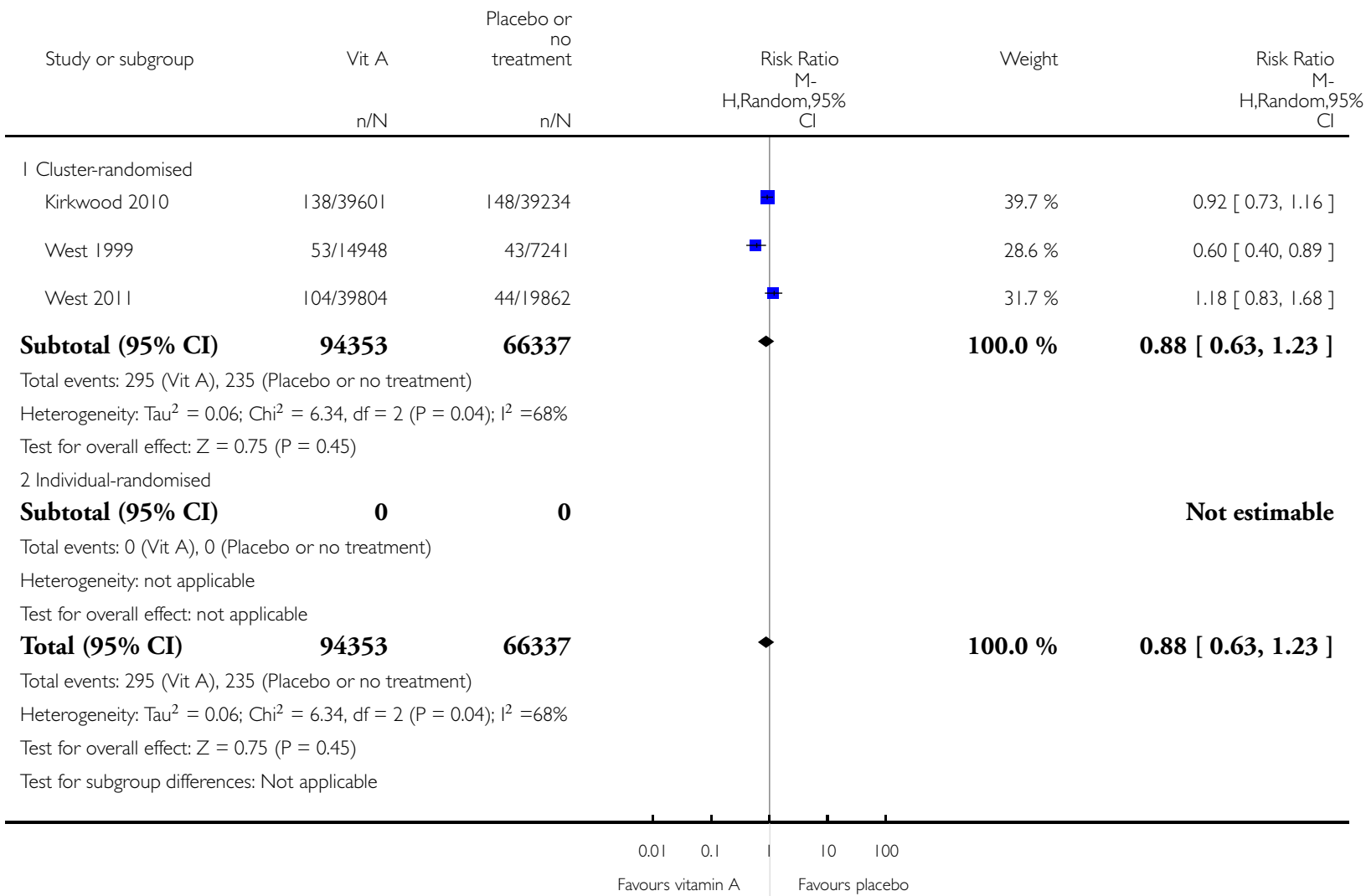


Analysis 4.18. Comparison 4 Vitamin A alone versus placebo or no treatment (subgroups), Outcome 18 Perinatal mortality (randomisation).

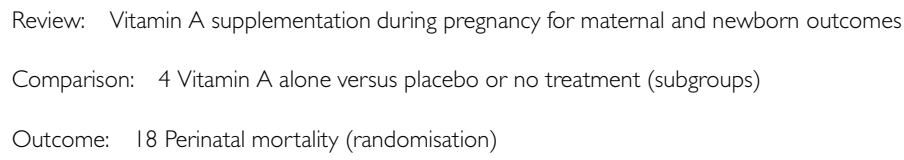

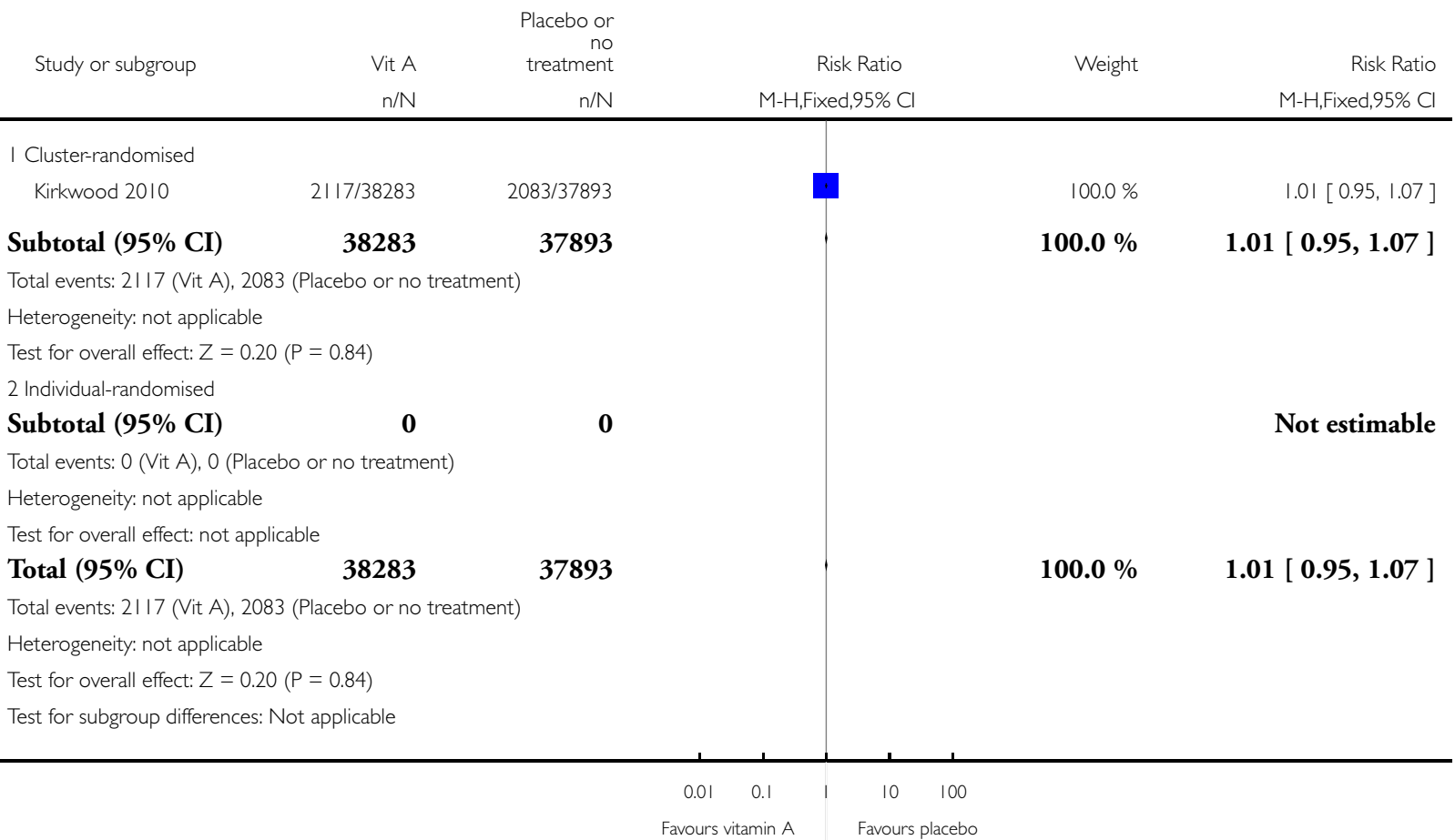


Analysis 6.2. Comparison 6 Vitamin A with other micronutrients versus micronutrient supplements without vitamin A (subgroups), Outcome 2 Perinatal mortality (infant mortality level).

Review: Vitamin A supplementation during pregnancy for maternal and newborn outcomes

Comparison: 6 Vitamin A with other micronutrients versus micronutrient supplements without vitamin A (subgroups)

Outcome: 2 Perinatal mortality (infant mortality level)

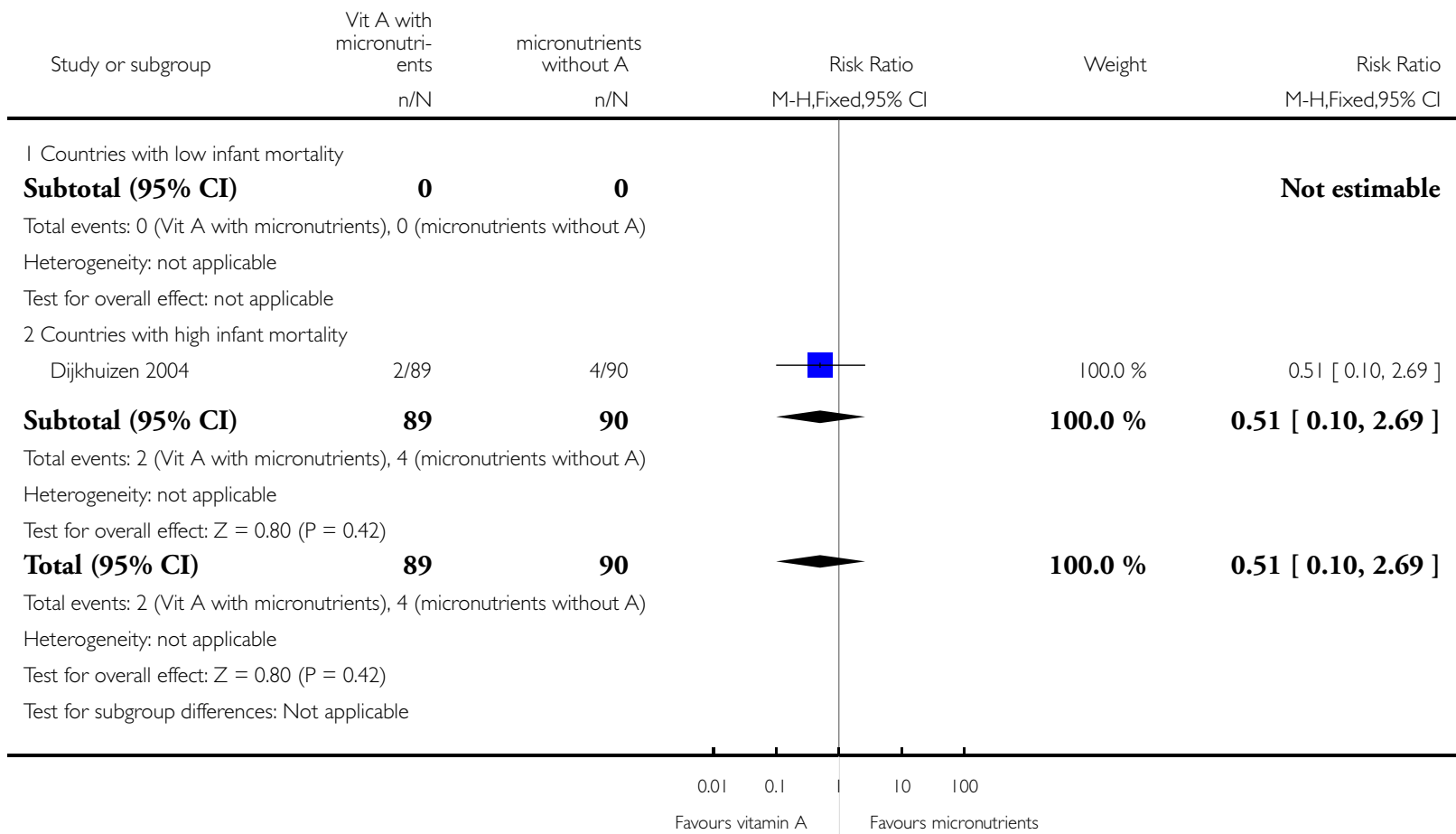


Analysis 6.4. Comparison 6 Vitamin A with other micronutrients versus micronutrient supplements without vitamin A (subgroups), Outcome 4 Perinatal mortality (maternal mortality level).

Review: Vitamin A supplementation during pregnancy for maternal and newborn outcomes

Comparison: 6 Vitamin A with other micronutrients versus micronutrient supplements without vitamin A (subgroups)

Outcome: 4 Perinatal mortality (maternal mortality level)

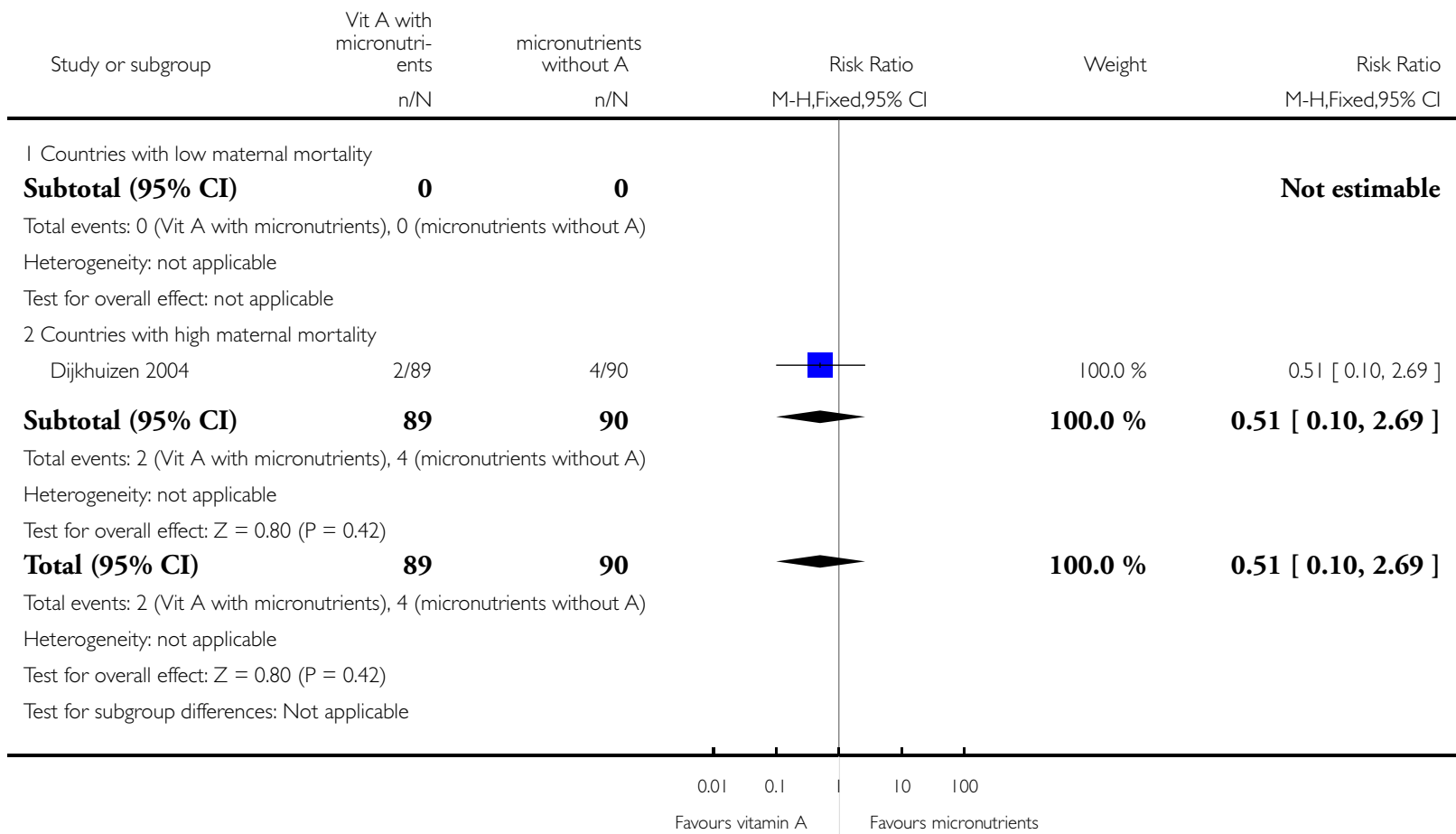


Analysis 6.5. Comparison 6 Vitamin A with other micronutrients versus micronutrient supplements without vitamin A (subgroups), Outcome 5 Maternal mortality (prevalence of vitamin A deficiency).

Review: Vitamin A supplementation during pregnancy for maternal and newborn outcomes

Comparison: 6 Vitamin A with other micronutrients versus micronutrient supplements without vitamin A (subgroups)

Outcome: 5 Maternal mortality (prevalence of vitamin A deficiency)

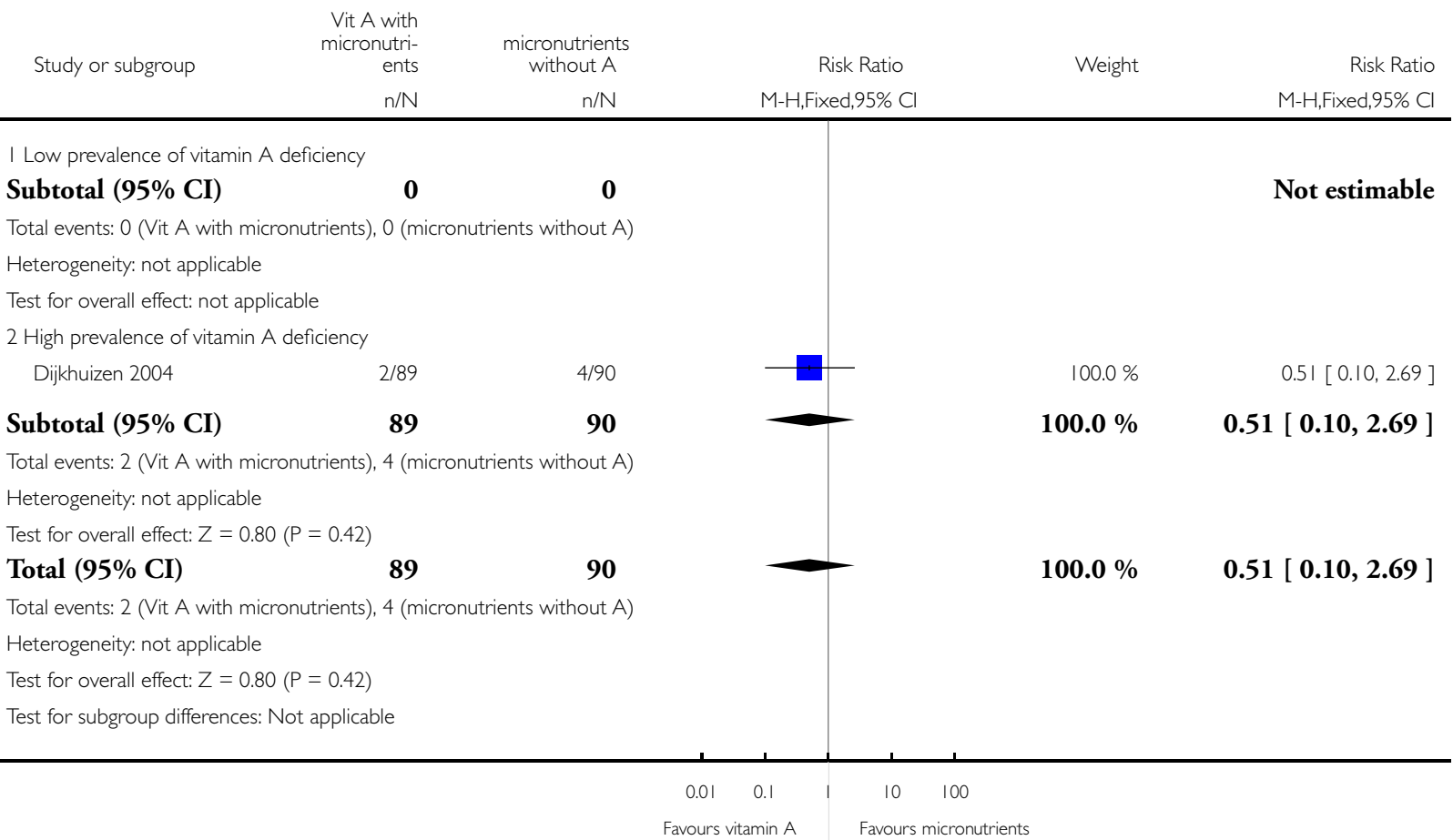


Analysis 6.6. Comparison 6 Vitamin A with other micronutrients versus micronutrient supplements without vitamin A (subgroups), Outcome 6 Perinatal mortality (prevalence of vitamin A deficiency).

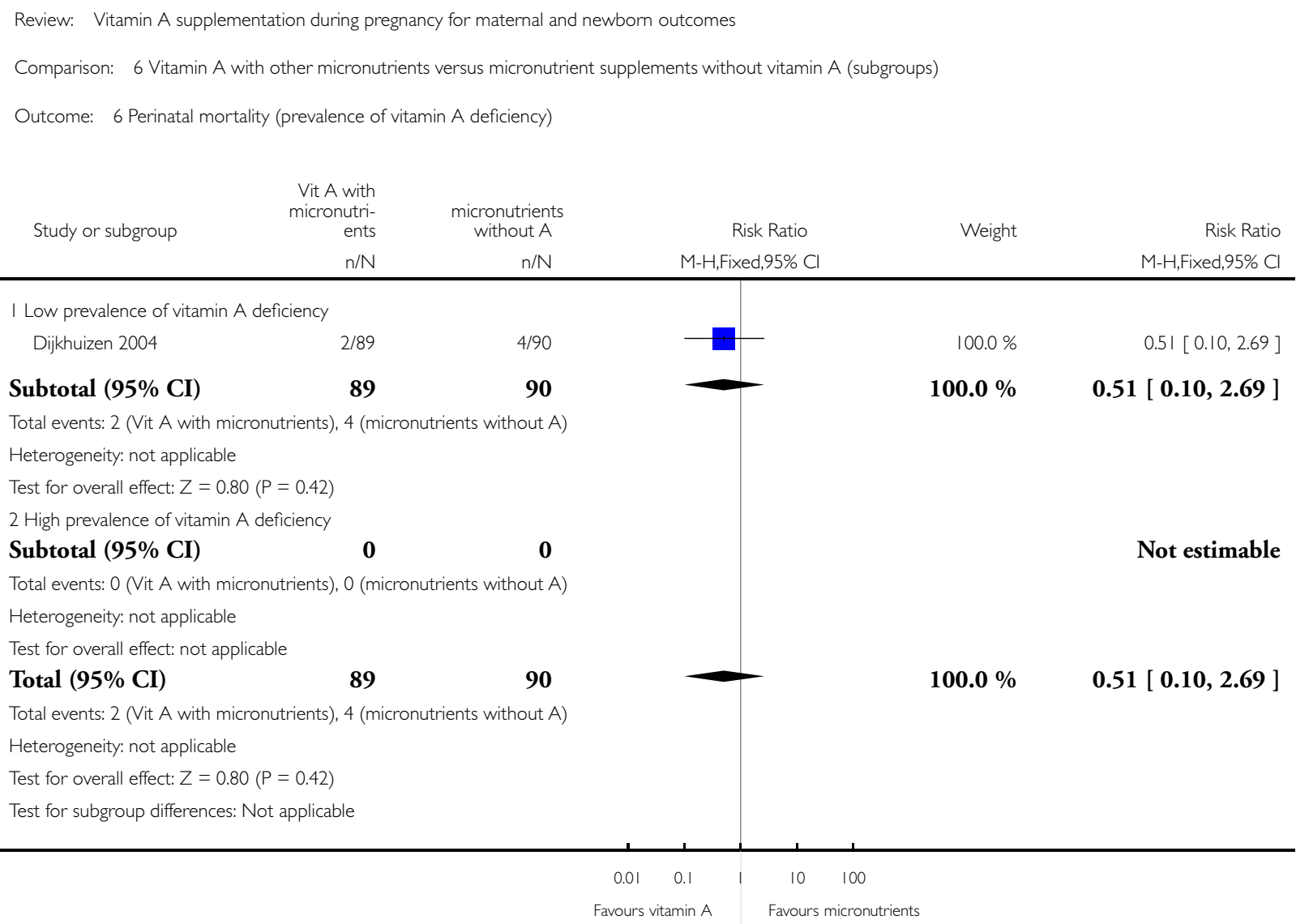


Analysis 6.8. Comparison 6 Vitamin A with other micronutrients versus micronutrient supplements without vitamin A (subgroups), Outcome 8 Perinatal mortality (prevalence of HIV in the general population).

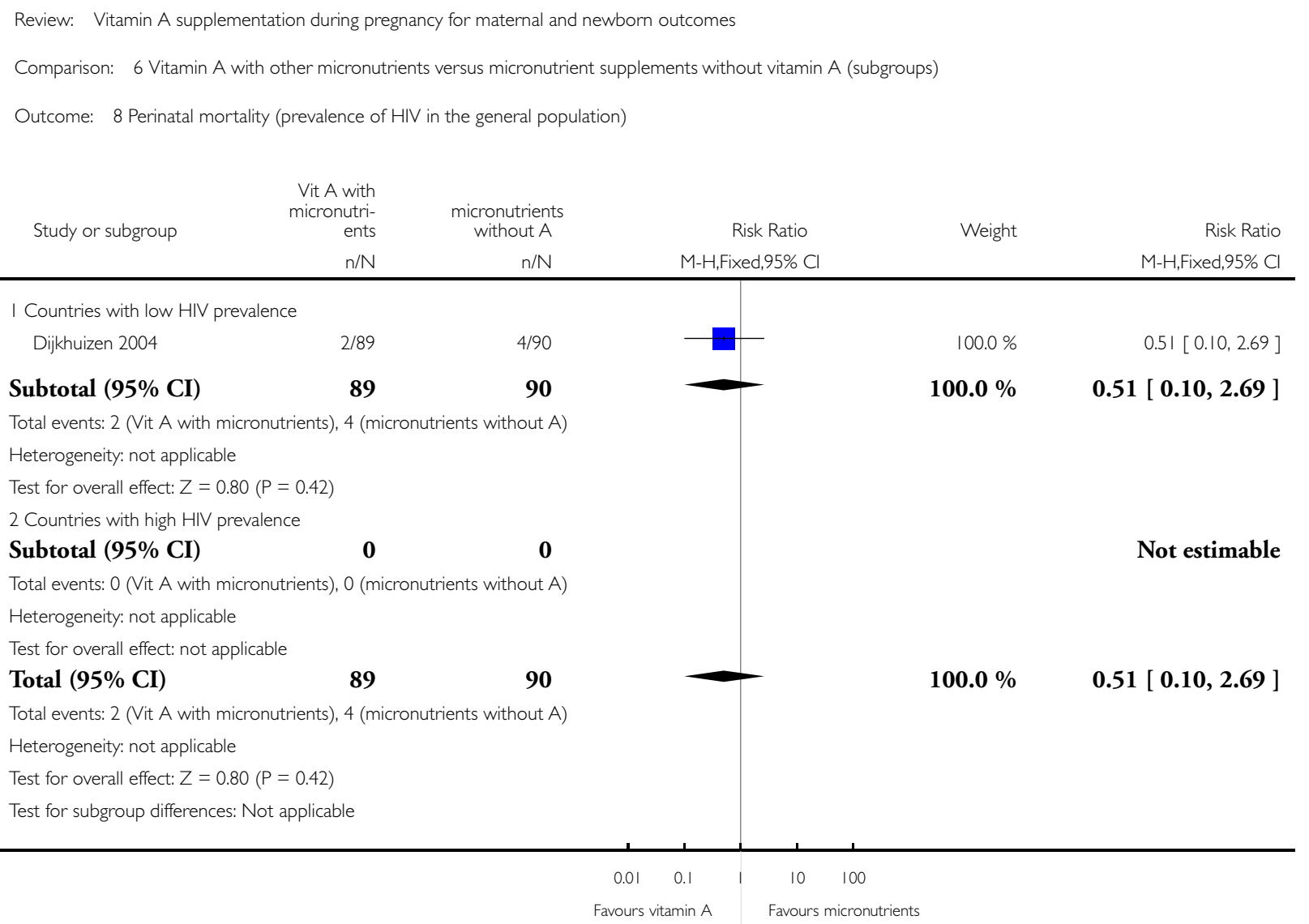


Analysis 6.10. Comparison 6 Vitamin A with other micronutrients versus micronutrient supplements without vitamin A (subgroups), Outcome 10 Perinatal mortality (dose).

Review: Vitamin A supplementation during pregnancy for maternal and newborn outcomes

Comparison: 6 Vitamin A with other micronutrients versus micronutrient supplements without vitamin A (subgroups)

Outcome: 10 Perinatal mortality (dose)

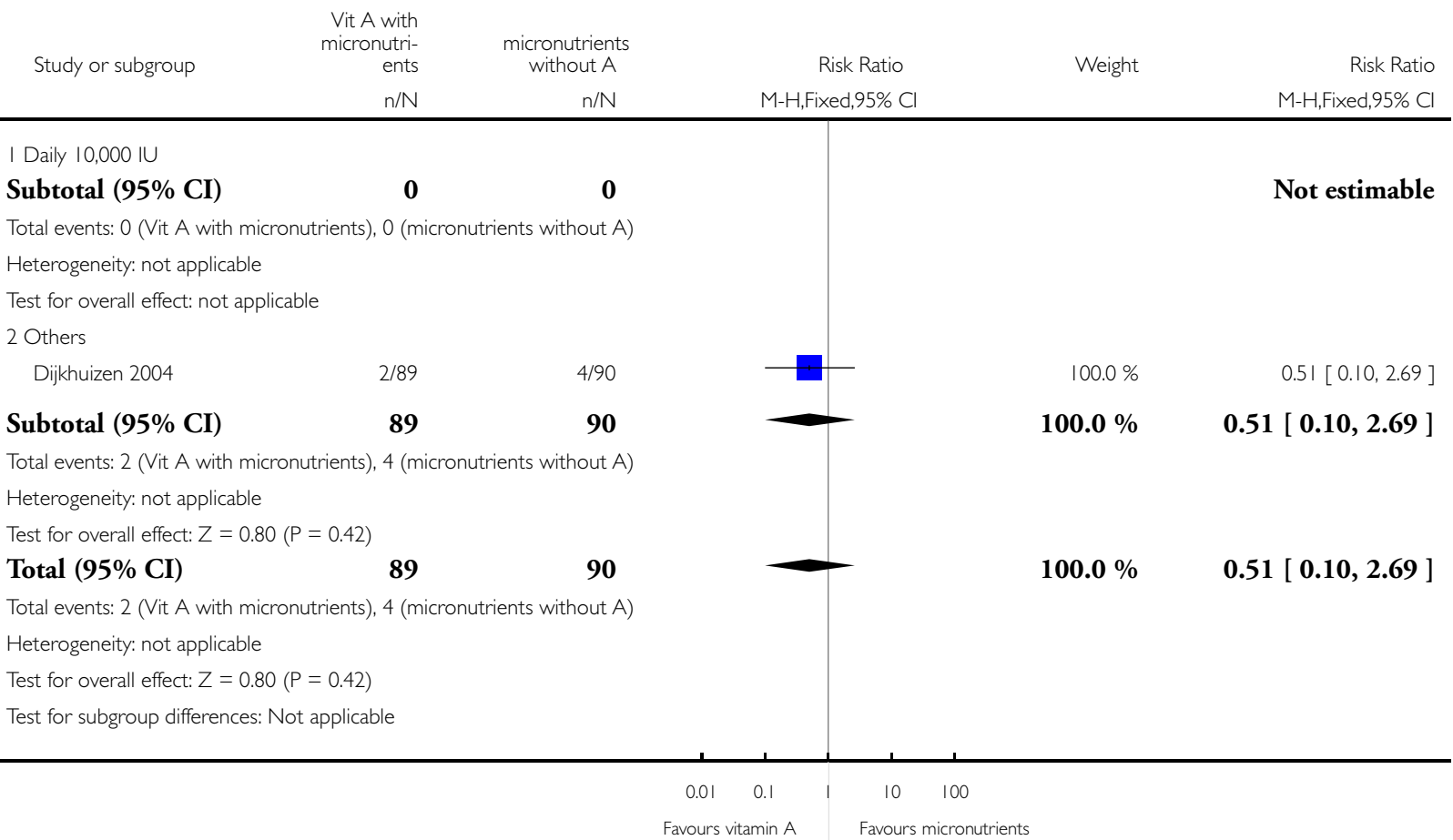


Analysis 6.12. Comparison 6 Vitamin A with other micronutrients versus micronutrient supplements without vitamin A (subgroups), Outcome 12 Perinatal mortality (regimen).

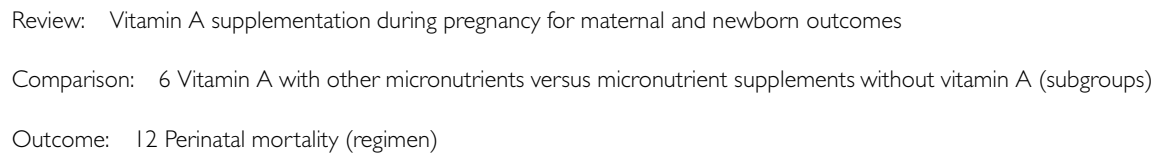

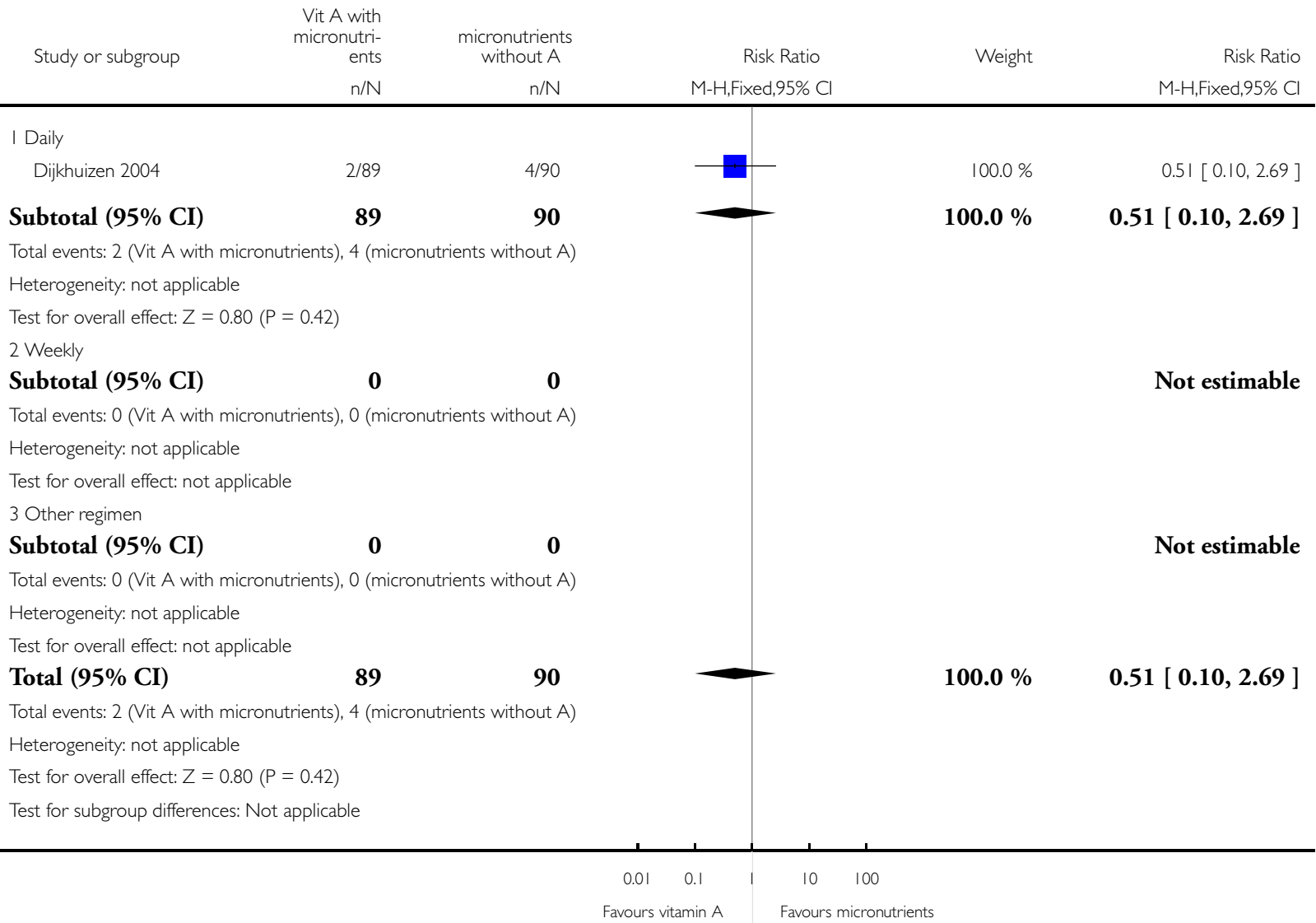


Analysis 6.16. Comparison 6 Vitamin A with other micronutrients versus micronutrient supplements without vitamin A (subgroups), Outcome 16 Perinatal mortality (trimester of pregnancy).

Review: Vitamin A supplementation during pregnancy for maternal and newborn outcomes

Comparison: 6 Vitamin A with other micronutrients versus micronutrient supplements without vitamin A (subgroups)

Outcome: 16 Perinatal mortality (trimester of pregnancy)

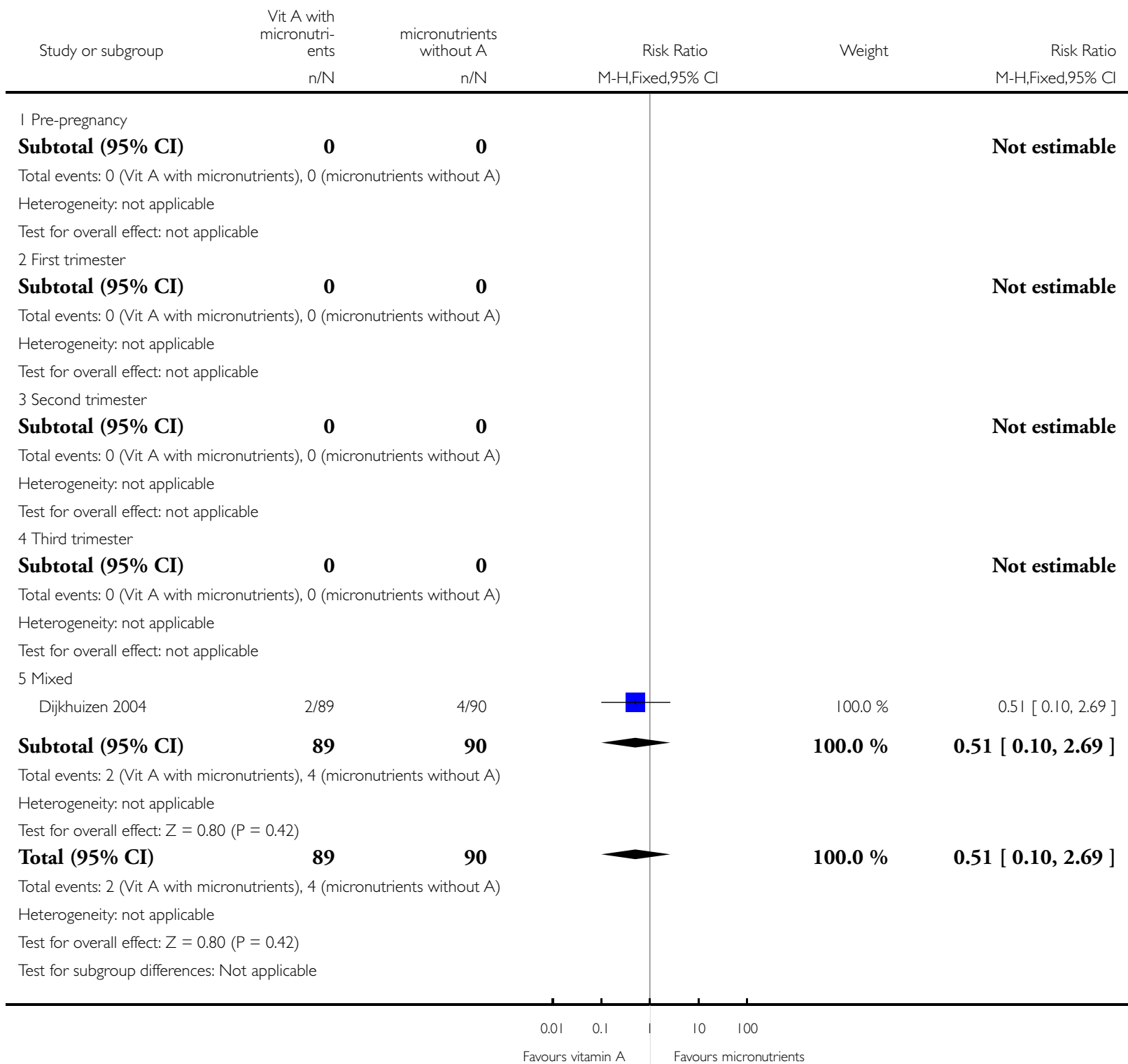


Analysis 6.18. Comparison 6 Vitamin A with other micronutrients versus micronutrient supplements without vitamin A (subgroups), Outcome 18 Perinatal mortality (randomisation).

Review: Vitamin A supplementation during pregnancy for maternal and newborn outcomes

Comparison: 6 Vitamin A with other micronutrients versus micronutrient supplements without vitamin A (subgroups)

Outcome: 18 Perinatal mortality (randomisation)

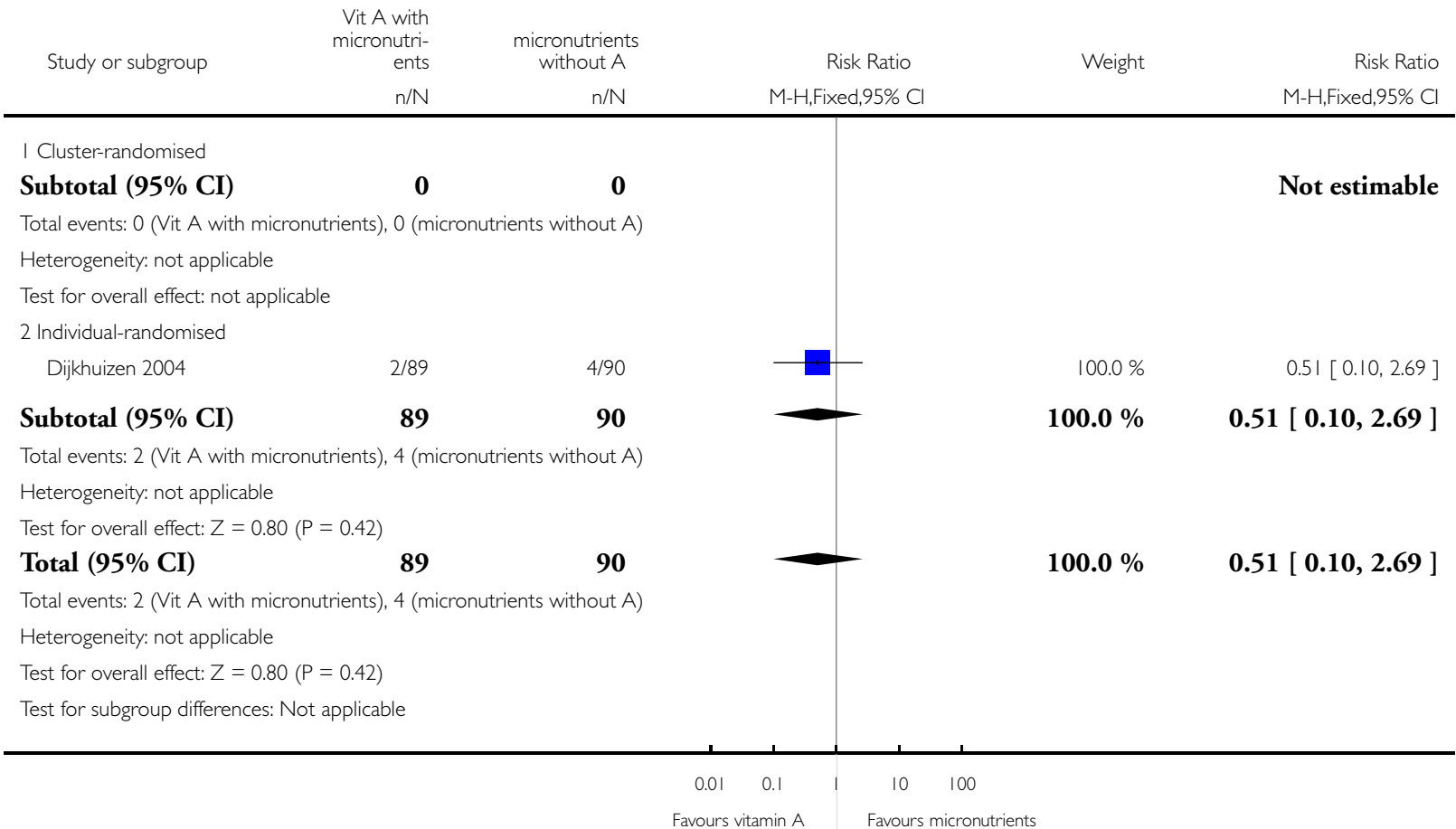

\section{ADDITIONAL TABLES}

Table 1. Retinol supplementation to vitamin A conversion table

\begin{tabular}{l|l}
\hline Retinol supplementation in mcg & Vitamin A in IU \\
\hline 1 & 3.33 \\
\hline 2 & 6.66 \\
\hline 3 & 9.99 \\
\hline
\end{tabular}

IU: international units 
Table 2. Serum retinol conversion table

\begin{tabular}{ll} 
Serum retinol $\mathbf{~ m c g} / \mathbf{d L}$ & Serum retinol $\mathbf{~ m c ~} \mathbf{~ m o l} / \mathbf{L}$ \\
\hline 10 & 0.35 \\
\hline 20 & 0.7 \\
\hline 30 & 1.05 \\
\hline
\end{tabular}

\section{WHAT'S NEW}

Last assessed as up-to-date: 30 March 2015.

\begin{tabular}{l|l|l}
\hline Date & Event & Description \\
\hline 30 March 2015 & New search has been performed & $\begin{array}{l}\text { Search updated. Methods updated. 'Summary of find- } \\
\text { ings' tables have been incorporated for this update }\end{array}$ \\
\hline 30 March 2015 & New citation required but conclusions have not changed & $\begin{array}{l}\text { Three new studies have been included in this update } \\
\text { (Hakimi 1999; Sun 2010; West 2011). The review now } \\
\text { includes a total of 19 studies. The conclusions remain } \\
\text { the same }\end{array}$ \\
\hline
\end{tabular}

\section{H I S T O R Y}

Protocol first published: Issue 9, 2010

Review first published: Issue 11, 2010

\begin{tabular}{|c|c|c|}
\hline Date & Event & Description \\
\hline 15 February 2011 & Amended & $\begin{array}{l}\text { Authors of the Kirkwood } 2010 \text { trial provided additional information about the loss to follow up } \\
\text { figure for the pregnancy-related mortality analysis, which was } 8 \% \text { and not } 44 \%\end{array}$ \\
\hline
\end{tabular}




\section{CONTRIBUTIONSOFAUTHORS}

M McCauley and M Othman carried out the data extraction, which was checked by N van den Broek and L Dou. L Dou performed the statistical analysis and contributed to the text of the review. This review was written by M McCauley, adapted from the original protocol for van den Broek 2010 and reviewed at draft and final manuscript by $\mathrm{N}$ van den Broek.

\section{DECLARATIONSOF INTEREST}

$\mathrm{N}$ van den Broek is an investigator in the included trial van den Broek 2006 and did not perform any assessment or data extraction for this trial.

\section{SOURCES OF SUPPORT}

\section{Internal sources}

- Liverpool School of Tropical Medicine, UK.

- HRP-UNDP/UNFPA/WHO/World Bank Special Programme in Human Reproduction, Geneva, Switzerland.

- Department of Obstetrics and Gynaecology, University of Geneva, Switzerland.

\section{External sources}

- Department of Nutrition for Health and Development, World Health Organization, Switzerland. Provided funding for the preparation of this review.

- UNDP/UNFPA/UNICEF/WHO/World Bank Special Programme of Research, Development and Research Training in Human Reproduction (HRP), Department of Reproductive Health and Research (RHR), World Health Organization, Switzerland.

\section{DIFFERENCES BETWEEN PROTOCOLANDREVIEW}

Methods updated to current standard text of Cochrane Pregnancy and Childbirth. 'Summary of findings' tables have been incorporated for the 2015 update.

\section{INDEX TERMS}

\section{Medical Subject Headings (MeSH)}

Anemia [prevention \& control]; Infant Mortality; Maternal Mortality; Night Blindness [drug therapy]; Pregnancy Complications [*drug therapy]; Pregnancy Complications, Infectious [drug therapy]; Vitamin A [*administration \& dosage]; Vitamin A Deficiency [*drug therapy]; Vitamins [ ${ }^{*}$ administration \& dosage]

\section{MeSH check words}

Female; Humans; Infant, Newborn; Pregnancy 